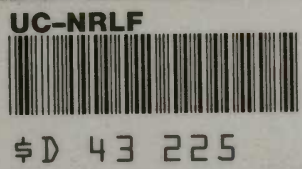



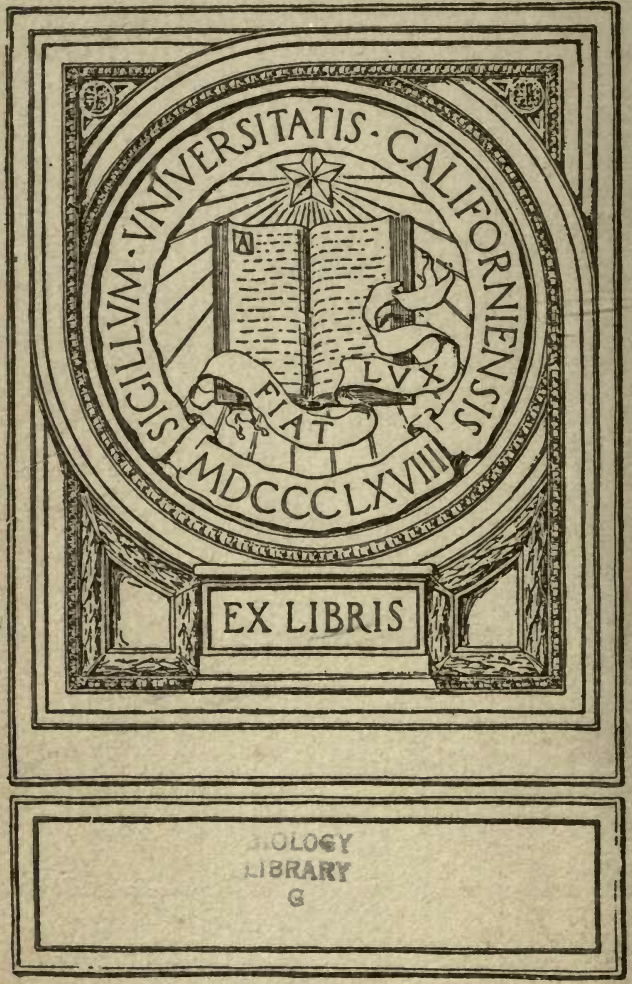
I.

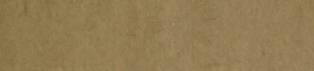

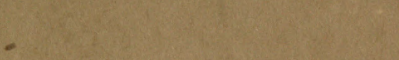

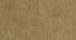

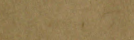

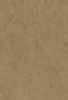

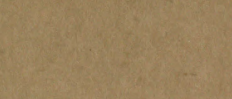

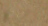

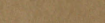

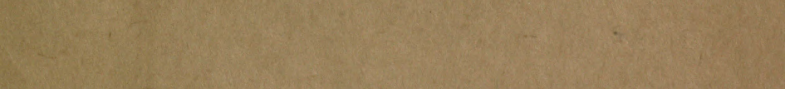

(3)

(1)

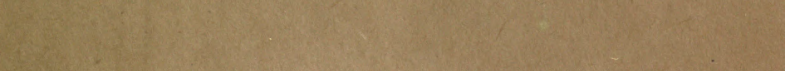

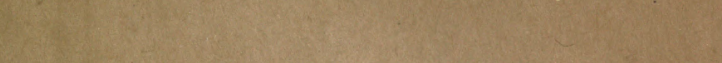

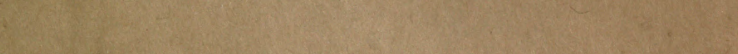
15:

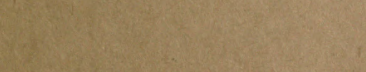

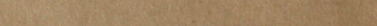

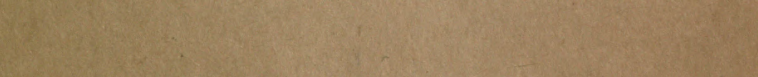
6.

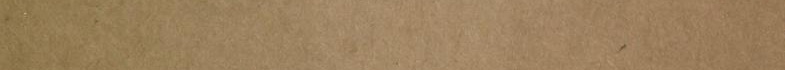

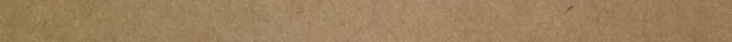

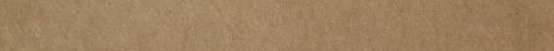

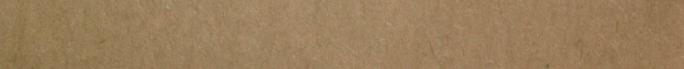

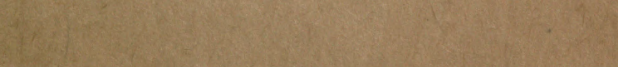
W. 6. P.

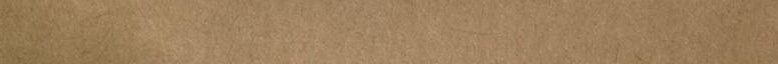
3.

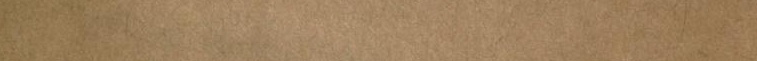

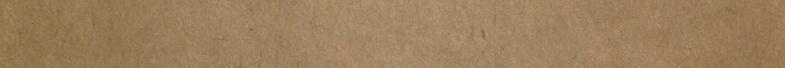

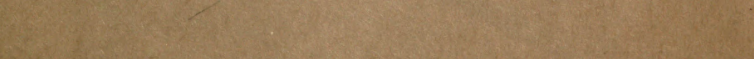

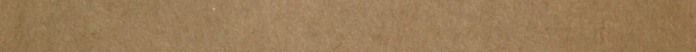
What

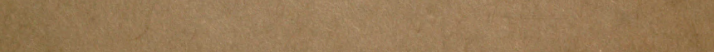

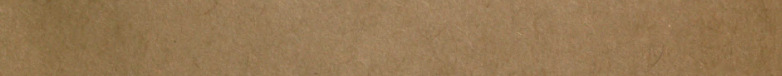

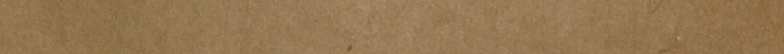

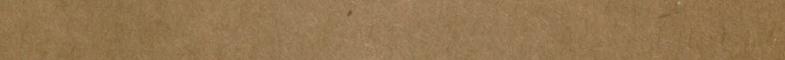







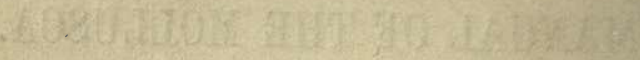

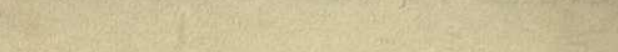

$(4-6)=5$

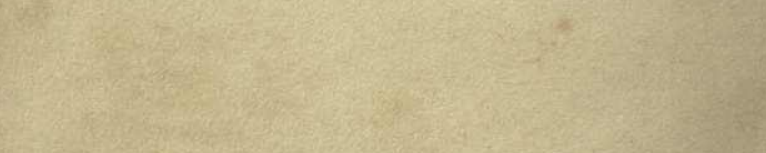




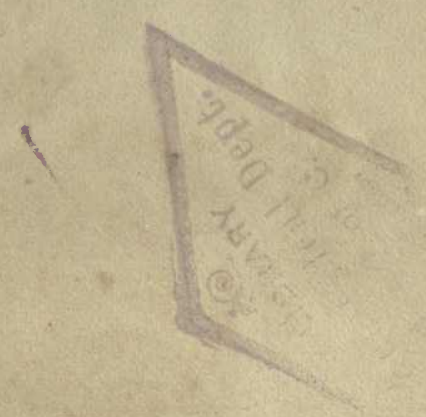




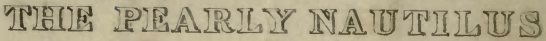

$$
\text { (after-Owen) }
$$

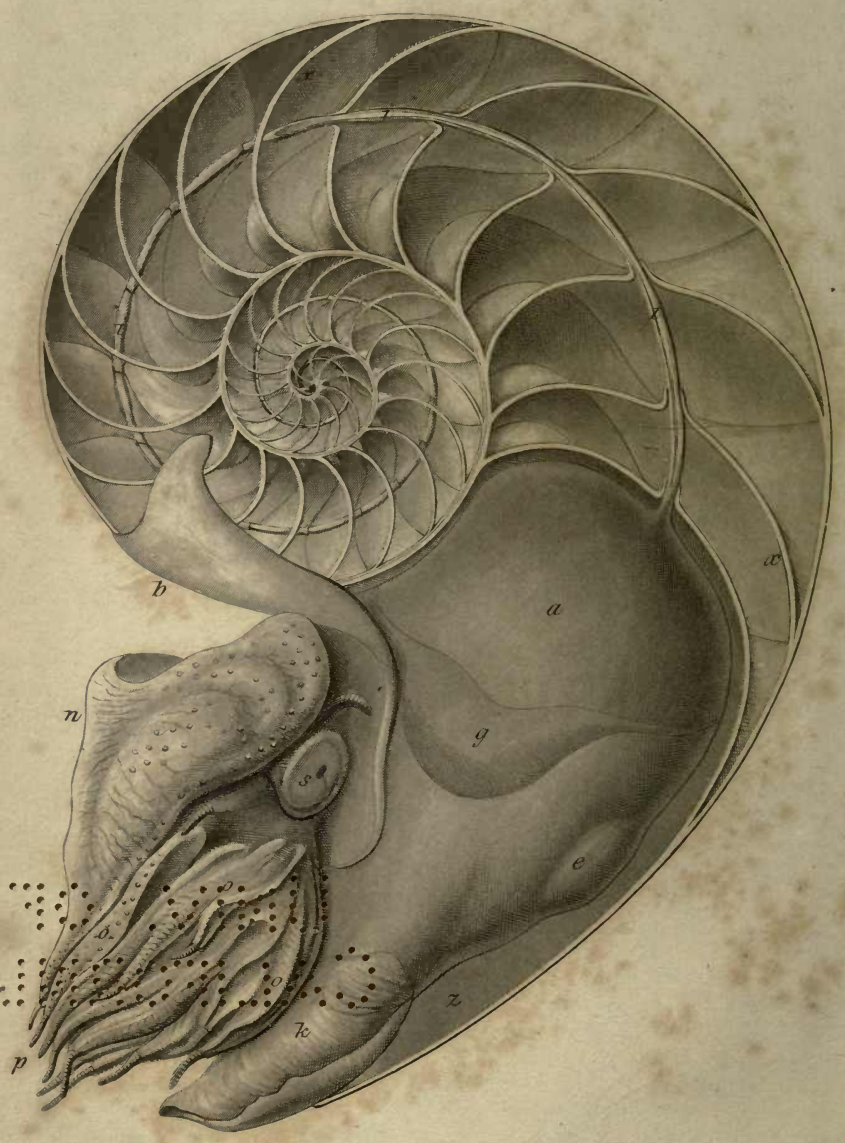

a The mantle

$b$ Its Aorsal tolal

e - Aidamental indand

g shell muscle

i i i siphom

k fimnel

$$
\begin{aligned}
& n \text { Hood } \\
& \text { o co Frterim digitations } \\
& p \text { Tentacles } \\
& \text { s Eve } \\
& \text { x.o Septa } \\
& z \text { Last Chamber }
\end{aligned}
$$




\section{MANUAL OF THE MOLLUSCA; 1 . \\ OR, A}

\section{RUDIMENTARY TREAT,ISE}

OF

\section{RECENT AND FOSSIL SHELLS.}

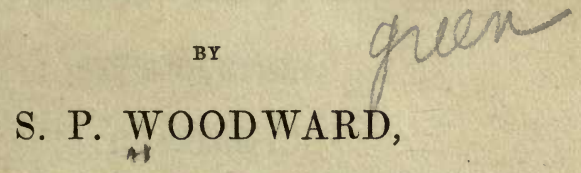

ASSOCIATE OF THE LINNEAN SOCIETY;

ASSISTANT IN THE DEPARTMENT OF MINERALOGY AND GEOLOGY

IN THE BRITISH MUSEUM; AND

MEMBER OF THE COTTESWOLDE NATURALISTS' CLUB.

\section{ILLUSTRATED BY}

A. N. WATERHOUSE AND JOSEPH WILSON LOWRY.

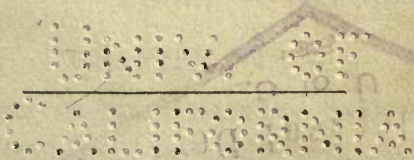

LONDON :

JOHN WEALE, 59, HIGH HOLBORN. 


\section{Q $<403$ W 7 V.I}

Brolocr? LIBRARY

\section{G}

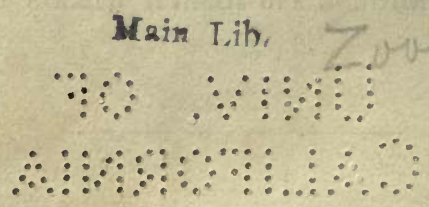

L ONDON

PRINTED BY WILIIAM OSTELL, HART STREET, BLOOMSBURY. 


\section{CONTENTS.}

Table of the Sub-kingdoms and Classez of Animals

\section{INTRODUCTION.}

\section{CHAPTER I.}

On the Position of the Mollusca in the Animal Kingdom. -Characters of the four primary groups;-VertebrataMollusca-Articulata-Radiata. Their equal antiquity ... 3

\section{CHAPTER II.}

Classes of the Mollusca.-1. Cephalopoda.-2. Gasteropoda. -3. Pteropoda. - 4. Brachiopoda. - 5. Conchifera. - 6. Tunicata

\section{CHAPTER III.}

Habits and Economy of the Mollusca.-Sedentary tribes, their mode of attachment; locomotive tribes, their means of progression; situations frequented by shell-fish.-Food : vegetable- infusorial- and animal-feeders.-Use of shell-ish to other animals for food; use of shells for ornamental and other purposes; prices of shells.-Duration of molluscous animals; tenacity of life; fecundity; oviposition

\section{2}


Structure and Physiology of the Mollusca. - Nervous system; organs of sense.-Muscular system.-Digestive system; lingual teeth; secretions.-Circulating system; aquiferous canals. - Respiratory system. - The shell, its composition and structure; nacreous, fibrous, and porcellaneous shells; epidermis; erosion of fresh-water shells. Formation and growth of the shell; adult characters; decollated shells; monstrosities; colours; the operculum; homologies.-Temperature and hybernation. - Reproduction : of lost parts; by gemmation; viviparous; alternate; oviparous.-Development

\section{CHAPTER V.}

Classification.-Affinities; analogies ; species; genera ; families; the quinary system

\section{CHAPTER VI.}

NomencLatore.-Synonyms; anthorities; types ............. 59

ABBREVIATIONS

\section{SYNOPSIS OF THE GENERA.}

Class I. Cephalopoda. Order I. Dibranchiata ........... 62

SECTION A. OCTOPODA.......................................... 64

Fam. I. Argonautida.-Argonauta ....................... 66

Fam. II. Octopodida.-Octopus, Pinnoctopus, Eledone,

Cirroteuthis, Philonexis

Section B. Decapoda

Fam. III. Teuthida.-Loligo, Gonatus, Sepioteuthis, Belotenthis, Geoteuthis, Leptoteuthis, Cranchia, Sepiola, Loligopsis, Cheiroteuthis, Onychoteuthis, Enoploteuthis, Ommastrephes 
Fam. IV. Belemnitida.-Belemnites, Belemnitella, Acanthoteuthis, Belemnites, Belemnoteuthis, Conoteuthis ... 73

Fam. V. Sepiada.-Sepia, Spirulirostra, Beloptera, Belemnosis

Fam. VI. Spirulida.-Spirula

Order II. Tetrabranchiata.

Fam. I. Nautilide.-Nautilus, Lituites, Trochoceras, Clymenia

Fam. II. Orthoceratida.-Orthoceras, Gomphoceras, Oncoceras, Phragmoceras, Cyrtoceras, Gyroceras, Ascoceras

Fam. III. Ammonitida.-Goniatites, Bactrites, Ceratites, Ammonites, Crioceras, Turrilites, Hamites, Ptychoceras, Baculites

Class II. Gasteropoda

Order I. Prosobranchiata

Fam. I. Strombida.-Strombus, Pteroceras, Rostellaria, Seraphs.

Fam.II. Muricida.-Murex, Pisania, Ranella, Triton, Fasciolaria, Turbinella, Cancellaria, Trichotropis, Pyrula, Fusus

Fam. III. Buccinida.-Buccinum, Pseudoliva, Anolax, Halia, Terebra, Eburna, Nassa, Phos, Ringicula?, Purpura, Purpurina, Monoceros, Pedicularia, Ricinula, Planaxis, Mayilus, Cassis, Oniscia, Cithara, Cassidaria, Dolium, Harpa, Columbella, Oliva, Ancillaria

Fam. IV. Conida.-Conus, Pleurotoma

Fam. V. Volutida.-Voluta, Cymba, Mitra, Volvaria, Marginella

Fam.VI. Cyprcida.-Cypræa, Erato, Ovulum 
Section B. Holostomata

Fan. I. Naticida.-Natica, Sigaretus, Lamellaria, Narica, Velutina.

Fam. II. Pyramidellida.-Pyramidella, Odostomia, Chemnitzia, Stylina, Loxonema, Macrocheilus..................... 125

Fam. III. Cerithiade.-Cerithium, Potamides, Nerinæa, Fastigiella, Aporrhais, Struthiolaria

Fam. IV. Melaniada.-Melania, Paludomus, Melanopsis... 130 Fam.V. Turritellide.-Turritella, Aclis, Cæcum, Verme-

tus, Siliquaria, Scalaria..................................... 132

Fan.VI. Litorinida.-Litorina, Solarium, Phorus, Lacuna,

Litiopa, Rissoa, Skenea, Truncatella, ? Lithoglyphus ... 134 Fam.VII. Paludinida.-Paludina, Ampullaria, Amphibola,

Valvata

Fam.VIII. Neritida.-Nerita, Pileolus, Neritina, Navicella 140 Fam. IX. Turbinida.-Turbo, Phasianella, Imperator, Trochus, Rotella, Monodonta, Delphinula, Adeorbis, Euomphalus, Stomatella, Broderipia............................. 142

Fam. X. Haliotis.-Haliotis, Stomatia, Scissurella, Pleurotomaria, Murchisonia, Trochotoma, Cirrus, Ianthina ..... 146 Fam. XI. Fissurellida.-Fissurella, Puncturella, Rimula, Emarginula, Parmophorus.

Fam. XII. Calyptraide.-Calyptræa, Crepidula, Pileopsis,

Hipponyx

Fam. XIII. Patellida.-Patella, Acmæa, Gadinia, Siphonaria 153

Fam. XIV. Dentaliada.-Dentalium ........................ 156

Fam. $X V$. Chitonida.-Chiton ............................. 156 


\section{NOTICE.}

THE second part of this Manual is now in preparation, and will be published early in the summer. It will contain an account of the remaining orders of shell-fish: a chapter on the Geographical Distribution of the Mollusca, with a Map of the Marine and Terrestrial Provinces; a chapter on the distribution of Fossil Shells; another on the methods of collecting and preserving Land, Fresh-water, and Sea-shells; the Preface; and an Index of the genera and technical terms.

The writer desires to acknowledge his obligations to $\mathrm{Mr}$. Hugh Cumming, Professor Edward Forbes, and other gentlemen who have assisted him by advice, and the loan of specimens; lso to Mr. Van Voorst, for permission to copy some interesting igures from the "British Mollusca ;" and his thanks are most specially due to Mr. John Edward Gray, Keeper of the Zoolofical Department of the British Museum, for access to his library and cabinet, and the use of some of the best engravings which llustrate these pages. 


\section{Kingdom ANIMALIA.}

SUb-KINGdom I. VERTEBRATA.

- Class I. Mammalia.

II. Aves.

III. Reptilia.

IV. Pisces.

StB-KINGDOM II. MOLLUSCA.

Class I. Cephalopoda.

iI. Gasteropoda.

III. Pteropoda.

IV. BRACHIOPODA.

V. Conchifera.

VI. Tunicata.
SUB-KINGDOM III. ARTICULATA.
Class I. Insecta.

II. Arachnida.

III. Crustacea.

IV. CtrRipeda.

V. ANEllata.

VI. Entozoa.

\section{SUb-KINGdoM IV. RADIATA.}

Class I. Acalepha.

II. Echinodermata.

III. ZoOPHYTA.

IV. Foraminifera.

V. INFUSORIA.

VI. AmorphozoA. 


\title{
MANUAL OF THE MOLLUSCA.
}

\section{INTRODUCTION.}

\author{
Chapter I.
}

\section{ON THE POSITION OF THE MOLLUSCA IN THE ANIMAL KINGDOM.}

ALI known animals are constructed upon four different types, and constitute as many natural divisions or sub-kingdoms.

1. The first of these primary groups is characterized by an internal skeleton, of which the essential, or ever-present part, is a backbone, composed of numerous joints, or vertebra. These are the animals most familiar to us; beasts, birds, reptiles, and fishes, are four classes which agree in this one respect, and are hence collectively termed vertebrate animals, or the vertebrata.

2. Another type is exemplified in the common garden-snail, the nautilus, and the oyster; animals whose soft bodies are protected by an external shell, which is harder than bone, and equally unlike the skeleton of fishes, and the hard covering of the crab and lobster. These creatures form the subject of the present history, and are called mollusca.*

- Mollusca soft (animals), from mollis. The Greeks termed them Malakia, whence the modern word Malacology, or the study of shell-fish. 
3. The various tribes of insects, spiders, crabs, and worms; have no internal skeleton; but to compensate for it, their outer integument is sufficiently hard to serve at once the purposes of bones, and of a covering and defence. This external armature, like the bodies and limbs which it covers, is divided into segments or joints, which well distinguishes the members of this group from the others. The propriety of arranging worms with insects will be seen, if it be remembered, that even the butterfly and bee commence existence in a very worm-like form. This division of jointed animals bears the name of the articulata.

4. The fourth part of the animal kingdom consists of the coral-animals, star-fishes, sea-jellies, and those countless microscopic beings which swarm in all waters. Whilst other animals are bi-lateral, or have a right and left side, and organs arranged in pairs, - these have their organs placed in a circle around the mouth or axis of the body, and have hence obtained the appellation of radiata.

These groups illustrate successively the grand problems of animal economy. The lower divisions exhibit the perfectionizing of the functions of nutrition and reproduction; the higher groups present the most varied and complete development of the senses, locomotive powers, and instincts. We may also trace in them an ideal progression from the simplest to the most complicated structure and conditions. Commencing with the Infusorial monad, we may ascend in imagination by a succession of closely allied forms, to the sea-urchin and holothuria*; and thence by the lowest organized worms, upwards to the flying insect. Or, starting at the same point, we may pass from the polypes to the tunicaries; and from the higher kinds of shellfish to the true fishes, and so on to those classes whose physical organization is most nearly identical with our own.

The mollusca are thus related to two of the other primary groups;-by the affinity of their simpler forms to the zooplytes, 
and of their highest class to the fishes; - to the cirripedes and other articulate animals, they present only superficial and illusive resemblance.

And further, we shall find that although it is customary to speak of shell-fish as "less perfect" animals, yet they really attain the perfection of their own type of structure; indeed it would seem to have been impossible to make any further advance, physical, or psychical, except by adopting a widely different plan from that on which the molluscous animals have been constructed.

The evidence afforded by geological researches at present tends to shew that the four leading types of animal structure have existed simultaneously from the very beginning of life upon the globe;* and though perpetually varying in the form under which they were manifested, they have never since entirely ceased to exist.

By adding to the living population of the world, those forms which peopled it in times long past, we may arrive at some dim conception of the great scheme of the animal kingdom. And if at present we see not the limits of the temple of nature, nor fully comprehend its design, - at least we can feel sure that there is a boundary to this present order of things; and that there has been a plan, such as we, from our mental constitution, are able to appreciate, and to study with ever-increasing admiration.

* Mr E. Logan, Geological Surveyor of the Canadas, has discovered foot prints of a tortoise, near Montreal, in the "Lingula Shale," or oldest fossibiferous rock at present known. 
Chapter II.

\section{CLASSES OF THE MOLLUSCA.}

THE mollusca are animals with soft bodies, enveloped in a muscular skin, and usually protected by a univalve or bivalve shell. That part of their integument which contains the viscera and secretes the shell, is termed the mantle; in the univalves it takes the form of a sac, with an opening in front, from which the head and locomotive organs project: in the bivalves it is divided into two lobes.

The univalve mollusca are encephalous, or furnished with $\mathrm{B}$ distinct head; they have eyes and tentacula, and the mouth is armed with jaws. Cuvier has divided them into three classes, founded on the modifications of their feet, or principal locomotive organs.

1. The cuttle-fishes constitute the first-class, and are termed cephalopoda,* because their feet, or more properly arms, are attached to the head, forming a circle round the mouth.

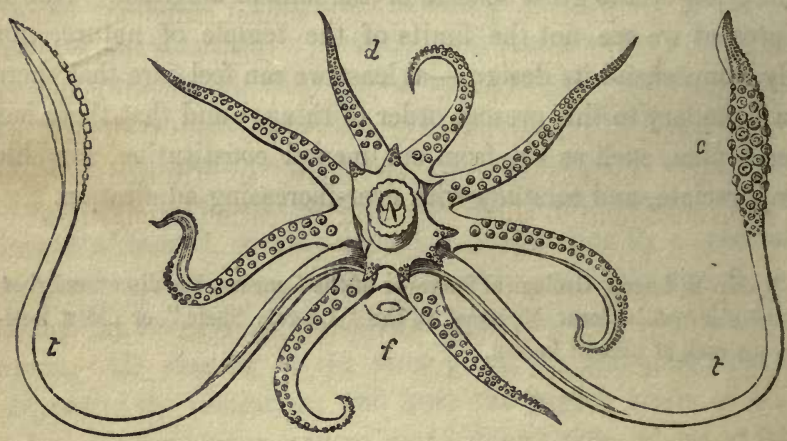

Fig. 1.t Oral aspect of a Cephalopod.

* From Cephale, the head and poda feet. See the frontispiece and pl. I.

† Fig. 1. Loligo vulgaris, Lam. $\frac{1}{4}$. From á specimen taken off Tenby, by J. S. Bowerbank, Esq. The mandibles are seen in the centre, surrounded by the circular lip, the buccul membrane (with two rows of small cups on its lobes), the eight sessile arms, and the long pedunculated tentacles ( $t$ ), with their enlarged extremities or clubs (c). The dorsal arms are lettered (d), the funnel (f). 
2. In the gasteropoda,* or snails, the under side of the body forms a single muscular foot, on which the animals creep or glide.

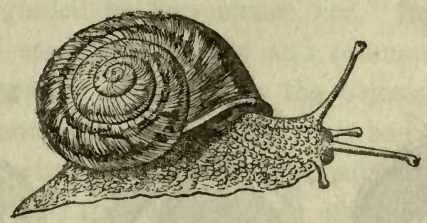

Fig. 2. 4 Gasteropod. $\dagger$

3. The pterpoda $\ddagger$ only inhabit the sea, and swim with a pair of fins, extending outwards from the sides of the head.

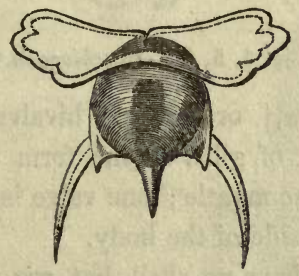

Fig. 3. A Pteropod. $\$$

The other mollusca are acephalous, or destitute of any distinct head; they are all aquatic, and most of them are attached, or have no means of moving from place to place. They are divided into three classes, characterized by modifications in their breathing-organ and shell.

4. The brachiapoda 9 are bivalves, having one shell placed on the back of the animal, and the other in front; they have no

* Gaster, the under side of the body.

+ Fig. 2. Helix desertorum. Forskal. From a living specimen in the British Museum, March, 1850.

$\ddagger$ Pteron, a wing.

\$. Fig. 3. Hyaloea tridentata, Lam., from Quoy and Gaimard.

If Brachion, an arm; these organs were supposed to take the place of the feet in the preceding classes. 
special breathing organ, but the mantle performs that office; they take their name from two long ciliated arms, developed from the sides of the mouth, with which they create currents that bring them food.
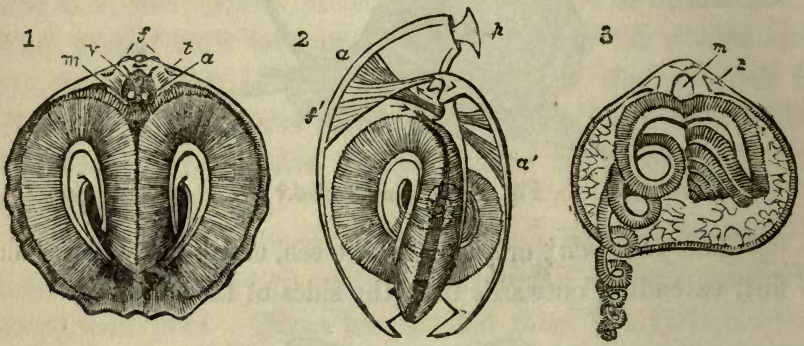

Fig. 4, 5, 6. Brachiopoda.*

5. The conchifera, $\uparrow$ or ordinary bivalves, (like the oyster), breathe by two pairs of gills, in the form of flat membraneous plates, attached to the mantle; one valve is applied to the right, the other to the left side of the body.

6. The tunicata have no shell, but are protected by an elastic, gelatinous tunic, with two orifices; the breathing-organ takes the form of an inner tunic, or of a riband stretched across the internal cavity.

Five of these modifications of the molluscan type of organization, were known to Linnæus, who referred the animals of all his genera of shell-fish to one or other of them ; $\ddagger$ but unfortunately he did not himself adopt the truth which he was the first

* Fig. 4. (3). Rhynchonella psittacea, Chem, sp., dorsal valve, with the animal (after Owen). 5, 6, Terebratula australis, Quoy. From specimens collected by Mr. Jukes. (2). Ideal side view of both valves, (f, the retractor muscles, by which the valves are opened). (1). Dorsal valve. These woodcuts have been kindly lent by Mr. J. E. Gray.

+ Conchifera, Shell-bearers.

‡ The Linnæan types were-Sepia, Limax, Clio, Anomia, Ascidia. Terebratula was included with Anomia, its organization being unknown. 
to see ; and here, as in his botany, employed an artificial, in preference to a natural method.

The systematic arrangement of natural objects ought not, however, to be guided by convenience, nor " framed merely for the purposes of easy remembrance and communication." The true method must be suggested by the objects themselves, by their qualities and relations;-it may not be easy to learn,-it may require perpetual modification and adjustment,-but inasmuch as it represents the existing state of knowledge it will aid in the UNDERSTANDING of the subject, whereas a "dead and arbitrary arrangement" is a perpetual bar to advancement, "containing in itself no principle of progression." (Coleridge.)

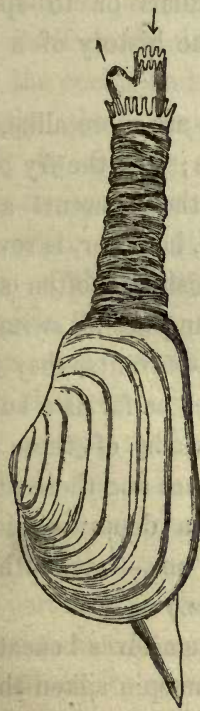

Fig. 7. A Bivalve.*

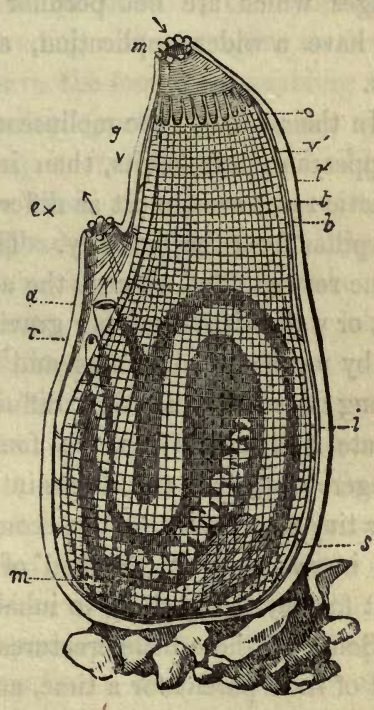

Fig. 8. 4 Tunicary. $\dagger$

Mya truncata, L. $\frac{1}{2}$. From Forbes and Hanley.

† Ascidia mentula, Müll. Ideal representation; from a specimen dredged by Mr. Bowerbank, off T'enby. 
Chapter III.

\section{HABITS AND ECONOMY OF THE MOLLUSCA.}

EVERY living creature has a history of its own; each has characteristics by which it may be known from its relatives; each has its own territory, its appropriate food, and its duties to perform in the economy of nature. Our present purpose, however, is to point out those circumstances and trace the progress of those changes which are not peculiar to individuals or to species, but have a wider application, and form the history of a great class.

In their infancy the molluscous animals are more alike, both in appearance and habits, than in after life; and the fry of the acquatic races are almost as different from their parents as the caterpillar from the butterfly. The analogy, however, is reversed in one respect; for whereas the adult shell-fish are often sedentary, or walk with becoming gravity, the young are all swimmers, and by means of their fins and the ocean-currents, they travel to long distances, and thus diffuse their race as far as a suitable climate and conditions are found. Myriads of these little voyagers drift from the shores into the open sea and there perish; their tiny and fragile shells become part of a deposit that is for ever increasing over the bed of the deep sea,-at depths too great for any living thing to inhabit. (Forbes.)

Some of these little creatures shelter themselves beneath the shell of their parent for a time, and many can spin silken threads with which they moor themselves, and avoid being drifted away. They all have a protecting shell, and even the young bivalves have eyes at this period of their lives, to aid them in choosing an appropriate locality.

After a few days, or even less, of this sportive existence, the 
sedentary tribes settle in the place they intend to occupy during the remainder of their lives. The tunicary cements itself to rock or sea-weed; the shipworm adheres to timber, and the pholas and lithodomus to limestone rocks, in which they soon excavate a chamber which renders their first means of anchorage unnecessary. The mya and razor-fish burrow in sand or mud; the mussel and pinna spin a byssus; the oyster and spondylus attach themselves by spines or leafy expansions of their shell; the brachiopoda are all fixed by similar means, and even some of the gasteropods become voluntary prisoners, as the hipponyx and vermetus.

Other tribes retain the power of travelling at will, and shift their quarters periodically, or in search of food; the river-mussel drags itself slowly along by protruding and contracting its flexible foot; the cockle and trigonia have the foot bent, enabling them to make short leaps; the scallop (pector opercularis) swims rapidly by opening and shutting its tinted valves. Nearly all the gasteropods creep like the snail, though some are much more active than others; the pond-snails can glide along the surface of the water, shell-downwards; the nucleobranches and pteropods swim in the open sea. The cuttle-fishes have a strange mode of walking, head-downwards, on their outspread arms; they can also swim with their fins, or with their webbed arms, or by expelling the water forcibly from their branchial chamber; the calamary can even strike the surface of the sea with its tail, and dart into the air like the flying-fish. (Owen.)

By these means the mollusca have spread themselves over every part of the habitable globe; every region has its tribe; every situation its appropriate species; the land-snails frequent moist places, or woods, or sunny banks and rocks, climb trees, or burrow in the ground. The air-breathing limneids live in fresh-water, only coming occasionally to the surface; and the auriculas live on the sea-shore, or in salt-marshes. In the sea, each zone of depth has its molluscous fauna. The limpet and periwinkle live between tide-marks, where they are left dry twice 
a-day; the trochi and purpurce are found at low water, amongst the sea-weed; the mussel affects muddy shores, the cockle rejoices in extensive sandy flats. Most of the finely-coloured shells of the tropics are found in shallow water, or amongst the breakers. Oyster-banks are usually in four or five fathom water; scallopbanks at twenty fathoms. Deepest of all, the terebratula are found, commonly at fifty fathoms, and sometimes at one hundred fathoms, even in Polar seas. The fairy-like pteropoda, the oceanic-snail, and multitudes of other floating molluscs, pass their lives on the open sea, for ever out of sight of land ; whilst the litiopa and scyllea follow the gulf-weed in its voyages, and feed upon the green delusive banks.

The food of the mollusca is either vegetable, infusorial, or animal. All the land-snails are vegetable-feeders, and their depredations are but too well known to the gardener and farmer; many a crop of winter corn and spring tares has been wasted by the ravages of the "small grey slug." They have their likings, too, for particular plants, most of the pea-tribe and cabbagetribe are favourites, but they hold white mustard in abhorence, and fast or shift their quarters while that crop is on the ground.* Some, like the "cellar-snail," feed on cryptogamic vegetation, or on decaying leaves; and the slugs are attracted by fungi, or any odorous substances. The round-mouthed sea-snails are nearly all vegetarians, and consequently limited to the shore and the shallow waters in which sea-weeds grow. Beyond fifteen fathoms, almost the only vegetable production is the nullipore; but here corals and horny zoophytes take the place of algoe and afford a more nutritious diet.

The whole of the bivalves, and other head-less shell-fish, live on infusoria, or on microscropic vegetables, brought to them by the current which their ciliary apparatus perpetually excites; such, too, must be the sustenance of the magilus, sunk in its

* Dilute lime-water and very weak alkaline solutions are more fatal to snails than even salt. 
coral bed, and of the calyptroea, fettered to its birth-place by its calcarious foot.

The carnivorous tribes prey chiefly on other shell-fish, or on zoophytes; since, with the exception of the cuttle-fishes, their organization scarcely adapts them for pursuing and destroying other classes of animals. One remarkable exception is formed by the stylina, which lives parasitically on the star-fish and seaurchin; and another by the testacelle, which preys on the common earth-worm, following it in its burrow, and wearing a buckler, which protects it in the rear.

Most of the siphonated univalves are animal-feeders; the carrion-eating stromb and whelk consume the fishes and other creatures whose remains are always plentiful on rough and rocky coasts. Many wage war on their own relatives, and take them by assault; the bivalve may close, and the operculated nerite retire into his home, but the enemy, with rasp-like tongue, armed with silicious teeth, files a hole through the shell,- vain shield where instinct guides the attack! Of the myriads of small shells which the sea heaps up in every sheltered "ness," a large proportion will be found thus bored by the whelks and purples; and in fossil shell-beds, such as that in the Touraine, nearly half the bivalves and sea-snails are perforated,-the relics of antediluvian banquets.

This is on the shore, or on the bed of the sea; far away from land the carinaria and frola pursue the floating acalephe; and the argonaut, with his relative the spirula, both carnivorous, are found in the "high seas," in almost every quarter of the globe. The most active and rapacious of all are the calamaries and cuttles, who vindicate their high position in the naturalists' "system," by preying even on fishes.

As the shell-fish are great eaters, so in their turn they afford food to many other creatures ; fulfilling the universal law of eating, and being eaten. Civilized man still swallows the oyster, although snails are no longer reckoned "a dainty dish;" mussels, cockles, and periwinkles are in great esteem with children and 
the other unsophisticated classes of society; and so are scallops and the haliotis, where they can be obtained. Two kinds of whelk are brought to the London market in great quantities; and the arms of the cuttle-fish are eaten by the Neapolitans, and also by the East Indians and Malays. In seasons of scarcity, vast quantities of shell-fish are consumed by the poor inhabitants of the Scotch and Irish coasts.* Still more are regularly collected for bait; the calamary is much used in the cod-fishery, off Newfoundland, and the limpet and whelk on our own coasts.

Many wild animals feed on shell-fish; the rat and the racoon seek for them on the sea-shore when pressed by hunger; the South-American otter, and the crab-eating opossum constantly resort to salt-marshes, and the sea, and prey on the mollusea; the great whale lives habitually on the small floating pteropods; sea-fowl search for the litoral species at every ebbing tide; whilst, in their own element, the marine kinds are perpetually devoured by fishes. The haddock is a "great conchologist ;" and some good northern sea-shells have been rescued, unbroken, from the stomach of the cod; whilst even the strong valves of the cyprina are not proof against the teeth of the cat-fish (anarhicas).

They even fall a prey to animals much their inferiors in sagacity ; the star-fish swallows the small bivalve entire, and dissolves the animal out of its shell; and the bubble-shell (phyline), itself predacious, is eaten both by star-fish and sea-anemone (actinia).

The land-snails afford food to many birds, especially to the thrush tribe; and to some insects, for the luminous larva of the glow-worm lives on them, and some of the large predacious beetles (e.g. carabus violaceus and goerius olens), occasionally kill slugs.

The greatest enemies of the mollusca, however, are those of their own nation; scarcely one-half the shelly tribes graze peace- 
fully on sea-weed, or subsist on the nutrient particles which the sea itself brings to their mouths ; the rest browse on living zoophytes, or prey upon the vegetable-feeders.

Yet in no class is the instinct of "self-preservation" stronger, nor the means of defence more adequate; their shells seem expressly given to compensate for the slowness of their movement, and the dimness of their senses. The cuttle-fish escapes from attack by swimming backwards and beclouding the water with an inky discharge; and the sea-hare (aplysia) pours out, when irritated, a copious purple fluid, formerly beld to be poisonous. Others rely on passive resistance, or on concealment for their safety. It has been frequently remarked that molluscs resemble the hue and appearance of the situation they frequent; thus, the limpet is commonly overgrown with balani and sea-weed, and the ascidian with zoophytes, which form an effectual disguise; the lima and modiola spin together a screen of grotto-work. One ascidian (a. cochligera) coats itself with shell-sand, and the carrier-trochus cements shells and corals to the margin of its habitation, or so loads it with pebbles, that it looks but like a little heap of stones.

It must be confessed that the instincts of the shell-fish are of a low order, being almost limited to self-preservation, the escape from danger, and the choice of food. Their history offers none of those marvels which the entomologist loves to relate. An instance of something like social feeling has been observed in a Roman snail (helix pomatia) who, after escaping from a garden, returned to it in quest of his fellow-prisoner;-but the accomplished naturalist who witnessed the circumstance hesitated to record a thing so unexampled. The limpet, too, if we may trust the observations of Mr. Robert, of Lyme Regis, is fond of home, or at least possesses a knowledge of topography, and returns to the same roost after an excursion with each tide. Professor Forbes has immortalized the sagacity of the razor-fish, who submits to be salted in his hole, rather than expose himself to be caught, after finding that the enemy is lying in wait for him. 
On the other hand, Mr. Bowerbank has a curious example of " instinct at fault," in the fossil spine of a sea-urchin, which appears to have been drilled by a carnivorous gasteropod!

We have spoken of shell-fish as articles of food, but they have other uses, even to man; they are the toys of children, who hear in them the roaring of the sea; they are the pride of "collectors" -whose wealth is in a cone or "wentle-trap;"* and they are the ornaments of barbarous tribes. The Firiendly-islander wears the orange-cowry as a mark of chieftanship (Stutclibury), and the New Zealander polishes the elenchus into an ornament more brilliant than the "pearl ear-drop" of classical or modern times. (Clarke.) One of the most beautiful substances in nature is the shell-opal, formed of the remains of the ammonite. The forms and colours of shells (as of all other natural objects), answer some particular purpose, or obey some general law ; but besides this, there is much that seems specially intended for our study, and calculated to call forth enlightened admiration. Thus the tints of many shells are concealed during life by a dull external coat, and the pearly halls of the nautilus are seen by no other eyes than ours. Or descending to mere "utility," how many tracts of coast are destitute of limestone, but abound in shell-banks which may be burned into lime; or in shell-sand, for the use of farmers. $\dagger$

* The extravagant prices that have been given for rare shells, are less to be regretted, because they have induced voyagers to collect. Mere shell-collecting, however, is no more scientific than pigeon-fancying, or the study of old china. For educational purposes the best shells are the types of genera, or species which illustrate particular points of structure; and, fortunately for stndents, the prices are much diminished of late years. A Carinaria once "worth 100 guineas" (Sowerby) is now worth 1s. only; a Wentle-trap which fetched 40 guineas in $1701^{\circ}$ (Rumphius) was worth only 20 guineas in 1753 , and may now be had for $5 \mathrm{~s} .1$ The Conus gloria-maris has fetched $£ 50$ more than once, and Cyprcea umbilicata has been sold for $\mathfrak{E} 30$ this year, 1850 .

+ Shell-sand is only beneficial on peaty soils, or heavy clay land. It sometimes hardens into limestone, as on the coast of Devon; and at Guadaloupe, where it contains litoral shells and human skeletons of recent date. 
Not much is known respecting the individual duration of the shell-fish, though their length of life must be very variable. Many of the aquatic species are annuals, fulfilling the cycle of their existence in a single year; whole races are entombed in the wintry tide of mud that grows from year to year in the beds of rivers, and lakes, and seas ; thus, in the Wealden clay we find layer above layer of small river-snails, alternating with thin strata of sediment, the index of immeasureably distant years. Dredgers find that-whilst the adults of some shell-fish can be taken at all seasons, others can be obtained late in the autumn or winter only; those caught in spring and summer being young, or half-grown; and it is a common remark that dead shells (of some species) can be obtained of a larger size than any that we find alive, because they attain their full-growth at a season when our researches are suspended. Some species require part of two years for their full development; the young of the doris and eolis are born in the summer time, in the warm shallows near the shore; on the approach of winter they retire to deeper water, and in the following spring return to the tidal rocks, attain their full-growth early in the summer, and after spawning-time disappear.

The land-snails are mostly biennial; hatched in the summer and autumn, they are half-grown by the winter-time, and acquire their full-growth in the following spring or summer. In confinement, a garden-snail will live for six or eight years; but in their natural state it is probable that a great many die in their second winter, for clusters of empty shells may be found, adhering to one another, under ivied walls, and in other sheltered situations; the animals having perished in their hybernation. Some of the spiral sea-shells live a great many years, and tell their age in a very plain and interesting manner, by the number of fringes (varices) on their whirls; the contour of the ranella and murex depends on the regular recurrence of these ornaments, which occur after the same intervals in well-fed individuals, as in their less fortunate kindred. The Ammonites appear, by their varices, 
or periodic mouths (pl. III., fig. 3), to have lived and continued growing for many years.

Many of the bivalves, like the mussel and cockle, attain their full-growth in a year. The oyster continues enlarging his shell by annual "shoots," for four or five years, and then ceases to grow outwards; but very aged specimens may be found, especially in a fossil state, with shells an inch or two in thickness. The giant-clam (tridacna), which attains so large a size that poets and sculptors have made it the cradle of the sea-goddess,must enjoy an unusual longevity; living in the sheltered lagoons of coral-islands, and not discursive in its habits, the corals grow up around, until it is often nearly buried by them; but although there seems to be no certain limit to its life (though it may live a century for all that we know), yet the time will probably come when it will be overgrown by its neighbours, or choked with sediment.

The fresh-water molluscs of cold climates bury themselves during winter, in the mud of their ponds and rivers; and the land-snails hide themselves in the ground, or beneath moss and dead leaves. In warm climates they become torpid during the hottest and driest part of the year.

Those genera and species which are most subject to this "summer sleep," are remarkable for their tenacity of life; and numerous instances have been recorded of their importation from distant countries, in a living state. In June, 1850, a living pond-mussel was sent to Mr. Gray, from Australia, which had been more than a year out of water.* The pond-snails (ampullarice) have been found alive in logs of mahogany from Honduras (Mr. Pickering); and M. Caillaud carried some from Egypt to Paris, packed in saw-dust. Indeed, it is not easy to ascertain the limit of their endurance; for Mr. Laidlay having placed a number in a drawer for this purpose, found them alive after five

* "It was alive 498 days after it was taken from the pond; and in the interim had been only twice for a few hours in water, to see if it was alive." Rev. W. O. Newnham. 
years, although in the warm climate of Calcutta. The cyclostomas, which are also operculated, are well known to survive imprisonments of many months; but in the ordinary land-snails such cases are more remarkable. Some of the large tropical bulimi, brought by Lieutenant Graves from Valparaiso, revived after being packed, some for thirteen, others for twenty months. In 1849, Mr. Pickering received from Mr. Wollaston a basket-full of Madeira snails (of twenty or thirty different species), threefourths of which proved to be alive, after several months' confinement, including a sea-voyage. Mr. Wollaston has himself told us that specimens of two Madeira snails (helix papilio and tectiformis) survived a fast and imprisonment in pill-boxes, of two years and a half, and that a large number of the small helix turricula, brought to England at the same time, were all living after being inclosed in a dry bag for a year and a half.

But the most interesting example of resuscitation occurred to a specimen of the Desert snail, from Egypt, chronicled by Dr. Baird.* This individual was fixed to a tablet in the British Museum, on the 25th of March, 1846; and on March 7th, 1850, it was observed that he must have come out of his shell in the interval (as the paper had been discoloured, apparently in his attempt to get away); but finding escape impossible, had again retired, closing his aperture with the usual glistening film; this led to his immersion in tepid water, and marvellous recovery. He is now (March 13th, 1850) alive and flourishing, and has sat for his portrait. (Fig. 2.)

The permanency of the shell-bearing races is effectually provided for by their extreme fecundity; and though exposed to a hundred dangers in their early life, enough survive to re-people the land and sea abundantly. The spawn of a single doris may contain 600,000 eggs (Darwin); a river-mussel has been estimated to produce 300,000 young in one season, and the oyster cannot be much less prolific. The land-snails have fewer enemies, and, fortunately, lay fewer eggs.

* An. Nat. Hist. 1850. 
Lastly, the mollusca exhibit the same instinctive care with insects and the higher animals, in placing their eggos in situations where they will be safe from injury, or open to the influences of air and heat, or surrounded by the food which the young will require. The tropical bulimi cement leaves together, to protect and conceal their large, bird-like, eggs; the slugs bury theirs in the ground; the oceawic-snail attaches them to a floating raft;

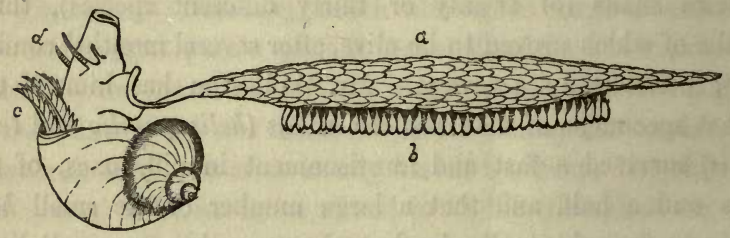

Fig. 9. Ianthina with its raft.

and the argonaut carries them in her frail boat. The horny capsules of the whelk are clustered in groups, with spaces pervading the interior, for the free passage of sea-water ; and the nidamental ribbon of the doris and eolis is attached to a rock, or some solid surface from which it will not be detached by the waves. The river-mussel and cyclas carry their parental care still further, and nurse their young in their own mantle, or in a special marsupium, designed, like that of the opossum, to protect them until they are strong enough to shift for themselves.

If any one imbued with the spirit of Paley or Chate ibriand, should study these phenomena, he might discover more than the "barren facts" which alone appear, without significance, to the unspiritual eye; he would see at every step fresh proofs of the wisdom and goodness of God, who thus manifests his greatness by displaying the same care for the maintenance of his feeblest creatures, as for the well-being of man, and the stability of the world. 


\section{Chapter IV.}

\section{STRUCTURE AND PHYSIOLOGY OF THE MOLIASCA.}

Molluscous animals possess a distinct nervous system, instruments appropriated to the five senses, and muscles by which they execute a variety of movements. They have organs, by which food is procured and digested, - a heart, with arteries and veins, through which their colourless fiuids circulate,-a breathing-organ, - and in most instances, a protecting shell. They produce eggs; and the young generally pass through one preparatory, or larval, stage.

The nervous system, upon which sensation and the exercise of muscular motion depend, consists of a brain or principal centre, and of various nerves possessing distinct properties: the optic nerves are only sensible of light and colours ; the auditory nerves convey impressions of sound; the olfactory, of odours; the gustatory, of flavours; whilst the nerves of touch or feeling are widely diffused, and indicate in a more general way the presence of external objects. The nerves by which motion is produced, are distinct from these, but so accompany them as to appear like parts of the same cords. Both kinds of nerves cease to act when their connection with the centre is interrupted or destroyed. There is reason to believe, that most of the movements of the lower animals result from the reflection of external stimulants (like the process of breathing in man), without the intervention of the will.*

In the mollusca, the principal part of the nervous system is a ring surrounding the throat (ocsophagus), and giving off nerves to different parts of the body. The points from which the nerves radiate, are enlargements, termed centres (ganglia), those on the

* See Müller's Elements of Philosophy, edited by Dr. Baly. 
sides and upper part of the ring represent the brain, and supply nerves to the eyes, tentacles, and mouth; other centres, connected with the lower side of the csophageal ring, send nerves to the foot, viscera, and respiratory organ. In the bivalves, the branchial centre is the most conspicuous, and is situated on the posterior adductor muscle. In the tunicaries, the corresponding nervous centre may be seen between the two orifices in the muscular tunic. This scattered condition of the nervous centres is eminently characteristic of the entire sub-kingdom.

Organs of special sense.-Sight. The eyes are two in number, placed on the front or sides of the head; sometimes they are sessile, in others stalked, or placed on long pedicels (ommatophora). The eyes of the cuttle-fishes resemble those of fishes in their large size and complicated structure. Each consists of a strong fibrous globe (slerotic), transparent in front (cornea), with the opposite interual surface (retina) covered by a dark pigment which receives the rays of light. This chamber is occupied by an aqueous humour, a crystalline lens, and a vitreous humour, as in the human eye. In the strombidoe, the eye is not less highly organised, but in most of the gasteropoda it has a more simple structure, and perhaps only possesses sensibility of light without the power of distinct vision. The larval bivalves have also a pair of eyes in the normal position (fig. 30) near the mouth; but their development is not continued, and the adults are either eyeless, or possess merely rudimentary organs of vision, in the form of black dots (ocelli) along the margin of the mantle.* These supposed eyes have been detected in a great many bivalves, but they are most conspicuous in the scallop, which has received the name of argus from Poli, on this account (fig. 10).

In the tunicaries similar ocelli are placed between the tentacles which surround the orifices.

* "Each possesses a cornea, lens, choroid and nerve; they are, without doubt, organs of vision."-Garner. 


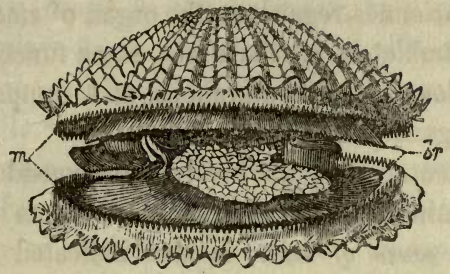

Fig. 10. Pecten varius.*

Sense of Hearing. In the highest cephalopods, this organ consists of two cavities in the rudimentary cranium which protects the brain ; a small calcarious body or otolithe is suspended in each, as in the vestibular cavities of fishes. $\dagger$ Similar auditory capsules occur near the base of the tentacles in the gasteropoda, and they have been detected, by the ribration of the otolithes, in many bivalves and brachiopods. With the exception of tritonia and eolis, none of mollusca have been observed to emit sounds. (Grant).

Sense of Smell. This faculty is evidently possessed by the cuttle-fishes and gasteropods; snails discriminate their food by it, slugs are attracted by offensive odours, and many of the marine zoophaga may be taken with animal baits. In the pearly nautilus, there is a hollow plicated process beneath each eye,

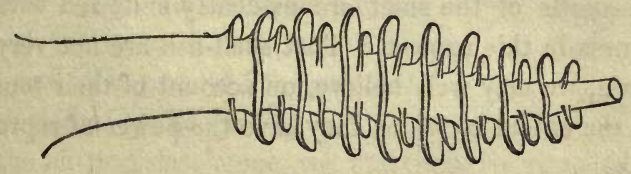

Fig. 11. Tentacle of a Nudibranch. $\ddagger$

* Pecten varius, L., from a specimen dredged by Mr. Bowerbank, off Tenby; $m$, the pallial curtains; $b r$, the branchice.

+ In the Octopods, there is a foramen near the eye, and in some of the Calamaries a plicated organ, which M. D'Orbigny regards as an external ear.

\$ Fig. 11. Tentacle of Eolis coronata, Forbes, from Alder and Haneock. 
which M. Valenciennes regards as the organ of smell*. Messrs. Hancock and Embleton attribute the same function to the la. mellated tentacles of the nudibranchs, and compare them with the olfactory organs of fishes.

The labial tentacles of the bivalves are considered to be organs for discriminating food, but in what way is unknown (fig. 18. l. t. $)^{\circ}$ The sense of taste, is also indicated rather by the habits of the animals, and their choice of food, than by the structure of a special organ. The acephala appear to exercise little discrimination in selecting food, and swallow anything that is small enough to enter their mouths, including living animalcules, and even the sharp spicula of sponges. In some instances, however, the oral orifice is well guarded, as in pecten (fig. 10.) In the Encephala, the tongue is armed with spines, employed in the comminution of the food, and cannot possess a very delicate sense. The more ordinary and diffused sense of touch is possessed by all the mollusca; it is exercised by the skin, which is everywhere soft and lubricous, and in a higher degree by the fringes of the bivalves (fig. 12),

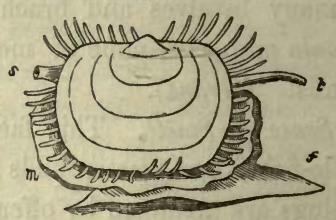

Fig. 12. Lepton Squamosum. $\dagger$ and by the filaments and tentacles (vibracula) of the gasteropods; the eye-pedicels of the snail are evidently endowed with great sensitiveness in this respect. That shell-fish are not very sensible of pain, we may well believe, on account of their tenacity of life, and the extent to which they have the power of reproducing: lost parts.

Muscular System. The muscles of the mollusca are principally connected with the skin, which is exceedingly contractile in every part. The snail affords a remarkable, though familiar

* Mr. Owen regards the membraneons lamella between the oral tentacles and in front of the mouth, as the seat of the olfactory sense. See Fig. 44.

† Fig. 12. Lepton sqaumosum Mont., from a drawing by Mr. Alder, in the British Mollusca; copied by permission of Mr. Van Voorst. 
instance, when it draws in its eye-stalks, by a process like the inversion of a glove-finger; the branching gills of some of the sea-slugs, and the tentacles of the cuttle-fishes, are also eminently contractile.*

The inner tunic of the ascidians (fig. $8, t$.) presents a beautiful example of muscular tissue, the crossing fibres having much the appearance of basket-work; in the transparent salpians, these fibres are grouped in flat bands, and arranged in characteristic patterns. In this class (tunicata) they act only as sphincters (or circular muscles), and by their sudden contraction expel the water from the branchial cavity. The muscular foot of the bivalves is extremely flexible, having layers of circular fibres for its protrusion, (fig. 18. $f$ ) and longitudinal bands for its retraction (fig. $30 \mathrm{~h}$ ); its structure and mobility has been compared to that of the human tongue. In the burrowing shell-fish (such as solen), it is very large and powerful, and in the boring species, its surface is studded with silicious particles (spicula), which render it a very efficient instrument for the enlargement of their cells. (Hancock.) In the attached bivalves it is not developed, or exists only in a rudimentary state, and is subsidiary to a gland which secretes the material of those threads with which the mussel and pinna attach themselves. (Fig. 13.) These threads are termed the byssus; the plug of the anomia, and the pedicel of terebratula are modifications of the byssus.

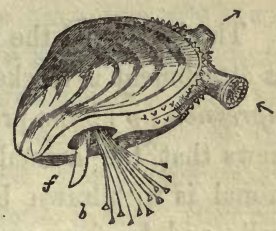

Fig. 13. Dreissena. $†$

In the cuttle-fishes alone, we find muscles attached to internal cartilages which represent the bones of vertebrate animals; the muscles of the arms are inserted in a cranial cartilage, and those of the fins in the lateral cartilages, the equivalents of the pectoral fins of fishes.

* The muscular fibres of shell-fish do not exhibit the transverse stripes which characterize voluntary muscles in the higher animals.

† Fig. 13. Dreissena polymorpha (Pallas sp.) from the Surrey timberdocks. $f$, foot. $b$, byssus. 
Muscles of a third kind are attached to the shell. The valves of the oyster (and other mono-myaries) are connected by a single muscle; those of the cytherea (and other di-myaries), by two; the contraction of which brings the valves together. They are hence named adductors; and the part of the shell to which they are attached is always indicated by scars. (Fig. 14, a. $a^{\prime}$ ).

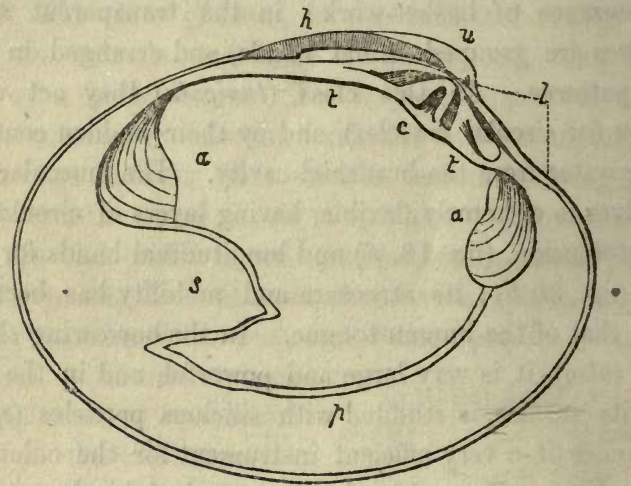

Fig. 14. Left valve of Cytherea chione.*

The border of the mantle is also muscular, and the place of its attachment is marked in the shell by a line called the pallial impression $(p)$; the presence of a bay, or sinus ( $s)$, in this line, shews that the animal had retractile siphons; the foot of the animal is withdrawn by retractor muscles also attached to the shell, and leaving small scars near those of the adductors (Fig. 30*).

The gasteropods withdraw into their shells when alarmed, by a shell-muscle, which passes into the foot, or is attached to the operculum; its impression is horse-shoe-shaped in the limpet, as also in navicella, concholepas, and the nautilus; it be-

* Fig. 14. Cytherea chione, L., coast of Devon, (original); $h$, the hinge ligament; $u$, the umbo; $l$, the lunule; $c$, cardinal tooth; $t t^{\prime}$, lateral teeth; $a$, anterior adductor; $a^{\prime}$, posterior adductor; $p$, pallial impression; $s$, sinus, occupied by retractor of the siphons. 
comes deeper with age. - In the spiral univalves, the scar is less conspicuous, being situated on the columella, and sometimes divided, forming two spots. It corresponds to the posterior retractors in the bivalves.

Digestive system. This part of the animal economy is allimportant in the radiate classes, and scarcely of less consequence in the mollusca. In the ascidians (fig. $8, i$ ), the alimentary canal is a convoluted tube, in part answering to the cesophagus, and in part to the intestine; the stomach is distinguished by longitudinal folds, which increase its extent of surface ; it receives the secretion of the liver by one or more apertures. In those bivalves, which have a large foot, the digestive organs are concealed in the upper part of that organ; the mouth is unarmed, except by two pairs of soft membranous palpi, which look like accessory gills (fig. 18. l. t.) The ciliated arms of the brachipods, occupy a similar position (figs. 4, 5, 6), and are regarded as their equivalents. The encephalous mollusca are frequently armed with horny jaws, working vertically like the mandibles of a bird; in the land-snails, the upper jaw is opposed only by the denticulated tongue, whilst the limneids have two additional horny jaws, acting laterally. The tongue is muscular, and armed with recurved spines (or lingual teeth), arranged in a great variety of patterns, which are eminently characteristic of the genera.* Their teeth are amber-coloured, glossy, and translucent; and being silicious (they are insoluble in acid), they can be used like a file, for the abrasion of very hard substances. With them the limpet rasps the stony nullipore, the whelk bores holes in other shells, and the cuttle-fish doubtless uses its tongue in the same manner as the cat. The tongue, or lingual ribbon, usually forms a triple band, of which the central part is called the rachis, and the lateral tracts pleura, the rachidian teeth

* The preparation of the lingual ribbon as a permanent microscopic object, requires some nicety of manipulation, but the arrangement of the teeth may be seen by merely compressing part of the animal between two pieces of glass. 
sometimes form a single series, overlapping each other, or there are lateral teeth on each side of a median series. The teeth on the pleuræ are termed uncini; they are extremely numerous in the plant-eating gasteropods. (Fig. 15. A.)*

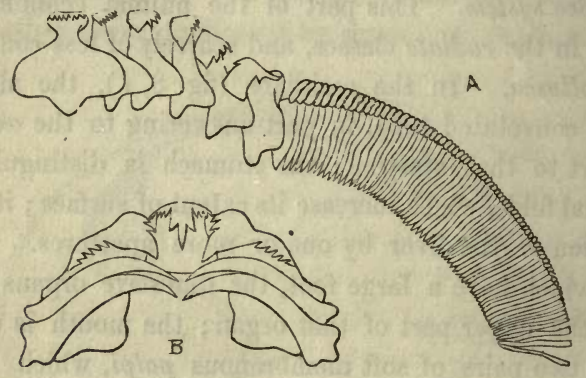

Fig. 15. Lingual Teeth of Mollusca.

-Sometimes the tongue forms a short semi-circular ridge,' contained between the jaws; at others, it is extremely elongated, and when withdrawn, its folds extend backwards to the stomach. The lingual ribbon of the limpet is longer than the whole animal; the tongue of the whelk has 100 rows of teeth; and the great slug has 160 rows, with 180 teeth in each row.

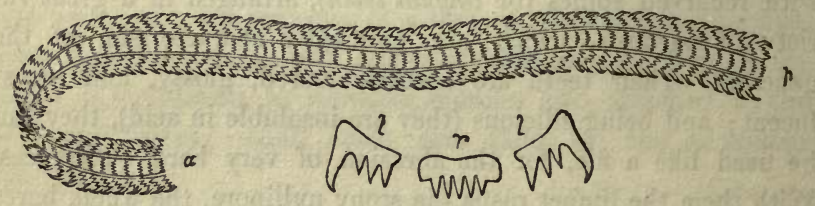

Fig. 16. Tongue of the Whelk. $\dagger$

The front of the tongue is frequently curved, or bent quite over; it is the part of the instrument in use, and its teeth are

* Fig. 15. A. Lingual teeth of trochus cinerarius (after Lorén). Only the median tooth, and the (5) lateral teeth, and (90) uncini of one side of a single row are represented. B. One row of the lingual teeth of cyproea europiaa; consisting of a median tooth, and three uncini on each side of it.

+ Fig. 16. Lingual ribbon of buccinum undatum (original), from a preparation communicated by Wm. Thomson, Esq., of King's College. 
often broken or blunted. The posterior part of the lingual ribbon usually has its margins rolled together, and united, forming a tube, which is presumed to open gradually. The new teeth are developed from behind forwards, and are brought successively into use, as in the sharks and rays amongst fishes. In the bullada the rachis of the tongue is unarmed, and the business of communicating the food is transferred to an organ which resembles the gizzard of a fowl, and is often paved with calcarions plates, so large and strong as to crush the small shell-fish which are swallowed entire. In the aplysia, which is a vegetable-feeder, the gizzard is armed with numerous small plates and spines. The stomach of some bivalves contains an instrument called the " crystalline stylet,"
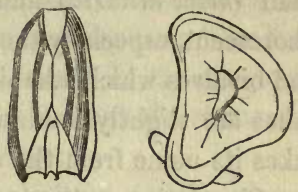
which is conjectured to have a similar use. In the cephalopods there is a crop in which the food may accumulate, as well as a gizzard for its trituration.

The liver is always large in the mollusca (fig. 10); its secretion is derived from arterial blood, and is poured either into the stomach, or the commencement of the intestine. In the nudibranchs, whose stomachs are often remarkably branched, the liver accompanies all the gastric ramifications, and even enters the respiratory papillæ on the backs of the eolids. The existence of a renal organ has been ascertained in most classes; in the bivalves it was detected by the presence of uric acid. The intestine is more convoluted in the herbivorous than in the carnivorous tribes : in the bivalves and in haliotis it passes through the ventricle of the heart; its termination is always near the respiratory aperture (or excurrent orifice, when there are

- Fig. 17. Gizzard of bulla lignaria (original). Front and side view of a half-grown specimen, with the part nearest the head of the animal down. wards; in the front view the plates are in contact. The cardiac orifice is in the centre, in front; the pyloric orifice is on the posterior dorsal side, near the small transverse plate. 
two*), and the excrements are carried away by the water which has already passed over the gills.

Besides the organs already mentioned, the encephalous mollusks are always furnished with well-developed salivary glands, and some have a rudimentary pancreas ; many have also special glands for the secretion of coloured fluids, such as the purple of the murex, the violet liquid of ianthina and aplysia, the yellow of the bullada, the milky fluid of eolis, and the inky secretion of the cuttle-fishes. A few exhale peculiar odours, like the garlicsnail (helix alliaria) and eledone moschata. Many are phosphorescent, especially the floating tunicaries (salpa and pyrosoma), and bivalves which inhabit holes (pholadida). Some of the cuttlefishes are slightly luminous ; and one land-slug, the phosphorax, takes its name from the same property.

Circulating system. The mollusca have no distinct absorbent system, but the product of digestion (chyle) passes into the general abdominal cavity, and thence into the larger veins, which are perforated with numerous round apertures. The circulating organs are the heart, arteries, and veins ; the blood is colourless, or pale bluish white. The heart consists of an auricle (sometimes divided into two), which receives the blood from the gills; and a muscular ventricle which propels it into the arteries of the body. From the capillary extremities of the arteries it collects again into the veins, circulates a second time through the respiratory organ, and returns to the heart as arterial blood. Besides this systemic heart, the circulation is aided by two additional branchial hearts in the cuttle-fishes; and by four in the brachiopoda. Mr. Alder has counted from 60 to 80 pulsations per minute in the nudibranchs, and 120 per minute in a vitrina. Both the arteries and veins form occasionally wide spaces, or

* In most of the gasteropods the intestine returns upon itself, and terminates on the right side, near the head. Occasionally it ends in a perforation more or less removed from the margin of the aperture, as in trochotoma, fissurella, macrochisma, and dentalium. In chiton the intestine is straight, and terminates posteriorly. 
sinuses; in the cuttle-fishes the œsophagus is partly or entirely surrounded by a venous sinus; and in the acephala the viceral cavity itself forms part of the circulating system.

The circulation in the tunicaries presents a most remarkable exception to the general rule, for their blood ebbs and flows in the same vessels, as it was supposed to do in the human veins before the time of Harvey. In the transparent salpa it may be seen passing from the heart into vessels connected with the viscera and tunics, and thence into the branchial vessels; but when this has continued for a time, the movement ceases, and recommences in the opposite direction, passing from the heart to the gill and thence to the system. (Lister.) In the compound tunicaries, there is a common circulation through the connecting medium, in addition to the individual currents.

Aquiferous canals. Sea-water is admitted to the visceral cavity of many of the mollusks (as it is also in radiate animals), by minute canals, opening externally in the form of pores. These aquiferous pores are situated either in the centre of the creeping disc, as in cyprca, conus, and ancillaria ; or at its margin, as in haliotis, doris, and aplysia. In the cuttle-fishes, they are variously placed, on the sides of the head, or at the bases of the arms; some of them conduct to the large sub-orbital pouches, into which the tentacles are retracted.

Respiratory system. The respiratory process consists in the exposure of the blood to the influence of air, or water containing air ; during which oxygen is absorbed and carbonic acid liberated. It is a process essential to animal life, and is never entirely suspended, even during hybernation. Those airbreathers that inhabit water are obliged to visit the surface frequently; and stale water is so inimical to the water-breathers, that they soon attempt to escape from the confinement of a glass or basin, unless the water is frequently renewed.* In general,

- When aquatic plants are kept in the same glass with water-breathing suails, a balance is produced; which enables both to live without change of water. 
fresh-water is immediately fatal to marine species, and salt-water to those which properly inhabit fresh; but there are some which affect brackish water, and many which endure it to a limited extent. The depth at which shell-fish live, is influenced by the quantity of oxygen which they require; the most active and energetic races live only in shallow water, or near the surface; those found in very deep water are the lowest in their instincts, and are specially organized for their situation. Some waterbreathers require only moist sea-air, and a bi-diurnal visit from the tide,-like the periwinkle, limpet, and kellia; whilst many air-breathers live entirely in the water or in damp places by the water-side. In fact, the nature of the respiratory process is the same, whether it be aquatic or aërial, and it is essential in each case that the surface of the breathing-organ should be preserved moist. The process is more complete in proportion to the extent and minute sub-division of the vessels, in which the circulating fluid is exposed to the revivifying influence.

The land-snails (pulmonifera), have a lung, or air-chamber, formed by the folding of the mantle, over the interior of which the pulmonary vessels are distributed; this chamber has a round orifice, on the right side of the animal, which opens and closes at irregular intervals. The air in this cavity seems to renew itself with sufficient rapidity (by the law of diffusion), without any special mechanism.

In the aquatic shell-fish, respiration is performed by the mantle, or by a portion of it specialized, and forming a gill (branchia). It is effected by the mantle alone in one family of tunicaries (pelonaiada), in all the brachiopoda, and in one family of gasteropods (actceonida).

In most of the tunicata, the breathing organ forms a distinct sac lining the muscular tunic, or mantle (fig. 8. b.); this sac has only one external aperture, and conducts to the mouth, which is situated at its base. It is a sieve-like structure, and its inner surface is clothed with vibratile cilia* which create a perpetual

* From cilium, an eyelash; they are only visible under favourable circum. 
current, setting in through the (branchial) orifice, escaping through the mesbes of the net, and passing out by the anal orifice of the outer tunics. The regularity of this current is interrupted only by spasmodic contractions of the mantle, occurring at irregular intervals, by which the creature spirts out water from both orifices, and thus clears its cavity of such accumulated particles as are rejected by the mouth; and too large to escape through the branchial pores. In the salpians, these contractions are rythmical, and have the effect of propelling them backwards. In the ordinary bivalves, the gills form two membranous plates on each side of the body ; the muscular mantle is still sometimes united, forming a chamber with two orifices, into one of which the water flows, whilst it escapes from the other; there is a third opening in front, for the foot, but this in no wise influences the branchial circulation. Some-

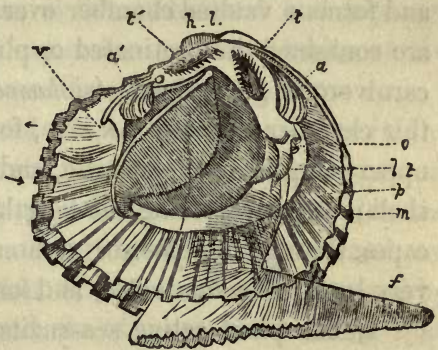

Fig. 18. Trigonia pectinata.* times the orifices are drawn out into long tubes, or siphons, especially in those shell-fish which burrow in sand. (Figs. 19 and 7.)

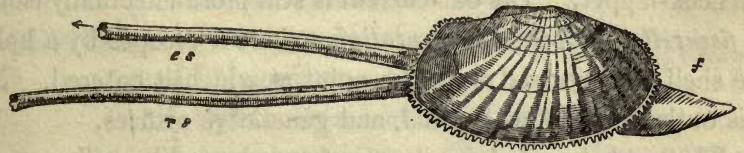

Fig. 19. Bivalve with long siphons.†

stances, with the aid of a microscope ; but the currents they canse are easily made perceptible by dropping fine sand into the water over them.

* Trigonia pectinata, Lam. (original). Bronght from Anstralia by the late Captain Owen Stanley. The gills are seen in the centre through the transparent mantle. $o$, mouth; $l t$, labial tentacles; $f$, foot ; $v$, vent.

† Fig. 19. Psammobia vespertina, Chemn. after Poli, reduced one half. The arrows indicate the direction of the current. $r s$, respiratory siphon. es, excurrent siphon. 
Those bivalves which have no siphons, and even those in which the mantle is divided into two lobes, are provided with valves or folds which render the respiratory channels just as complete in effect. These currents are not in any way connected with the opening and closing of the valves, which is only done in moving ; or in efforts to expel irritating particles.*

In some of the gasteropoda the respiratory organs form tufts, exposed on the back and sides (as in the nudibranches), or protected by a fold of the mantle (as in the inferobranches and tectibranches of Cuvier). But in most the mantle is inflected, and forms a vaulted chamber over the back of the neck, in which are contained the pectinated or plume-like gills (fig. 61). In the carnivorous gasteropods (siphonostomata) the water passes into this chamber through a siphon, formed by a prolongation of the upper margin of the mantle, and protected by the canal of the shell ; after traversing the length of the gill, it returns and escapes through a posterior siphon, generally less developed, but very long in ovulum volva, and forming a tubular spine in typhis.

In the plant-eating sea-snails (holostomata), there is no true siphon, but one of the "neck-lappets" is sometimes curled up and performs the same office, as in paludina and ampullaria (fig. 84). The in-coming and out-going currents in the branchial chamber, are kept apart by a valve-like fringe, continued from the neck-lappet. The out-current is still more effectually isolated in fissurella, haliotis, and dentalium, where it escapes by a hole in the shell, far removed from the point at which it entered. Near this outlet are the anal, renal, and generative orifices.

The cephalopods have two or four plume-like gills, symmetrically placed in a branchial chamber, situated on the under-side

* If a river-mussel be placed in a glass of water, and fine sand let fall gently over its respiratory orifices, the particles will be seen to rebound from the vicinity of the upper aperture, whilst they enter the lower one rapidly. But as this kind of food is not palatable, the creature will soon give a plunge with its foot, and closing its valves, spirt the water (and with it the sand) from both orifices; the motion of the foot is, of course, intended to change its position. 
of the body ; the opening is in front, and occupied by a funnel, which, in the nautilus, closely resembles the siphon of the paludina, but has its edges united in the cuttle-fishes. The free edge of the mantle is so adapted that it allows the water to enter the branchial chamber on each side of the funnel; its muscular walls then contract and force the water through the funnel, an arrangement chiefly subservient to locomotion.* Mr. Bowerbank has observed, that the eledone makes twenty respirations per minute, when resting quietly in a basin of water.

In most instances, the water on the surface of the gills is changed by ciliary action alone; in the cephalopods and salpians, it is renewed by the alternate expansion and contraction of the respiratory chamber, as in the vertebrate animals.

The respiratory system is of the highest importance in the economy of the mollusca, and its modifications afford most valuable characters in classification. It will be observed that the Cuvierian classes are based on a variety of particulars, and are very unequal in importance; but the orders are characterized by their respiratory conditions, and are of much more nearly equal value.

Orders.

Classes.
(Dibranchiata. Owen.
Tetrabranchiata. Owen. $\}$ CEPHALOPODA.
ENCEPHALA
Nucleobranchiata. Bl.
Prosobranchiata. M. Edw.
Pulmonifera. Cuv.
Opisthobranchiata. M. Edw.
Gasteropoda.
- Aporobranchiata. Bl.
Pteropoda.

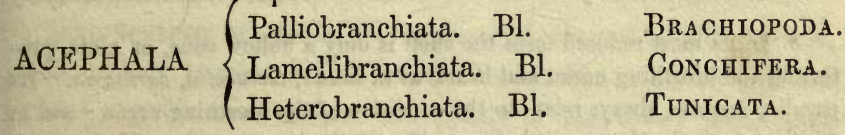

The Shell. The relation of the shell to the breathing-organ is very intimate; indeed, it may be regarded as a pneumo-skeleton,

* A very effieient means of locomotion in the slender pointed calamaries, which dart backwards with the recoil, like rockets. 
being essentially a calcified portion of the mantle, of which the breathing-organ is at most a specialised part.*

The shell is so characteristic of the mollusca that they have been commonly called "testacea" (from testa "a shell"), in scientific books; and the popular name of "shell-fish," though not quite accurate, cannot be replaced by any other epithet in common use. In one whole class, however, and in several families, there is nothing that would be popularly recognised as a shell.

Shells are said to be external when the animal is contained in them, and internal when they are concealed in the mantle; the latter, as well as the shell-less species, being called naked mollusks.

Three-fourths of the mollusca are univalve, or have but one shell; the others are mostly bivalve, or have two shells; the pholads have accessory plates, and the shell of chiton consists of eight pieces. Most of the multivalves of old authors were articulate animals (cirripedes), erroneously included with the mollusca, which they resemble only in outward appearance.

All, except the argonaut; acquire a rudimental shell before they are hatched, which becomes the nucleus of the adult shell; it is often differently shaped and coloured from the rest of the shell, and hence the fry are apt to be mistaken for distinct species from their parents.

In cymba (fig. 20) the nucleus is large and irregular; in fusus antiquus it is cylindrical ; in the pyramidellida it is oblique; and it is spiral in carinaria, atlanta, and many limpets, which are symmetrical when adult.

The rudimentary shell of the nudibranchs is shed at an early

* In its most reduced form the shell is only a hollow cone, or plate, protecting the breathing organ and heart, as in limax, testacella, carinaria. Its peculiar features always relate to the condition of the breathing-organ; and in terebratula and pelonaia it becomes identified with the gill. In the nudibranchs the vascular mantle performs wholly or in part the respiratory office. In the cephalopods the shell becomes complicated by the addition of a distinct, internal, chambered portion (phragmocone), which is properly a visceral skeleton; in spirula the shell is reduced to this part. 
age, and never replaced. In this respect the molluscan shell differs entirely from the shell of the crab and other articulate animals, which is periodically cast off and renewed.

In the bivalves the embryonic shell forms the umbo of each valve; it is often very unlike the after-growth, as in unio pictorum, cyclas henslowiana and pecten pusio. In attached shells like the oyster and anomia the umbo frequently presents an exact imitation of the surface to which the young shell originally adhered.

Shells are composed of carbonate of lime, with a small proportion of animal matter. The source of this lime is to be iooked

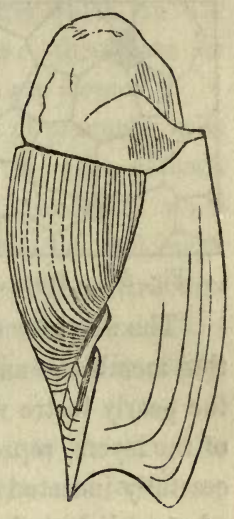

Fig. 20. Cymba.* for in their food. Modern inquiries into organic chemistry have shown that vegetables derive their elements from the mineral kingdom (air, water, and the soil), and animals theirs from the vegetable. The sea-weed filters the salt-water, and separates lime as well as organic elements; and lime is one of the most abundant mineral matters in land plants. From this source the mollusca obtain lime in abundance, and, indeed, we find frequent instances of shells becoming unnaturally thickened through the superabundance of this earth in their systems. On the other hand, instances occur of thin and delicate-shelled varieties, in still, deep water, or on clay bottoms ; whilst in those districts which are wholly destitute of lime, like the lizard in Cornwall, and similar tracts of magnesian-silicate in Asia Minor, there are no mollusca. (Forbes.)

The texture of shells is various and characteristic. Some, when broken, present a dull lustre like marble or china, and are termed porcellanous; others are pearly or nacreous; some have a fibrous structure; some are horny, and others glassy and translucent.

* Fig. 20. Cymba proboscidalis, Lam., from a very young specimen in the cabinet of Hugh Cuming, Esq., from Western Africa. 


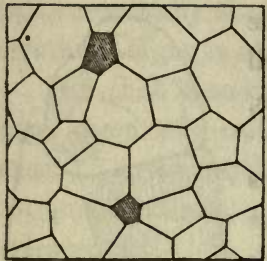

Fig. 21. Pinna.

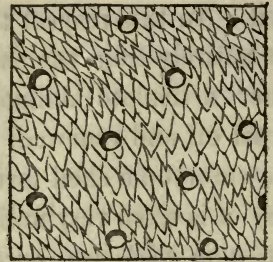

Fig. 22. Terebratula.

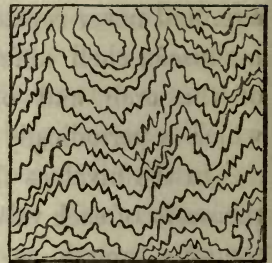

Fig. 23. Pearl.*

The nacreous shells are formed by alternate layers of very thin membrane and carbonate of lime, but this alone does not give the pearly lustre which appears to depend on minute undulations of the layers, represented in fig. 23. This lustre has been successfully imitated on engraved steel buttons. Nacreous shells, when polished, form " mother of pearl ;" when digested in weak acid, they leave a membraneous residue which retains the original form of the shell. This is the most easily destructible of shelltextures, and in some geological formations we find only casts of the nacreous shells, whilst those of fibrous texture are completely preserved.

Pearls are produced by many bivalves, especially by the Oriental pearl-mussel (avicula margaritifera), and one of the British river-mussels (unio margaritiferus). They are caused by particles of sand, or other foreign substances, getting between the animal and its shell; the irritation causes a deposit of nacre, forming a projection on the interior, and generally more brilliant than the rest of the shell. Completely spherical pearls can only be formed loose in the muscles, or other soft parts of the animal. The Chinese obtain them artificially, by introducing into the living mussel foreign substances, such as pieces of mother-of-pearl fixed to wires, which thas become coated with a more brilliant material.

- Figs. 21, 22, 23. Magnified sections of shells, from Dr. Carpenter. Fragments of shell ground very thin, and cemented to glass slides with Canada balsam, are easily prepared, and form curious microscopic objects. A great variety of them may be procured of Mr. C. M. Topping, of Pentonville. 
Similar prominences and concretions-pearls which are not pearly-are formed inside porcellanous shells; these are as variable in colour as the surfaces on which they are formed.*

The fibrous shells consist of successive layers of prismatic cells containing translucent carbonate of lime; and the cells of each successive layer correspond, so that the shell, especially when very thick (as in the fossil inoceramus and trichites), will break up vertically, into fragments, exhibiting on their edges a structure like arragonite, or satin-spar. Horizontal sections exhibit a cellular net-work, with here and there a dark cell, which is empty. (fig. 21.)

The oyster has a laminated structure, owing to the irregular accumulation of the cells in its successive layers, and breaks up into horizontal plates.

In the boring-shells (pholadida) the carbonate of lime has an atomic arrangement like arragonite, which is considerably harder than calcarious spar; in other cases the difference in hardness depends on the proportion of animal matter, and the manner in which the layers are aggregated. $\dagger$

In many bivalve shells there occurs a minute tubular structure, which is very conspicuous in some sections of pinna and oystershell.

The brachiopoda exhibit a characteristic structure by which the smallest fragment of their shells may be determined; it consists of elongated and curved cells, matted together, and often perforated by circular holes, arranged in quincunx order (fig. 22).

But the most complex shell-structure is presented by the porcellanous gasteropoda. These consist of three strata which readily separate in fossil shells, on account of the removal of their

* They are pink in turbinellus and strombus; white in ostrea; white or glassy, purple or black in mytilus; rose-coloured and translucent in pinna. (Gray.)

+ The specific gravity of floating shells (such as argonanta and ianthina) is lower than that of any others. (De la Beche.) 
animal cement. In fig. $24, a$ represents the outer, $b$ the middle, and $c$ the inner stratum; they may be seen, also, in fig. 25 .

Each of these three strata is composed of very numerous vertical plates, like cards placed on edge; and the direction of the plates is sometimes transverse in the central stratum, and lengthwise in
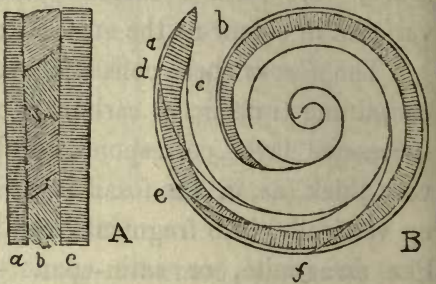

Fig. 24. Sections of a cone.* the outer and inner (as in cypraa, cassis, ampullaria, and buli$m u s)$, or longitudinal in the middle layer, and transverse in the others (e.g. conus, pyrula, oliva, and voluta).

Each plate, too, is composed of a series of prismatic cells, arranged obliquely $\left(45^{\circ}\right)$, and their direction being changed in the successive plates, they cross each other at right angles. Tertiary fossils best exhibit this structure, either at their broken edge, or in polished sections. $t$ (Bowerbank).

The argonaut-shell, and the bone of the cuttle-fish, have a peculiar structure; and the Hippurite is distinguished by a cancellated texture, unlike any other shell, except, perhaps, some of the cardiacece and chamacee.

Epidermis. All shells have an outer coat of animal matter called the "epidermis" (or periostracum), sometimes thin and transparent, at others thick and opaque. It is thick and olivecoloured in all fresh-water shells, and in many arctic sea-shells (e. g. cyprina and astarte); the colours of the land-shells often

* Sections of conus ponderosus, Brug., from the Miocene of the Touraine. A, longitudinal section of a fragment, $\mathrm{B}$, complete horizontal section; $a$, outer layer; $b$, middle; $c$, inner layer; $d, e, f$, lines of growth.

+ It is necessary to bear in mind that fossil shells are often pseudomorphous, or mere casts, in.spar or chalcedony, of cavities once occupied by shells; such are the fossils found at Blackdown, and many of the London clay fossils at Barton. The Palæozoic fossils are often metamorphic, or have undergone a re-arrangement of their particles, like the rocks in which they occur. 
depend on it; sometimes it is silky as in helix sericea, or fringed with hairs, as in trichotropis; in the whelk and some species of triton and conus it is thick and rough like coarse cloth, and in some modiolas it is drawn out into long beard-like filaments.

In the cowry and other shell-fish with large mantle lobes, the epidermis is more or less covered up by an additional layer of shell deposited externally.

The epidermis has life, but not sensation, like the human scarf-skin; and it protects the shell against the influence of the weather, and chemical agents; it soon fades, or is destroyed, after the death of the animal, in situations where, whilst living, it would have undergone no change. In the bivalves it is organically connected with the margin of the mantle.

It is most developed in shells which frequent damp situations, amongst decaying leaves, and in fresh-water shells. All freshwaters are more or less saturated with carbonic-acid gas, and in limestone countries hold so much lime in solution as to deposit it in the form of tufa on the mussels and other shells.* But in the absence of lime to neutralise the acid, the water acts on the shells, and would dissolve them entirely if it were not for their protecting epidermis. As it is we can often recognise fresh-water shells by the erosion of those parts where the epidermis was thinnest, namely, the points of the spiral shells and the umbones of the bivalves, those being also the parts longest exposed. Specimens of melanopsis and bithinia become truncated again and again in the course of their growth, until the adults are sometimes only half the length they should be, and the discoidal planorbis sometimes becomes perforated by the removal of its inner whirls; in these cases the animal closes the break in its shell with new layers. Some of the unios thicken their umbones enormously, and form a layer of animal matter with each new layer of shell, so that the river-action is arrested at a succession of steps.

* As at Tisbury, in Wiltshire, where remarkable specimens of anodons were obtained by the late Miss Benett. 


\section{FORMATION AND GROWTH OF THE SHELL.}

The shell, as before stated, is formed by the mantle of the shell-fish, indeed, each layer of it was once a portion of the mantle, either in the form of a simple membrane, or as a layer of cells; and each layer was successively calcified (or hardened with carbonate of lime) and thrown off by the mantle to unite with those previously formed. Being extra-vascular it has no inherent power of repair. (Carpenter.)

The epidermis and cellular structures are formed by the margin (or collar) of the mantle; the membranous and nacreous layers, by the thin and transparent portion which contains the viscera; hence we find the pearly texture only as a lining inside the shell, as in the nautilus, and all the aviculida and turbinida.

If the margin of a shell is fractured during the life-time of the animal, the injury will be completely repaired by the reproduction both of the epidermis and of the outer layer of shell with its proper colour. But if the apex is destroyed, or a hole made at a distance from the aperture, it will merely be closed with the material secreted by the visceral mantle. Such inroads are often made by boring worms and shells, and even by a sponge (cliona) which completely mines the most solid shells. In Mr. Gray's cabinet is the section of a cone, in whose apex a colony of lithodomi

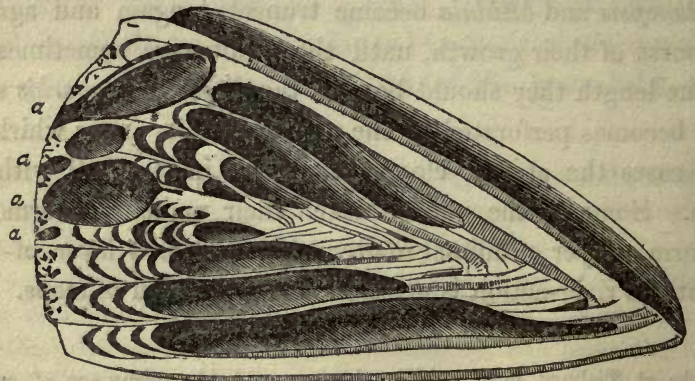

Fig. 25. Section of a cone perforated by lithodomi. 
had settled, compelling the animal to contract itself, faster even than it could form shell to fill up the void.

Iines of growth. So long as the animal continues growing, each new layer of shell extends beyond the one formed before it; and, in consequence, the external surface becomes marked with lines of growth. During winter, or the season of rest which corresponds to it, shells cease to grow ; and these periodic restingplaces are often indicated by interruptions of the otherwise regular lines of growth and colour, or by still more obvious signs. It is probable that this pause, or cessation from growth, extends into the breeding season; otherwise there would be two periods of growth, and two of rest in each year. In many shells the growth is uniform; but in others each stage is finished by the development of a fringe, or ridge (varix), or of a row of spines, as in tridacna and murex. (Owen, Grant.)

Adult characters. The attainment of the full-growth proper to each species is usually marked by changes in the shell.

Some bivalves, like the oyster, and gryphea (fig. 26), continue to increase in thickness long after they have ceased to grow outwards;

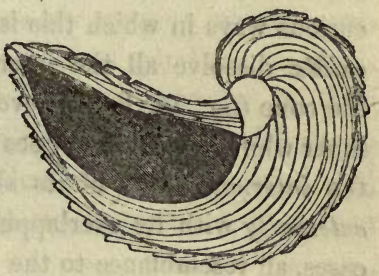

Fig. 26. Section of gryphoea.* the greatest addition is made to the lower valve, especially near the umbo; and in the spondylus some parts of the mantle secrete more than others, so that cavities, filled with fluid, are left in the substance of the shell.

The adult teredo and fistulana close the end of their burrows; the pholadidea fills up the great pedal opening of its valves; and the aspergillum forms the porous disk from which it takes its name. Sculptured shells, particularly ammonites, and species of rostellaria and fusus, often become plain in the last part of their

* Fig. 26. Section of gryphcea incurva, Sby. Lias, Dorset, (original ; diminished one half), the upper valve is not much thickened; the interior is filled with lias. 
growth. But the most characteristic change is the thickening and contraction of the aperture in the univalves. The young cowry (fig. 27) has a thin, sharp lip, which becomes curled inwards, and enormously thickened and toothed in the adult; the pteroceras (pl. 4, fig. 3) developes its scorpion-like claws, only when fullgrown; and the land-snails form a thickened lip, or narrow their aperture with projecting processes, so that it is a marvel how they pass in and out, and how they can exclude their eggs, (e. g. pl. 12, fig. 4, anastoma; and fig. 5, helix

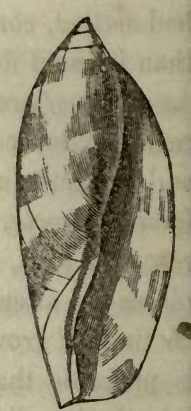
hirsuta).

Yet at this time they would seem to require more space and accommodation in their houses than before, and there are several curious ways in which this is obtained. The neritida and auri. culida dissolve all the internal spiral columnt of their shells the cone (fig. 24, B,) removes all but a paper-like portion of its inner whirls; the cowry goes still further, and continues removing the internal layers of its shell-wall, and depositing new layers externally with its overlapping mantle (fig. 76), until, in some cases, all resemblance to the young shell is lost in the adult.

The power which mollusks possess of dissolving portions of their own shells, is also exhibited by the murices, in removing those spines from their whirls which interfere with their growth; and by the purpurce and others in wearing away the wall of their aperture. The agency in these cases is supposed to be chemical.

Decollated shells. It frequently happens that as spiral shells become adult they cease to occupy the upper part of their cavity ; the space thus vacated is sometimes filled with solid shell, as in magilus; or it is partitioned off, as in vermetus, euomphalus, turritella and triton (fig. 62). The deserted apex is sometimes very thin, and becoming dead and brittle, it breaks away, leaving

* Cyprea testudinaria, L., young.

$\uparrow$ This is sometimes done by the hermit-era' to the shells it occupies. 
the shell truncated, or decollated. This happens constantly with the truncatella, cylindrella, and bulimus decollatus; amongst the fresh-water shells it depends upon local circumstances, but is very common with pirena and cerithidea.

Forms of shells. These will be described particularly under each class; enough has been said to show that in the molluscan shell (as in the vertebrate skeleton) indications are afforded 0 many of the leading affinities and structural peculiarities of the animal. It may sometimes be difficult to determine the genus of a shell, especially when its form is very simple; but this results more from the imperfection of our technicalities and systems, than from any want of co-ordination in the animal and its shell.

Monstrosities. The whirls of spiral shells are sometimes separated by the interference of foreign substances, which adhere to them when young; the garden-snail has been found in this condition, and less complete instances are common amongst seashells. Discoidal shells occasionally become spiral (as in specimens of planorbis found at Rochdale), or irregular in their growth, owing to an unhealthy condition. The discoidal ammonites sometimes show a slight tendency to become spiral, and more rarely become unsymmetrical, and have the keel on one side, instead of in the middle.

All attached shells are liable to interference in their growth, and malformations consequent on their situation in cavities, or from coming in contact with rocks. The dreissena polymorpha distorts the other fresh-water mussels by fastening their valves with its byssus; and balani sometimes produce strange protuberances on the back of the cowry, to which they have attached themselves when young.*

In the miocene tertiaries of Asia Minor, Professor Forbes

* In the British Museum there is a helix terrestris (chemn.) with a small stick passing through it, and projecting from the apex and umbilicus. Mr. Pickering has, in his collection, a helix hortensis which got entangled in a nutshell when young, and growing too large to escape, bad to endure the incubus to the end of its days. 
discovered whole races of neritina, paludina, and melanopsis, with whirls ribbed or keeled, as if through the unhealthy influence of brackish water. The fossil periwinkles of the Norwich Crag are similarly distorted, probably by the access of fresh-water; parallel cases occur at the present day in the Baltic.

Reversed shells. Left-handed, or reversed varieties of spiral shells have been met with in some of the very common species, like the whelk and garden-snail. Bulimus citrinus is as often sinistral as dextral; and a reversed variety of fusus antiquus was more common than the normal form in the pliocene sea. Other shells are constantly reversed, as pyrula perversa, many species of pupa, and the entire genera, clausilia, cylindrella, physa, and triphoris. Bivalves less distinctly exhibit variations of this kind; but the attached valve of chama has its umbo turned to the right or left indifferently; and of two specimens of lucina childreni in the British Museum, one has the right, the other the left valve flat.

The colours of shells are usually confined to the surface beneath the epidermis, and are secreted by the border of the mantle, which often exhibits similar tints and patterns (e.g. voluta undulata, fig. 73). Occasionally the inner strata of porcellanous shells are differently coloured from the exterior, and the makers of shellcameos avail themselves of this difference to produce white or rose-coloured figures on a dark ground.*

The secretion of colour by the mantle depends greatly on the action of light; shallow-water shells are, as a class, warmer and brighter coloured than those from deep water; and bivalves which are habitually fixed or stationary (like spondylus and pecten pleuronectes) have the upper valve richly tinted, whilst the lower one is colourless. The backs of most spiral shells are darker

- Cameos in the British Museum, carved on the shell of cassis cornuta, are white on an orange ground; on c. tuberosa, and madagascariensis, white upon dark claret-colour; on $c$. rufa, pale salmon-colour on orange; and on strombus gigas, yellow on pink. By filing some of the olives (e. g. oliva utriculus) they may be made into very different coloured shells. 
than the under sides; but in ianthina the base of the shell is habitually turned upwards, and is deeply dyed with violet. Some colours are more permanent than others; the red spots on the naticas and nerites are commonly preserved in tertiary and oolitic fossils, and even in one example (of $n$. subcostata schl.) from Devonian limestone. Terebratula hastata, and some pectens of the carboniferous period, retain their markings; the orthoceras anguliferus of the Devonian beds has zig-zag bands of colour; and a terebratula of the same age, from arctic North America,* is ornamented with several rows of dark red spots.

The operculum. Most spiral shells have an operculum, or lid, with which to close the aperture when they withdraw for shelter (see gasteropoda). It is developed on a particular lobe at the posterior part of the foot, and consists of horny layers, some

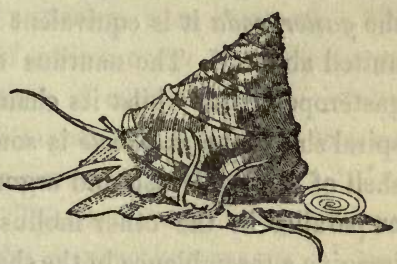

Fig. 28. Trochus zisiphinus. $\dagger$ times hardened with shelly matter (fig. 28).

It has been considered by Adanson, and more recently by Mr. Gray, as the equivalent of the dextral valve of the conchifera; but however similar in appearance, its anatomical relations are altogether different. In position it represents the byssus of the bivalves (Lovén); and in function it is like the plug with which unattached specimens of bysso-arca close their aperture. (Forbes.)

Homologies of the shell. $\$$ The shell is so simple a structure that its modifications present few points for comparison; but even these are not wholly understood, or free from doubt. The

- Presented to the British Museum by Sir John Richardson.

+ Trochus ziziphinus, from the original, taken in Pegwell Bay abundantly. This species exhibits small tentacular processes, neck-lappets, side-lappets, entacular filaments, and an operculigerous lobe.

‡ Parts which correspond in their real nature-(their origin and developnent) -are termed homologous; those which agree merely in appearanee, or uffice, are said to be analogous. 
bivalve shell may be compared to the outer tunic of the ascidian, cut open and converted into separable valves. In the conchifera this division of the mantle is vertical, and the valves are right and left. In the brachiopoda the separation is horizontal, and the valves are dorsal and ventral. The monomyarian bivalves lie habitually on one side (like the pleuronectida among fishes); and their shells, though really right and left, are termed "upper" and "lower" valves. The univalve shell is the equivalent of both valves of the bivalve. In the pteropoda it consists of dorsal and ventral plates, comparable with the valves of terebratula. In the gasteropoda it is equivalent to both valves of the conchifera united above.* The nautilus shell corresponds to that of the gasteropod; but whilst its chambers are shadowed forth in many spiral shells, the siphuncle is something additional ; and the entire shell of the cuttle-fish and argonaut $†$ have no known equivalent or parallel in the other molluscous classes. The student might imagine a resemblance in the shell of the orthoceras to a back-bone; but the true homologue of the vertebrate skeleton is found in the neural and muscular cartilages of the cephalopod; whilst its phragmocone is but the representative of the calcarious axis (or splanchno-skeleton) of a coral, such as amplexus or siphonophyllia.

Temperature and hybernation. Observations on the temperature of the mollusca are still wanted; it is known, however, to vary with the medium in which they live, and to be sometimes a degree or two higher or lower than the external temperature; with snails (in cool weather), it is generally a degree or two higher.

The mollusca of temperate and cold climates are subject to hybernation; during which state the heart ceases to beat, respira-

- Compare fissurella or trochus (fig. 28) with lepton squamosum (fig. 12). The disk of hipponyx is analogous to the ventral plate of hyalæa and terebratula.

† The argonaut shell is compared by Mr. Adams to the nidamental capsules of the whelk; a better analogue would have been found in the raft of the ianthina, which is secreted by the foot of the animal, and serves to float the egg-capsules. 
tion is nearly suspended, and injuries are not healed. They also astivate, or fall into a summer sleep when the heat is great; but in this the animal functions are much less interrupted. (Muller.)

Reproduction of lost parts. It appears from the experiments of Spallanzani, that snails, whose ocular tentacles have been destroyed, reproduce them completely in a few weeks; others have repeated the trial with a like result. But there is some doubt whether the renewal takes place if the brain of the animal be removed as well as its horns. Madame Power has made similar observations upon various marine snails, and has found that portions of the foot, mantle, and tentacles, were renewed. Mr. Hancock states that the species of eolis are apt to make a meal off each other's branchia, and that, if confined in stale water, they become sickly and lose those organs; in both cases they are quickly renewed under favourable circumstances.

Reproduction by gemmation. The social and compound tunicaries resemble zoophytes, in the power they possess of budding out new individuals, and thus of multiplying their communities indefinitely, as the leaves on a tree. This gemmation takes place only at particular points, so that the whole assemblages are aggregated in characteristic patterns. The buds of the social tunicaries are supported at first by their parents, those of the compound families by the general circulation, until they are in a state to contribute to the common weal.

Viviparous reproduction. This happens in a few species of gastropods, through the retention of the eggs in the oviduct, until the young have attained a considerable growth. It also appears to take place in the acephalans, because their eggs generally remain within some part of the shell of the parent until hatched.

Alternate generation. Amongst the tunicaries an example is found of regulated diversity in the mode of reproduction. The salpians produce long chains of embryos, which, unless broken by accident, remain connected during life;-cach individual of these compound specimens produces solitary young, often so un- 
like the parent as to have been described and named by naturalists as distinct species; - these solitary salpians again produce chains of embryos, like their grand-parents. (Chamisso.)

Oviparous reproduction. The sexes are distinct in the most highly organised (or dicecious) mollusca; they are united in the (monocious) land-snails, pteropods, brachiopods, tunicaries, and in part of the conchifers. The prosobranchs pair; but in the diœcious acephalans and cuttle-fishes, the spermatozoa are merely discharged into the water, and are inhaled with the respiratory currents by the other sex. The monœcious land-snails require reciprocal union; the limneîds unite in succession, forming floating chains.

The eggs of the land-snails are separate, and protected by a shell, which is sometimes albuminous and flexible, at others calcarious and brittle; those of the fresh-water species are soft, mucous, and transparent. The spawn of the sea-snails consists of large numbers of eggs, adhering together in masses, or spread out in the shape of a strap or ribbon, in which the eggs are arranged in rows; this nidamental ribbon is sometimes coiled up spirally, like a watch-spring, and attached by one of its edges.

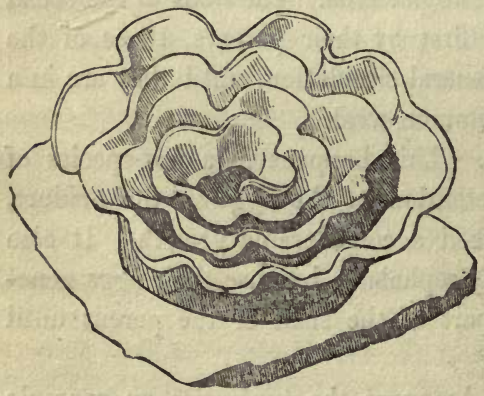

Fig. 29. Spawn of Doris.*

The eggs of the carnivorous gasteropods are inclosed in tough albuminous capsules, each containing numerous germs; these are deposited singly, or in rows, or agglutinated in groups, equallingtheparent animal in bulk (fig. 70) The nidamental capsulcs of the cuttle-fish are clus. tered like grapes, each containing but one embryo; those of the calamary are groupee 
in radiating masses, each elongated capsule containing 30 or 40 ova. The material with which the eggs are thus cemented together, or enveloped, is secreted by the nidamental gland, an organ largely developed in the female gasteropods and cephalopods (fig. $43, \mathrm{n}$ ).

Development. The molluscan ovum consists of a coloured yolk (vitellus), surrounded by albumen. On one side of the yolk is a pellucid spot, termed the germinal vesicle, having a spot or nucleus on its surface. This germinal vesicle is a nucleated cell, capable of producing other cells like itself; it is the essential part of the egg, from which, the embryo is formed; but it undergoes no change without the influence of the spermatozoa.* After impregnation, the germinal vesicle, which then subsides into the centre of the yolk, divides spontaneously into two; and these again divide and subdivide into smaller and still smaller globules, each with its pellucid centre or ntcleus, until the whole presents a uniform granular appearance. The next step is the formation of a ciliated epithelium on the surface of the embryonic mass; movements in the albumen become perceptible in the vicinity of the cilia, and they increase in strength, until the embryo begins to revolve in the surrounding fluid. $\dagger$

* No instance of "partheno-genesis" is known among the mollusca; the most "equivocal" case on record is that related by Mr. Gaskoin. A specimen of helix lactea, Müll., from the South of Europe, after being two years in his cabinet, was discovered to be still living; and ou being removed to a plant-case it revived, and six weeks afterwards had produced twenty young ones!

+ According to the observations of Professor Lovén (on certain biralve mollusea), the ova are excluded immediately after the inhalation of the spermatozoa, and apparently from their influence; but impregnation does not take place within the ovary itself. The spermatozoa of cardium pygmaum were distinctly seen to penetrate, in succession, the outer envelopes of the ova, and arrive at the vitellus, when they disappeared. With respect to the "germinal vesicle;" according to Barry, it first approaches the inner surface of the vitelline membrane, in order to receive the influence of the spermatozoa; it then retires to the centre of the yolk, and undergoes a series of spontaneous subdivisions. In M. Lovén's account, it is said to "burst" and par- 
Up to this point nearly the same appearances are presented by the eggs of all classes of animals, - they manifest, so far, a complete " unity of organization." In the next stage, the development of an organ, fringed with stronger cilia, and serving both for locomotion and respiration, shews that the embryo is a molluscous animal; and the changes which follow soon point out the particular class to which it belongs. The rudimentary head is early distinguishable, by the black eye-specks; and the heart, by its pulsations. The digestive and other organs are first "sketched out," then become more distinct, and are seen to be covered with a transparent shell. By this time the embryo is able to move by its own muscular contractions, and to swallow food; is is therefore "hatched," or escapes from the egg.

The embryo tunicary quits the egg in the cloacal cavity of its parent, and is at this time provided with a swimming instrument, like the tail of the tadpole, and with processes by which it attaches itself as soon as it finds a suitable situation.

The young bivalves also are hatched before they leave their

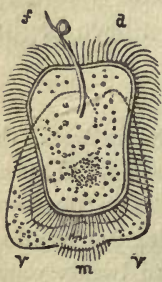

Fig. 30.* parent, either in the gill cavity or in a special sac attached to the gills (as in cyclas), or in the interspaces of the external branchial laminæ (as in unio). At first they have a swimming disk, fringed with long cilia, and armed with a slender tentacular filament (flagellum). At a later period this disk disappears progressively, as the labial palpi are developed; and they acquire a foot, and with it the power of spinning a byssus. They now

tially dissolve, whilst the egg remains in the ovary, and before impregnation; it then passes to the centre of the yolk, and undergoes the changes described by Barry, along with the yolk, whilst the nucleus of the germinal vesicle, or some body exactly resembling it, is seen occupying a small prominence on the surface of the vitelline membrane, until the metamorphosis of the yolk is completed, when it disappears, in some unobserved manner, without fulfilling any recognized purpose.

* Fig. 30. Very young fry of crenella marmorata, Forbes, highly magnified; $d$, disk, bordered with cilia : $f$, flagellum; $v v$, valves; $m$, ciliated mantle. 
have a pair of eyes, situated near the labial tentacles (fig. $30 *, e$ ), which are lost at a further stage, or replaced by numerous rudimentary organs placed more favourably for vision, on the border of the mantle.

Most of the aquatic gasteropoda are very minute when hatehed, and they enter life under the same form, - that which

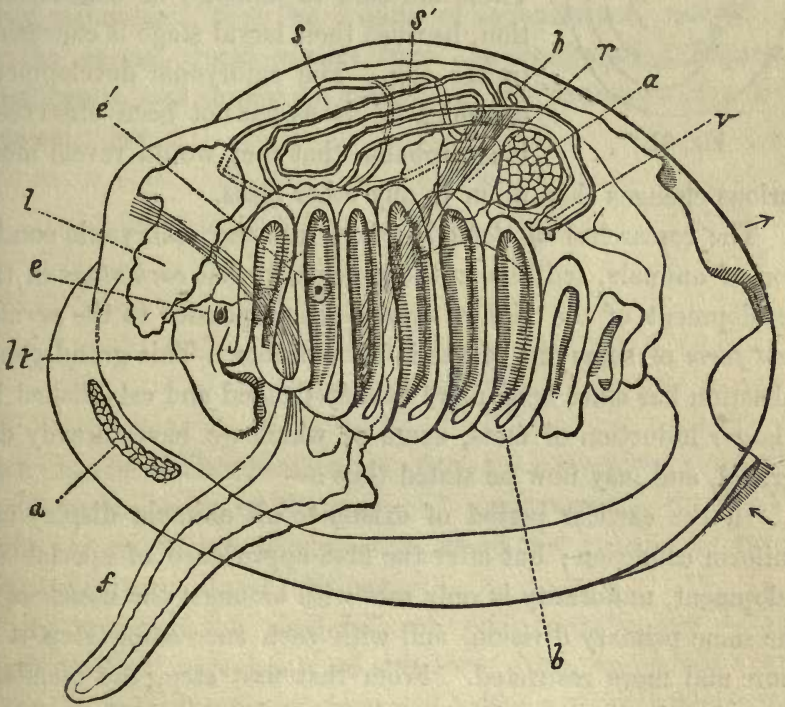

Fig. 30*. Fry of the Mussel.*

has been already referred to as permanently characteristic of the pteropoda. (Fig. 60.)

The Pulmonifera and Cephalopoda produce large eggs, con-

* Fig. 30*. Fry of mytilus edulis, after Lovén. $e$, eye; $e^{\prime}$, auditory capsule; $l t$, labial tentacles; $s s^{\prime}$, the stomach; $b$, branchix; $h$, heart; $v$, vent; $l$, liver; $r$, renal organ; $a$, anterior adductor; $a^{\prime}$, posterior adductor; $f$, foot. The arrows indicate the incurrent and excurrent openings; between which the margins of the mantle are united in the fry. 
taining sufficient nutriment to support the embryo until it has

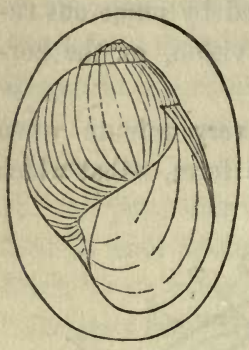

Fig. 31.* attained considerable size and development; thus, the newly-born cuttle-fish has a shell half an inch long, consisting of several layers, and the bulimus ovatus has a shell an inch in length when hatched. (Fig. 31.) These are said to undergo no transformation, because their larval stage is concealed in the egg. The embryonic development of the cuttle-fishes has not been observed; it is probable that they would reveal more curious changes than occur in any other class.

The researches of John Hunter t into the embryonic condition of animals, led him to the conclusion that each stage in the development of the highest animals corresponded to the permanent form of some one of the inferior orders. This grand generalisation has since been more exactly defined and established by a larger induction of facts, some of which we have already described, and may now be stated thus:-

In the earliest period of existence all animals display one uniform condition; but after the first appearance of special development, uniformity is only met with amongst the members of the same primary division, and with each succeeding step it is more and more restricted. From that first step, the members of each primary group assume forms and pass through phases which have no parallels, except in the division to which each belongs. The mammal exhibits no likeness, at any period, to the adult mollusk, the insect, or the star-fish; but only to the

* Egg and young of bulimus ovatus, Mall. sp., Brazil, from specimens in the collection of Hugh Cuming, Esq.

† "In his printed works the finest elements of system seem evermore to flit before him, twice or thrice only to have been seized, and after a momentary detention to have been again suffered to escape. At length, in the astonishing preparations for his museum, he constructed it, for the scientific apprehension, out of the unspoken alphabet of nature." (Caleridge.) 
ovarian stage of the invertebrata, and to more advanced stages of the classes formed upon its own type. And so also with the highest organized mollusca; after their first stage they resemble the simpler orders of their own sub-kingdom, but not those of any other group.

These are the views of Professor Owen-the successor of Hunter-by whom it has been most clearly shewn and steadfastly maintained, that the "unity of organization" manifested by the animal world results from the design of a Supreme Intelligence, and cannot be ascribed to the operation of a mechanical "law."

\section{Chapter V. \\ CLASSIFICATION.}

THE objects of classification are, first, the convenient and intelligible arrangement of the species;* and, secondly, to afford a summary, or condensed exposition, of all that is known respecting their structure and relations.

In studying the shell-fish, we find resemblances of two kinds. First, agreements of structure, form, and habits; and, secondly, resemblances of form and liabits without agreement of structure. The first are termed relations of affinity; the second of analogy.

Affinities may be near, or remote. There is some amount of affinity common to all animals; but, like relationships amongst men, they are recognized only when tolerably close. Resemblances of structure which subsist from a very early age are presumed to imply original relationship; they have been termed

* At least 12,000 recent, and 15,000 fossil species of molluscous animals are known. 
genetic (or histological), and are of the highest importance. Those which are superinduced at a later period, are of less consequence.

Analogies. Modifications relating only to peculiar habits are called adaptive; or teleological, from their relation to final causes.* A second class of analogical resemblances are purely external and illusive; they have been termed mimetic (Strickland), and, by their frequency, almost justify the notion that a certain set of forms and colours are repeated, or represented in every class and family. In all artificial arrangements, these mimetic resemblances have led to the association of widely different animals in the same groups. $\dagger$ Particular forms are also represented geographically $\$$ and geologically, $\S$ as well as systematically.

In all attempts to characterise groups of animals, we find, that in advancing from the smaller to the larger combinations, many of the most obvious external features become of less avail, and we are compelled to seek for more constant and comprehensive signs in the phases of embryonic development, and the condition of the circulating, respiratory, and nervous systems.

Species. All the specimens, or individuals, which are so much alike that we may reasonably believe them to have descended from a common stock, constitute a species. It is a particular provision for preventing the blending of species, that hybrids are always barren; and it is certain, in the case of shells, that a great many kinds have not changed in form, from the tertiary

- For example, the paper nautilus, from its resemblance to carinaria, was long supposed to be the shell of a nucleobranche, parasitically occupied by the "ocythöe."

† E. g. Aporrhaïs with strombus, and ancylus with patella.

\$ Monoceros imbricatum and buccinum antarcticum take the place, in South America, of our common whelk and purple, and solen gladiolus and solen americanus of our solen siliqna and ensis.

\$ The frequent recurrence of similar species in successive strata may lead beginners to attribute too much to the influence of time and external circumstances; but such impressions disappear with further experience. 
period to the present day, - a lapse of many thousand years, and through countless generations. When individuals of the same brood differ in any respect, they are termed varieties; for example, one may be more exposed to the light, and become brighter coloured; or it may find more abundant food, and grow larger than the rest. Should these peculiarities become permanent at any place, or period,-should all the specimens on a particular island or mountain, or in one sea, or geological formation, differ from those found elsewhere,-such permanent variety is termed a race; just as, in the human species, there are white and coloured races. The species of some genera are less subject to variation than others; the nucula, for example, although very numerous, are always distinguishable by good characters. Other genera, like ammonites, terebratula, and tellina, present a most perplexing amount of variation, resulting from age, sex, supply of food, variety of depth, and of saltness in the water. And further, whilst in some genera every possible variety of form seems to have been called into existence, in others only a few, strikingly distinct forms, are known.

Genera are groups of species, related by community of structure in all essential respects. The genera of bivalves have been characterised by the number and position of their hinge-teeth; those of the spiral univalves, by the form of their apertures; but these technical characters are only valuable so far as they indicate differences in the animals themselves.

Families are groups of genera, which agree in some more general characters than those which unite species into genera. Those which we have employed are mostly modifications of the artificial families framed by Lamarck, a plan which seemed more desirable, in the present state of our knowledge, than a subdivision into very numerous families, without assignable characters.

The orders and classes of mollusca have already been referred to; those now in use are all extremely natural.

It has been sometimes asserted that these groups are only scientific contrivances, and do not really exist in nature; but 
this is a false as well as a degrading view of the matter. The labours of the most eminent systematists have been directed to the discovery of the subordinate value of the characters derivable from every part of the animal organization; and, as far as their information enabled them, they have made their systems expressive " of all the highest facts, or generalisations, in natural history." (Owen.)

M. Milne Edwards has remarked, that the actual appearance of the animal kingdom is not like a well-regulated army, but like the starry heavens, over which constellations of various magnitude are scattered, with here and there a solitary star which cannot be included in any neighbouring group.

This is exceedingly true; we cannot expect our systematic groups to have equal numerical values, * but they ought to be of equal structural importance; and they will thus possess a symmetry of order, which is superior to mere numerical regularity.

All the most philosophic naturalists have entertained a belief that the development of animal forms has proceeded upon some regular plan, and have directed their researches to the discovery of that "reflection of the divine mind." Some have fancied that they have discovered it in a mystic number, and have accordingly converted all the groups into fives. $t$ We do not undervalue these speculations, yet we think it better to describe things so far only as we know them.

Great difficulty has always been found in placing groups according to their affinities. This cannot be effected in-the way in which we are compelled to describe them - a single series; for each group is related to all the rest; and if we extend the representation of the affinities to very small groups, any arrange-

* The numerical development of groups is inversely proportional to the bulk of the individuals composing them. (Waterhouse.)

+ The quinarians make out five molluscous classes, by excluding the tunicata; the same end would be attained in a more satisfactory manner by reducing the pteropods to the rank of an order, which might be placed next to the opistho-branches. 
ment ou a plane surface would fail, for the affinities radiate in all directions, and the "net-work" to which Fabricius likened them, is as insufficient a comparison as the "chain" of older writers.*

\section{Chapter VI. \\ NOMENCLATURE.}

THE practice of using two names-generic and specific-for each animal, or plant, originated with Linnæus; therefore no scientific names date further back than his works. In the construction of these names, the Greek and Latin languages are preferred, by the common consent of all countries.

Synonyms. It often happens that a species is named, or a genus established, by more than one person, at different times, and in ignorance of each other's labours. Such duplicate names are called synonyms; they have multiplied amazingly of late, and are a stumbling-block and an opprobium in all branches of natural history. $\dagger$

* The quinary arrangement of the molluscous classes reminds us of the eastern emblem of eternity - the serpent holding its tail in its mouth.

The following diagram is offered as an improved circular system:-

[Fishes.]

Di-branchiata.

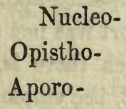

Pallio-

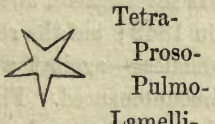

Lamelli-

Hetero-branchiata.

[ZoOpHYTES.]

+ In Pfeiffer's Monograph of the Helicida, a family containing seventeeu genera, no less than 330 generic synonyms are enumerated; to this list, ni. Albers, of Berlin, has lately added another hundred of his own invention! 
One very common estuary shell rejoices in the following variety of titles:-

Scrobicularia piperata (Gmelin sp).
Trigonella plana (Da Costa).
Mactra Listeri (Auct).
Mya Hispanica (Chemnitz).
Venus borealis (Pennant).
Lutraria compressa (Lamarck).
Arenaria plana (Megerle).

As regards specific names, the earliest ought certainly to be adopted,-with, however, the following exceptions:-

1. MS. names; which are only admitted by courtesy.

2. Names given by writers antecedent to Linnæus.

3. Names unaccompanied by a description or figure.

4. Barbarisms ; or names involving error or absurdity,*

It is also very desirable that names having a general (European) acceptation, should not be changed, on the discovery of earlier names in obscure publications.

With respect to genera, - those who believe in their real existence, as "ideas of the creating mind," will be disposed to set aside many random appellations, given to particular shells without any clear enunciation of their characters ; and to adopt later names, if bestowed with an accurate perception of the grounds which entitle them to generic distinction. $\dagger$

Authority for specific names. The multiplication of synonyms having made it desirable to place the authority after each

* This subject was investigated, and reported npon, by a committee of the British Association, in 1842; but the report was not sufficiently circulated.

+ Several bad practices-against which there is, unhappily, no lawshould be strongly discountenanced. First, the employment of names already in familiar use for other objects; such as cidaris (the title of a well-known genus of sea-urchins), for a group of spiral shells; and arenaria (a property of the botanists), for a bivalve. Secondly, the conversion of specific into generic titles, a process which has caused endless confusion; it has arisen out of the vain desire of giving new designations to old and familiar objects, and thus obtaining a questionable sort of fame. 
name, another source of evil has arisen; for several naturalists (fancying that the genus-maker, and not the species-maker, should enjoy this privilege) have altered or divided almost every genus, and placed their signatures as the authorities for names given half a century or a century before, by LiNNAUS or BRUGUIERE.* British naturalists have disowned this practice, and agreed to distinguish, by the addition of "sp.," the authorities for those specific names whose generic appellations have been changed.

Types. The type of each genus should be that species in which the characters of its group are best exhibited, and most evenly balanced. (Waterhouse.) It has, however, been customary to take as the type, that species which the genus-maker placed first on his list; although by so doing there is risk of adopting an aberrant form, or one which very feebly represents the group, of which it is an obscure member.

* The authorities appended to specific names, are supposed to indicate an amount of work done in the determination and description of the species; when, therefore, the real author's name is suppressed, and a spurious one substituted, the case looks very like an attempt to obtain credit under false pretences.

\section{ABBREVIATIONS.}

Etym., etymology. Syn., synonym. Distr., distribution.

M.S., manuscript, i. e., unpublished.

Sp., species. Brit. M., (in the) British Museum.

Distr., Norway-New Zcaland; including all intermediate seas.

Fossil, lias-chalk; implies that the genus existed in these, and all intervening strata. Chalk -; means that the genus commenced in the chalk, and has existed ever since.

Depth; - $50 \mathrm{fms}$; genus found at all depths between low-water and 50 fathoms. A fathom is six feet.

$\frac{1}{4}$ one-fourth the real size ; $\frac{4}{1}$ magnified four times.

Lat., breadth. Long., length. Alt., height or thickness.

Unc., (uncia) an inch. Lin., (linea) a line, the $\frac{1}{12}$ of an inch.

Mill., millimetre, the twenty-fifth part of an inch. 


\section{MANUAL OF THE MOLLUSCA.}

\section{CLASS I. CEPHALOPODA.}

THE cuttle-fishes, though excluded by dealers from the list of shell-fish, are the most remarkable, and, rightly considered, the most interesting of any; whilst their relatives, the nautili and ammonites, are unmatched for the symmetry and wondrous architecture of their pearly shells.

The principal locomotive organs of the cephalopods, are attached to the head, in the form of muscular arms or tentacles ; ${ }^{*}$ in addition to which, many have fins; and all can propel themselves by the forcible expulsion of water from their respiratory chamber.

Unlike most of the mollusca, they are symmetrical animals, having their right and left sides equally developed; and their shell is usually straight, or coiled in a vertical plane. The nautilus and argonaut alone (of the living tribes) have external shells ; the rest are termed "naked cephalopods," because the shell is interual. They have powerful jaws, acting vertically, like the mandibles of birds; the tongue is large and fleshy, and part of its surface is sentient, whilst the rest is armed with recurved spines; their eyes are large, and placed on the sides of the head; their senses appear to be very acute. All are marine; and predatory, living on shell-fish, crabs, and fishes.

The nervous system is more concentrated than in the other mollusca; and the brain is protected by a cartilage. The respiratory organs consist of two or four plume-like gills, placed symmetrically on the sides of the body, in a large branchial cavity, opening forwards on the undert side of the head; in the middle of this opening is placed the siphon or funnel. The sexes are always distinct; but the males are much less numerous than the females, and in many species, at present unknown. They are divided into two orders, the names of which are derived from the number of the branchia.

\section{ORDER I. Dibranchiata, Owen.}

Animal swimming; naked. Head distinct. Eyes sessile, prominent. Mandibles horny (Pl. I., fig. 2). Arms 8 or 10, provided with suckers. Body round or elongated, usually with a pair of fins; branchice two, furmyxine.

* M. Schultze compares the arms of the cephalopods to the oral filaments of

+ According to the established usage, we designate that the under or ventral side of the body, on which the funnel is placed. But if the cuttle fishes are compared with the nucleobranches, or the nautilus with the holostomatous gasteropods, their external analogies seem to favour an opposite conclusion. 
nished with muscular ventricles; ink-gland always present; parietes of the funnel entire.

Shell internal (except in argonauta), horny or shelly, with or without air-chambers.

The typical forms of the cuttle-fishes were well described by Aristotle, and have been repeatedly examined by modern naturalists; yet, until Professor Owen demonstrated the existence of a second order of cephalopods, departing from all the abovementioned characters, it was not clearly understood how inseparably the organisation of the cuttle-fishes was connected with their condition as swimming mollusca, breathing by two gills.

The characters which co-exist with the two gills, are the internal rudimentary shell, and the substitution of other means of escape and defence, than those which an external shell would have afforded ; viz. : powerful arms, furnished with suckers; the secretion of an inky fluid, with which to cloud the water and conceal retreat; more perfect organs of vision; and superadded branchial hearts, which render the circulation more vigorous.*

The suckers (antlia or acetabula), form a single or double series, on the inner surface of the arms. From the margin of each cup, the muscular fibres converge to the centre, where they leave a circular cavity, occupied by a soft caruncle, rising from it like the piston of a syringe, and capable of retraction when the sucker is applied to any surface. So perfect is this mechanism for effecting adhesion, that while the muscular fibres continue retracted, it is easier to tear away the limb than to detach it from its hold. $t$ In the decapods, the base of the piston is surrounded by a horny dentated hoop; which in the uncinated calamaries, is folded, and produced into a long sharp claw.

The ink-bag (fig. 33), is tough and fibrous, with a thin silvery outer coat; it discharges its contents through a duct which opens near the base of the funnel. The ink was formerly used for writing (Cicero), and in the preparation of sepia ; $\ddagger$ and from its indestructible nature, is often found in a fossil state.

* In a few species, which have no fins, the arms are webbed. In the only kind which has an external shell, it is confined to the female sex, and is secreted by the membranes of the arms. It is now quite certain that such shells as those of the fossil ammonites and orthocerata. would be incompatible with dibranchiate organization.

† "The complex, irritable mechanism, of all these suckers, is under the complete control of the animal. Mr. Broderip informs me that he has attempted, with a handnet, to catch an octopus that was floating by, with its long and flexible arms entwined round a fish, which it was tearing with its sharp hawk's bill; it allowed the net to approach within a short distance before it relinquished its prey, when, in an instant, it relaxed its thousand suckers, exploded its inky ammunition, and rapidly retreated under cover of the cloud which it had occasioned, by rapid and vigorous strokes of its circular web." (Owen.)

‡ Indian ink and sepia are now made of lam?-smoke, or of prepared charcoal. 
The skin of the naked cephalopods is remarkable for its variously coloured vesicles, or pigment-cells. In sepia they are black and brown ; in the calamary, Jellow, red, and brown; and in the argonant, and some octopods, there are blue cells besides. These cells alternately contract and expand, by which the colouring matter is condensed or dispersed, or perhaps driven into the deeper part of the skin. The colour accumulates, like a blush, when the skin is irritated, even several hours after separation from the body. During life, these changes are under the control of the animal, and give it the power of changing its hue, like the chameleon. In fresh specimens, the sclerotic plates of the eyes have a pearly lustre; they are sometimes preserved in a fossil state.

The aquiferous pores are situated on the back and sides of the head, on the arms (brachial), or at their bases (buccal pores).

The mantle is usually connected with the back of the head by a broad (" $x u c h a l$ ") muscular band; but its margin is sometimes free all round, and it is supported only by cartilaginous ridges, fitting into corresponding grooves, * and allowing considerable freedom of motion.

The cuttle-fishes are nocturnal, or crepuscular animals, concealing themselves during the day, or retiring to a lower region of the water. They inhabit every zone, and are met with equally near the shore, and in the open sea, hundreds of miles from land. They attain occasionally a much greater size than any other mollusca. MM. Quoy and Gaimard found a dead cuttlefish in the Atlantic, under the equator, which must have weighed 2 cwt. when perfect; it was floating on the surface, and was partly devoured by birds. Banks and Solander, also met with one under similar circumstances, in the Pacific, which was estimated to have measured six feet in length. (Owen.) The arms of the octopods are sometimes two feet long. $t$ From their habits, it is difficult to capture some species alive, but they are frequently obtained, uninjured, from the stomachs of dolphins, and other fishes which prey upon them.

\section{SECTION A. OCTOPODA.}

Arms 8; suckers sessile. Eyes fixed, incapable of rotation. Body united to the head by a broad cervical band. Branchial chamber divided longitudinally by a muscular, partition. Oviduct double; no distinct nidamental gland. Shell external and one-celled (mono-thalamous), or internal and rudimentary.

The Octopods differ from the typical cuttle-fishes in having only eight arms, without the addition of tentacles; their bodies are round, and they sel-

* Termed the " apparatus of resistance," by D'Orbigny.

+ Denys Montfort, having represented a "kraken octopod," in the act of scuttling a three-master, told M. Defrance, that if this were "swallowed," he would in his next edition represent the monster embracing the Straits of Gibraltar, or capsizing a whole squadron of ships. (D'Orbigny.) 
dom have fins. They are the most eccentric or "aberrant" mollusks, superior in organization to all the rest, but manifesting some remarkable and unexpected analogies with the lowest classes of animals.

The males of some species of octopus and eledone, are similar to the females, but are comparatively scarce. Only the females of many others are known, and every specimen of the argonaut hitherto examined (amounting to many hundreds), has been of that sex. Dr. Albert Kölliker has suggested that the real males of the argonaut, and also of octopus gramulatus and tremoctopus violaceus are the hectocotyles, previously mistaken for parasitic voorms.

The hectocotyle of octopus granulatus was described by Cuvier, ${ }^{*}$ who obtained several specimens from octopods eaptured in the Mediterranean. It is five inches in length, and resembles a detached arm of the octopus, its under surface being bordered with 40 or 50 pairs of alternate suckers.

The hectocotyle of tremoctopus was discovered by Dr. Kölliker, at Messina, in 1842, adhering to the interior of the gill-chamber and funnel of the poulpe; it is represented in Pl. I., fig. 3. The body is worm-like, with two rows of suckers on the ventral surface, and an oval appendage at the posterior end. The anterior part of the back is fringed with a double series of branchial filaments (250 on each side). Between the branchiæ are two rows of brown or violet spots, like the pigment cells of the tremoctopus. The suckers (40 on each side) closely resemble those of the tremoctopus, in miniature. Between the suckers are four or five series of pores, the openings of minute canals, passing into the abdominal cavity. The mouth is at the anterior extremity, and is minute and simple; the alimentary canal runs straight through the body, nearly filling it. The heart is in the middle of the back, between the branchiæ; it consists of an auricle and a ventricle, and gives origin to two large vessels. There is also an artery and vein on each side, giving branches to the branchial filaments. A nerve extends along the intestine, and one ganglion has been observed. The oval sac incloses a small but very long convoluted tube, ending in a muscular vas deferens; it contains innumerable spermatozoa.

The hectocotyle of the argonaut was discovered by Chiaje, who considered it a parasitic worm, and described it under the name of trichocephalus acetabularis; it was again described by Costa, $\uparrow$ who regarded it as "a spermatophore of singular shape ;" and lastly by Dr. Kölliker.+ł

It is similar in form to the others, but is only seven lines in length, and has a filiform appendage in front, six lines long. It has two rows of alternate

* An. Sc. Nat. 1 Series, t. 18. p. 147. 1829.

+ An. Sc. Nat. 2 Series, 7. p. 173.

$\ddagger$ Lin. Trans. Vol. 20, pt. 1, p. 9; and in his own zootomical berichte, where it is figured. 
suckers, 45 on each side; but no branchia; the skin contains unmerous changeable spots of red or violet, like that of the argonaut.*

According to the observations of Madame Power, "the newly hatehed argonaut has no shell, and is quite unlike what it afterwards becomes; it is a sort of little worm, having two rows of suckers along its length, with a filiform appendage at one extremity, and a small swelling at the other. It might be supposed to represent an extremely small brachial appendage, from which the other parts were afterwards to be developed." $\dagger$ (Kölliker.)

\section{FAMILY I. ARGONAUTID王.}

Dorsal arms (of the female)- webbed at the extremity, secreting a symmetrical involuted shell. Mantle supported in front by a single ridge on the funnel.

Genus ArgonaUta, Lin. Argonaut or paper sailor.

Etymology, argonautai, sailors of the ship Argo.

Synonyms, ocythoë (Rafinesque). Nautilus (Aristotle and Pliny).

Example, A. hians, Soland, pl. II., fig. 1. China.

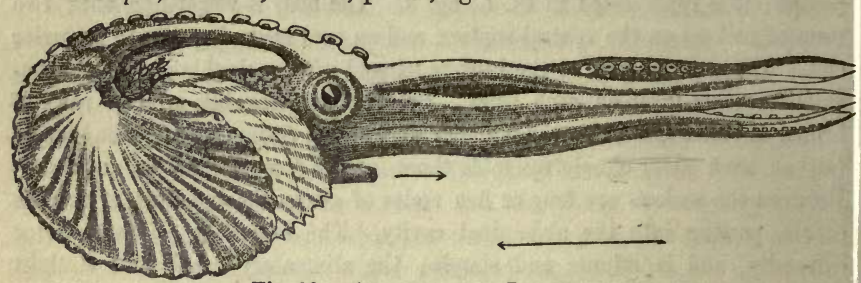

Fig. 32. Argunauta argo L. swimming. $\dagger$

The shell of the argonaut is thin and translucent; it is not moulded on the body of the animal, nor is it attached by shell-muscles; and the unoccupied hollow of the spire serves as a receptacle for the minute clustered eggs. The argonaut sits in its boat with its siphon turned towards the keel, $\S$ and it; sail-shaped (dorsal) arms closely applied to the sides of the shell, as in fig. 32 . where, however, they are represented as partially withdrawn, in order to show the margin of the aperture. It swims only by ejecting water from its fun.

* Similar instances of a permanently rudimentary condition of the male sex, oc cur amongst the lowest organized parasitic crustaceans; the males of achtheres, ler ncoopoda, tracheliaster, \&c., are frequently a thousand times smaller than the female upon whom they live, and from whom they differ both in form and structure. Mr Gosse has described a similar disparity of the sexes in asplanchna.

+ An. Sc. Nat. 2 Series, vol. 16, p. 185.

¥ From a copy of Rang's figure, in Charlesworth's Magazine; one-fourth the na tural size; the small arrow indicates the current from the funnel, the large arrow th direction in which the "sailor" is driven by the recoil.

$\S$ Poli has represented it sitting the opposite way; the writer had once an argonan shell with the nucleus reversed, implying that the animal had turned quite round in it, shell, and remained in that position. The specimen is now in the York Museum. 
nel, and crawls in a reversed position, carrying its shell over its back like a snail. (Madame Power and M. Rang.)

It was the nautilus (primus) of Aristotle, who described it as floating on the surface of the sea, in fine weather, and holding out its sail-shaped arms to the breeze; a pretty fable, which poets have repeated ever since.

Distribution: 4 species of argonaut are known; they inhabit the open sea throughout the warmer parts of the world. Captain King took several from the stomach of a dolphin, caught upwards of 600 leagues from any land.

Fossil : A. hians is found in the sub-apennine tertiaries of Piedmont. This species is still living in the Chinese seas, but not in the Mediterranean.

\section{FAMILY II. OCTOPODID瓜.}

Arms similar, elongated, united at the base by a web. Shell represented hy two short styles, encysted in the substance of the mantle. (Owen.)

Octopus, Cuvier. Poulpe.

Etym., octo, eight, pous ( poda) feet.

Syn., cistopus. (Gray.)

Ex., O. tuberculatus Bl., pl. I., figs. 1 and 2 (mandibles).

Body oval, warty or cirrose, without fins; arms long, unequal; suckers in two rows; mantle supported in front by the branchial septum.

The octopods are the "polypi" of Homer and Aristotle; they are solitary animals, frequenting rocky shores, and are very active and voracious; the females oviposit on sea-weeds, or in the cavities of empty shells. In the markets of Smyrna and Naples, and the bazaars of India, they are regularly exposed for sale. "Although common (at St. Jago) in the pools of water left by the retiring tide, they are not very easily caught. By means of their long arms and suckers they can drag their bodies into very narrow crevices, and when thus fixed it requires great force to remove them. At other times they dart tail first, with the rapidity of an arrow, from one side of the pool to the other, at the same instant discolouring the water with a dark chesnut-brown ink. They also escape detection by varying their tints, according to the nature of the ground over which they pass. In the dark they are slightly phosphorescent." (Darwin.)*

Professor E. Forbes has observed that the octopus, when resting, coils its dorsal arms over its back, and seems to shadow forth the argonaut's shell.

Distr., universally found on the coasts of the temperate and tropical zones ; 46 species are known; when adult they vary in length from 1 inch to 2 feet, according to the species.

Pinnoctopus, D’Orb. Finned octopus.

Body with lateral fins, united behind.

* Journal of a Voyage round the World. The most fascinating volume of travels published since Defoe's fiction. 
The only known species, $P$. cordiformis, was discovered by MM. Quoy and Gaimard, on the coast of New Zealand; it exceeds 3 feet in length.

Eledone. (Aristotle.) Leach.

Type, E. octopodia, I.

Suckers forming a single series on each arm; length 6 to 18 inches. $E$. moschata emits a musky smell.

Distr., 2 sp. Coasts of Norway, Britain, and the Mediterranean.

Cirroteuthis, Eschricht. 1836.

Etym., cirrus, a filament, and teuthis a cuttle-fish.

Body with two transverse fins; arms united by a web, nearly to their tips; suckers in a single row, alternating with cirri. Length 10 inches. Colour violet. The only species (C. Mülleri Esch.) inhabits the coast of Greenland.

\section{Philonexis, D'Orb.}

Etym., philos, an adept in nexis, swimming.

Type, P. atlanticus, D'Orb.

Arms free; suckers in two rows; mantle supported by two ridges on the funnel. Total length, 1 to 3 inches.

Distr., 6 sp. Atlantic and Medit. Gregarious in the open sea; feeding on floating mollusca.

Sub-genus. Tremoctopus (Chiaje), pl. I., fig. 3.

Name from two large aquiferous pores (tremata) on the back of the head. Arms partly, or all webbed half-way up.

Distr., 2 sp. T. quoyanus and violaceus. Atlantic and Medit.

\section{SECTION B. DECAPODA.}

Arms 8. Tentacles 2, elongated, cylindrical, with expanded ends. Suckers pedunculated, armed with a horny ring. Mouth surrounded by a buccal membrane, sometimes lobed and funished with suckers. Fyes moveable in their orbits. Body oblong or elongated, always provided with a pair of fins. Funnel usually furnished with an internal valve. Oviduct single. Nidamental gland largely developed. Shell internal; lodged loosely in the middle of the dorsal aspect of the mantle.

The arms of the decapods are comparatively shorter than those of the octopods; the dorsal pair is usually shortest, the ventral longest. The tentacles originate within the circle of the arms, between the third and fourth pairs; they are usually much longer than the arms, and in cheiroteuthis are six times as long as the animal itself. They are completely retractile into large subocular pouches in sepia, sepiola, and rossia; partly retractile in loligo and sepiotenthis; nor-retractile in cheirotenthis. They serve to seize prey which may be beyond the reach of the ordinary arms, or to moor the animal in safety during the agitation of a stormy sea. 
The shell of the living decapods is either a horny "pen" (gladius) or a calcarious "bone" (sepion); not attached to the animal by muscles, but so loose as to fall out when the cyst which contains it is opened. In the genus spirula, it is a delicate spiral tube, divided into air-chambers by a series of partitions (septa). In the fossil genus spirulirostra, a similar shell forms the apex of a cuttle-bone; in the fossil conoteuthis a chambered shell is combined with a pen; and the belemnite unites all these modifications.

The decapods chiefly frequent the open sea, appearing periodically like fishes, in great shoals, on the coasts and banks. (Owen, D'Orb.)

\section{FAMILY. III. TEUTHID曆. Calamaries, or Seuids.}

Body, elongated; fins short, broad, and mostly terminal.

Shell, (gladius or pen) horny, consisting of three parts,-a shaft, and two lateral expansions or wings.

Sub-family A. Myopside, D'Orb. Eyes covered by the skin.

LoLigo. (Pliny) Lamarck. Calamary.

Syn., teuthis (Aristotle) Gray.

Type, L. vulgaris (sepia loligo L.) Fig. 1. Pl. I., fig. 6 (pen).

Pen, lanceolate, with the shaft produced in front; it is multiplied by age, several being found packed closely, one behind another, in old specimens. (Owen.)

Body tapering behind, much elongated in the males. Fins terminal, united, rhombic. Mantle supported by a cervical ridge, and by two grooves in the base of the funnel. Suckers in two rows, with horny, dentated hoops. Tentacular club with four rows of suckers. Ilength (excluding tentacles) from 3 inches to $2 \frac{1}{2}$ feet.

The calamaries are good swimmers; they also crawl, head-downwards, on their oral disk. The common species is used for bait, by fishermen, on the Cornish coast (Couch). Shells have been found in its stomach, and more rarely sea-weed (Dr. Johnston). Their egg-clusters have been estimated to contain nearly 40,000 eggs (Bohadsch).

Distr., 21 sp. in all seas. Norway-New Zealand.

Sub-genus. Teudopsis, Deslongchamps, 1835.

Etym., teuthis, a calamary and opsis like.

Type, T. Bunellii, Desl.

Pen, like loligo, but dilated and spatulate behind.

Fossil, 5 sp. Upper Lias, France, and Wurtemberg.

Gonatus, Gray.

Animal and pen like loligo in most respects. Arms with 4 series of cups, tentacular club with numerous small cups, and a single large sessile cup armed with a hook; funnel valveless. 
Distr., a single species (G. amana, Moller sp.) is found on the coast o Greenland.

SeProteuthis, Blainville.

Type, S. sepioidea, Bl. Animal like loligo; fins lateral, as long as thi body. Length from 4 inches to 3 feet.

Distr., 13 sp., West Indies, Cape, Red Sea, Java, Australia.

BeLoteuthis, Münster.

Etym., belos, a dart and teuthis.

Type, B. subcostata, Münst. PI. II., fig. 8., U. Lias, Wurtemberg.

Pen, horny, lanceolate; with a very broad shaft, pointed at each end, and small lateral wings.

Distr., 6 sp. described by Münster, considered varieties (differing in agt and sex), by M. D’Orbigny.

Geoteuthis, Münster.

Etym., ge, the earth (i.e. fossil) and teuthis.

Syn., belemnosepia (Agassiz.) belopeltis (Voltz) loligosepia (Quenstedt.)"

Pen broad, pointed behind; shaft broad, truncated in front; lateral wing: shorter than the shaft.

Fossil, 9 sp. U. Lias, Wurtemberg; Calvados; Lyme Regis. Severa undescribed sp. in the Oxf. clay, Chippenham.

Besides the pens of this calamary the ink-bag, the muscular mantle, anc the bases of the arms, are preserved in the Oxford clay. Some of the inkbags found in the Lias are nearly a foot in length, and are invested with brilliant nacreous layer; the ink forms excellent sepia. It is difficult to un derstand how these were preserved, as the recent calamaries "spill their ink" on the slightest alarm. (Buckland).

\section{LePTotecthis, Meyer.}

Etym., Leptos thin, and teuthis.

Type, L. gigas Meyer, Oxford clay, Solenhofen.

Pen very broad and rounded in front, pointed behind; with obscure diverg. ing ribs.

\section{Cranchia, Leach, 1817.}

Named in honour of Mr. J. Cranch, naturalist to the Congo expedition.

Type, C. scabra, Leach.

Body large, ventricose; fins small, terminal; mantle supported in front by a branchial septum. Length 2 inches. Head very small. Eyes fixed. Buccal membrane large, 8-lobed. Arms short, suckers in two rows. Tenta. cular clubs finned behind, cups in 4 rows. Funnel valved.

$P e n$ long and narrow.

* These names must be set aside, being incorrect in themselves, and founded of a total misapprehension of the nature of the fossils. 
Distr., 2 sp. W. Africa. In the open sea.

This genus makes the nearest approach to the octopods.

SeProla. (Rondelet) Leach, 1817.

Ex., S. atlantica (D’Orb.) Pl. I., fig. 4.

Body short, purse-like; mantle supported by a broad cervical band, and a ridge fitting a groove in the funnel. Fins dorsal, rounded, contracted at the base. Suckers in 2 rows, or crowded, on the arms, in 4 rows on the tentacles. Length 2 to 4 inches.

Pen, half as long as the back. S. stenodactyla (sepioloidea, D'Orb.) has no pen.

Distr., 6 sp. Coasts of Norway, Britain, Medit., Maưlitius, Japan, Australia.

Sub-genus. Rossia, Owen (Fidenas? Gray). Mantle supported by a cervical ridge and groove. Suckers in 2 rows on the tentacles. Length 3 to 5 inches.

Distr., 6 sp. Regent Inlet, Britain, Medit., Manilla.

Sub-family B. Oigopsida, D’Orb.

Eyes naked. Fins always terminal, and united, forming a rhomb.

LoLIgopsis, Lam. 1811.

Etym., loligo, and opsis, like.

Type, L. pavo (Lesueur).

Body elongated, mantle supported in front by a branchial septum. Arms short. Cups in 2 rows. Tentacles slender, often mutilated. Funnel valveless.

$P e n$ slender, with a minute conical appendix. Length from 6 to 12 inches. Distr., pelagic. $8 \mathrm{sp.}$ N. Sea, Atlantic, Medit., India, Japan, S. Sea.

Cheiroteuthis, D’Orb.

Etym., cheir, the hand, and teuthis.

Type, C. veranii, Fér.

Mantle supported in front by ridges. Funnel valveless. Vertral arms very long. Tentacles extremely elongated, slender, with distant sessile cups on the peduncles, and 4 rows of pedunculated claws on their expanded ends.

Pen slender, slightly winged at each end. Length of the body 2 inches; to the tips of the arms 8 inches; to the ends of the tentacles 3 feet.

Distr., 2 sp. Atlantic, Medit. On gulf-weed, in the open sea.

\section{Histioteuthis, D’Orb.}

Etym., histion, a veil; and teuthis.

Type, H. bonelliana, Fér. Length 16 inches.

Body short. Fins terminal, rounded. Mantle supported in front by ridges and grooves. Buccal membrane 6-lobed. Arms (except the ventral pair), welbed high up. Tentacles long, outside the web, with 6 rows of dentated cups on their ends. 
Pen short and broad.

Distr., 2 sp. Mediterranean; in the open sea.

ONychoteuthis, Lichtenstein. Uncinated calamary.

Etym., onyx, a claw, and teuthis.

Type, O. banksii, Leach. (= bartlingii ?) Pl. I., fig. 7 and fig. 8 (pen)

Syn., ancistrotenthis (Gray). Onychia (Lesueur).

Pen narrow, with hollow, conical apex.

Arms with 2 rows of suckers. Tentacles long and powerful, armed with a double series of hooks; and usually having a small group of suckers at the base of each club, which they are supposed to unite, and thus use their tentacles in conjunction.* Length 4 inches to 2 feet.

The uncinated calamaries are solitary animals, frequenting the open sea, and especially the banks of gulf-weed (sargasso). O. banksii ranges from Norway to the Cape and Indian ocean; the rest are confined to warm seas. O. dussumieri has been taken swimming in the open sea, 200 leagues north of the Mauritius.

Distr., 6 sp. Atlantic, Indian ocean, Pacific.

Enoploteuthis, D’Orb. Armed calamary.

Etym., enoplos, armed, and teuthis.

Type, E. smithii, Leach.

Syn., ancistrochirus and abralia (Gray), octopodoteuthis (Ruppell), verani (Krohn).

Pen lanceolate. Arms provided with a double series of horny hooks, con cealed by retractile webs. Tentacles long and feeble, with small hooks at th end. Length (excluding the tentacles) from 2 inches to 1 foot; but som species attain a larger size. In the muscum of the College of Surgeons ther is an arm of the specimen of E. unguiculata, found by Banks and Solander in Cook's first voyage (mentioned at p. 64) supposed to have been 6 feet lon when perfect. The natives of the Polynesian Islands, who dive for shell-fish have a well-founded dread of these formidable creatures. (Owen.)

Distr., 10 sp. Medit., Pacific.

Ommastrephes, D'Orb. Sagittated calamary.

Etym., omma, the eyes, and strepho, to turn.

Type, O. sagittatus, Lam.

Body cylindrical; terminal fins large and rhombic. Arms with 2 rows o suckers, and sometimes an internal membranous fringe. Tentacles short an strong, with 4 rows of cups.

Pen, consisting of a shaft with three diverging ribs, and a hollow conica appendix. Length from 1 inch to nearly 4 feet:

* The obstetric forceps of Professor Simpson were suggested by the suckers of th calamary. 
The sagittated calamaries are gregarious, and frequent the open sea in all climates. They are extensively used in the cod-fishery off Newfoundland, and are the principal food of the dolphins and cachalots, as well as of the albatross and larger petrels. The sailors call them "sea-arrows" or "flying squids," from their habit of leaping out of the water, often to such a height as to fall on the decks of vessels. They leave their eggs in long clusters floating at the surface.

Distr., 14 recent sp. ; similar pens ( 4 sp.) have been found fossil in the Oxford clay, Solenhofen; it may, however, be doubted whether they are generically identical.

\section{FAMILY JV. BELEMNITIDA.}

Shell consisting of a pen, terminating posteriorly in a chambered cone, sometimes invested with a fibrous guard. The air-cells of the phragmo-cone are connected by a siphuncle, close to the ventral side.

\section{Belemnites, Lamarck. 1801.}

Etym., belemnon, a dart.*

Ex., B. puzosianus, pl. II., fig. 5.

Phragmocone horny, slightly nacreous, with a minute globular nucleus at its apex; divided internally by numerous concave septa. Pen represented by two nacreous bands on the dorsal side of the phragmocone, and produced beyond its rim, in the form of sword-shaped processes (pl. II., fig. 5). $\dagger$ Guard, fibrous, often elongated and cylindrical; becoming very thin in front, where it invests the phragmocone. $\neq$

Nearly 100 species of belemnites have been found in a fossil state, ranging from the lias to the gault, and distributed over all Europe. The phragmocone of the belemnite, which represents the terminal appendix of the calamaries, is

* The termination ites (from lithos, a stone) was formerly given to all fossil genera.

+ The most perfect specimens known are in the cabinet of Dr. Mantell, and the British Museum; they were obtained by William Buy in the Oxford clay of Christian Malford, Wilts. The last chamber of a lias belemnite in the British Museum is 6 inches long, and $2 \frac{1}{2}$ inches across at the smaller end; a fracture near the siphuncle shows the ink-bag. The phragmocone of a specimen corresponding to this in size, measures $7 \frac{1}{2}$ inches in length.

$\ddagger$ The specific gravity of the guard is identical with that of the shell of the recent jinna, and its structure is the same. Parkinson and others have supposed that it was riginally a light and porous structure, like the cuttle bone; but the mucro of the sepiostaire, with which alone it is homologous, is quite as dense as the belemnite. We ure indebted to Mr. Alex. Williams, M.R.C.S., for the following specific gravities of :ecent and fossil shells, compared with water as 1,000 :-

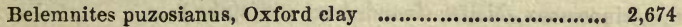

Belemnitella mucronata, chalk ................................. 2,677

Pinna, recent, from the Mediterranean ......................... 2,607

Trichites plottii, from the inferior oolite........................ 2,670

Conus monile, recent .......................................... 2,910

Conus ponderosus, Miocene, Touraine......................... 2,713 
divided into air-chambers, connected by a small tube (siphuncle), like the shel of the pearly nautilus. It is exceedingly delicate, and usually owes its preser tion to the infiltration of calc. spar; specimens frequently occur in the lias with the meniscus-shaped casts of the air-chambers loose, like a pile of watch. glasses. It is usually eccentric, its apex being nearest to the ventral side $a$ the guard. The guard is very variable in its proportions, being sometimes only half an inch longer than the phragmocone, at others one or two feet in length. These variations probably depend to some extent on age and sex M. D'Orbigny believes that the shells of the males are always (comparatively) long and slender; those of the females are at first short, but afterwards grow. ing only at the points, they become as long in proportion as the others. The guard always exhibits (internally) concentric lines of growth; in B. irregulari its apex is hollow. The belemnites have been divided into groups by the presence aud position of furrows in the surface of the guard.

SECTION I. Acœul (Bronn.) without dorsal or ventral grooves.

Sub-section 1. Acuarii, without lateral furrows, but often channelled at the extreme point.

Type., b. acuarius. 20 sp. Lias-Neocomian.

Sub-section 2. Clavati, with lateral furrows.

Type, b. clavatus. $3 \mathrm{sp}$. Lias.

SECTION II. GASTRocceli (D’Orb.) Ventral groove distinct.

Sub-section 1. Canaliculati, no lateral furrows.

Type, b. canaliculatus. 5 sp. Inf. oolite-Gt. oolite.

Sub-section 2. Hastati, lateral furrows distinct.

Type, b. hastatus. $19 \mathrm{sp}$. U. lias-Gault.

SECTION III. NoTocøuI (D'Orb.) with a dorsal groove, and furrowed of each side.

Type, b. dilatatus. $9 \mathrm{sp}$. Neocomian.

The belemnites appear to have been gregarious, from the exceeding abund ance of their remains in many localities, as in some of the marlstone quarrie of the central counties, and the lias cliffs of Dorsetshire. It is also probabl that they lived in a moderate depth of water, and preferred a muddy bottom to rocks or coral-reefs, with which they would be apt to come in perilous col. lision. Belemnites injured in the life-time of the animal have been frequentr noticed.

\section{BelemNitelLA, D'Orb.}

Syn., actinocamax, Miller (founded on a mistake.)

Type, B. mucronata, Sby. Pl. II., fig. 6.

Distr., Europe; N. America. $5 \mathrm{sp.} \mathrm{U.} \mathrm{greensand} \mathrm{and} \mathrm{chalk.}$

The guard of the belemnitella has a straight fissure on the ventral side its alveolar border; its surface exhibits distinct vascular impressions. Th 
phragmocone is never preserved, but casts of the alveolus show that it was chambered, that it had a single dorsal ridge, a ventral process passing into the fissure of the guard, and an apical nucleus.

\section{Acanthoteuthis (Wagner), Münster.}

Etym., acantha, a spine, and teuthis.

Syn., Kelæno (Munster.) Belemnoteuthis?

Type, A. prisea, Ruppell.

Founded on the fossil hooks of a calamary, preserved in the Oxford clay of Solenhofen. These show that the animal had 10, nearly equal arms, all furnished with a double series of horny claws, throughout their length. A pen like that of the ommastrephes has been hypothetically ascribed to these arms, which may, however, have belonged to the belemnite or the belemnoteuthis.

Belemnoteuthis (Miller), Pearce, 1842.

Type, B. antiquus (Cunnington), fig. 33.

Shell consisting of a phragmocone, like that of the belemnite; a horny dorsal pen with obscure lateral bands; and a thin fibrous guard, with two diverging ridges on the dorsal side.

Animal provided with arms and tentacles of nearly equal length, furnished with a double alternating series of horny hooks, from 20 to 40 pairs on each arm; mantle free all round; fins large, medio-dorsal (much larger than in fig. 33).

Fossil in the Oxford clay of Chippenham. Similar horny claws have been found in the lias of Watchett; and a guard equally thin is figured in Buckland's Bridgewater Treatise, t. 44, fig. 14.

In the fossil calamary of Chippenham, the shell is preserved along with the muscular mantle, fins, ink-bag, 'funnel, eyes, and tentacles with their horny hooks; all the specimens were discovered, and developed with unexampled skill, by William Buy, of Sutton, near Chippenham.

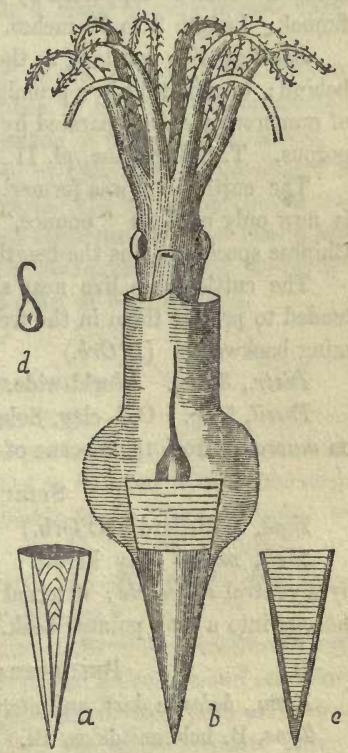

Fig. 33. Belemnoteuthis.*

* Fig. 33. Belemnoteuthis antiquus, $\frac{1}{4}$, ventral side, from a specimen in the cabinet of William Cunnington, Esq., of Devizes. . The last chamber of the phragmocone is preserved in this specimen. $a$, represents the dorsal side of an uncompressed phrag. mocone from the Kelloway rock, in the cabinet of J. G. Lowe, Esq.; c, is an ideal section of the same. Since this woodcut was executed, a more complete specimen has 
Conoteuthis, D’Orb.

Type, C. Dupinianus, D’Orb. Pl. II., fig. 9. Neocomian, France.

Phragmocone slightly curved. Pen elongated, very slender.

This shell, which is like the pen of an ommastrephe, with a chambered cone, connects the ordinary calamaries with the belemnites.

\section{FAMILY V. SEPIADE.}

Shell (cuttle-bone or sepiostaire) calcarious; consisting of a broad laminated plate, terminating behind in a hollow, imperfectly chambered apex (mucro). Animal with elongated tentacles, expanded at their ends.

SEPIA (Pliny), Linnæus.

Type, S. officinalis, L. Pl. I., fig. 5.

Syn., belosepia, Voltz. (B. sepioïdea, pl. II., fig. 3, mucro only.)

Body oblong, with lateral fins as long as itself. Arms with 4 rows of suckers. Mantle supported by tubercles fitting into sockets on the neck and funnel. Length 3 to 28 inches.

Shell as wide and long as the body; very thick in front, concave internally behind; terminating in a prominent mucro. The thickened part is composed of numerous plates, separated by vertical fibres, which render it very light and porous. T. Orbignyana, pl. II., fig. 2.

The cuttle-bone was formerly employed as an antacid by apothecaries; it is now only used as "pounce," or in easting counterfeits. The bone of Chinese species attains the length of $1 \frac{1}{2}$ feet. (Adams.)

The cuttle-fishes live near shore, and the mucro of their shell seems intended to protect them in the frequent collisions they are exposed to in swimming backwards. (D'Orb.)

Distr., $30 \mathrm{sp.}$ World-wide.

Fossil, 5 sp. Oxf. clay, Solenhofen. Several species have been foundei on mucrones from the Eocene of London and Paris. Pl. II., fig. 3.

\section{Sfirulirostra, D’Orb.}

Type, S. Bellardii (D’Orb.) Pl. II., fig. 4. Miocene, Turin.

Shell, mucro only known; chambered internally; chambers connected by a ventral siphuncle; external spathose layer produced beyond the phrag mocone into a long pointed beak.

\section{Beloptera (Blainville) Deshayes.}

Etym., belos, a dart, and pteron, a wing.

Type, B. belemnitoïdes, Bl. Pl. II., fig. 7.

been obtained for the British Museum; the tentacles are not longer than the ordinar arms, owing, perhaps, to their partial retraction; this specimen will be figured in Di Mantell's "Petrifactions and their Teachings." $d$, is a single hook, natural size; th specimens belonging to Mr. Cunnington and the late Mr. C. Pearce, show the larg acetabular bases of the hooks. 
Shell, mucro (only known) chambered and siphuncled; winged externally.

Fossil, 2 sp. Eocene. Paris; Bracklesham

\section{BeLemnosis, Edwards.}

Type, B. anomalns, Sby. sp. Eocene. Highgate (unique.)

Shell, mucro, chambered and siphuncled; without lateral wings or elongated beak.

\section{FAMILY VI. SPIRULIDE.}

Shell entirely nacreous; discoidal ; whirls separate, chambered (polythalamors,) with a ventral siphuncle.

\section{Spirula, Lam., 1801.}

Syn., lituus, Gray.

Ex., S. lævis (Gray.) Pl. I., fig. 9.

Body oblong, with minute terminal fins. MLantle supported by a cervical and 2 ventral ridges and grooves. Arms with 6 rows of very minute cups Tentacles elongated. Funnel valved.

Shell placed vertically in the posterior part of the body, with the involute spire towards the ventral side. The last chamber is not larger in proportion than the rest; its margin is organically connected; it contains the ink-bag.

The delicate shell of the spirula is scattered by thousands on the shores of New Zealand; it abounds on the Atlantic coasts, and a few specimens are yearly brought by the Gulf-stream, and strewed upon the shores of Devon and Cornwall. But the animal is only known by a few fragments, and one perfect specimen, obtained by Mr. Percy Earl on the coast of New Zealand.

Distr., 3 sp. All the warmer seas.

\section{ORDER II. Tetrabranchiata.}

Animal creeping; protected by an external shell.

Head retractile within the mantle. Eyes pedunculated. Mandibles calcarious. Arms very numerous. Body attached to the shell by adductor mus. cles, and by a continuous horny girdle. Branchice four. Funnel formed by the folding of a mnseular lobe.

Shell external, camerated (poly-thalamous) and siphuncled; the inner layers and septa nacreous ; outer layers porcellanous.*

It was long ago remarked by Dillwynn, that shells of the carnivorous gasteropods were almost, or altogether, wanting in the palæozoic and secondary strata; and that the office of these animals appeared to have been performed, in the ancient seas, by an order of cephalopods, now nearly extinct. Above 1,400 fossil species belonging to this order are now known by their shells; whilst their only living representative is the nautilus pompilius,

* The Chinese carve a variety of patterns in the outer opaque layer of the nautilus shell, relieved by the pearly ground beneath. 
of which several specimens have been brought to Europe within the last few years.*

The shell of the tetrabranchiate cephalopods is an extremely elongated cone, and is either straight, or variously folded, or coiled.

It is straight in . . . . . orthoceras . baculites.

bent on itself in . . . . ascoceras . ptychoceras.

curved in . . . . . cyrtoceras . toxoceras.

spiral in . . . . . trochoceras . turrilites.

discoidal in . . . . gyroceras . crioceras.

discoidal and produced in . lituites . . ancyloceras.

involute in ... . . nautilus . . ammonites.

Internally, the shell is divided into cells or chambers, by a series of partitions (septa), connected by a tube or siphuncle. The last chamber is occupied by the animal, the rest are empty during life, but in fossil specimens they are often filled with spar. When the outer shell is removed (as often happens to fossils,) the edges of the septa are seen (as in PI. III., figs. 1, 2.) Sometimes they form curved lines, as in nautilus and orthoceras, or they are zig-zag, as in goniatites (fig. 53,) or foliaceous, as in the ammonite, fig. 34 .

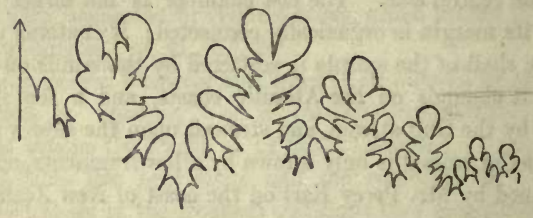

\section{Fig. 34. Suture of an ammonite. $t$}

The outlines of the septa are termed sutures; $;$ when they are folded the elevations are called saddles, and the intervening depressions lobes. In ceratites (fig. 54) the saddles are round, the lobes dentated; in ammonites both lobes and saddles are extremely complicated. Broken fossils show that the septa are nearly flat in the middle, and folded round the edge (like a shirt. frill), where they abut against the outer shell-wall (fig. 37).

The siphuncle of the recent nautilus is a membranous tube, with a very thin nacreous investment; in most of the fossils it consists of a succession of funnel shaped, or bead-like tubes. In some of the oldest fossil genera, actinoceras, gyroceras, and phragmoceras, the siphuncle is large, and contains in

* The frontispiece, copied from Professor Owen's Memoir, represents the animal of the first nautilus, captured off the New Hebrides, and brought to England by Mr. Bennett; it is drawn as if lying in the section of a shell, without concealing any, part of it. The woodcut, fig. 43, is taken from a more perfect specimen, lately acquired by the British Museum, in which the relation of the animal to its shell is accurately shown.

+ A. heterophyllus, Sby., from the lias, Lyme Regis. British Museum. Only one side is represented; the arrow indicates the dorsal saddle.

$\ddagger$ Frota their resemblance to the sutures of the skull, 
its centre a smaller tube, the space between the two being filled up with radiating plates, like the lamellæ of a coral. The position of the siphuncle is very variable; in the ammonitida it is external, or close to the outer margin of the shell (fig. 37). In the nautilidee it is usually central (fig. 35), or internal (fig. 36).

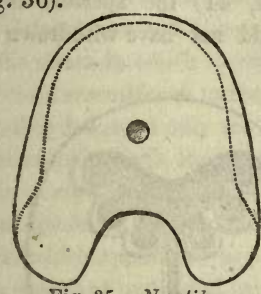

Fig. 35. Nautilus.

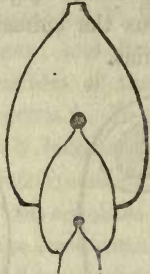

Fig. 36. Clymenia.

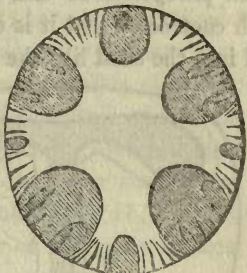

Fig. 37. Hamites.*

The air-chambers of the recent nautilus are lined by a very thin, living membrane; those of the fossil orthocerata retain indications of a thick vascular lining, connected with the animal by spaces between the beads of the siphuncle. $†$

The body-chamber is always very capacious; in the recent nautilus its cavity is twice as large as the whole series of air-cells ; in the goniatite (fig. $39)$, it occupies a whole whirl, and has a considerable lateral extension; and in ammonites communis it occupies more than a whirl.

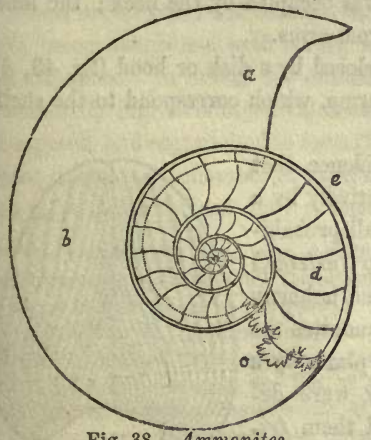

Fig. 38. Ammonites.

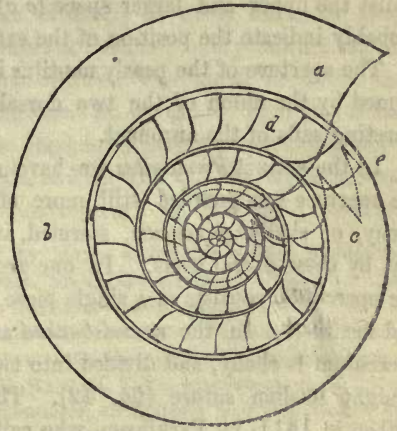

Fig. 39. Goniatites.

* Fig. 35. Nautilus pompilius, L. Fig. 36. Clymenia striata, Münst., see pl. II., fig. 16. Fig. 37. Hamites cylindraceus Defr., see fig. 58.

+ The apocryphal genus spongarium, was founded on detached septa of an orthoceras, from the Upper Ludlow rock, in which the vascular markings distinctly radiate from the siphuncle. Mr. Jones, warden of Clun Hospital, has several of these in apposition.

\pm Fig. 38. Section of ammonites obtusus, Sby. lias, Lyme Regis; from a very young specimen. Fig. 39. Section of goniatites spharicus, Sby. carb. limestone, Bolland (in the cabinet of Mr. Tennant.) The dotted lines indicate the lateral extent of the bodychamber. 
The margin of the aperture is quite simple in the recent nautilus, and affords no clue to the many curious modifications observable in the fossil forms. In the ammonites we frequently find a dorsal process, or lateral projections, developed periodically, or only in the adult (fig. 55, and pl. III., fig. 5).

In phragmoceras and gomphoceras (figs. 40,41 ) the aperture is so much contracted that it is obvious the animal could not have withdrawn its head into the shell like the nautilus.

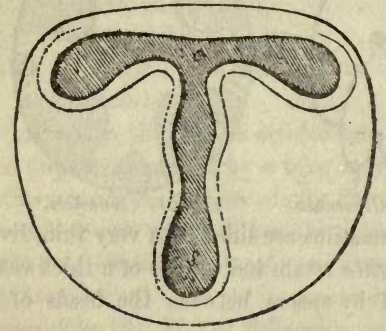

Fig. 40. Gomphoceras.

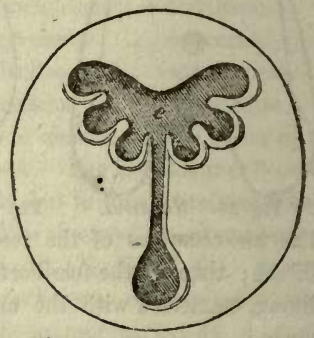

Fig. 41. Phragmoceras:*

M. Barrande, from whose great work on the Silurian Formations of Bohemia these figures are taken, suggests that the lower part of the aperture $(s s)$ which is almost isolated, may have served for the passage of the funnel, whilst the upper and larger space $(c c)$ was occupied by the neck; the lobes probably indicate the position of the external arms.

The aperture of the pearly nautilus is closed by a disk or hood (fig. $43, h$ ), formed by the union of the two dorsal arms, which correspond to the shellsecreting sails of the argonaut.

In the extinct ammonites we have evidence that the aperture was guarded still more effectively by a horny, or shelly operculum, secreted, in all probability, by these dorsal arms. In one group (arietes,) the operculum consists of a single piece, and is horny and flexible.t In the round-backed ammonites the operculum is shelly, and divided into two plates by a straight median suture (fig. 42). They were described in 1811, by Parkinson, who called them trigonellites, and pointed out the resemblance of their

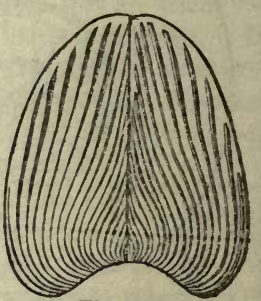

Fig. $42 . \ddagger$

* Fig. 40. Gomphoceras Bohemicum (Barrande), reduced view of the aperture; $s$, the siphonal opening. Fig. 41. phragmoceras callistoma (Barr.) both from the U. Silurian, Bohemia.

+ This form was discovered by the late Miss Mary Anning, the indefatigable colrector of the lias fossils of Lyme Regis, and described by Mr. Strickland, Geol. Journal, vol. I., p. 232. Also by M. Voltz, Mem. de l'Institute, 1837, p. 48.

† Trigonellites lamellosus, Park. Oxford clay, Solenhofen (and Chippenham, ) associated with ammonites lingulatus, Quenstedt. (= A. Brightii, Pratt). From a specimen in the cabinet of Charles Stokes, Esq. 
internal structure to the cancellated tissue of bones. Their external surface is smooth or sculptured; the inner side is marked by lines of growth. Fortyfive kinds are enumerated by Bronn; they occur in all the strata in which ammonites are found, and a single specimen has been figured by M. D'Archiac, from the Devonian rocks of the Eifel, where it was associated with goniatites.*

Calcarious mandibles or rhyncholites (F. Biguet) have been obtained from all the strata in which nautili occur; and from their rarity, their large size and close resemblance to the mandibles of the recent nantilus, it is probable that they belonged only to that genus. $t$ In the Muschelkalk of Bavaria one uautilus ( $N$. arietis, Reinecke, $=\mathrm{N}$. bidorsatus, Schlotheim,) is found, and two kinds of rhyncholite; one sort, corresponding with the upper mandible of the recent nautilus, has been called "rhyncholites hirundo" (pl. II., fig. 11), the other, which appears to be only the lower mandible of the same species, has been described under the name of " conchorhynchus avirostris." $\ddagger$

In studying the fossil tetrabranchiata, it is necessary to take into consideration the varying circumstances under which they have been preserved. In some strata (as the lias of Watchett) the outer layer of the shell has disappeared, whilst the inner nacreous layer is preserved. More frequently only the outer layer remains; and in the chalk formation the whole shell has perished. 'In the calcarious grit of Berkshire and Wiltshire the ammonites have lost their shells ; but perfect casts of the chambers, formed of calcarious spar, remain. $\$$

Fossil orthocerata and ammonites are evidently in many instances dead shells, being overgrown with corals, serpulæ, or oysters ; every cabinet affords such examples. In others the animal has apparently occupied its shell, and prevented the ingress of mud, which has hardened all around it; after this it has decomposed, and contributed to form those phosphates and sulphurets commonly present in the body-chamber of fossil shells, and by which the sediment around them is so often formed into a hard concretion. $\|$ In this state they are

* The trigonellites have been described by Meyer as bivalve shells, under the generic name of aptychus; by Deslongchamps under the name of Munsteria. M. D'Orbigny regards them as cirripedes! M. Deshayes believes them to be gizzards of the ammonites. M. Coquand compares them with teudopsis; an analogy evidently suggested by some of the membranous and elongated forms. such as T. sanguinolarius, found with am. depressus, in the lias of Boll. Ruppell, Voltz, Quenstedt, and Zieten, regard the trigonellites as the opercula of ammonites, an opinion also entertained by many of the most experienced fossil collectors in England.

+ M. D'Orbigny has manufactured two genera of calamaries out of these nautilus beaks! (rhynchoteuthis and palcooteuthis). In the innumerable sections of ammonites which have been made, no traces of the mandibles have ever been discovered.

$\ddagger$ Lepas avirostris (Schlotheim), described by Blainville as the beak of a brachiopod!

$\S$ Called spondylolites by old writers.

II In the alum-shale of Whitby, innumerable concretions are found, which, when struck with the hammer, split open, and disclose an ammonile. See Dr. Mantell's "Thoughts on a Pebble," p. 21. 
permeated by mineral water, which slowly deposits calcarious spar, in crystals, on their walls; or by acidulous water, which remores every trace of the shell, leaving a cavity, which at some future time may again become filled with spar, haring the form of the shell, but not its structure. In some sections of orthocerata, it is evident that the mud has gained access to the aircells, along the course of the blood-ressels; but the chambers are not entirely filled, because their lining membrane has contracted, leaving a space between itself and certain portions of the walls, which correspond in each chamber.

With respect to the purpose of the air-chambers, much ingenuity has been exercised in devising an explanation of their assumed hydrostatic function, whereby the nautilus can rise at will to the surface, or sink, on the approach of storms to the quiet recesses of the deep. Unfortunately for such poetical speculations, the nautilus appears on the surface, only when driven up by storms, and its sphere of action is on the bed of the sea, where it creeps like a snail, or perhaps lies in wait for unwary crabs and shell-fish, like some gigantic "sea-anemone," with outspread tentacles.

The tetrabranchs could undoubtedly swim, by their respiratory jets ; but the discoidal nautili and ammonites are not well calculated, by their forms, for swimming; and the straight-shelled orthocerata and baculites must have held a nearly vertical position, head-downwards, on account of the buoyancy of their shells. The use of the air-chambers, is to render the whole animal (and shell) of nearly the same specific gravity with the water.* The object of the numerous partitions is not so much to sustain the pressure of the water, as to guard against the collisions to which the shell is exposed. They are most complicated in the ammonites, whose general form possesses least strength. $\dagger$ The purpose of the siphuncle (as suggested by Mr. Searles Wood) is to maintain the vitality of the shell, during the long life which these animals certainly enjoyed. Mr. Forbes has suggested that the inner courses of the hamites, broke off, as the outer ones were formed. But this was not the case with the orthocerata, whose long straight shells were particularly exposed to danger; in these the preservation of the shell was provided for by the increased size and strength of the siphuncle, and its increased vascularity. In endoceras we find the siphuncle thickened by internal deposits, until (in some of the very cylindrical species) it forms an almost solid axis.

The nucleus of the shell is rather large in the nautili, and causes an

* A nautilus pompilius (in the cabinet of Mr. Morris) weighs 1lb., aud when the siphuncle is secured, it floats with a $\frac{1}{2} 1 b$ weight in its aperture. The animal would have displaced 2 pints ( $=21 \mathrm{l}$ bs ) of water, and therefore, if it weighed 31bs., the specific gravity of the animal and sbell would scarcely exceed that of salt water.

† The siphuncle and lobed septa did not hold the animal in its shell, as Von B :ch imagined: that was secured by the shell-muscles. The complicated sutures perhaps indicate lobed ovaries; they occur in genera, which must have produced very small eggs. 
opening to remain through the shell, until the umbilicus is filled up with a callous deposit; several fossil species have always a hole through the centre.

In the ammonites, the nucleus is exceedingly small, and the whirls com. pact from the first.

It has been stated that the septa are formed periodically; but it must not be supposed that the shell-muscles ever become detached, or that the animal moves the distance of a chamber all at once. It is most likely that the adductors grow only in front, and that a constant waste takes place behind, so that they are always moring onward, except when a new septum is to be farmed; the septa indicate periodic rests.

The consideration of this fact, that the nautilus must so frequently hare an air-carity between it and its shell, is alone sufficient to convince us, that the chambered cephalopods could not exist in very deep water. They were probably limited to a depth of 20 or 30 fathoms at the utmost.*

It is certain that the sexes were distinct in the tetrabranchiata, but since only the female of the living nautilus is known, we are left to conjecture how ar the differences observable in the shells, are dependant on sex. M. D'Orbigny, having noticed that there are two varieties of almost erery kind of ammonite, -one compressed, the other inflated-naturally assumed that the first were the shells of male individuals ( $\delta$ ), the second of females ( $q)$. Dr. Melrille has made a similar suggestion with respect to the nautili; namely, that the urnbilicated specimens are the males, the imperforated shells, females. This is rendered probable by the circumstance, that all the known specimens of $N$. pompilius were female, and that the supposed male ( $N$. macromphaliss) is very rare, as we have noticed amongst the male dibranchiata. Of the other recent species, both the presumed sexes (N. umbilicatus of and $N$. stenomphalus \&) are comparatively rare.

\section{FAMILY I. NAUTILID.E.}

Shell. Body-chamber capacious. Aperture simple. Sutures simple. Siphuncle central, or internal. (Figs. 35, 36.)

Nautulds, Bresnius, 1732 .

Shell involute or discoidal, few-whirled. Siphancle central.

In the recent nautili, the shell is smooth, but in many fossil species it is corrugated, like the patent iron-roofing, so remarkable for its strength and lightuess. (Buckland.) See pl. II., fig. 10.

* By deep water, naturalists and dredgers seldom mean more than 25 fathoms, a comparatively small depth, only found near coasts and islands. At 100 fathoms the pressure exceeds 265lbs. to the square inch. Empty bottles. securely corked, and sunk with weights bezond 100 fathoms, are always crushed, If filied with liquid, the cork is driven in, and the liquid replaced by salt water; and in drawing the bottle np agrain, the cork is returned to the neck of the bottle, generally in a reversed position. (Sir F. Beaufort.) 


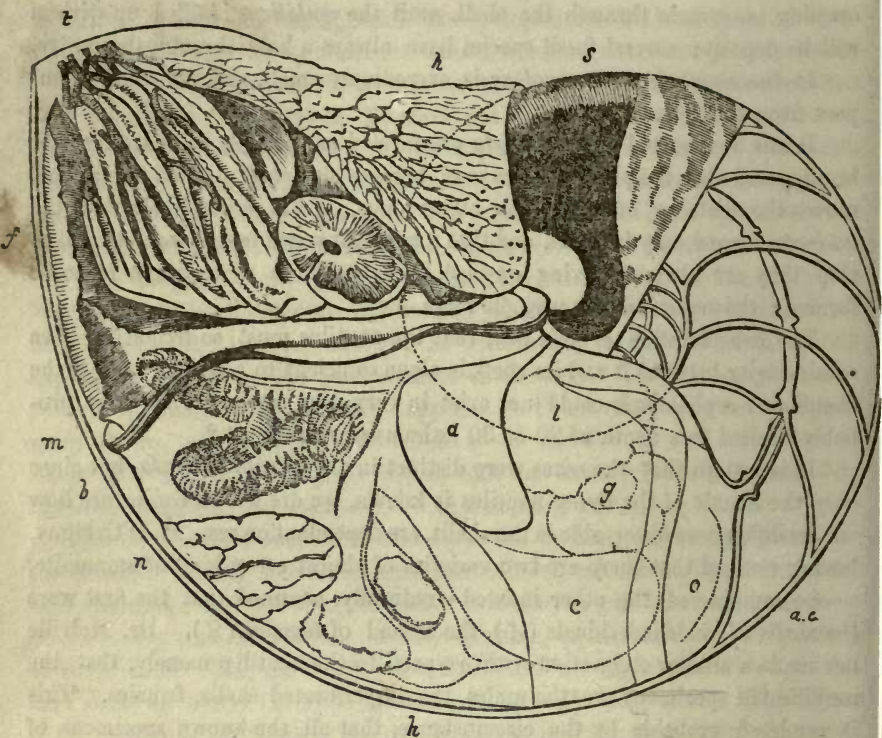

Fig. 43. Nautilus pompilius in its shell.*

The umbilicus is small or obsolete in the typical nautili, and the whirls enlarge rapidly. In the palæozoic species, the whirls increase slowly, and are sometimes scarcely in contact. The last air-cell is frequently shallower in proportion than the rest.

Animal. In the recent nautilus, the mandibles are horny, but calcified to a considerable extent; they are surrounded by a circular fleshy lip, external to which are four groups of labial tentacles, 12 or 13 in each group, they appear to answer to the buccal membrane of the calamary (fig. 1). Beyond these, on each side of the head, is a double series of arms, or brachial tentacles, 36 in number; the dorsal pair are expanded and united to form the hood, which closes the aperture of the shell, except for a small space on each side, which is filled by the second pair of arms. The tentacles are lamellated

* This woodcut and 18 others. illustrating the tetrabranchiata, are the property of Mr. Gray, to whom we are indebted for their use. Fig. 43 represents the recent nautilus, as it appears on the removal of part of the outer shell-wall (from the specimen in the British Museum). The eye is seen in the centre, covered by the hood $(h) ; t$, tentacles, nearly concealed in their sheaths; $f$, funnel; $m$, margin of the mantle, very much contracted; $n$, nidamental gland; $a, c$, air-cells and siphuncle; $s$, portion of the shell; $a$, shell-muscle. The internal organs are indicated by dotted lines; $b$, branchiæ; $h$, heart and renal glands ; $c$, crop ; $g$, gizzard; $l$, liver; o, ovary. 
on their inner surface, and are retractile within sheaths, or "digitations," which correspond to the eight ordinary arms of the cuttle-fishes; their superiority in number bcing indicative of a lower grade of organization. Besides these there are four ocular tentacles, one behind and one in front of each eye; they seem to be instruments of sensation, and resemble the tentacles of doris and aplysia (Owen). On the side of each eye is a hollow plicated process, which is not tentaculiferous. The respiratory funnel is formed by the folding of a very thick muscular lobe, which is prolonged laterally on each side of the head, with its free edge directed backwards, into the branchial cavity; behind the hood it is directed forwards, forming a lobe which lies against the blackstained spire of the shell (fig. $43 \mathrm{~s}$.)* Inside the funnel is a valve-like fold (fig. $44 \mathrm{~s}$ ). The margin of the mantle is entire, and extends as far as the edge of the shell; its substance is firm and muscular, as far back as the line of the shell-muscles and horny girdle, beyond which it is thin and transparent. The shell-muscles are united by a narrow tract, across the hollow occupied by the involute spire of the shell; and are thus rendered horse-shoe shaped. The siphuncle is vascular; it opens into the cavity containing the heart (pericardium), and is most probably filled with fluid from that eavity. (Oven.)

Respecting the habits of the nautilus, very little is known, the specimen dissected by Professor Owen had it crop filled with fragments of a small crab, and its mandibles seem well adapted for breaking shells. The statement that it visits the surface of the sea of its own accord, is at present unconfirmed by observation, although the air cells would doubtless enable the animal to rise by a very small amount of muscular exertion.

Professor Owen gives the following passage, from the old Dutch naturalist, Rumphius, who wrote in 1705, an account of the rarities of Amboina. "When the nautilus floats on the water, he puts out his head and all his tentacles, and spreads them upon the water, with the poop of the shell above water ; but at the bottom he creeps in the reverse position, with his boat above him, and with his head and tentacles upon the ground, making a tolerably quick progress. He keeps himself chiefly upon the ground, creeping also sometimes into the nets of the fishermen; but after a storm, as the weather becomes calm, they are seen in troops, floating on the water, being driven up by the agitation of the waves. This sailing, however, is not of long continuance;

* The funnel is considered the homologue of the foot of the gasteropods, by Loven, a conclusion to which we cannot agree. The cephalopods ought to be compared with the larval gasteropods, in which the foot only serves to support an operculum; -or with the floating tribes in which the foot is obsolete, or serves only to secrete a nidamental raft (ianthina). However, on examining the nautilus preserved in the British Museum, and finding that the funnel was only part of a muscular collar, which extends all round the neck of the animal, we could not avoid noticing its resemblance to the siphonal lappets of paludina, and to that series of lappets (ihcluding the operculigerous lobe) which surrounds the trochus (fig. 87). 
for having taking in all their tentacles, they upset their boat, and so return to the bottom." .

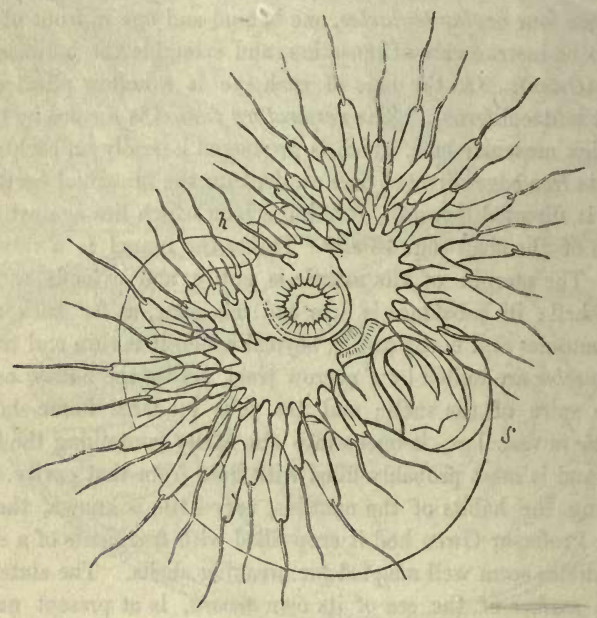

Fig. 44. Nautilus expanded.*

Distr., 2 or $4 \mathrm{sp}$. Chinese seas, Indian ocean, Persian gulf.

Fossil, about $100 \mathrm{sp.}$ In all strata, S. and N. America (Chile). Europe, India (Pondicherry).

Sub-genus. Aturia (Bronn), = Megasiphonia D'Orb.

Type, N. zic-zac Sby. Pl. II., fig. 12, London clay, Highgate.

Shell, sutures, with a deep lateral lobe; siphuncle nearly internal, large, continuous, resembling a succession of funnels.

F'ossil, 4 sp. Eocene, N. America, Europe, India.

Sub-genus? Discites, McCoy. Whirls all exposed; the last chamber sometimes produced. L. silurian.-Carb : limestone.

Temnocheilus, McCoy. Founded on the carinated sp. of the Carb. limestone.

Cryptoceras, D'Orb. Founded on N.dorsalis Phil. and one other species, in which the siphuncle is nearly external.

* Ideal representation of the nautilus, when expanded, by Professor Lovén, who appears to have taken the details from M. Valenciennes memoir in the Archives dre Museum, vol. 2, p. 257. $h$, hood. $s$, siphon. It is just possible, that when the nautilus issues from its shell, the gas contained in the last, incomplete, air-chamber, may expand; but this could not happen under any great pressure of water. 
Liturtes, Breynius.

Etym., liturs, a trumpet.

Syn., Hortolus, Montf. (whirls separate.) Trocholites, Conrad.

Ex., L. convolvans, Schl. L. lituus, Hisinger.

Shell, discoidal; whirls close, or separate; last chamber produced in a straight line; siphuncle central.

Fossil, 15 sp. Silurian, N. America, Europe.

Trochóceras, Barrande, 1848.

Ex., T. trochoides, Bar.

Shell, nautiloid, spiral, depressed.

Fossil, 16 sp. U. Silurian, Bohemia.

Some of the species are nearly flat, and having the last chamber produced would formerly have been considered Lituites.

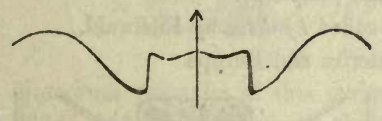

Fig. 45. Clymenia striata, Munst.*

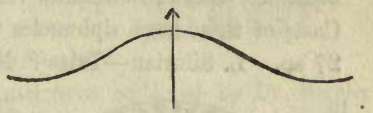

Fig. 46. C. linearis, Munst.

Clymenia, Munster, 1832.

Etym., clymene, a sea-nymph.

Syn. Endosiphonites, Ansted. Sub-clymenia, D'Orb.

Ex., C. striata, pl. II., fig. 16 (Mus. Tennant).

Shell, discoidal; septa simple or slightly lobed; siphuncle internal.

Fossil, 43 sp. Devonian, N. America, Europe.

\section{FAMILY II. ORThoceratide.}

Shell, straight, curved, or discoidal ; body chamber small; aperture contracted, sometimes extremely narrow (figs. 40,41); siphuncle complicated.

It seems probable that the cephalopods of this family were not able to withdraw themselves completely into their shells, like the pearly nautilus; this was certainly the case with some of them, as M. Barrande has stated, for the siphonal aperture is almost isolated from the cephalic opening. The shell appears to have been often less calcified, but connected with more vascular parts than in the nautilus; and the siphuncle often attains an enormous development. In all this, there is nothing to suggest a doubt of their being tetrabranchiate; and the chevron-shaped coloured bands preserved on the orthoceras anguliferus, $\uparrow$ sufficiently prove that the shell was essentially external.

* Fig. 45. Sutures of two species of Clymenia from Phillips' Pal. Fos., Devonshire.

† Figured by D'Archiac and Verneuil, Geol. Trans. 


\section{Orthoceras, Breyn.}

Etym., orthos, straight, and ceras, a horn.

Syn., cycloceras, McCoy. Gonioceras, Hall.*

Ex. O. giganteum (diagram of a longitudinal section), pl. II, fig. 14.

Shell, straight; siphuncle central ; aperture sometimes contracted.

Fossil, 125 typical sp. (D’Orb). $\dagger$ L. Silurian-Trias; N. America, Australia, and Europe.

The orthocerata are the most abundant and wide spread shells of the old rocks, and attained a larger size than any other fossil shell. A fragment of $O$. giganteum, in the collection of Mr. Tate of Alnwick, is a yard long, and 1 foot in diameter, its original length must have been 6 feet. Other species, 2 feet in length, are only 1 inch in diameter, at the aperture.

Sub-genus I. Cameroceras, Conrad (= melia and thoracoceras, Fischer ?). Siphuncle lateral, sometimes very large (simple?).

Casts of these large siphuncles were called hyolites by Eichwald.

27 sp. L. Silurian-Trias? N. America and Europe.

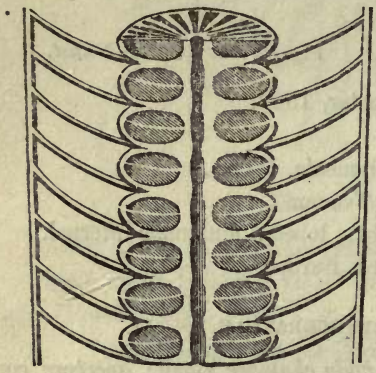

Fig. 47. Actinoceras. $\ddagger$

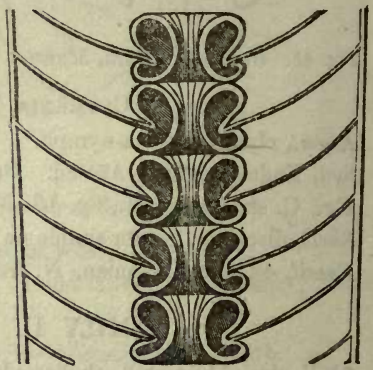

Fig. 48. Ormoceras.

2. Actinoceras (Bronn), Stokes. Siphuncle very large, inflated between the chambers, and connected with a slender central tube by radiating plates. 6 sp. L. Silurian-Carb, N. America, Baltic, and Brit.

3. Ormoceras, Stokes. Siphuncular beads constricted in the middle (making the septa appear as if united to the centre of each). $3 \mathrm{sp}$. L. Silurian, N. America.

4. Huronia, Stokes. Shell extremely thin, membraneous or horny? Siphuncle very large, central, the upper part of each joint inflated, connected

* Theca and Tentaculites are provisionally placed with the Pteropoda, they probably belong here.

† M Barrande has discovered 100 new species in the Upper Silurian rocks of Bohemia.

† Fig. 47. Actinoceras Richardsoni, Stokes. Lake Winipeg (diagram, reduced $\frac{1}{2}$ ). Fig. 48. Ormoceras, Bayfieldi, Stokes. Drummond Island, (from Mr. Stokes' paper, Geol. Trans.) 
with a small central tube by radiating plates. 3 sp. L. Silurian. Drummond Island, Lake Huron.
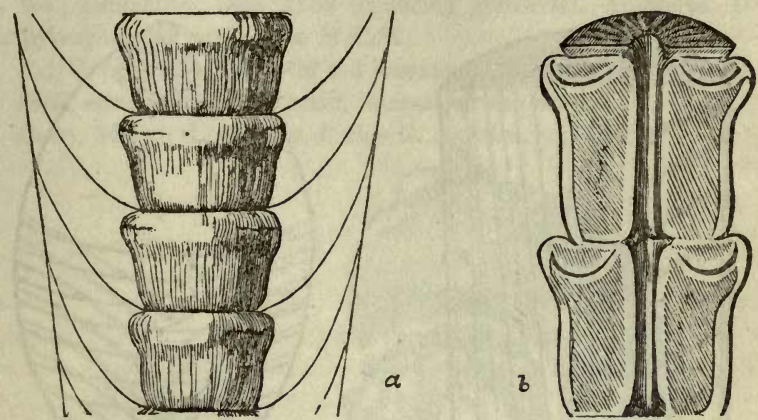

Fig. 49. Huronia vertebralis.*

Numerous examples of this curious fossil were collected by Dr. Bigsby (in 1822), and by the officers of the regiments formerly stationed on Drummond Island. Specimens have also been brought home by the officers of many of the Artic expeditions. But with the exception of one formerly in the possession of Lieut. Gibson, 68., and another in the cabinet of Mr. Stokes, the siphuncle only is preserved, and not a trace remains of septa or shell wall. Some of those seen by Dr. Bigsby in the limestone cliffs, were 6 feet in length.

5. Endoceras, Hall (Cono-tubularia Troost). Shell extremely elongated, drical. Siphuncle very large, cylindrical, lateral; thickened internally by repeated layers of shell, or partitioned off by funnel-shaped diaphragms. $12 \mathrm{sp}$. Lower Silurian, New York.

6. Shell perforated by two distinct siphuncles? O. bisiphonatum Sby, Caradoc sandstone, Brit.

"Orthocerata with two siphuncles have been observed, but there has always appeared something doubtful about them. In the present instance, however, this structure cannot be questioned." (J. Sowerby.)

Small orthocerata of various species, are frequenlly found in the body chamber and open siphuncle of large specimens.t The endoceras gemelliparum and proteiforme of Hall, appear to be examples of this kind.

Gomphoceras, J. Sby, 1839.

Etym., gomphos, a club, and ceras, a horn.

* Fig. 49. Huronia vertebralis, Stokes. $a$, from a specimen in the Brit. M., presented by Dr. Bigsby. The septa are added from Dr. Bigsby's drawing; they were only indicated in the specimen by "colourless lines on the brown limestune," $b$. represents a weathered section, presented to the Brit. Mus. by Captain Kellett and Lieutenant Wood of H.M.S. Pandora. The figures are reduced $\frac{1}{2}$.

t Shells of Bellerophon and M urchisonia are found under the same circumstances. 
Syn., Apioceras (Fischer). Poterioceras (McCoy).

Type, G. pyriforme, Sby., fig. 5I, and G. Bohemicum, Bar. fig. 40.

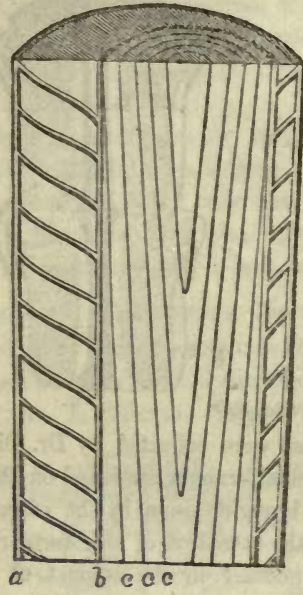

Fig. 50. Endoceras. *

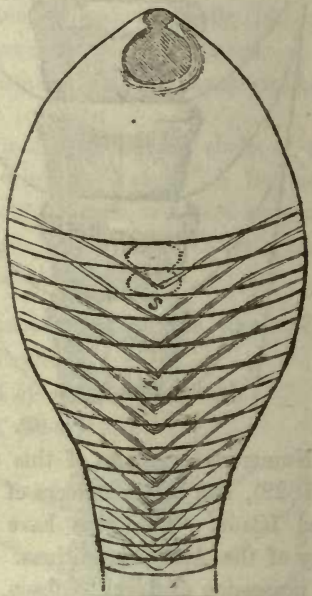

Fig. 51. Gomphoceras.t

Shell, fusiform or globular, with a tapering apex; aperture contracted in the middle; siphuncle moniliform, sub-central.

Distr., 10 sp. Silurian-Carb; N. America, Europe.

\section{ONCOcERAS, Hall.}

Etym., oncos, a protuberance.

$T_{y j p e,}$ O. constrictum, Hall. Trenton limestone.

Shell, like a curved gomphoceras; siphuncle external.

Distr., 3 sp. Silurian, New York.

\section{Phraguóceras, Broderip.}

Etym., phragmos,"a partition, and ceras, a horn.

Type, P. ventricosum (Steininger sp.), pl. II., fig. 15.

Shell curved, laterally compressed; aperture contracted in the middle siphuncle, ventral, radiated. Ex., P. callistoma, Bar., fig. 41.

Distr., 8 sp. U. Silurian-Devonian, Brit., Germany.

= Fig. 50. Diagram of an endoceras (after Hall), $a$, shell-wall. $b$. Wall of siphuncle. cc c. Diaphragms (" embryo-tubes" of Hall).

+ Fig. 51. Gomphoceras pyriforme. L. Ludlow rock, Mochtre hill, Herefordshire (from Murch, silur, syst., reduced $\frac{1}{2}$ ). 3. Beaded siphuncle. 


\section{Crktóceras, Goldf. 1833.}

Etym., curtos, curved, ceras, horn.

Syn., Campulites, Desh. 1832 (including gyroceras). Aploceras, D’Orb. Campyloceras and trigonoceras, McCor.

Ex., C. hybridum, volborthi and beaumonti (Barrande).

Shell, curved ; siphuncle small, internal, or sub-central.

Distr., 36 sp. L. Silurian, Carb-N. America, and Europe.
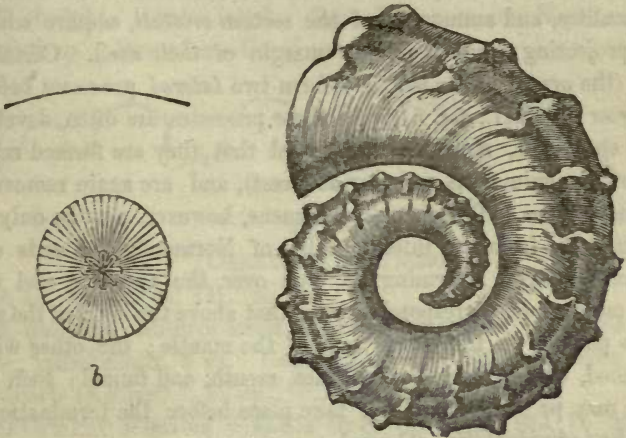

Fig. 52.*

Gró́ceras, Meyer, 1829.

Etym., gyros, a circle, and ceras.

Syn., Nautiloceras, D'Orb.

Ex., G. eifeliense, D'Arch., pl. II., fig. 13. Deronian, Eifel.

Shell, nantiloid; whirls separate; siphnncle excentric, radiated.

Fossil, 17 sp. U. Silurian-Trias? N. America, and Europe.

\section{Ascoceras, Barrande, 1848. $†$}

Etym., ascos, a leather bottle.

Shell, beut upon itself, like ptychoceras.

Distr., 7 sp. U. Silurian, Bohemia.

FAMILY III. AMronitids.

Shell. Body-chamber elongated; aperture guarded by processes, and closed by an operculum; sutures angulated, or lobed and foliated; siphuncle external (dorsal, as regards the shell).

The shell of the ammonitida has essentially the same structure with the nautilus. It consists of an external porcellanonsł layer, formed by the collar

* Fig. 52. Gyroceras goldfussii (= ornatum Goldf). b. Siphuncle of G. depresswm, Goldf. sp. Devonian. Eifel. From M.M. D'Archiac and Verneuil.

+ In Haidinger's Berichte.

I Its microscopic structure has not been satisfactorily examined; Prof. Forbes detected a punctate structure in one species. 
of the mantle only; and of an internal nacreous lining, deposited by the whole extent of its visceral surface. There is an ammonite in the British Museum, evidently broken and repaired during the life of the animal,* which shews that the shell was deposited from within. In some species of ammonites the collar of the mantle forms prominent spines on the shell, which are too deep for the visceral mantle to enter; they are therefore partitioned off (as in $A$. armatus, Lias) from the body whirl and air cells, and not exhibited in casts.

The baculites, and ammonites of the section cristati, acquire when adult a process projecting from the outer margin of their shell. Certain other ammonites (the ornati, coronati, \&c.) form two lateral processes before they cease to grow (pl. III., fig. 5). As these processes are often developed in very small specimens, it has been supposed that they are formed repeatedly in the life of the animal (at each periodic rest), and are again removed when growth recommences. These small specimens, however, may be only dwarfs. In one ammonite, from the inferior oolite of Normandy, the ends of these lateral processes meet, "forming an arch over the apcrture, and dividing it into two outlets, one corresponding with that above the hood of the nautilus, which gives passage to the dorsal fold of the mantle; the other with that below the hood, whence issue the tentacles, mouth, and funnel; such a modification, we may presume, could not take place before the termination of the growth of the individual." $\dagger$ (Owen.)

M. D'Orbigny has figured several examples of deformed ammonites, in which one side of the shell is scarcely developed, and the keel is consequently lateral. Such specimens probably indicate the partial atrophy of the branchia on one side. In the British Museum there are deformed specimens of $\mathrm{Am}$. obtusus, amaltheus, and tuberculatus.
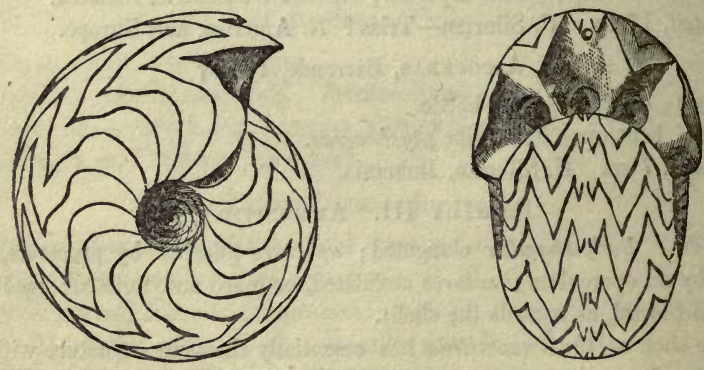

Fig. 53.

* A serpentinus Schloth, U. Lias, Wellingboro. Rev. A. W. Griesbach.

+ This unique and abnormal specimen is in the cabinet of S. P. Pratt, Esq.

I Fig. 53. Goniatites sphericus, Sby. Front and side views of a specimen from the carb limestone of Derbyshire, in the cabinet of Mr. J. 'Tennant; the body-chamber and shell-wall have been removed artificially. 


\section{Goniatites, De Haan.}

Etym., gonia, angles (should be written gonialites?). Syn., aganides, Montf.

Examples, G. Henslowi, pl. III., fig. 1., G. sphericus, fig. 53, and 39. Shell, discoidal; sutures lobed; siphuncle dorsal.

Distr. 150 sp. Devonian-Thias, Europe.

BACTRItes, Sandberger (= stenoceras, D’Orb ?).

Shell, straight; sutures lobed. Type, B. subconicus, Sbger.

Distr., 2 sp. Devonian-Germany.

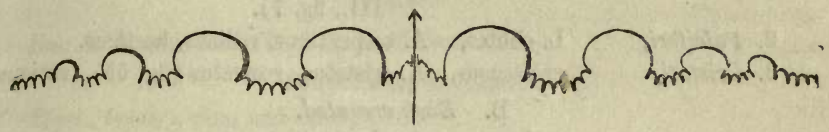

Fig. 54.*

Ceratites, De Haan.

Type, C. nodosus, pl. III., fig. 2.

Shell, discoidal ; sutures lobed, the lobes crenulated. Fig. 54.

Distr., muschelkalk, 8 sp. Germany, Frapce, Russia, Siberia.

Salt-marls (Keuper). 17 sp. S. Cassian, Tyrol.

M. D'Orbigny describes 5 shells from the ganlt and U. greensand as ceratites; but many ammonites have equally simple sutures, when young.

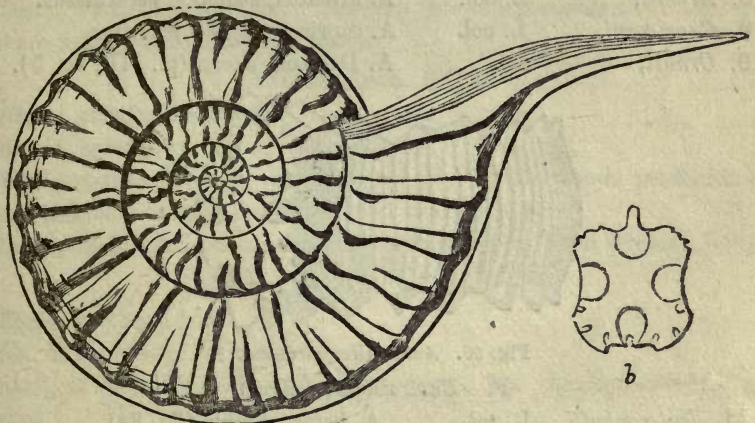

Fig. $55 . \dagger$

AMMonites, Bruguiere.

Etym., ammon, a name of Jupiter, worshipped in Libya nnder the form of a ram. The ammonite is the cornu ammonis of old authors.

* Fig. 54. Suture of ceratites nodosus (Brug). The arrow in the dorsal lobe points towards the aperture.

$\uparrow$ Fig. 55. Ammonites rostratus, Sby. From the U. green-sand of Devizes, in the cabinet of W. Cunnington, Esq. $\quad b$, front view of one of its partitions. 
Syn., orbulites Lam. planulites, Montf.

Shell, discoidal; inner whirls more or less concealed; septa undulated; sutures lobed and foliated; siphuncle dorsal.

Distr., 530 sp. Trias-chalk. Coast of Chili (D’Orb.) Santa Fe de Bogota (Hopkins), New Jersey, Europe, and S. India.

Capt. Alexander Gerard discovered ammonites similar to our L. oolitic species, in the high passes of the Himalaya, 16,200 feet above the sea.

Section A. Back, with an entire keel.

1. Arietes,

L. oolites, A. bifrons (pl. III., fig. 6), bisulcatus (pl. III., fig. 7).

2. Falciferi,

I. oolites, A. serpentinus, radians, hecticus.

3. Cristati, cretaceous, A. cristatus, rostratus (fig. 55), varians. B. Back crenated.

4. Amalthei, ool. A. amalthens, cordatus, excavatus.

5. Rhothomagenses, cret. $\quad$ A. rhothomagensis (pl. III., fig. 4).

C. Back sharp.

6. Disci., oolitic, A. discus, clypeiformis.

D. Back channelled.

7. Dentati, $\begin{cases}\text { cret. } & \text { A. dentatus, lautus. } \\ \text { ool. } & \text { A. Parkinsoni, anguliferus. }\end{cases}$

E. Back squared.
8. Armati,
L. ool.
A. armatus, athletus, perarmatus.
9. Capricorni,
L. ool.
A. capricornus, planicostatus.
10. Ornati,
ool.
A. Duncami, Jason (pl. III., fig. 5).

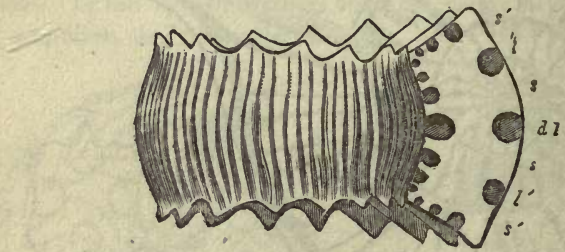

Fig. 56. Ammonites coronatus.*

F. Back round, convex.
11. Heterophylli, L. ool.
A. heterophyllus (fig. 34).
12. Ligati, cret.
A. planulatus (pl. III., fig. 3).
13. Annulati, ool.
A. annulatus, biplex, giganteus.
14. Coronati, ool.
A. coronatus (fig. 56), sublævis.
15. Fimbriati, ool.
A. fimbriatus, lineatus, hircinus.

- Fig. 56. Profile of ammonites coronatus, Brug. (reduced $\frac{1}{2}$ from D'Orbigny) Kelloway rock, France. $d l$. dorsal lobe; $s s$, dorsal saddles; $l^{\prime} l^{\prime}$. lateral lobes; $s^{\prime} s^{\prime}$. lateral saddles; accessory and ventral lobes. The number of accessory lobes increases with age. 
16. Cassiani, $36 \mathrm{sp}$. of very variable form, and remarkable for the number and complexity of their lobes. Trias, Austrian Alps.
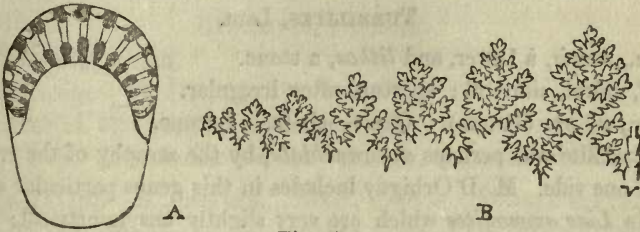

B

Fig. 57.*

Ex., A. Maximiliani (fig. 57), A. Metternichii.

Crioceras, Leveille.

Etym., krios, a ram, and ceras, a horn.

Syn., tropæum, Sby.

Ex., C. cristatum, D’Orb. (pl. III., fig. 8).

Shell, discoidal; whirls separate.

Distr., 9 sp. Neocomian-Gault ; Brit., France.

Toxoceras, D’Orb.

Etym., toxon, a bow, ceras, a horn.

Ex., T. annulare, D'Orb. (pl. III., fig. 12.)

Shell, bow-shaped; like an ammonite uncoiled.

Distr., 19 sp. Neocomian. Between this and crioceras and ancyloceras, there are numerous intermediate forms.

\section{ANCYLOCERAS, D'Orb.}

Etym., anculos, incurved.

Ex. A. spinigerum (pl. III., fig. 10).

Shell, at first discoidal, with separate whirls; afterwards produced at a tangent and bent back again, like a hook or crosier.

Distr., 38 sp. Inf. oolite-chalk. S. America (Chile and Bogota), Europe.

Scaphites, Parkinson.

Etym., scaphe, a boat.

Ex., S. equalis (pl. III., fig. 9).

Shell, at first discoidal, with close whirls; last chamber detached and recurved.

Distr., 17 sp. Neocomian-chalk. Europe.

Helicoceras, D'Orb.

Etym., helix (helicos), a spiral, and ceras, horn.

Ex., H. rotundum, Sby, sp. pl. III., fig. 11 (diagram).

- Fig. 57. Am. Maximiliani Klipstein. (= A. bicarinatus Münst). Trias, Hallstadt (copied from Quenstedt). A, Profile shewing the numerous lobes and saddles. $\mathrm{B}$, suture of one side; $v$, dorsal saddle. 
Shell, spiral, sinistral; whirls separate.

Distr., 11 sp. Inf. oolite?-chalk. Europe.

Turrilites, Lam.

Etym., turris, a tower, and lithos, a stone.

Shell, spiral, sinistral; aperture often irregular.

Distr., 27 sp. (Bronn). Gault-chalk. Europe.

The turrilite was perhaps di-branchiate, by the atrophy of the respiratory organs of one side. M. D'Orbigny includes in this genus particular specimens of certain Lias ammonites which are very slightly unsymmetrical; the same species occur with both sides alike. He also makes a genus (heteroceras) of two turrilites, in which the last chamber is somewhat produced and recurved. T. reflexus (Quenstedt, T. 20, fig. 16) has its apex inflected and concealed.

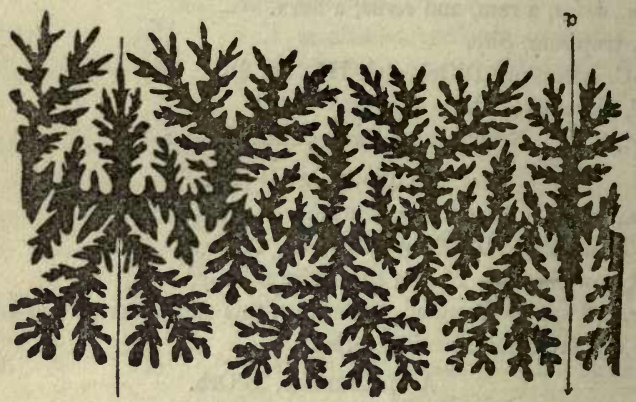

Fig. 58. Sutures of hamites cylindraceus, Defr.*

Hamites, Parkinson.

Etym., hamus, a hook.

$E x$., H. attenuatus, pl. III., fig. 15.

Shell, hook-shaped, or bent upon itself more than once, the courses separate.

Distr., 58 sp. Neocomian-chalk. S. America (Tierra del Fuego)Europe.

The inner courses of this shell probably break away or are "decollated" in the progress of its growth (Forbes). M. D’Orbigny has proposed a new genus, hamulina, for the 20 neocomian species.

Ptychoceras, D’Orb.

Etym., ptyche, a fold.

Ex., P. emericianum, D’Orb., pl. III., fig. 14.

* Fig. 58. Space between two consecutive sutures of the right side, from a specimen in the Brit. Mus, a. dorsal line. b. ventral. Baculite limestone, Fresville. 
Shell, bent once upon itself; the two straight portions in contact.

Distr., 7 sp. Neocomian-chalk. Brit. France.

BAculites, Lamarck.

Etym., baculus, a staff.

Ex., B. anceps. Pl. III., fig. 13.

Shell, straight, elongated; aperture guarded by a dorsal process.

Distr., 11 sp. Neocomian - chalk. Europe, S. America (Chile).

Baculina, D’Orb. B. Rouyana. Neoc., France. Sutures not foliated.

The chalk of Normandy has received the name of baculite limestone, from he abundance of this fossil.

\section{CLASS II. GASTEROPODA.}

The gasteropods, including land-snails, sea-snails, whelks, limpets, and the ke, are the types of the mollusca; that is to say, they present all the leading atures of molluscous organization in the most prominent degree, and make ss approach to the appearance and condition of fishes than the cephalopods, ad less to the crustaceans and zoophytes than the bivalves.

Their ordinary and characteristic mode of locomotion is exemplified by the Immon garden-snail, which creeps by the successive expansion and contraction : its broad muscular foot. These muscular movements may be seen following ch other in rapid waves when a snail is climbing a pane of glass.

The nucleobranches are "aberrant" gasteropods, having the foot thin and rtical; they swim near the surface of the sea, in a reversed position, or there to floating sea-weed.

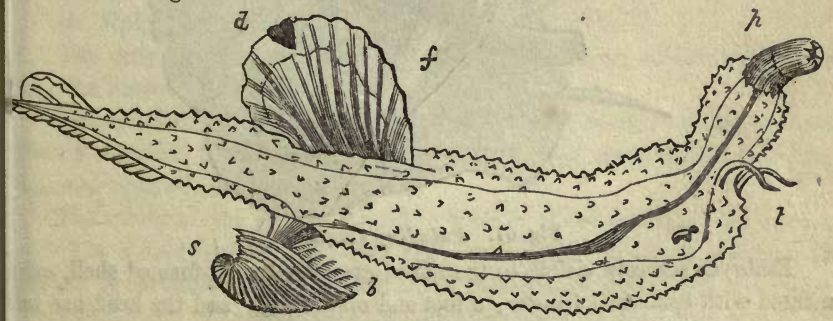

Fig. 59. A nucleobranche.*

The gasteropods are nearly all unsymmetrical, the body being coiled up irally, and the respiratory organs of the left side being usually atrophied. i chiton and dentalium the branchice and reproductive organs are repeated 1 each side.

* Fig. 59. Carinaria cymbium, L. sp. (after Blainville), Mediterranean; p, pro. scis; $t$, tentacles; $b$, branchiæ; $s$, shell ; $f$, foot ; $d$, disk. 
A few species of cymba, litorina, paludina, and helix, are viviparous; the rest are oviparous.

When first hatched the young are always provided with a shell, though in many families it becomes concealed by a fold of the mantle, or it is speedily and wholly lost.*

The gasteropods form two natural groups; one breathing air (pulmonifera), the other water (branchifera). The air-breathers undergo no apparent metamorphosis; when born, they differ from their parents in size only. The water-breathers have at first a small nautiloid shell, capable of concealing them entirely, and closed by an operculum. Instead of creeping, they swim with a pair of ciliated fins springing from the sides of the head; and by this means are often more widely dispersed than we should be led to expect from their adult habits; thus some sedentary species of calyptraa and chiton have a greater range than the "paper-sailor," or the ever-drifting oceanic-snail.

At this stage, which may fairly be compared with the larval condition of insects, there is scarcely any difference between the young of eolis and aplysia, or buccinum and vermetus. (M. Edw.)

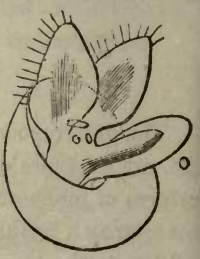

Fig. 60.†

The development of the branchiferous gasteropods may be observed with much facility in the common river-snails (paludina); which are viviparous, and whose oviducts in early summer contain young in all stages of growth some being a quarter of an inch in diameter.

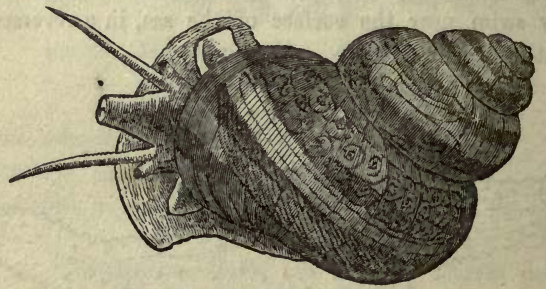

Fig. 61. Paludina viviparu. $\ddagger$

Embryos scarcely visible to the naked eye have a well-formed shell, ornamented with epidermal fringes; a foot and operculum; and the head has long delicate tentacula, and very distinct black eyes.

* M. Lovén believes that the embryo shell of the nudibranches falls off at the time they acquire a locomotive foot.

† Fig. 60. Fry of Eolis (from Alder and Hancock); 0 , the operculum; the origina 8 not larger than the letter 0 .

I Fig. 61. Paludina vivipara $L$. (original); the internal organs are represented a if seen through the shell. The ovary, distended with eggs and embryos, occupies th right side of the body whirl; the gill is seen on the left; and between them the termi nation of the alimentary canal. Surrey Docks, June, 1850. 
The development of the pulmoniferous embryo is best seen in the transparent eggs of the fresh-water limneïds; these are not hatched until the young have passed the larval condition, and their ciliated head-lobes (or veil), are superseded by the creeping disk, or foot.

The shell of the gasteropods is usually spiral, and univalve; more rarely tubular, or conical, and in one genus it is multivalve. The following are its principal modifications :

A. Regularly spiral,

a. elongated or turreted; terebra, turritella.

b. cylindrical; megaspira, pupa.

c. short; buccinum.

d. globular; natica, helix.

e. depressed; solarium.

$f$. discoidal; planorbis.

g. convolute; aperture as long as the shell; cypraca, bulla.

$h$. fusiform; tapering to each end, like fusus.

$i$. trochi-form; conical, with a flat base, like trochus.

$k$. turbinated; conical, with a round base, like turbo.

l. few-whirled; helix hamastoma. Pl. XII., fig. 1.

m. many-whirled; helix polygyrata. Pl. XII., fig. 2.

n. ear-shaped; haliotis.

B. Irregularly spiral ; siliquaria, vermetus.

C. Tubular; dentalium.

D. Shield-shaped; umbrella, parmophorus.

E. Boat-shaped; navicella.

F. Conical or limpet-shaped; patella.

G. Multivalve and imbricated; chiton.

The only symmetrical shells are those of carinaria, atlanta, dentalium, and the limpets.*

Nearly all the spiral shells are dextral, or right.handed; a few are constantly sinistral, like clausilia; reversed varieties of many shells, both dextral and sinistral, have been met with.

The cavity of the shell is a single conical or spiral chamber; no gasteropod has a multilocular shell like the nautilus, but spurious chambers are formed by particular species, such as triton corrugatus (fig. 62), and euomphalus pentangulatus; or under special circumstances, as, when the upper part of the spire is destroyed.

Some spiral shells are complete tubes, with the whirls separate, or scarcely

* The curve of the spiral shells and their opercula, and also of the Nautilus, is $a$ logarithmic spiral; so that to each particular species may be annexed a number, indicating the ratio of the geometrical progression of the dimensions of its whirls. Rev. H. Moseley, "On geometrical forms of turbinated and discoid shells." Phil. Trans. Lond. 1838. Pt. 2, p. 351. 
in contact, as scalaria, cyclostoma, and valvata; but more commonly the inner side of the spiral tube is formed by the pre-existing whirls (fig. 62).

The axis of the shell, around which the whirls are coiled, is sometimes open or hollow; in which case the shell is said to be perforated, or umbilicated (e. g. solarium). The perforation may be a mere chink, or fissure (riam), as in lacuna; or it may be filled ap by a shelly deposit, as in many naticas. In other shells, like the triton, the whirls are closely coiled, leaving only a pillar of shell, or columella, in the centre; such shells are said to be imperforate.

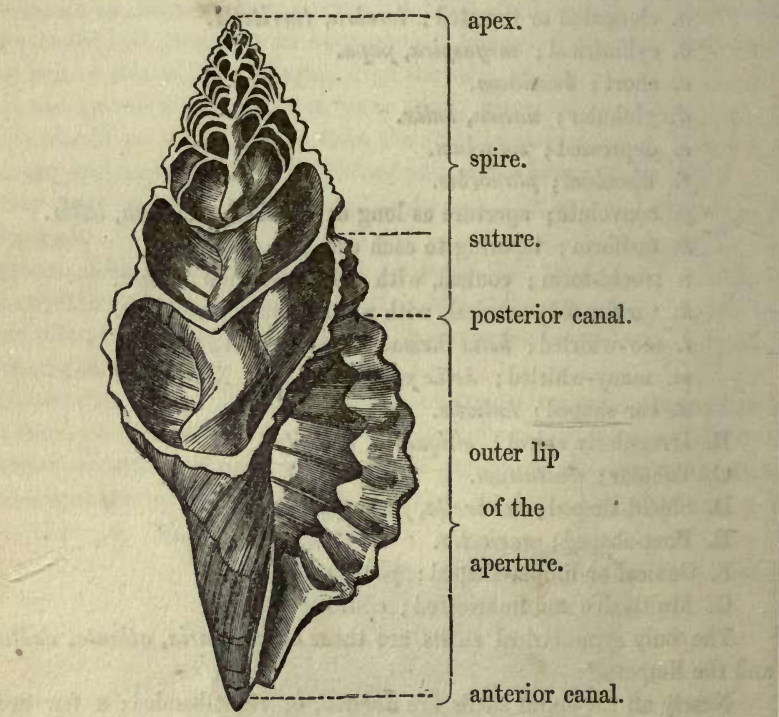

Fig. 62. Section of a spiral univalve.*

The apex of the shell presents important characters, as it was the nucleus or part formed in the egg; it is sinistral in the pyramidellida, oblique and spiral in the nucleobranches and emarginula, and mammillated in turbinella pyrum and fusus antiquus.

The apex is directed backwards in all except some of the patellida, in which it is turned forwards, over the animal's head. In the adult condition of some shells the apex is always truncated (or decollated), as in cylindrella and bulimus decollatus; in others it is only truncated when the animals have lived

- Fig. 62. Longitudinal section of triton corrugatus, Lam., from a specimen in the cabinet of Mr. Gray. The upper part of the spire has been partitioned off many times successively. 
in acidulous waters (e. g. cerithidea and pirena), and specimens may be obtained from more favorable situations with the points perfect. suture.

The line or channel formed by the junction of the whirls is termed the

The last turn of the shell, or body-whirl, is usually very capacious; in the females of some species the whirls enlarge more rapidly than in the males (e. g. buccinum undatum). The "base" of the shell is the opposite end to the apex, and is usually the front of the aperture.

The aperture is entire in most of the vegetable feeders (holostomata), but notched or produced into a canal, in the carnivorous families (siphonostomata); this canal, or siphon, is respiratory in its office, and does not necessarily indicate the nature of the food. Sometimes there is a posterior channel or canal, which is excurrent, or anal, in its function (e. g. strombide and ovulum volva); it is represented by the slit in scissurella, the tube of typhis, the perforation in fissurella, and the series of holes in haliotis.

The margin of the aperture is termed the peristome; sometimes it is continuous (cyclostoma), or becomes continuous in the adult (carocolla); very frequently it is "interrupted," the left side of the aperture being formed only by the body-whirl. The right side of the aperture is formed by the outer lip (labrum), the left side by the inner or columellar lip (labium), or partly by the body-whirl (termed the "wall of the aperture" by Pfeiffer).

The outer lip is usually thin and sharp in immature shells, and in some adults (e. g. helicella and bulimulus); but more frequently it is thickened; or reflected; or curled inwards (inflected), as in cyprea; or expanded as in pteroceras; or fringed with spines as in murex. When these fringes or expansions of the outer lip are formed periodically they are termed varices.

Lines of colour, or sculpture, running from the apex to the aperture are spiral or longitudinal, and others which coincide with the lines of growth are "transverse," as regards the whirls; but stripes of colour extending from the apex across the whirls are often described as "longitudinal" or "radiating," with respect to the entire shell.

Shells which are always concealed by the mantle are colourless, like limax and parmophorus; and those which are covered by the mantle-lobes when the animal expands, acquire a glazed or enamelled surface, like the cowries; when the shell is deeply immersed in the foot of the animal it becomes partly glazed, as in cymba. In all other shells there is an epidermis, although it is sometimes very thin and transparent.

In the interior of the shell the muscular impression is horse-shoe shaped, or divided into two scars; the horns of the crescent are turned towards the head of the animal.

The operculum with which many of the gasteropods close the aperture of their shell, presents modifications of structure which are so characteristic of the sub-genera, as to be worthy of particular notice. It consists of a horny layer, sometimes strengthened by the addition of calcarious matter on its ex- 
terior, and in its mode of growth it presents some resemblance to the sheil itself. Its inner surface is marked by a muscular scar, whose lines bear no relation to the external lines of growth, and its form is unlike the muscular scar in the shell. It is developed in the embyro, within the egg, and the point from which it commences is termed the nucleus; many of the spiral and concentric forms fit the aperture of the shell with accuracy, the others only close the entrance partially, and in many genera, especially those with large apertures (e. g. dolium, cassidaria, harpa, navicella), it is quite rudimentary or obsolete.

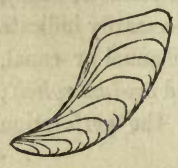

Fig. 63.

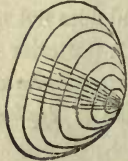

Fig. 64 .

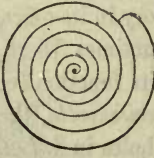

Fig. 65.

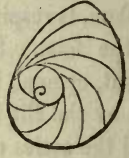

Fig. 66.

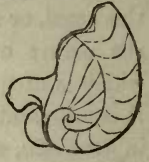

Fig. 67.

The operculum is described as-

Concentric, when it increases equally all round, and the nucleus is central or sub-central, as in paludina and ampullaria (pl. IX., fig. 26).

Imbricated or lamellar (fig. 64), when it grows only on one side, and the nucleus is marginal, as in purpura, phorus, and paludomus.

Claw-shaped, or unguiculate, (fig. 63 , with the nucleus apical or in front), as in turbinellus and fusus; it is claw-shaped and serrated in strombus (fig. 69).

Spiral, when it grows only on one edge, and revolves as it grows; it is always sinistral in dextral shells.

Paucispiral, or few-whirled (fig. 66), as in litorina.

Sub-spiral, or scarcely spiral, in melania. PI. VIII., fig. 25*.

Multispiral or many-whirled (fig. 65) as in trochus, where they sometimes amount to 20 ; the number of turns which the operculum makes is not determined by the number of whirls in the shell, but by the curvature of the opening, and the necessity that the operculum should revolve fast enough to fit it constantly (Moseley).

It is said to be articulated when it has a projection, as in nerita (fig. 67).

Too much importance, however, must not be attached to this very variable plate, as an aid to classification; it is present in some species of voluta, oliva, conus, mitra, and cancellaria, but absent in others; it is (indifferently) horny or shelly in the species of ampullaria and natica; in paludina it is concentric, in paludomus lamellar, in valvata spiral; in solarium and cerithium, it is multispiral or paucispiral.

Some of the gasteropoda can suspend themselves by glutinous threads, 
like litiopa and rissoa parva, which anchor themselves to sea-weeds (Gray), and cerithidea (fig. 68), which frequently leaves its proper element, and is found hanging in the air (Adams). A West India landsnail (cyclostoma suspensum) also suspends itself (Guilding). The origin of these threads has not been explained; but some of the limaces lower themselves to the ground by a thread which is not secreted by any particular gland, but derived from the exudation over the general surface of the body (Lister; D’Orbigny).

The division of this extensive class into orders and families, has engaged the attention of many naturalists, and a variety of methods have been proposed. $\mathrm{Cu}$ vier's classification was the first that possessed much merit, and several of his orders have since been united with advantage.

System of Cuvier.

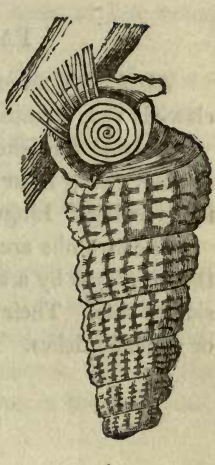

Fig. 68 .

\section{Class. Gasteropoda.}

Order 1. Pectinibranchiata

2. Scutibranchiata

3. Cyclobranchiata

4. Tubulibranchiata

5. Pulmonata

6. Tectibranchiata

7. Inferobranchiata

8. Nudibranchiata

Class. Heteropoda.
System now adopted.

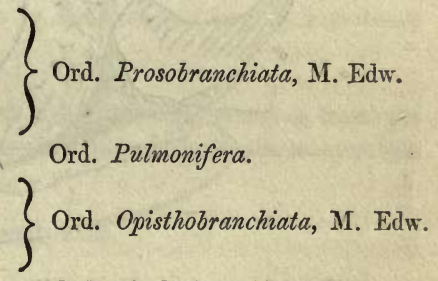

Ord. Nucleobranchiata. BI.

\section{ORDER I. Prósobranchiáta.}

Abdomen well developed, and protected by a shell, into which the whole animal can usually retire. Mantle forming a vaulted chamber over the back of the head, in which are placed the excretory orifices, and in which the branchiæ are almost always lodged. Branchice pectinated, or plume-like, situated (proson) in advance of the heart. Sexes distinct. (M. Edwards.)

\section{SECTION A. Siphonostómata. Carnivorous Gasteropods.}

Shell spiral, usually imperforate; apertare notched or produced into a eanal in front. Operculum horny, lamellar.

Animal provided with a retractile proboscis; eye-pedicels connate with the tentacles; margin of the mantle prolonged into a siphon, by which water is conveyed irito the branchial chamber; gills 1 or 2 , comb-like, placed obliquely over the back. Species all marine. 
FAMILY I. STRómbidz. Wing-shells.

Shell with an expanded lip, deeply notched near the canal. Operculum elaw-shaped, serrated on the outer edge.

Animal furnished with large eyes, placed on thick pedicels; tentacles slender, rising from the middle of the eye-pedicels. Foot narrow, ill adapted for creeping. Lingual teeth single; uncini, three on each side.

The strombs are carrion feeders, and, for molluscous animals, very active; they progress by a sort of leaping movement, turning their heavy shell from side to side. Their eyes are more perfect than those of the other gasteropods, or of many fishes.

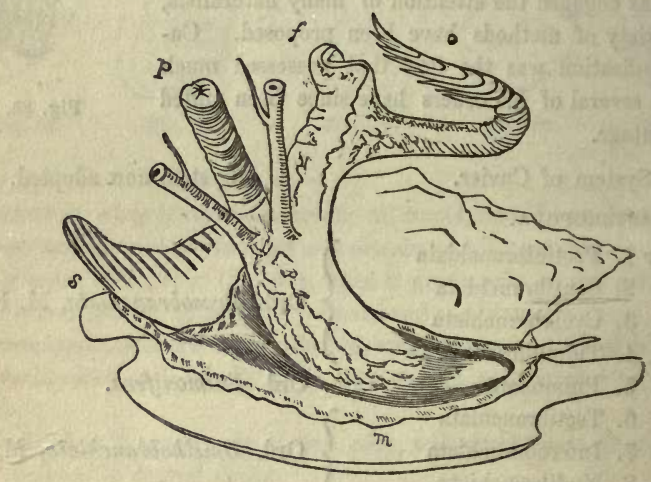

Fig. 69.*

Strombus, L. Stromb.

Etym., strombos, a top.

Type, S. pugilis. Pl. IV., fig. 1.

Shell rather ventricose, tubercular or spiny; spire short; aperture long, with a short canal above, and truncated below; outer lip expanded, lobed above, and sinuated near the notch of the anterior canal. Lingual teeth (S. foridus) 7 cusped; uncini, I tri-dentate, 2, 3 claw-shaped, simple. $\dagger$

Distr., 60 species. West Indies, Mediterranean, Red Sea, India, Man-

* Fig. 69. Strombus auris-Dianæ, L. (after Quoy and Gaimard), Amboina. p, proboscis, between the eye-pedicels ; $f$, foot, folded up; 0 , operculum; $m$, border of the mantle; $s$, respiratory siphon.

+ The lingual dentition of strombus resembles that of aporrhais, and is unlike that of the whelks; but it is more probable that aporrhais is the representative of strombus, than that it is very closely allied. 
ritius, China, New Zealand, Pacific, West America. On reefs, at low water, and ranging to 10 fathoms.

Fossil, 5 cretaceous species ; $3 \mathrm{sp}$. Miocene-. South Europe. There is a group of small shells in the eocene tertiary strata of England and France, nearly related to the living $S$. fissurellus L., some of which have been placed with rostellaria, because the notch in the outer lip is small, or obsolete. They probably constitute a sub-genus, to which Swainson's name strombidia, might be applied. Example, S. Bartonensis. Pl. IV., fig. 2.

The fountain-shell of the West Indies, $S$. gigas, $\mathrm{L}$., is one of the largest living shells, weighing sometimes four or five pounds; its apex and spines are filled up with solid shell as it becomes old. Immense quantities are annually imported from the Bahamas for the manufacture of cameos, and for the porcelain works ; 300,000 were brought to Liverpool aloue in the last year, 1850 (Mr. Archer).

Pteróceras, Lam. Scorpion-shell.

Etym., pteron, a wing, and ceras, a horn.

Type, P. lambis. Pl. IV., fig. 3.

Shell like strombus when young; outer lip, of the adult, produced into several long claws, one of them close to the spire, and forming a posterior canal.

Distr., 10 sp. India, China.

Fossil, nearly $100 \mathrm{sp}$. are enumerated by D'Orbigny, ranging from the lias to the upper chalk; many of them are more nearly related to aporrhais (cerithiada).

\section{Rostellaria, Lam.}

Etym., rostellum, a little beak.

Syn., fusus, Humphreys.

Example, R. curta. Pl. IV., fig. 4.

Shell with an elongated spire; whirls numerous, flat; canals long, the posterior one running up the spire; outer lip more or less expanded, with only one sinus, and that close to the beak.

Distr., 5 sp. Red Sea, India, Borneo, China. Range, 30 fathoms.

Eossil, $70 \mathrm{sp}$. Neocomian - chalk (=aporrhaïs ?). 6 sp. Eocene-. Britain, France, \&c.

The older tertiary species have the outer lip enormously expanded, and smooth-edged; thiy constitute the section hippochrenes of Montfort (e. g. Rost. ampla, Solander. London clay).

Sub-genus? Spinigera, D'Orb. 1847. Shell like rostellaria; whirls keeled; keel developed into a slender spine on the outer lip, and two on each whirl, forming lateral fringes, as in ranella. Fossil, $5 \mathrm{sp}$. Inf. oolitechalk. Britain, Trance. 


\section{Seraphs, Montfort. (Terebellum, Lam.)}

Etym., diminutive of terebra, an anger.

Type, S. terebellum (Linnæus sp.)=T. subulatum, Lam. Pl. IV., fig. 5.

Shell smooth, sub-cylindrical; spire short or none; aperture long and narrow, truncated below; outer lip thin.

Distr., 1 sp. China. Philippines, 8 fms. (Cuming.)

Fossil, 5 sp. Eocene-. London, Paris.

The anifnal of terebellum has an operculum like strombus; its eye-pedicels are simple, without tentacles (Adams). In one fossil species, $T$. fusiforme, there is a short posterior canal, as in rostellaria.

\section{FAMILY II. MURICIDA.}

Shell with a straight anterior canal ; aperture entire behind.

Animal with a broad foot; eyes sessile on the tentacles, or at their base; branchial plumes 2 . Lingual ribbon long, linear; rachis armed with a single series of dentated teeth; uncini, single. Predatory, on other mollusca.

\section{Murex (Pliny) L.}

Types, M. palma-rosæ, Pl. IV., fig. 10. M. tenuispina, Pl. IV., fig. 9. M. haustellum, Pl. IV., fig. 8. M. radix, pinnatus.

Shell ornamented with three or more continuous longitudinal varices; aperture rounded; beak often very long; canal partly closed; operculum concentric, nucleus sub-apical (Pl.IV.,fig.10); lingual dentition (M. erinaceus), teeth single, 3 erested; uncini single, curved.

Distr., $180 \mathrm{sp.}$ World-wide; most abundant on the W. coast of tropical America, in the Chinese Sea, West coast of Africa, West Indies; ranging from low water to 25 fathoms, rarely at 60 fathoms.

\section{Fossil, 160 sp. Eocene-. Britain, France, \&c.}

A few of the species usually referred to this genus, belong to pisania and trophon.

The murices appear to form only one-third of a whirl annually, ending in a varix; some species form intermediate varices of less extent. M. erinaceus a very abundant species on the coasts of the channel, is called "sting-winkle" by fishermen, who say it makes round holes in the other shell-fish with its beak. See p. 27. The ancients obtained their purple dye from species of murex; the small shells were bruised in mortars, the animals of the larger ones taken out. (F. Col.) Heaps of broken shells of the M. trunculus and caldron-shaped holes in the rocks may still be seen on the Tyrian shore. (Wilde.) On the coast of the Morea, there is similar evidence of the employment of $M$. brandaris for the same purpose. (M. Boblaye.)

TYPHIS, Montfort.

Etym., typhos, smoke. 
Type, T. pungens. Pl. IV.. fig. 11.

Shell like murex; but having tubular spines between the varices, of which the last is open, and occupied by the excurrent canal.

Distr., 8 sp. Medit., W. Africa, Cape, India, W. America. -50 fms.

Fossil, 8 sp. Eocene-. London, Paris.

\section{Pisanta, Bivon, 1832.}

Etym., a native of (the coast near) Pisa, in Tuscany.

Syn., Pollia, Enzina, and Euthria (Gray).

Types, P. maculosa. Pl. IV., fig. 14 (Enzina) zonata. Pl. IV., fig. 15.

Shell with numerous indistinct varices, or smooth and spirally striated; canal short; inner lip wrinkled; outer lip crenulated.

Operculum ovate, acute; nucleus apical.

The pisanice have been usually confounded with buccinum, murex, and ricinula.

Distr., about 120 sp. W. Indies, Africa, India, Philippines, S. Seas, W America.

Fossil, ? sp. Eocene-. Bril., France, \&c.

RANFiLA, LaM. Frog-shell.

Syn., Apollon, Montfort and Gray.

Types, R. granifera. Pl. IV., fig. 12. R. spinosa.

Shell with two rows of continuous varices, one on each side.

Operculum ovate, nucleus lateral.

Distr., 50 sp. Medit., Cape, India, China, Australia, Pacific, W. America. Range, low-water to $20 \mathrm{fms}$.

Fossil, 23 sp. Eocene-

\section{Triton. Lam.}

Etym. Triton, a sea-deity. Synn., persona (Montf. Gray).

Type, 'T. tritonis, L. sp. Pl. IV., fig. 13.

Shell with disconnected varices; canal prominent; lips denticulated.

Operculum ovate, sub-concentric.

Distr., 100 sp. W. Indies, Medit., Africa, India, China, Pacific, W. America. Ranging from low-water to 10 or 20 fathoms; one minute species has been dredged at 50 fathoms.

Fossil, 45 sp. Eocene-. Brit., France, \&c. Chile.

The great triton (T. tritonis) is the conch blown by the Australian and Polynesian Islanders. A very similar sp. (T.nodiferus) is found in the Medit., and a third in the W. Indies.

\section{- Fasciolaria, Lam.}

Etym., fasciola, a band.

Type, F. tulipa. Pl. V., fig. 1. 
Shell fusiform, elongated; whirls round or angular; canal open; columellar lip tortuous, with several oblique folds. Operc. claw-shaped. F. gigantea of the $\mathrm{S}$. Seas, attains a length of nearly two feet.

Distr., 16 sp. W. Indies, Medit., W. Africa, India, Australia, S. Pacific, W. America.

Fossil, 28 sp., U. chalk-. France.

Turbinella, Lam.

Etym., diminutive of turbo, a top.

Type, T. pyrum. Pl. V., fig. 2.

Shell thick; spire short ; columella with several transverse folds. Operculum claw-shaped. Fig. 63 . The shank-shell (T. pyrum) is carved by the Cingalese, and reversed varieties of it, from which the priests administer medicine, are held sacred.

Distr., $70 \mathrm{sp.}$ W. Indies, S. America, Africa, Ceylon, Philippines, Pacific, W. America.

Fossil, 20 sp. Miocene-.

Sub-genera. Cynodonta (Schum.) T. cornigera. Pl. V., fig. 3.

Latirus (Montf.) T. gilbula. Pl. V., fig. 4.

Cuma (Humphr.) T. angulifera, inner lip with a single prominent fold operculum like purpura.

Lagena (Schum.) T. Smaragdula, L. sp. N. Australia.

Cancellaria, Lam.

Etym., cancellatus, cross-barred.

Type, C. reticulata. Pl. V., fig. 5.

Shell cancellated; aperture channelled in front: columella with several strong oblique folds; no operculum. The animals are vegetable feeders. (Desh.)*

Distr., 70 sp. W. Indies, Medit., W. Africa, India, China, California.

Fossil, 60 sp. Eocene-. Britain, France, \&c.

Trichotropis, Broderip, 1829.

Etym., Thrix, (trichos) hair, and tropis, keel.

Type, T. borealis, Pl. VI., fig. 8. (= ? Admete, Phil., no operculum.)

Shell thin, umbilicated; spirally furrowed; the ridges with epidermal fringes; columella obliquely truncated; operc. lamellar, nucleus external.

Animal with a short broad head; tentacles distant, with eyes on the middle; proboscis long, retractile.

Lingual dentition similar to strombus; teeth single, hamate, denticulated; uncini $3: 1$ denticulate 2 and 3 simple.

* Cancellaria and trichotropis form a small natural family connected with ceri. thiadce and strombida. 
Distr., 8 sp. Northern seas. U. States, Greenland, Melville Island, Behring's Straits, N. Brit. $15-80 \mathrm{fms}$.

Fossil, 1 sp. Miocene-. Brit.

Pyrula, Lam. Fig-shell.

Etym., diminutive of pyrus, a pear.

Syn., Ficula, Sw. Sycotypus, Br., Cassidula, Humph. Cochlidium, Gray.

Type, P. ficus. (Pl. V., fig. 6.)

Shell pear-shaped ; spire short; outer lip thin; columella smooth : canal long, open. No operculum in the typical species.

Distr., 39 sp. W. Indies, Ceylon, Australia, China, W. America.

Fossil, 30 sp. Neocomian-. Europe, India. Chile.

Pyrula ficus has a broad foot, truncated and horned in front; the mantle forms lobes on the sides, which nearly meet over the back of the shell. Chinese seas, in $17-35$ fms. water. (Adams.)

Sub-genera. Fulgur, Montf. P. perversa. (= Pyrella, Sw. P. spirillus.)

Rapana, Schum. P. bezoar, shell perforated. Operc. lamellar, nucleus external.

Myristica. Sw. P. melongena. Pl. V., fig. 7. Operc. pointed, curved.

Fusus, Lam. Spindle-shell.

Syn., Colus, Humph. Leiotomus, Sw. Strepsidura, Sw.

Type, F. colus. Pl. V., fig. 8.

Shell fusiform; spire many-whirled ; canal straight, long; operculum ovate, curved, nucleus apical. Pl. V., fig. 9*.

Distr., 100 sp. World-wide. The typical sp. are sub_tropical. Australia, New Zealand, China, Senegal, U. States, W. America, Pacific.

Fossil, 320 sp. Bath oolite? Gault-Eocene-. Brit. \&c.

Sub-genera, Trophon, Montf. F. magellanicus, PI. IV., fig. 16. $14 \mathrm{sp.}$ Antarctic and Northern seas. Brit. coast. 5-70 fathoms. Fossit, Chile, Brit.

Clavella, Sw. (cyrtulus, Hinds) body-whirl ventricose, suddenly contracted in front; canal long and straight. Resembling a turbinella, without plaits. 2 sp. Marquesas, Panama. Fossil, Eocene. F. longærus (Solander), Barton, \&c.

Chrysodomus, Sw. F. antiquus (var.) Pl. V., fig. 9. Canal short; apex papillary; lingual dentition like buccinum, $12 \mathrm{sp}$. Spitzbergen, Davis's Straits, Brit., Medit., Kamschatka, Oregon. Low water to $100 \mathrm{fms}$. Fossil, pliocene. Brit., Sicily.

Pusionella, Gray. F. pusio, L. sp. (=F. nifat, Lam.), columella keeled. Operc., nucleus internal, 7 sp. Africa, India. Fossil, tertiary. France.

Fusus colosseus and proboscidalis, Lam., are two of the largest living gasteropods. Fusus (chrysodomus) antiquns, called the red-whelk on the coasts of the channel, and "Buckie" in Scotland, is extensively dredged for 
the markets, being more esteemed than the buccinum. It is the "roaring buckie," in which the sound of the sea may always be heard. In the Zetland cottages it is suspended horizontally, and used for a lamp; the cavity containing the oil, and the canal the wick. (Fleming.) The reversed variety (F. contrarius, Sby) is found in the Medit., and on the coast of Spain; it abounds in the pliocene tertiary (crag) of Essex. The fusus deformis, a similar sp., found off Spitzbergen, is always reversed.

\section{FAMILY III. BucciNIDE.}

Shell notched in front; or with the canal abruptly reflected, producing a kind of varix on the front of the shell.

Animal similar to murex; lingual ribbon long and linear, (fig. 16) rachidian teeth single, transverse, dentated in front; uncini single. Carnivorous.

Buccinum, L. Whelk.

Etym., buccina, a trumpet, or triton's-shell.

Type, B. undatum. Pl. V., fig. 10.

Shell few whirled; whirls ventricose; aperture large; canal very short, reflected; operculum lamellar, nucleus external. (See pisania.)

Distr., 20 typical species. Northern and Antarctic seas. Low water to $100 \mathrm{fms}$. (Forbes). (B ? clathratum, $136 \mathrm{fms}$., off Cape.)

Fossil, 130 sp., including pisania, \&c. Gault ?-Miocene-. Brit., France.

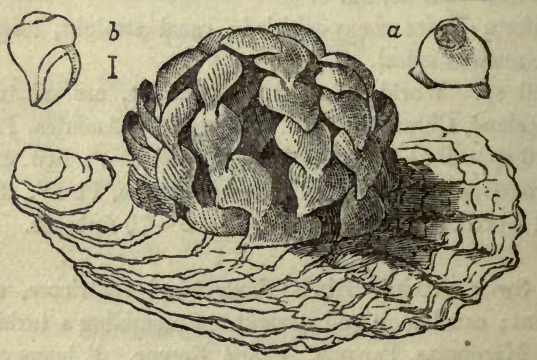

Fig. 70. Nidamental capsu'es of the Whelk.*

The whelk is dredged for the market, or used as, bait by fishermen; it may be taken in baskets, baited with dead fish. Its nidamental capsules are aggregated in roundish masses, which, when thrown ashore, and drifted by the wind resemble corallines. Each capsnle contains fire or six young, which, when hatched, are like fig. $70, b: a$, represents the inner side of a single capsule, shewing the round hole, from which the fry have escaped.

* Fig. 70. From a small specimen, on an oyster-s,ell, in the cabinet of Albany Hancock, Esq. The line at $b$, represents the length of the young shell. 
Sub-genus. Cominella, Gray. Ex. B. limbosum, purpura maculosa, \&c. Operculum as in fusus. About $12 \mathrm{sp.}$

Pseudoliva, Swainson.

Etym., named from its resemblance to oliva, in form.

Syn., sulco-buccinum, D’Orb. Gastridium (Gray), G. Sowerby.

Type, P. plumbea. Pl. V., fig. 12.

Shell globular, thick; with a deep spiral furrow near the front of the body-whirl, forming, as in monoceros, a small tooth on the outer lip; spire short, acute; suture channelled; inner lip callous aperture notched in front; operculum? Animal unknown.

Distr., 6 sp.? W. America.

Fossil, 5 sp. Eocene. Brit., France, Chile.

? Arolax (Roissy), Conrad. Lea.

Etym., an aulax, wịthout furrow.

Syn., buccinanops, D’Orb. Leiodomus, Sw. Bullia, Gray.

Types, A. gigantea, Lea. Buc. lævigatum. B. semiplicata, Pl. V., fig. 14.

Shell variable; like buccinum, pseudoliva, or terebra; sutures enamelled; inner lip callous.

Animal without eyes; foot very broad; tentacles long and slender; operculum pointed, nucleus apical.

Distr., 26 sp. Brazil, W. Africa, Ceylon, Pacific, W. America.

Fossil, 3 sp. Eocene-. N. America, France.

\section{? HaLIa, Risso.}

Etym., halios, marine. Syn., priamus, Beck.

Types, bulla helicoides (Brocchi). Miocene, Italy. Helix priamus Meuschen). Coast of Guinea?

Shell like achatina; ventricose, smooth; apex regular, obtuse; operc. ? The fossil species occurs with marine shells, and sometimes coated by a coral (lepralia).

Terebra, Lamarck. Anger-shell.

Syn., acus, Humph. Subula, Bl. Dorsanum, Gray.

Type, T. maculata. Pl. V., fig. 13.

Shell long, pointed, many-whirled; aperture small; canal short; operc. pointed, nuclens apical.

Animal blind, or with eyes near the summit of minnte tentacles.

Distr., 109 sp., mostly tropical. Medit. (1 sp.) India, China, W. America.

Fossil, 24 sp. Eocene-. Brit., France, Chile.

Eburna, Lamarck. Ivory-shell.

Etym., ebur, ivory. Syn., latrunculus, Gray. 
Type, E. spirata. Pl. V., fig. 11.

Shell umbilicated when young; inner lip callous, spreading and covering the umbilicus of the adult; operculum pointed, nucleus apical.

Distr., 9 sp. Red Sea, India, Cape, Japan, China, Australia. Solid, smooth shells, which have usually lost their epidermis, and are pure white, spotted with dark red; the arimal is spotted like the shell. 14 fms. (Adams.)

\section{Nassa, Lam. Dog-whelk.}

Etym., nassa, a basket used for catching fish.

Syn., desmoulinsia and northia, Gray.

Type, N. arcularia. Pl. V., fig: 15.

Shell like buccinum; columellar lip callous, expanded, forming a toothlike projection near the anterior canal. Operc. ovate, nucleus apical. Lingual teeth arched, pectinated; uncini, with a basal tooth.

The animal has a broad foot, with diverging horns in front, and two little tails behind. N. obsoleta (Say) lives within the influence of fresh water and becomes eroded. $N$. reticulata, $L$, is common on the English shores, at low-water, and is called the dog-whelk by fishermen.

Distr., 68 sp. Low-water-50 fms. World-wide. Arctic, Tropical and Antarctic Seas.

Fossil, 19 sp. Eocene-. Brit., \&c., N. America.

Sub-genus, cyllene, Gray. C. Oweni, Pl. V., fig. 17. Outer lip with a slight sinus near the canal; sutures channelled. W. Africa, Sooloo Islands, Borneo. Fossil, Miocene, Touraine.

Cyclonassa, Swainson. C. neritea, Pl. V., fig. 16.

Phos, Montfort.

Etym., phos, light. Syn., rhinodomus, Sw.

Type, P. senticosus, Pl. V., fig. 18.

Shell like nassa ; cancellated; outer lip striated internally, with a slight sinus near the canal; columella obliquely grooved.

The animal has slender tentacles, with the eyes near their tips.

Distr., 30 sp. (Cuming.) Red Sea, Ceylon, Philippines, Australia, W. America.

\section{P Ringicula, Deshayes.}

Etym., diminutive of ringens, from ringo, to grin.

Type, R. ringens, Pl. V., fig. 21.

Shell minute, ventricose, with a small spire; aperture notched, columella callous, deeply plaited; outer lip thickened and reflected.

Distr., 4 sp.? Medit., India, Philippines, Gallapagos.

Fossil, 9 sp., Miocene-. Brit., France. Ringicula is placed with nassa 
by Mr. Gray, and Mr. S. Wood; it appears to us very nearly allied to cinulia (=avellana, D'Orb.) in tornatellida.

\section{Purpura (Adans), Lam. Purple.}

Type, P. persica, Pl. VI., fig. 1.

Shell striated, imbricated or tuberculated; spire short; aperture large, slightly notched in front; inner lip much worn and flattened. Operc. lamellar, nucleus external. Pl. VI., fig. 2. Lingual dentition like murex erinaceus; teeth transverse, 3 crested; uncini small, simple.

Many of the purpura produce a fluid which gives a dull crimson dye; it may be obtained by pressing on the operculum. P. lapillus abounds on the British coast at low-water, amongst sea-weed; it is very destructive to mussel-beds (Fleming).

Distr., 140 sp. W. Indies, Brit., Africa, India, New Zealand, Pacific, Chile, California, Kamschatka. From low-water-25 fathoms.

Fossil, 30 sp. Miocene- Brit., France, \&c.

Sub-genus. Concholepas, Favan. C: lepas (Gmelin sp.) Pl. VI., fig. 3. Peru. The only sp. differs from purpura in the size of its aperture, and smallness of the spire.

\section{? Purpurina (Lycett, 1847). D'Orb.}

Shell, ventricose, coronated; spire, short; aperture, large, scarcely notched in front.

Fossil, 9 sp., Bath-oolite. Brit. France. The type, P. rugosa, somewhat resembles purpura chocolatum (Duclos), but the genus probably belongs to an extinct group.

\section{Monoceros, Lam.}

Etym., monos, one; ceras, horn.

Syn., acanthina, Fischer. Chorus, Gray.

Type, M. imbricatum. Pl. VI., fig. 4 (Buc. monoceros, Chemn).

Shell, like purpura ; with a spiral groove on the whirls, ending in a prominent spine on the outer lip. This genus is retained on account of its geographical curiosity ; it consists of sp. of purpura, lagena, turbinella, pseudoliva, \&c.

Distr., 18 sp. W. coast of America.

Fossil, tertiary. Chile.

M. gigantens (chorus) has the canal produced like fusus. M. cingulatum is a turbinella, and several sp. belong more properly to lagena.

Pedicularia, Swainson.

Type, P. sicula. PI. VI., fig. 5 (thyreus, Phil.).

Shell very small, limpet-like; with a large aperture, channelled in front, and a minute, lateral spire. Lingual dentition peculiar; teeth single, hooked, denticulated; uncini, $3 ; 1$, four-cusped, 2,3 , elongated, three-spined. 
Distr., 1 sp. Sicily, adhering to corals. Closely allied to purpura madreporarum, Sby. Chinese Sea.

Ricinula, Iam.

Etym., dimunitive of ricinus, the (fruit of the) castor-oil plant.

$E x$., R, arachnoïdes. Pl. VI., fig. 9 (=murex ricinus L.).

Shell, thick, tuberculated, or spiny ; aperture contracted by callous projections on the lips. Operc. as in purpura.

Distr. 25 sp. India, China, Philippines, Australia, Pacific.

Fossil, 3 sp. Miocene-. France.

\section{Planaxis, Lam.}

Type, P. sulcata. Pl. VI., fig. 6. Syn., quoyia and leucostoma.

Shell, turbinated; aperture notched in front; inner lip callous, channelled behind; operculum subspiral (quoyia) or semi-ovate. PI. VI., fig. 7.

Distr., 11 sp. W. Indies, Red Sea, Bourbon, India, Pacific, and Peru.

Fossil, miocene? them.

Small coast shells, resembling periwinkles, with which Lamarck placed

Magilus, Montf., 1810.

Syn., campulote, Guettard, 1759. Leptoconchus, Rüppell.

Type, M. antiquus. Pl. V., figs. 19, 20.

Shell, when young, spiral, thin; aperture channelled in front; adult, prolonged into an irregular tube, solid behind; operculum lamellar.

Distr., 1 sp.? Red Sea. Mauritius.

The magilus lives fixed amongst corals, and grows upwards with the growth of the zoophytes in which it becomes immersed; it fills the cavity of its tube with solid shell, as it advances.

\section{CAssis, Lam. Helmet-shell.}

Syn., bezoardica, Schum. Levenia, Gray. Cypræcassis, Stutch.

Type, C. flammea. Pl. VI., fig. 14.

Shell, ventricose, with irregular varices; spire, short; aperture long, outer lip reflected, denticulated; inner lip spread over the body-whirl; canal sharply recurved. Operculum small, elongated; nucleus in the middle of the straight inner edge.

Distr., 34 sp. Tropical seas; in shallow water. W. Indies, Medit., Africa, China, Japan, Australia, New Zealand, Pacific, Mexico.

Fossil, 36 sp. Eocene-. Chile, France.

The queen-conch (C. madagascariensis) and other large species, are used in the manufacture of shell cameos, p. 46. The periodic mouths (varices, which are very prominent, are not absorbed internally as the animal grows.

Oniscia, Sowerby.

Etym., oniscus, a wood louse. Syn., morum, Bolten. 
Type, O. oniscus; O. cancellata, pl. VI., fig. 15.

Shell, with a short spire, and a long narrow aperture, slightly truncated in front; outer lip thickened, denticulated; inner lip granulated.

Distr., 6 sp. W. Indies, China, Gallapagos. (20 fms.)

Fossil, 3 sp. Miocene.

Cithara, Schumacher.

Etym., cithara, a guitar. Syn., mangelia, Reeve (not Leach).

Type, cancellaria citharella, Lam. (eithara striata, Schum.)

Shell, fusiform, polished, ornamented with regular longitudinal ribs; aperture linear, truncated in front, slightly notched behind ; outer lip margined, denticulated within; inner lip finely striated. Operc.

Distr., above 50 sp. of this pretty little genus were discovered by Mr. Cuming, in the Philippine Islands.

\section{Cassidaria, Lam.}

Etym., cassida, a helmet.

Syn., morio, Montf. Sconsia, Gray.

Type, C. echinophora. Pl. VI., fig. 13.

Shell, ventricose; canal produced, rather bent. No operculum.

Distr., 5 sp. Medit.

Fossil, 10 sp. Eocene-. Brit., France, \&c.

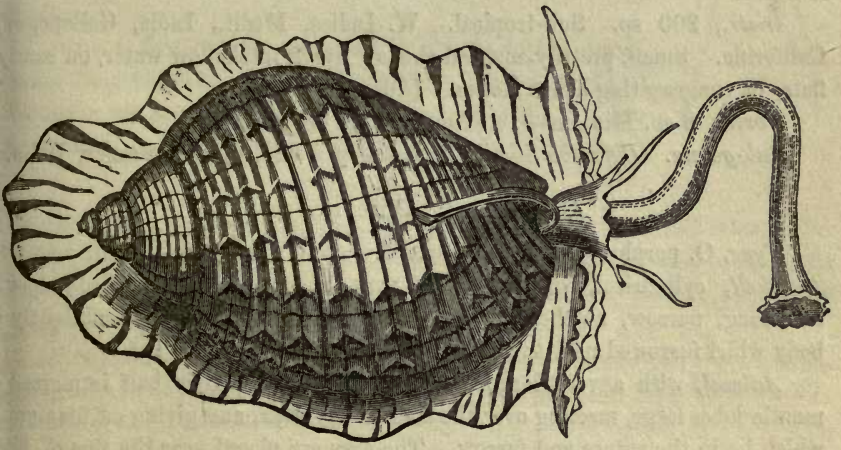

Fig. 71.*

DoLIux, Lam. The tun.

Type, D. galea. Pl. VI., fig. 12.

Shell, ventricose, spirally furrowed; spire small; aperture very large; outer lip crenated. No operc.

Distr., 14 sp. Medit., Ceylon, China, Australia, Pacific.

* D. perdix, L. sp. $\frac{1}{3}$ nat. size (after Quoy). Vanicoro, Pacific. The proboscis is exserted, and the siphon recurved over the front of the shell. 
Fossil, 7 sp. (?Chalk. Brit.) Miocene-. S. Europe.

Sub-genus, malea, Valenc. (D. personatum) outer lip thickened and denticulated; inner lip with callous prominences.

HARPA, Lam. Harp-shell.

Type, H. ventricosa. Pl. VI., fig. 11. (=Buc. harpa, L.)

Shell, ventricose; with numerous ribs, at regular intervals; spire small; aperture large, notched in front. No operc.

The animal has a very large foot, with the front crescent-shaped, and divided by deep lateral fissures from the posterior part, which is said to separate spontaneously when the animal is irritated. Mostly obtained from deepwater, and soft bottoms.

Distr., 9 sp. Mauritius, Ceylon, Philippines, Pacific.

Fossil, 4 sp. Eocene-. France.

\section{Columbella, Lam.}

Etym., diminutive of columba, a dove.

Type, C. mercatoria. Pl. VI., fig. 10.

Shell, small; with a long narrow aperture; outer lip thickened (especi. ally in the middle), dentated; inner lip crenulated. Operculum very small lamellar.

Distr., 200 sp. Sub-tropical. W. Indies, Medit., India, Gallapagos California. Small, prettily-marked shells ; living in shallow water, on sandy flats, or congregating about stones. (Adams.)

Fossil, 8 sp. Miocene-. (The Brit. sp. are pisania).

Sub-genus. Columbellina, D’Orb. $4 \mathrm{sp}$. Cretaceous. France, India.

OLrva, Lam. Olive, rice-shell.

Type, O. porphyria. Pl. VI., fig. 16. Syn., strephona, Brown.

Shell, cylindrical, polished; spire very short, suture channelled; aper. ture long, narrow, notched in front; columella callous, striated obliquely body whirl furrowed near the base. No operc. in the typical sp.

Animal, with a very large foot, in which the shell is half immersed, mantle lobes large, meeting over the back of the shell, and giving off filament: which lie in the suture and furrow. The eyes are placed near the tips of th tentacles.

The olives are very active animals, and can turn over, when laid on thei back; near low water they may be seen gliding about or burying in the sand: as the tide retires; they may be taken with animal baits, attached to line They range downwards to 25 fms.

Distr., 117 sp. Sub-tropical, W. and E. America. W. Africa, Indie, China, Pacific.

Fossil, 20 sp. Eocene-. Brit., France, \&c. 
Sub.genera. Olivella, Sw. O. jaspidea, pl. VI., fig. 19.

Animal with small, acute frontal lobes. Operc. nucleus sub-apical.

Scaphula, Sw. O utriculus, pl. VI., fig. 18.

Frontal lobes large, rounded, operculate.

Agaronia, Gray. O. hiatula, pl. VI., fig. 17.

No eyes or tentacles. Frontal lobes moderate, acute.

Ancillaria, Lam.

Etym., ancilla, a maiden.

Types, A. subulata, pl. VI., fig. 20. A. glabrata, pl. VI. fig. 21.

Shell like oliva; spire produced, and entirely covered with shining enamel. Operc. minute, thin, pointed. Lingual teeth pectinated. Uncini simple, hooked.

Animal like oliva ; said to use its mantle-lobes for swimming. (D'Orb.) In A. glabrata, a space resembling an umbilicus, is left between the callous inner lip and the body whirl.

Distr., 23 sp. Red Sea, India, Madagascar, Australia, Pacific.

Fossil, 21 sp. Eocene-. Brit., France, \&c.

FAMILY IV. CớnIde, Cones.

Shell inversely conical; aperture long and narrow ; outer lip notched at or near the suture; operculum minute, lamellar.

Animal, foot oblong, truncated in front; with a conspicuous (aquiferous ?) pore in the middle. Head produced. Tentacles far apart. Eyes on the tentacles. Gills 2. Lingual teeth (uncini ?) in pairs, elongate, subulate, or hastate.

\section{Conus, L. Cone-shell.}

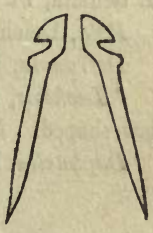

Fig. 72.*

Types, C. marmoreus, pl. VII., fig. 1. C. geographicus, antediluvianus, \&c.

Shell conical, tapering regularly; spire short, many-whirled; columella smooth, truncated in front; outer lip notched at the suture; operculum pointed, nucleus apical.

Distr., 269 sp. All tropical seas. Medit., 2 ; Africa, 23 ; Red Sea, 5 ; Asia, 124; Australia, 16; Pacific, 25 ; Gallapagos, 3; W. America, 20 ; W. Indies and Brazil, 21.

Fossil, 80 sp. Chalk-. Brit., France, India, \&c.

The cones range northward as far as the Mediterranean, and southward to the Cape; but are most abundant and varied in equatorial seas. They inhabit fissures and holes of rocks, and the warm and shallow pools inside coral-reefs, ranging from low water to 30 and 40 fathoms ; they move slowly, and sometimes (C. aulicus) bite when handled; they are all predatory. (Adams.)

Sub-genus. Conorbis, Sw. C. dormitor, Pl. VII., fig. 2. Eocene-. Brit., France.

* Fig.72. Lingual teeth of bela turricula (after Lovén). 


\section{Pleurotoma, Lam.}

Etym., pleura, the side, and toma, a notch. Syn., turris, Humph.

Types, P. Babylonica, Pl. VII., fig. 3. P. mitræformis, \&c.

Shell fusiform, spire elevated; canal long and straight; outer lip with a deep slit near the suture. Operculum pointed, nucleus apical.

Distr., 430 sp. World-wide. Greenland, Brit., 17 ; Medit., 19 ; Africa, 15; Red Sea and India, 6 ; China, 90 ; Australia, 15; Pacific, 0 ? W. America, 52 ; W. Indies and Brazil, 20. The typical sp. about 20 (China, 16; W. America, 4.) Low water to 100 fathoms.

Fossil, 300 sp. Chalk-. Brit., France, \&c. Chile.

Sub-genera. Drillia, Gray. D. umbilicata, canal short.

Clavatula, Lam., canal short, operc. pointed, nucleus in the middle of the inner edge. C. mitra, Pl. VII., fig. 4.

Tomella, Sw., canal long; inner lip callous near suture. T. lineata.

? Clionella, Gray. C. sinuata, Born sp. (= P. buccinoides) freshwaters, Africa.

Mangelia, Leach, (not Reeve). Apertural slit at the suture; no operc., M. tæniata, Pl. VII., fig. 5. Greenland, Brit., Medit.

Bela, Leach. Operc. nucleus apical. B. turricula, Pl. VII., fig. 6.

Defrancia, Millet,* no operc. D. linearis, Pl. VII., fig. 7.

? Lachesis, Risso, L. minima, Pl. VII., fig. 8, apex mammillated; operc. claw-shaped. Medit., S. Brit. In shallow water.

Daphnella, Hinds. D. marmorata. New Guinea. (Buc. junceum. L. clay).

\section{FAMILY V. Volutidx.}

Shell turreted, or convolute; aperture notched in front; columella obliquely plaited. No operculum.

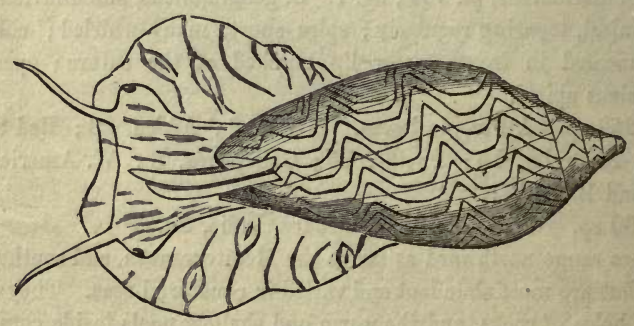

Fig. 73.t

Animal with a recurved siphon; foot very large partly hiding the shell; 
mantle often lobed and reflected over the shell; eyes on the tentacles, or near their base. Lingual ribbon linear; rachis toothed; pleurce unarmed.

Vouuta, L. Volute.

Type, V. musica, Pl. VII., fig. 9.

Syn., cymbiola, harpula, Sw. Volutella, D’Orb. Scapha, \&c., Gray.

Shell ventricose, thick; spire short, apex mammillated; aperture large, deeply notched in front; columella with several plaits. V.musica and a few others have a small operculum.

Animal, eyes on lobes at the base of the tentacles; siphon with a lobe on each side, at its base; lingual teeth 3 cusped.

$V$. vespertilio and hebraa fill the nuclei of their spires with solid shell. $V$. brasiliana forms nidamental capsules 3 inches long. (D'Orb.) In $V$. angulata the mantle is produced into a lobe on the left side, and overlaps the shell.

Distr., 70 sp. W. Indies, Cape Horn, W. Africa, Australia, Java, Chili.

Fossil, 80 sp. Chalk-. India, Brit., France, \&c.

Sub-genera. Volutilithes, Sw. Spire pointed, many-whirled, columella plaits indistinct. V. spinosus, Pl. VII., fig. 10.

Living, 1 sp. ( $V$. abyssicola), dredged at 132 fathoms; off the Cape. (Adams).

Fossil, Eocene. Brit., Paris.

Scaphella, Sw. Fusiform, smooth.

Ex., V. magellanica. Fossil, V. Lamberti, Crag, Suffolk.

Melo, Brod. Large, oval; spire short.

Type, M. diadema, Pl. VII., fig. 11. New Guinea, 8 sp.

Сумва, Broderip. Boat-shell.

Syn., Yetus (Adans.) Gray.

Type, C. proboscidalis, Pl. VII., fig. 12 , and fig. 74 (=V. cymbium, L.)

Shell like voluta; nucleus large and globular; whirls fcw, angular, forming a flat ledge round the nucleus.

The foot of the animal is very large, aud deposits a thin enamel over the under side of the shell. It is ovo-viviparous, and the young animal is very large when born; the nucleus becomes partly concealed by the growth of the shell.

Distr., 10 sp. W. Africa, Lisbon.

Mitra, Lam. Mitre-shell.

Syn., turris, Montf. Zierliana, Gray. Tiara, Sw.

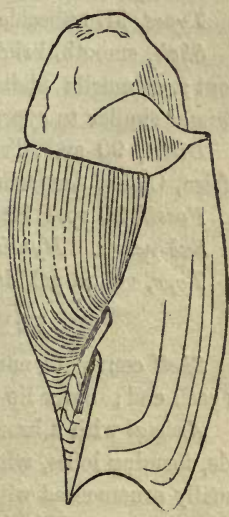

Fig. 74. Cymba. 
Types, M. episcopalis, Pl. VII., fig. 13. M. vulpecula, fig. 14.

Shell fusiform, thick; spire elevated, acute; aperture small, notched in front; columella obliquely plaited; operculum very small.

The animal has a very long proboscis; it emits a purple liquid, having a nauseous odour, when irrritated. The eyes are placed on the tentacles, or at their base. Range, from low water to 15 fathoms, more rarely in $15-80$ fathoms.

Distr., 350 sp. Philippines, India, Red Sea, Medit., W. Africa, Greenland (1 sp.), Pacific, W. America. The extra-tropical species are minute. M. Greenlandica and M. cornea (Medit. sp.) are found together in the latest British Tertiaries (Forbes.)

Fossil, 90 sp. Chalk-. India, Brit., France, \&c.

Sub-genera. Imbricaria, Schum. (conœlix, Sw.)

Shell, cone-shaped. I. conica, Pl. VII., fig. 15.

Cylindra, Schum. (Mitrella, Sw.)

Shell, olive-shaped. C. crenulata, Pl. VII., fig. 16.

Volvaria, Iam.

Etym., volva, a wrapper.

Type, V. bulloïdes, Pl. VII., fig. 17.

Shell cylindrical, convolute; spire minute; aperture long and narrow; columella with 3 oblique plaits in front.

Fossil, 5 ? sp. Eocene. Brit., France.

Marginélla, Lam.

Etym., diminutive of margo, a rim.

Syn., porcellana (Adans.) Gray. Persicula, Schum.

Types, M. nubeculata, Pl. VII., fig. 18. M. persicula, fig. 19.

Shell, smooth, bright; spire short or concealed; aperture truncated in front; columella plaited; outer lip (of adult) with a thickened margin. Animal similar to cypræa.

Distr., 90 sp. Tropical, W. Indies, Brazil, Medit. (1 small sp.) W. Africa, China, Australia.

Fossil, 30 sp. Eocene- France, \&c.

Sub-genus. Hyalina, Schum. Outer lip scarcely thickened.

Type, voluta pallida, Mont., W. Indies.

FAMILY VI. CYPRaIDA. Cowries.

Shell convolute, enamelled; spire concealed; aperture narrow, channelled at each end; outer lip (of adult) thickened, inflected. No operculum.

Animal with a broad foot, truncated in front; mantle expanded on each side, forming lobes, which meet over the back of the shell; these lobes are usually ornamented with tentacular filaments; eyes on the middle of the tentacles or near their base; branchial plume single. Lingual ribbon long, 
partly contained in the visceral cavity; rachis 1 toothed; uncini 3 . The cowries inhabit shallow water, near shore, feeding on zoophytes.

\section{Crprate, L. Cowry.}

Etym., Cypris, a name of Venus.

Types, C. tigris, C. mauritiana, Pl. VII., fig. 20.

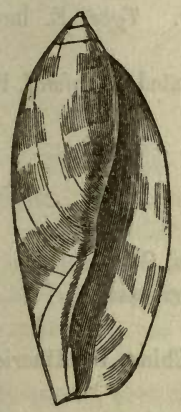

Fig. 75. Cypraa young.*

Shell ventricose, convolute, covered with shining enamel; spire concealed; aperture long and narrow, with a short canal at each end ; inner lip crenulated; outer lip inflected and crenulated. (Lingual uncini similar).

The young shell has a thin and sharp outer lip, a prominent spire, and is covered with a thin epidermis, fig. 75. When fullgrown the mantle lobes expand on each side, and deposit a shining enamel over the whole shell, by which the spire is entirely concealed. There is usually a line of paler colour which indicates where the mantle lobes met. $C y$ prae annulus is used by the Asiatic Islanders to adorn their dress, to weight their fishing-nets, and for barter. Specimens of it were found by Dr. Layard in the ruins of Nimroud.

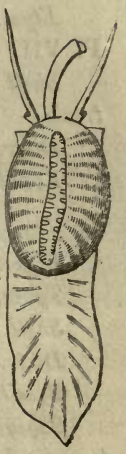

Fig. 76.

Trivia. $\dagger$ The money-cowrey ( $C$. moneta) is also a native of the Pacific and Eastern seas; many tons weight of this little shell are annually imported into this country, and again exported for barter with the native tribes of Western Africa; in the year 1848 sixty tons of the money-cowry were imported into Liverpool; and in 1849 nearly three hundred tons were brought to the same place, according to the statement of Mr. Archer in the Industrial Exhibition. Mr. Adams observed the pteropodous fry of $C$. annulus, at Singapore, adhering in masses to the mantle of the parent, or swimming in rapid gyrations, or with abrupt jerking movements by means of their cephalic fins.

Distr., $150 \mathrm{sp.}$ In all warm seas (except E. coast S. America?) but most abundant in those of the old world. On reefs and under rocks at low water.

Fossil, $78 \mathrm{sp.} \mathrm{Chalk-.} \mathrm{India,} \mathrm{Brit.,} \mathrm{France,} \mathrm{\& c.}$

Sub-genera. Cyprovula, Gray. C. capensis, PI. VII., fig. 21. Apertural plaits continued regularly over the margin of the canal.

Iuponia, Gray. C. algoënsis, Pl. VII., fig. 22. Inner lip irregularly plaited in front.

* Fig. 75. Cypræa testudinaria, L., young, China.

+Fig. 76. Trivia europæa, Mont. From the "British Mollusca," by Messrs. Eorbes and Hanley. 
Trivia, Gray. C. europæa, Pl. VII., fig. 23 ; fig. 76 , and $15, \mathrm{~B}$ Small shells with striæ extending over the back. (Uncini; 1st denticulat 2, 3, simple.)

Distr., 30 sp. Greenland, Brit., W. Indies, Cape, Australia, Pacific, W America.

Erato, Risso.

Etym., Erato, the muse of love-songs and mimicry. Type, E. lævis Pl. VII., fig. 24.

Shell minute; like marginella; lips minutely crenulated. Animal, lik trivia.

Distr., 8 sp. Brit., Medit., W. Indies, China.

Fossil, 2 sp. Miocene-. France, Brit. (Crag.)

Ovulum, Lam.

Etym., dimunitive of ovum, an egg. Syn., amphiceras, Gronov.

Types, 0. ovum, pl. VII., fig. 25. O. gibbosa and verrucosa.

Shell, like cypraa; inner lip smooth.

Distr., 36 sp. Warm seas. W. Indies, Brit., Medit. China, W. America

Fossil, 11 sp. Eocene-. France, \&c.

Sub-genus, calpurna, Leach. O. volva ("The weaver's shuttle"). Aper. ture produced into a long canal at each end. Foot narrow, adapted for walking on the round stems of the gorgonia, \&c., on which it feeds. C patula inhabits the S. coast of Britain, it is very thin, and has a sharp outer lip.

\section{SECTION B. Holostomata. Sea-Snails.}

Shell, spiral or limpet shaped; rarely tubular or multivalve : margin of the aperture entire. Operculum, horny or shelly, usually spiral.

Animal with a short non-retractile muzzle; respiratory siphon wanting, or formed by a lobe developed from the neck (fig. 61), gills pectinated of plume-like, placed obliquely across the back, or attached to the right side of the neck; neck and sides frequently ornamented with lappets and tentacula filaments. Marine or fresh-water. Mostly phytophagous.*

\section{FAMILY I. NATICIDE.}

Shell, globular, few-whirled; spire small, obtuse; aperture, semi-lunar lip, acute; pillar often callous.

Animal, with a long retractile proboscis; lingual ribbon linear; rachis, toothed; uncini, 3 (similar to trivia, fig. 15, B.); foot very large ; mantle-lobs largely developed, hiding more or less of the shell. Species all marine.

* These "sections" are not very satisfactory, but they are better than any othes yet proposed, and they are convenient, on account of the great extent of the ordf proso-branchiata. Natica and scalaria have a retractile proboscis. Pirena has notched aperture, and aporrhais, a canal. 
Natica (Adans.), Lamarck.

Syn., mammilla, Schm. Cepatia, Gray. Nacca, Risso.

Type, N. canrena, Pl. VIII., fig. 1.

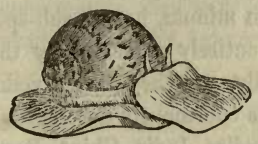

Shell, thick, smooth; inner lip callous; umbilicus large, with a spiral callus ; epidermis thin, polished; operculum sub-spiral.

Animal blind; tentacles connate with a head veil ; front of the large foot provided with a fold (mentum), reflected upon and protecting the head; operc. lobe large, covering part of the shell; jaws horny; lingual ribbon short; branchial plume single.

The coloured markings of the naticæ are very indestructible; they are frequently preserved on fossils. The natica frequent sandy and gravelly bottoms, ranging from low water to 90 fathoms (Forbes). They are carnivorous, feeding on the smaller bivalves (Gould), and are themselves devoured by the cod and haddock. Their eggs are agglutinated into a broad and short spiral band, very slightly attached, and resting free on the sands.

Distr., 90 sp. Arctic seas, Brit., Medit., Caspian, India, Australia, China, Panama, W. Indies.

Fossil, 260 sp. Devonian-. S. America, N. America, Europe, India.

Sub-genera, naticopsis, M‘Coy. N. Phillipsii. Shell imperforate; inner lip very thick, spreading. Operc. shelly (Brit. Mus.). Carb. limestone, 7 sp. Operculum, horny.

Neverita, Risso. N. Alderi. Fig. 77.

Lunatia, Gray. N. Ampullaria. Perforation simple; epidermis dull, olivaceous. Northern seas.

Globulus, J. Sby. (Deshayesia, $\uparrow$ Raulin; Ampullina, Desh. not BI.) N. Sigaretina. Pl. VIII., fig. 2. Umbilicus narrow (rimate), lined by a thin callus. Fossil, eocene. Brit., Paris.

Polinices, Montf., (naticella Guild.) N. mammilla. Shell oblong; callus very large, filling the umbilicus.

Cernina, Gray. N. fluctuata. Pl. VIII., fig. 3. Globular, imperforate ; inner lip callous, covering part of the body whirl.

Naticella, Müller. 19 sp. Fossil, Trias, S. Cassian.

* Fig. 77. Natica Alderi, Forbes. From an original drawing, communicated by Joshua Alder, Esq.

+ Deshayesia was founded on a specimen $v$ ith prominences on the pillar. 


\section{Sigaretus (Adans.), Lamarck.}

Syn., cryptostoma, Bl. Stomatia, Browne.

Type, S. haliotoïdes. Pl. VIII., fig. 4.

Shell, striated; ear-shaped; spire minute; aperture very wide, oblique (not pearly). Operculum minute, horny, sub-spiral.

The flat species are entirely concealed by the mantle when living; the convex shells only partially, and they have a yellowish epidermis. The anterior foot lobe (mentum) is enormously developed.

Distr., 26 sp. W. Indies, India, China, Peru.

Fossil, 10 sp. Eocene-. Brit., France, S. America.

Sub-genus, naticina, Gray. N. papilla, pl. VIII., fig. 3. Shell ventricose, thin, perforated. W. Indies, Red Sea, China, N. Australia, Tasmania. Eocene, Paris.

LaMellaria, Montagu.

Etym., lamella, a thin plate.

Syn., marsenia, Leach. Coriocella, Bl.

Type, L. perspicua. PI. VIII., fig. 6.

Shell ear-shaped; thin, pellucid, fragile; spire very small; aperture large, patulous; inner lip receding. No operc.

Animal much larger than the shell, which is entirely concealed by the reflected margins of the mantle; mantle non-retractile, notched in front; eyes at the outer bases of the tentacles. Lingual uncini 3 , similar; or one very large.

Distr., 5 sp. Norway, Brit., Medit., New Zealand, Philippines.

Fossil, 2 sp. Miocene-. Brit. (Crag.)

Narica, Recluz.

Syn., vanicoro, Quoy. Merria, Gray. Leucotis, Sw.

Type, N. cancellata. Pl. VIII., fig. 8.

Shell thin, white, with a velvety epidermis; ribbed irregularly, and spirally striated; axis perforated. Operc. very small, thin.

Animal, eyes at the outer base of the tentacles; foot with wing-like lobes,

Distr., 6 sp. W. Indies, Nicobar, Vanikoro, Pacific.

Fossil, 4 sp. Gault-(D’Orb.) Brit., France.

Velutrina, Fleming.

Etym., velutinus, velvety (from vellus, a fleece).

Type, V. lævigata. Pl. VIII., fig. 7.

Shell thin ; with a velvety epidermis; spire small; suture deep; aperture very large, rounded; peristome continuous, thin. No operc.

Animal with a large oblong foot; margin of the mantle developed all round, and more or less reflected over the shell; gills 2 ; head broad; tentacles subulate, blunt, far apart; eyes on prominences at their outer bases. Carnivorous. Lingual dentition like trivia (fig. 15, B.). 
Distr., 4 sp. Britain, Norway, N. America, Icy sea to Kamtschatka. living on stones near low water, and ranging to 30 fms.

Fossil, 3 sp. Miocene-. Brit.

Sub-genus. Otina (Gray). V. otis. Shell minute, ear shaped. Animal like velutina, but with a simple mantle, and very short tentacles. W. and S. W. Brit. coast ; inhabiting chinks of rocks, between tide-marks (Forbes).

\section{Family II. Pyramidellide.}

Shell spiral, turreted; nucleus minute, sinistral; aperture small; columella sometimes with one or more prominent plaits. Operculum horny, imbricated, nuclus internal.

Animal with broad ear-shaped tentacles, often connate; eyes behind the tentacles, at their bases; proboscis retractile; foot truncated in frout; tongue unarmed. Species all marine.

Several genera of fossil shells are provisionally placed in this order, from their resemblance to eulima and chemnitzia.* Tornatella, usually placed in or near this family, is opistho-branchiate.

\section{Pyramidélita, Lam.}

Etym., dimunitive of pyramis, a pyramid.

Syn., obeliscus, Humph. (P. dolabrata. Pl. VIII., fig. 11.)

Type, P. auris-cati. Pl. VIII., fig. 10.

Shell slender, pointed, with numerous plaited or level whirls; apex sinistral; columella with several plaits; lip sometimes furrowed internally. Operc. indeuted on the inner side to adapt it to the columellar plaits. The shell of the typical pyramidellæ bears some resemblance to cancellaria.

Distr., 11 sp. W. Indies, Mauritius, Australia.

Fossil, 12 sp. Chalk ?-. France, Brit.

\section{Odostomia, Fleming, 1824.}

Etym., odous, a tooth, and stoma, mouth.

Type, O. plicata, Pl. VIII., fig. 12.

Shell subulate or ovate, smooth; apex sinistral; aperture ovate; peristome not continuous; columella with a single tooth-like fold; lip thin; operculum horny, indented on the inner side.

Distr., sp. Brit., Medit., Red Sea, Australia.

Fossil, 15 sp.? Eocene-. Brit., France.

Very minute and smooth shells, having the habit of rissoa, and like them sometimes found in brackish water. They range from low water to $40 \mathrm{fms}$. The animal is undistinguishable from chemnitzia.

* "The Pyramidellide present subjects of much interest to the student of extinct mollusea; numerous forms, bearing all the aspect of being members of this family, occur among the fossils of even the oldest stratified rocks. Many of them are gigantic compared with existing species, and the group, as a whole, may be regarded, rather as appertaining to past ages than the present epoch." (Forbes.) 
Chematrzia, D’Orbigny.

Etym., named in honour of Chemnitz, a distinguished conchologist of Nuremburg, who published seven volumes in continuation of Martini's "Conchylien-Cabinet," 1780-95.

Syn., turbonilla, Risso. Parthenia, Lowe. Pyramis and Jaminea, Br. Nonoptigma, Gray. Amoura, Moller.

Type, C. elegantissima. Pl. VIII., fig. 13.

Shell slender, elongated, many-whirled; whirls plaited; apex sinistral ; aperture simple; ovate; peristome incomplete; operculum horny, sub-spiral.

Animal, head very short, furnished with a long, retractile proboscis ; tentacles triangular; eyes immersed at the inner angles of the tentacles; foot truncated in front, with a distinct mentum.

Distr., Brit. (4 sp.), Norway, Medit. Probably world-wide. Range from low water to 90 fms.

Fossil, 180 sp. Permian- Brit., France, \&c.

The "melania" of the secondary rocks are provisionally referred to this genus. Those of the palæozoic strata to loxonema.

Sub-genus. Eulimella, Forbes. E. scillæ, Scacchi. 4. Brit. sp. Shell smooth and polished; columella simple; apex sinistral.

\section{Eulima, Risso, 1826.}

Etym., eulimia, ravenous hunger. Syn., pasithea, Lea.

Type, E. polita. Pl. VIII., fig. 14.

Shell small, white, and polished; slender, elongated, with numerous level whirls; obscurely marked on one side by a series of periodic mouths, which form prominent ribs internally; apex acute; apertwe oval, pointed above; outer lip thickened internally; inner lip reflected over the pillar. Operculum horny, sub-spiral.

Animal, tentacles subulate, close, with the eyes immersed at their posterior bases; proboscis long, retractile; foot truncated in front, mentum bilobed; operc. lobe winged on each side; branchial plume single; mantle with a rudimentary siphonal fold.

The eulimæ creep with the foot much in advance of the head, which is usually concealed within the aperture, the tentacles only protruding. (Forbes.)

Distr., 15 sp. Brit., Medit., India, Australia, Pacific. In 5-90 fms. water.

Fossil, 40 sp. Carb.?-. Brit., France, \&c.

Sub-genus. Niso, Risso (=Bonellia, Desh.). N. terebcllatus, Lam. sp. Axis perforated.

Fossil, 3 sp. Eocene -. Paris. Distr., 5 sp. China, W. America (Cuming).

Struina, Fleming.

Ex., S. astericola. Pl. VIII, fig. 15. (Syn. stylifer, Brod.) 
Shell, hyaline, globular or subulate, apex tapering, styliform, nucleus sinistral.

Animal with slender, cylindrical tentacles, and small sessile eyes at their outer bases; mantle thick, reflected over the last whirls of the shell; foot large, with a frontal lobe. Branchial plume single. Attached to the spines of sea-urchins, or immersed in living star fishes and corals.

Distr., 6 sp. W. Indies, Brit., Philippines, Gallapagos.

\section{Loxonema, Phillips.}

Etym., loxos, oblique, and nema, thread; in allusion to the striated surface of many species.

Shell elongated, many-whirled; aperture simple, attenuated above, effused below, with a sigmoidal edge to the outer lip.

Fossil, 75 sp. L. silurian-Trias. N. America, Europe.

Macrocheilus, Phillips.

Etym., macros, long, and cheilos, lip.

Shell, thick, ventricose, buccinoid; aperture simple, effuse below; outer lip thin, inner lip wanting, columella callous, slightly tortuous.

Type, M. arculatus, Schlotheim sp. Devonian. Eifel.

Fossil, 12 sp. Devonian-Carboniferous. Brit., Belgium.

FAMily III. Cerithiade. Cerites.

Shell spiral, elongated, many-whirled, frequently varicose; aperture channelled in front, with a less distinct posterior canal; lip generally expanded in the adult; operculum horny and spiral.

Animal with a short muzzle, not retractile; tentacles distant, slender; eyes on short pedicels, connate with the tentacles; mantle-margin with a rudimentary siphonal fold; tongue armed with a single series of median teeth, and three laterals or uncini; marine, estuary, or fresh-water.

Cerithium (Adans.). Bruguiere.

Etym., ceration, a small horn.

Type., C. nodulosum. Pl. VIII., fig. 16.

Shell turreted, many-whirled, with indistinct varices; aperture small, with a tortnous canal in front; outer lip expanded; inner lip thickened. Operculum horny, paucispiral. P1. VIII., fig. 16*.

Distr., above $100 \mathrm{sp}$. World-wide, the typical species tropical. Norway, Brit., Medit., W. Indies, India, Australia, China, Pacific, Gallapagos.

Fossil. 460 sp. Trias -. Brit., France, U. States, \&c.

Sub-genera. Rhinoclavis, Sw. C. vertagus. Canal long, bent abruptly operc., sub-spiral.

Bittium, Leach. C. reticulatum, Pl. VIII., fig. 17. Small northern species, ranging from low-water to 80 fathoms. 
Triphoris, Deshayes. C. perversum, Pl. VIII., fig. 18. 30 sp. Norway -Australia. Fossil. Eocene-. Brit., France. Shell sinistral; anterior and posterior canals tubular. The third canal is only accidentally present, forming part of a varix.

Cerithiopsis, Forbes. C. tuberculare, Brit. Shell like bittium; proboscis retractile; operculum pointed, nucleus apical. Range $4-40 \mathrm{fms}$.

Potamides, Brongniart. Fresh-water Cerites.

Etym., potamos, a river, and eidos, species.

Type., P. Lamarckii, Brong. (= Cerit. tuberculatum, Brard.)

Ex., P. mixtus. Pl. VIII., fig. 19.

Syn., tympanotomus, Klein, C. fuscatum, Africa. Pirenella, Risso, C. mammillatum, Pl. VIII., fig. 22.

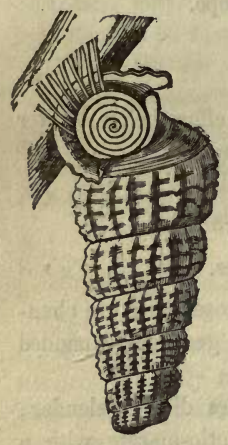

Fig. 78. Cerithidea.*

Shell like cerithium, but without varices, in the very numerous typical fossil species; epidermis thick, olivebrown; operculum orbicular, many-whirled.

Distr., old world only? Africa, India. In the mud of the Indus they are mixed with sp. of ampullaria, venus, purpura, vulsella, \&c. (Major W. E. Baker.)

Fossil (sp. included with cerithium) Eocene-. Europe.

Sub-genera. Cerithidea. Sw., C. decollata, Pl. VIII., fig. 24. Aperture rounded: lip expanded, flattened. Inhabit salt-marshes, mangrove swamps, and the mouths of rivers; they are so commonly ont of the water as to have been taken for land-shells. Mr. Adams noticed them in the fresh-waters of the interior of Borneo, creeping on pontederia and sedges; they often suspend themselves by glutinous threads, fig. 78 .

Distr. India, Ceylon, Singapore, Borneo, Philippines, Port Essington.

Terebralia, Sw. Cerith, Telescopium, PI. VIII., fig. 21.

Shell pyramidal; columella with a prominent fold, more or less continuous towards the apex ; and a second, less distinct, on the basal front of the whirls (as in nerincea, fig. 79). India, N. Australia.

T. telescopium is so abundant near Calcutta, as to be used for burning: into lime; great heaps of it are first exposed to the sun, to kill the animals. They have been brought alive to England (Benson).

Pyrazus, Montf. Cerit, palustre, Pl. VIII., fig. 20.

Shell with numerous indistinct varices; canal straight, often tubular; outer lip expanded. India, N. Australia.

Cerith radulum and granulatum of the W. African rivers approach very nearly the fossil potamides, but they have numerous varices. 
Lampania, Gray (batillaria, Cantor). Cerith, zonale. Pl. VIII., fig. 23. Shell without varices, canal straight. Chusan.

The fossil potamides decussatus, Brug., of the Paris basin, resembles this section, and retains its spiral red bands.

Nerinea, Defrance.

Etym., nereis, a sea-nymph.

$E x$., N. trachea. Fig. 79 .

Shell elongated, many-whirled, nearly cylindrical; aperture channelled in front; interior with continuous ridges on the columella and whirls.

Fossil, 150 sp. Inf. oolite-U. chalk. Brit., France, Germany, Spain, and Portugal. They are most abundant, and attain the largest size to the south; and usually occur in calcarious strata, associated with shallow-water shells. (Sharpe.)

Sub-genera. 1. Nerinaa. Folds simple: $2-3$ on the co lumella; $1-2$ on the outer wall; columella solid, or perforated. Above 50 sp.

2. Nerinella (Sharpe), columella solid; folds simple; columellar, $0-1$; outer wall 1 .

3. Trochalia (Sharpe), columella perforated, with one fold; outer wall simple, or thickened, or with one fold ; folds simple.

4. Ptygmatis (Sharpe), columella solid or perforated, usually with 3 folds; outer wall with $1-3$ folds, some of them complicated in form.

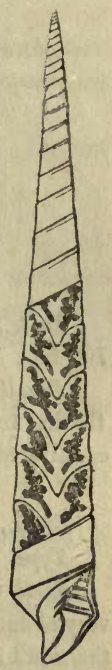

Fig. 79.*

\section{P Fastigiella, Reeve.}

Type, F. carinata, Reere.

Shell like turritella ; aperture with a short canal in front (Mus., Cuming, and Brit. M.).

APORRHAIS, Aldrovandus.

Etym., aporrhais (Aristotle) "spout-shell" from aporrheo, to flow away. Syn., chenopus Philippi.

Type, A. pes-pelecani. Pl. IV., fig. 7, and fig. 80.

Shell with an elongated spire; whirls numerous, tuberculated; aperture narrow, with a short canal in front; outer lip of the adult expanded and lobed or digitated; operc. pointed, lamellar.

Animal with a short broad muzzle; tentacles cylindrical, bearing the eyes on prominences near their bases, outside; foot short, angular in front;

* Fig. 79. Nerinæa trachea, Desl., partly ground down to shew the form of the interior. Bath oolite, Ranville. Communicated by John Morris, Esq. 
branchial plume single, long; lingual ribbon linear; teeth single, hooked, denticulated; uncini 3 , the first transverse, 2 and 3 claw-shaped.

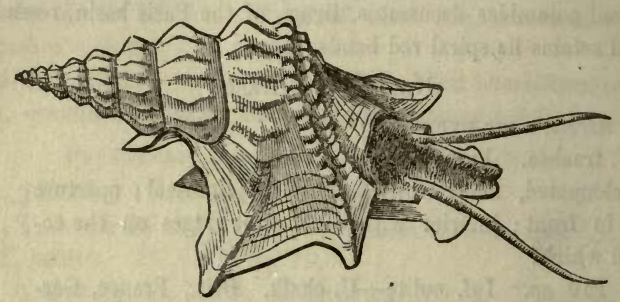

Fig. 80.*

Distr., 3 sp. Labrador, Norway, Brit., Medit. W. Africa. Range,100 fms.

Fossil; see Pteroceras and Rostellaria; above 200 species, ranging from the lias to the chalk, probably belong to this genus, or to genera not yet constituted.

\section{Struthiolaria, Lam.}

Etym., struthio, an ostrich (-foot), from the form of its aperture.

Type, S. straminea, Pl. IV., fig. 6.

Shell turreted; whirls angular; aperture truncated in front; columella very oblique; outer lip prominent in the middle, reflected and thickened in the adult; inner lip callous, expanded; operculum claw-shaped, curved inwards, with a projection from the outer, concave edge.

Animal with an elongated muzzle? tentacles cylindrical; eye-pedicels short, adnate with the tentacles, externally; foot broad and short. (Kiener.)

Distr., 5 sp. Australia and New Zealaud; where alone it occurs subfossil.

\section{FAMily IV. Melaniade.}

Shell spiral, turreted; with a thick, dark epidermis; aperture often channelled, or notched in front; outer lip acute; operculum horny, spiral. The spire is often extensively croded by the acidity of the water in which the animals live.

Animal with a broad non-retractile mpzzle; tentacles distant, subulate; eyes on short stalks, united to the outer sides of the tentacles; foot broad and short, angulated in front; mantle-margin fringed; tongue long and lincar, with a median and 3 lateral series of hooked multi-cuspid teeth. Often viviparous. Inhabiting fresh-water lakes and rivers throughout the warmer parts of the world. Only fossil in Britain.

* Fig. 80. Aporrhais pes-pelecani, L., from a drawing by Joshua Alder, Esq., n the "British Mollusca." 


\section{Melania, Lam.}

Etym., Melania, blackness (from melas).

Type, M. amarula. Pl. VIII., fig. 25.

Syn. Thiara, Megerle. Pyrgula, Crist.

Shell turreted, apex acute (unless eroded); whirls ornamented with striæ or spines; aperture oval, pointed above: outer lip sharp, sinuous; operculum subspiral. Pl. VIII., fig. 25*.

Distr., 160 sp. S. Europe, India, Philippines, Pacific Islands. Distinct groups in the southern states of N. America.

Fossil, 25 sp. Eocene-. Europe (v. chemnitzia).

Sub-genera. Melanàtria, Bowdich. M. fluminea* Pl. VIII., fig. 26. Aperture somewhat produced in front; operculum with rather numerous whirls. This section includes some of the largest sp. of the genus, and is well typified by the fossil, M. Sowerbii (cerit. melanoides, Sby.) of the Woolwich sands. Old World, India, Philippines.

Vibex, Oken, V. fuscatus, Pl. VIII., fig. 29. V. auritus. W. Africa. Whirls spirally ridged, or muricated; aperture broadly channelled in front.

Ceriphasia, Sw., C. sulcata. N. America. A perture like vibex; slightly notched near the suture.

Hemisinus, Sw., H. lineolatus. W. Indies. Aperture channelled in front.

Melafùsus, Sw. (Io, Lea. Glottella, Gray.) M. fluviatilis. Pl. VIII., fig. 27. U. States. Aperture produced into a spout in front.

Melàtoma, Anthony (not Sw.) M. altilis. Shell like anculotus; with a deep slit at the suture. U. States.

Anculotus, Say. A. præmorsus. Pl. VIII., fig. 28. Shell globular; spire very short; outer lip produced. U. States.

Amnicola, Anthony. A. isogona. Pl. IX., fig. 23. U. States.

? Pachystoma, Gray. M. marginata, Eocene. Paris. Peristome thickened externally, all round.

\section{Paludomus, Swainson.}

Etym., palus, a marsh, and domus, home.

Syn., tanalia, Gray. Hemimitra, Sw.

Type, P. aculeatus, Gm. sp. Pl. IX., fig. 34 .

Shell, turbinated, smooth or muricated; with wavy stains beneath the olive epidermis; spire small, usually eroded ; operc. horny, lamellar, nucleus external. Animal like melania ; mantle-margin fringed (Eydoux).

Distr., $10 \mathrm{sp.} \mathrm{Ceylon} \mathrm{(Himalaya} \mathrm{?)} \mathrm{in} \mathrm{the} \mathrm{mountain-streams,} \mathrm{sometimes}$ at an elevation of 6,000 feet. The Himalayan sp. (melania conica, Gray,

* This is a good section of melania, but Mr. Gray's type does not well represent it, being more like a pirena in the form of its aperture. 
hemimitra retusa, Sw., and several others), referred to this genus, have a concentric operculum, like paludina.

\section{Melanópsis, Lam.}

Types, M. buccinoides, M. costata. Pl. VIII., fig. 30.

Shell; body-whirl elongated; spire short and pointed; aperture distinctly notched in front; inner lip callous; operculum sub-spiral.

Distr., 20 sp. Spain, Asia Minor, New Zealand.

Fossil, 25 sp. Eocene-. Europe.

Sub-genus. Piréna, Lam. (faunus, Montf.) P. atra. Pl. VIII., fig. 31. Spire elongated, many whirled; outer lip of the adult produced.

Distr., 4 sp. ? S. Africa, Madagascar, Ceylon, Philippines.

\section{FAMILY V. TURritellide.}

Shell tubular, or spiral; upper part partitioned off; aperture simple; operculum horny, many-whirled.

Animal with a short muzzle; eyes immersed, at the outer bases of the tentacles; mantle-margin fringed; foot very short; branchial plume single; tongue armed.

TuRritélla, Lam.

Etym., diminutive of turris, a tower.

Syn., terebellum, torcula, zaria and eglisia, Gray.

Type, T. imbricata. Pl. IX., fig. 1.

Shell elongated, many-whirled, spirally striated; aperture rounded, margin thin; operculum horny, many-whirled; with a fimbriated margin.

Animal with long, subulate tentacles; eyes slightly prominent; foot truncated in front, rounded behind, grooved beneath; branchial plume very long; lingual ribbon minute; median teeth hooked, denticulated; uncini 3, serrulated. Carnivorous?

Distr., $50 \mathrm{sp.}$ World-wide. Ranging from the Laminarian Zone to 100 fms. W. Indies, U. States, Brit. (1 sp.), Iceland, Medit., W. Africa, China, Australia, W. America.

Fossil, 170 sp., Neocomian-. Brit. \&c., S. America, Australia.

Sub-genera. Proto, Defr., P. cathedralis, Pl. IX., fig. 3, aperture truncated below.

Mesalia, Gray, M. sulcata (var.) Pl. IX., fig. 2. Greenland-S. Africa.

Fossil, Eocene. Brit., France.

\section{? AcLis, Lovén.}

Etym., $A$, without, kleis, a projection.

Syn., alvania, Leach (not Risso).

Type, A. perforatus, Mont. Pl. IX., fig. 4.

Shell minute, like turritella; spirally striated; aperture oval; outer lip prominent; axis slightly rimate; operculate. 
Animal with a long retractile proboscis; tentacles close together, slender, inflated at the tips; eyes immersed at the bases of the tentacles; operc. lobe ample, unsymmetrical ; foot truncated in front. Ranges to 80 fathoms water. 3 Brit. sp. Norway.

Fossil. ? sp., Miocene-. Brit. (Crag).

Cecum, Fleming.

Syn., corniculina, Münster. Brochus, Bronn. Odontidium, Phil.

Type, C. trachea, Pl. IX, fig. 5. Young sp., fig. 6.

Shell at first discoidal, becoming decollated when adult; tubular, cylindrical, arched; aperture round, entire; apex closed by a mammillated septum. Operc. horny, many-whirled. Lingual teeth, 0 ; uncini, 2 , the inner broad and serrulated.

Distr., Brit., 2 sp., 10 fathoms. Medit.

Fossil, 4 sp. Eocene-. Brit., Castelarquato.

Vermetus, Adanson. Worm-shell.

Syn., siphonium, Gray. Serpuloides, Sassi.

Types, V. lumbricalis, Pl. IX., fig. 7.

Shell tubular, attached; sometimes regularly spiral when young; always irregular in its adult growth; tube repeatedly partitioned off ; aperture round; operc. circular, concave externally.

Distr., Portugal, Medit., Africa, India.

Fossil, 12 sp. Neocomian-. Brit., France, \&c.

? Sub-genus. Spiroglyphus, Daud. S. spirorbis Dillw. sp., irregularly tubular; attached to other shells, and half buried in a furrow which it makes as it grows. Perhaps an annelide?

Siliquaria, Brug.

Etym., siliqua, a pod.

Type, S. anguina, Pl. IX., fig. 8.

Shell tubular; spiral at first, irregular afterwards; tube with a continuous longitudinal slit.

Distr., 7 sp. Medit., N. Australia. Found in sponges.

Fossil, 10 sp. Eocene-. France, \&c.

Scalaria, Lam. Wentle-trap.

Etym., scalaris, like a ladder. Type, S. pretiosa, Pl. IX., fig. $9(=\mathrm{T}$. scalaris, L.)

Shell, mostly pure white and lustrous; turreted; many-whirled; whirls round, sometimes separate, ornamented with numerous transverse ribs; aperture round; peristome continuous. Operc. horny, few-whirled.

Animal with a retractile proboscis-like mouth; tentacles close together, long and pointed, with the eyes near their outer bases; mantle-margin simple, 
with a rudimentary siphonal fold; foot obtusely triangular, with a fold ' $m e n$ tum) in front. Lingual dentition nearly as in bulla; teeth 0 ; uncini numerous, simple; sexes distinct; predacious? Range from low water to 80 fathoms. The animal exndes a purple fluid when molested.

Distr., nearly $100 \mathrm{sp}$. Mostly tropical. Greenland, Norway, Brit., Medit., W. Indies, China, Australia, Pacific, 'W. America.

Fossil, nearly 100 sp. Coral-rag-. Brit., N. America, Chile, India.

\section{FAMILY VI. LTTORINIDA.}

Shell spiral, turbinated or depressed, never pearly; aperture rounded; peristome entire; operculum horny, pauci-spiral.

Animal with a muzzle-shaped head, and eyes sessile at the outer bases of the tentacles; tongue long, armed with a median series of broad, hooked teeth, and 3 oblong, hooked uncini. Branchial plume single. Foot with a linear duplication in front, and a groove along the sole. Mantle with a rudimentary siphonal canal ; operc. lobe appendaged.

The species inhabit the sea, or brackish water, and are mostly litoral, feeding on algæ.

\section{Litorina, Férussac. Periwinkle.}

Etym., litus, the sea-shore.

Type, L. litorea, Pl. IX., fig. 10.

Shell turbinated, thick, pointed, few-whirled; aperture rounded, outer lip acute, columella rather flattened, imperforate, operculum pauci-spiral, fig. 81. Lingual teeth hooked and trilobed; uncini hooked and dentated.

Distr., $40 \mathrm{sp}$. The periwinkles are found on the sea-shore, in all parts of the world. In the Baltic they live within the in-

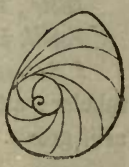

Fig. 81 . fluence of fresh-water, and frequently become distorted; similar monstrosities are found in the Norwich crag.

The common sp. (L. litorea) is oviparous; it inhabits the lowest zones of sea-weed between tide-marks. An allied sp. ( $L$. rudis) frequents a higher region, where it is scarcely reached by the tide; it is viviparous, and the young have a hard shell before their birth, in consequence of which the species is not eaten. The tongue of the periwinkle is two inches long; its foot is divided by a longitudinal line, and in walking the sides advance alternately. The periwinkle and trochus are the food of the thrush, in the Hebrides, during winter.

Fossil, $10 \mathrm{sp}$ ? Miocene-. Brit., \&c. It is probable that a large proportion of the oolite and cretaceous shells referred to turbo, belong to this genus, and especially to the section tectaria.

Sub-genera. Tectaria, Cuvier, 1817 (= Pagodella, Sw.) L. pagodus, P1. IX., fig. 11. Shell muricated or granulated; sometimes with an umbilical 
fissure. Operc. with a broad, membranous border. W. Indies, Zanzibar, Pacific.

Modulus, Gray (and nina, Gray) M. tectum, Pl. IX., fig. 13. Shell tro. chiform or naticoid; porcellanous; columella perforated; inner lip worn or toothed; opere. horny, many-whirled. Distr., Philippines, W. America.

Fossarus (Adans.) Philippi. F. sulcatus, Pl. IX., fig. 12. Syn., phasianema, Wood. Shell perforated; inner lip thin; operc. not spiral. Distr., Medit. Fossil, 3 sp. Miocene-. Brit., Medit.

Risella, Gray. Lit., melanostoma, Pl. IX., fig. 14. Shell trochiform, with a flat or concave base; whirls keeled; aperture rhombic, dark or variegated, operc. pauci-spiral. Distr., N. Zealand.

Solarium, Lam. Stair-case shell.

Etym., solarium, a dial.

Syn., architectoma, Bolten. Philippia, Gray. Helicocryptus, D’Orb?

Type., S. perspectivum, Pl. IX., fig. 15.

Shell orbicular, depressed; umbilicus wide and deep; aperture rhombic; peristome thin; operculum horny, sub-spiral.

The spiral edges of the whirls, seen in the umbilicus, have been fancifully compared to a winding stair-case.

Distr., 25 sp. Tropical seas. Medit., E. Africa, India, China, Japan, Australia, Pacific, W. America.

Fossil, 56 sp. Eocene-. Brit., \&c. 26 other sp. (oolites-chalk,) are provisionally referred to this genus; the cretaceous sp. are nacreous ( $v$. trochus).

Sub-genera. Torinia, Gray. T. cylindracea, operc. conical, multi-spiral, with projecting edges, fig. 82. Living, New Ireland. Fossil, Eocene. Brit. Paris.

Omalaxis, Desh. (altered to bifrontia) S. bifrons, discoidal, the last whirl disengaged. $6 \mathrm{sp}$. Eocene, Paris, Brit.

? Orbis, Lea. Discoidal, whirls quadrate. Fossil, Eocene, America.

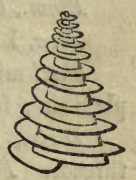

Fig. 82.*

\section{? Phorus, Montf. Carrier-shell.}

Etym., phoreus, a carrier.

Syn., onustus, Humph., Xenophorus, Fischer.

Examples, P. conchyliophorus, Born. P. corrugatus, Pl. X., fig. 1.

Shell trochiform, concave beneath; whirls flat, with foliaceous or stellated margins, to which shells, stones, \&c., are usually affixed; aperture very oblique, not pearly; outer lip thin, much produced above, receding far beneath. Operc. horny, imbricated, nucleus external (as in purpura and paludomus,) with the transverse scar seen through it, fig. 83. (Mus. Cuming.)

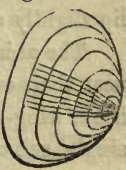

Fig. 83.

* Operculum of S. patulum, Lam. $\frac{3}{1}$, from Deshayes. 
Animal with an elongated (non-retractile?) proboscis ; tentacles long and slender, with sessile eres at their outer bases; sides plain; foot narrow, elongated behind. (Adams.) Related to scalaria?

Most of the phori attach foreign substances to the margins of their shells, as they grow; particular species affecting stones, whilst others prefer shells or corals. They are called "mineralogists," and " conchologists," by collectors ; P. solaris and P. indicus are nearly or quite free from these disguises. They are said to frequent rough bottoms, and to scramble over the ground, like the strombs, rather than glide evenly.

Distr., 9 sp. W. Indies, India, Malacca, Philippines, China, W. America.

Fossil, 15 sp. Chalk ?-Eocene-. Brit., France. Shells extremely like the recent phorus, are met with even in the carb. limestone.

Lacuna, Turton.

Etym., lacuna, a fissure.

Type, L. pallidula, Pl. IX., fig. 16. Syn., medoria, Gray.

Shell, turbinated, thin; aperture semi-lunar; columella flattened, with an umbilical fissure. Operc. pauci-spiral.

Animal, operculigerous lobe furnished with lateral wings and tentacular filaments. Teeth, 5 cusped; uncini 1, 2 dentated, 3 simple. Spawn (ootheca) vermiform, thick, semicircular. Range, low-water- 50 fathoms.

Distr., Northern shores, Norway, Brit., Spain. Fossil, 1 sp. Glacial beds, Scotland.

\section{? LITIOPA, Rang.}

Etym., litos, simple, ope, aperture.

Type, L. bombix. Pl. IX., fig. 24.

Shell minute, pointed; aperture slightly notched in front; outer lip simple, thin; inner lip reflected. Operc. spiral.

Distr., Atlantic, Medit., on floating sea-weed, to which they adhere by threads. Fossil, 1 sp. Miocene (Crag.).

\section{RissoA, Frémenville.}

Etym., named after Risso, ${ }^{*}$ a French zoologist.

Type, R. labiosa, Pl. IX., fig. 17. Syn., cingula, Flem.

Shell minute, white or horny ; conical, pointed, many-whirled; smooth, ribbed, or cancellated; aperture rounded; peristome entire, continuous ; outer lip slightly expanded and thickened. Operc. sub-spiral.

The animal has long, slender tentacles, with eyes on small prominences, near their onter bases; the foot is pointed behind; the operculigerous lobe has a wing-like process and a filament (cirrus) on each side. Lingual teeth single, sub-quadrate, hooked, dentated; uncini $3 ; 1$ dentated, 2, 3, claw-

- It is much to be regretted that some modern naturalists have tried to find out and bring into use the obscure genera of Risso, and the worthless fabrications of Montfort and Rafinesque, which had better have remained unknown. 
shaped. They range from high-water to 100 fathoms, but abound most in shallow water, near shore, on beds of fucus and zostera.

Distr., about $70 \mathrm{sp}$. Universally distributed, but most abundant in the north temperate zone. N. America, W. Indies, Norway, Brit., Medit., Caspian, India, \&c. Rissoa parva adheres to sea-weeds, by threads, like litiopa (Gray).

Fossil, 100 sp. Permian-. Brit., France, \&c.

Sub-genera. Rissoina, D'Orb. Aperture channelled in front. Living and Fossil (10 sp. Bath oolite.- Brit.)=Tuba, Lea? America.

Hydrobia, Hartm. (=Paludinella, Lovén. Paludestrina, D'Orb.) Shell smooth; foot roanded behind; operc. lobe without filament. Type, litorina ulvæ, Pl. IX., fig. 18. Fossil, 10 sp. Wealden-. Brit., \&c.

Syncera, Gray (Assiminea, Leach). S. hepatica. Shell like Hydrobia; tentacles connate with the eye pedicels, which equal them in length. Teeth 5-7 cusped; uncini 1, 2, dentated, 3 rounded. Distr., brackish water. Brit., India.

Nematura, Benson. N. deltæ. Pl. IX, fig. 21. Aperture contracted; peristome entire. Operc. pauci-spiral. Fossil, eocene. Isle of Wight.

Jeffreysia, Alder (=Rissoëlla, Gray, MS.), J. diaphana. Shell minute, translucent. Operc. semilunar, imbricated, with a projection from the straight, inner side. (Pl. IX., fig. 19.) Head elongated, deeply cleft, and produced into two tentacular processes; mouth armed with denticulated jams, and a spinous tongue; tentacles linear, eyes far behind, prominent, only visible through the shell; foot bi-lobed in front. $2 \mathrm{sp}$. Brit. On sea-weed, near low water (Alder).

\section{SkExed, Fleming.}

Etym., named after Dr. Skene of Aberdeen; a cotemporary of Linnæus. Syn., delphinoïdea, Brown.

Type, S. planorbis, Pl. IX., fig. 20.

Shell minute orbicular, depressed, few-whirled; peristome continuous, entire, round. Operc. pauci-spiral. Animal like rissoa, foot rounded behind. Found under stones at low-water, and amongst the roots of corallina officinalis.

Distr., ? sp. Northern seas. Norway, Brit.

P Truncatelua, Risso. Iooping-snail.

Type, T. truncatula. Pl. IX., fig. 25. (Mus., Hanley.)

Shell minute, cylindrical, truncated; whirls striated transversely; aperture oval, entire; peristome continuous. Operculum sub-spiral!

Animal with short, diverging triangular tentacles; eyes centrally behind: head bi-lobed; foot short, rounded at each end (Forbes).

The truncatellæ are found on stones and sea-weeds between tide-marks, and survire many weeks out of the water (Lorre). They walk by contracting 
the space between their lips and foot, like the geometric caterpillars (Gray). They are found semi-fossil, along with the human skeletons in the modern limestone of Guadaloupe.

Distr., 15 sp. W. Indies, Brit., Medit., Rio, Cape, Mauritius, Philippines, Australia, Pacific (Cuming).

\section{? Lithoglyphus, Megerle.}

Type, L. fuscus. Pl. IX., fig. 22.

Shell naticoid, often eroded; whirls few, smooth; aperture large, entire; peristome continuous, outer lip sharp, inner lip callous; umbilicus rimate; epidermis olivaceous; operculum pauci-spiral.

Distr., sp. Europe, Oregon.

\section{FAMILY VII. Paludinida.}

Shell conical or globular, with a thick, olive-green epidermis; aperture rounded; peristome continuous, entire ; operculum horny or shelly, normally concentric.

Animal with a broad muzzle; tentacles long and slender; eyes on short pedicels, outside the tentacles. Inhabiting fresh-waters in all parts of the world.

Paludina, Iram. River-snail.

Etym., palus (paludis) a marsh. Syn., viviparus, Gray.

Type, P. Listeri. Pl. IX., fig. 26. (P. vivipara, fig. 61.)

Shell turbinated, with round whirls; aperture slightly angular behind; peristome continuous, entire; operc. horny, concentric. Animal with a long muzzle, and very short eye-pedicels; neck with a small lappet on the left side, and a larger on the right, folded to form a respiratory siphon; gill comb-like, single; tongue short; teeth single, oval, slightly hooked and denticulated; uncini 3, oblong, denticulated. The paludinæ are viviparous; the shells of the young are ornamented with spiral rows of epidermal cirri.

Distr., $60 \mathrm{sp}$. Rivers and lakes throughout the N. hemisphere; Black sea, Caspian.

Fossil, 50 sp. Weald-. Brit., \&c.

Sub-genus. Bithinia (Prideaux), Gray. B. tentaculata, Pl. IX., fig. 27. Shell small ; operc. shelly. Animal oviparous; with only one neck-lappet, on the right side. The bithiniæ oviposit on stones and aquatic plants; the female lays from 30 to 70 eggs in a band of three rows, cleaning the surface as she proceeds; the young are hatched in three or four weeks, and attain their full growth in the second year (Bouchard).

Ampullaria, Lam. Apple-snail, or idol-shell.

Etym., ampulla, a globular flask.

Ex., A. globosa, Pl. IX., fig. 30. Syn., pachylabra, Sw.

Shell globular, with a small spire, and a large ventricose body-whirl peristome thickened and slightly reflected. Operc. shelly. 
Animal with a long incurrent siphon, formed by the left neck-lappet; left gill developed, but much smaller than the right*; muzzle produced into

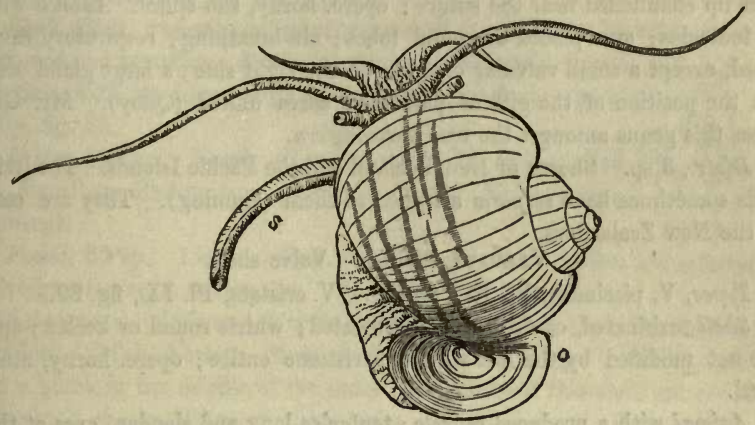

Fig. 84.†

two long tentacular processes; tentacles extremely elongated, slender. Inhabits lakes and rivers throughout the warmer parts of the world, retiring deep into the mud in the dry season, and capable of surviving a drought, or removal from the water for many years. In the lake Mareotis, and at the mouth of the Indus, ampullarix are abundant, mixed with marine shells. Their eggs are large, inclosed in capsules, and aggregated in globular masses.

Distr., 50 sp. S. America, West Indies, Africa, India.

Sub-genera. Pomus, Humph. A. ampullacea. Operc. horny.

Marisu, Gray (ceratodes, Guilding). A. cornu-arietis. Pl. IX., fig. 31. Operc. horny. Shell discoidal.

Asolene, D'Orb. A. platæ. Animal without a respiratory siphon; operc. shelly. Distr., S. America.

Lanistes, Montf. A. bolteniana, L., Pl. IX., fig. 32. Shell reversed, umbilicated, peristome thin; operc. horny. Distr., W. Africa, Zanzibar, Nile.

Meladomus, Sw. Paludina olivacea, Sby. Shell reversed, imperforate; peristome thin; operc. horny.

\section{? AMPHIBOLA, Schumacher.}

Syn., ampullacera, Quoy. Thallicera, Sw.

* The ampullaria is said to have a pulmonic sac in addition to its gills (Gray, Owen), but we have not met with specimens sufficiently well preserved to exhibit it.

would be very desirable to examine the amp. cornu-arietis, in which, probably, the gills are symmetrical, as in the cephalopods.

† Fig. 84. Ampullaria canaliculata, Lam. (from D'Orb.) South America. The branchial siphon $(s)$ is seen projecting from the left side; 0 , operculum 
Type, A. australis, Pl. IX., fig. 33.

Shell globular, with an uneven, battered, surface; columella fissured; outer lip channelled near the suture; operc. horny, sub-spiral. Animal without tentacles; eyes placed on round lobes; air-breathing; respiratory cavity closed, except a small valvular opening on the right side; a large gland occupies the position of the gill of paludina; sexes united (Quoy). Mr. Gray places this genus amongst the true pulmonifera.

Distr., 3 sp. Shores of New Zealand and the Pacific Islands. The living shells sometimes have serpula attached to them (Cuming). They are eaten by the New Zealanders.

Varvata, Müller. Valve-shell.

Types, V. piscinalis, Pl. IX., fig. 28. V. cristata, Pl. IX., fig. 29.

Shell turbinated, or discoidal, umbilicated; whirls round or keeled; aperture not modified by the last whirl; peristome entire; operc. horny, multispiral.

Animal with a produced muzzle; tentacles long and slender, eyes at their outer bases; foot bi-lobed in front; branchial plume long, pectinated, partially exserted on the right side, when the animal is walking. Lingual teeth broad; uncini 3, lanceolate; all hooked and denticulated.

Distr., $6 \mathrm{sp.}$ Brit., N. America.

Fossil, 19 sp. Wealden-. Brit., Belgium, \&c.

FAMILY VIII. NERITIDA.

Shell thick, semi-globose; spire very small; cavity simple, from the absorption of the internal portions of the whirls ; aperture semi-lunate; columellar side expanded and flattened; outer lip acute. Operculum shelly, subspiral, articulated.

At each end of the columella there is an oblong muscular impression, connected on the outer side by a ridge, on which the operculum rests; within this ridge the inner layers of the shell are absorbed.

Animal with a broad, short muzzle, and long slender tentacles; eyes on prominent pedicels, at the outer bases of the tentacles; foot oblong, triangular. Lingual dentition similar to the turbinida. Teeth 7; uncini very numerous.

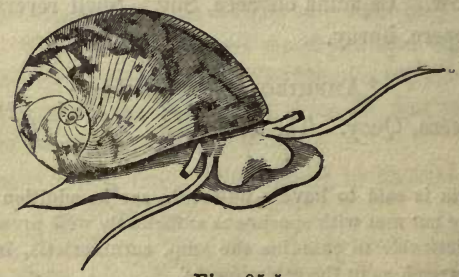

Fig. 85.*

* Fig. 85. Nerita polita, L. (from Quoy and Gaimard) New Ireland. 


\section{Nerita, L. Nerite.}

Etym. Nerites, a sea-snail, from nereîs.

Type, N. ustulata, Pl. IX., fig. 35 .

Shell thick, smooth or spirally grooved; epidermis horny; outer lip thickened and sometimes denticulated within; columella broad and flat, with its inner edge straight and toothed; operc. shelly, fig. 86.

Distr., 116 sp. Nearly all warm seas. W. Indies, Red Sea, Zanzibar, Philippines, Australia, Pacific, W. America, (Cuming).

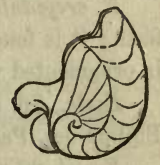

Fig. $86 . *$

Fossil, 60 sp. Lias-. Brit. \&c. The palæozoic nerites are referred by D'Orbigny to turbo, natica, \&c. N. haliotis is a pileopsis.

Sub-genera. Neritoma, Morris, 1849. N. sinuosa, Sby. Portland stone, Swindon. (Mus., Lowe). Shell ventricose, thick; lapex eroded; aperture with a notch in the middle of the outer lip. Casts of this shell are common, and exhibit the condition of the interior characteristic of all the nerites; it was probably fresh-water.

Neritopsis, Grateloup. N. radula, Pl. VIII., fig. 9. Shell like nerita; inner lip with a single notch in the centre.

Distr., 1 sp. Pacific. Fossil, 20 sp. Trias ? Brit., France, \&c.

Velates, Montf. N. perversa, Gm. Pl. IX., fig. 36. Inner lip very thick and callous; outer lip prolonged behind, and partially enveloping the spire.

\section{Pileolus, (Cookson) J. Sowerby.}

Etym., pileolus, a little cap.

Type, P. plicatus, Pl. IX., fig. 37, 38.

Shell limpet-like above, with a sub-central apex; concave beneath, with a small semi-lunar aperture, and a columellar disk, surrounded by a broad continuous peristome.

Distr., marine; only known as fossils of the Bath oolite, Ancliffe, and Minchinhampton, $3 \mathrm{sp} . \quad P$. neritoides is a neritina.

\section{Neritina, Lam. Fresh-water nerite.}

Examples, N. zebra, Pl. IX., fig. 39. N. crepidularia, Pl. IX., fig. 40.

Shell rather thick at the aperture, but extensively absorbed inside; outer lip acute; inner straight denticulated; operc. shelly, with a flexible border; slightly toothed on its straight edge.

Animal like nerita ; lingual teeth;-median, minute; laterals 3,1 large, sub-triangular, 2, 3, minute; uncini about 60 , first very large, hooked, denticulated; the rest equal, narrow, hooked, denticulated.

The neritinæ are small globular shells, ornamented with a great variety of black or purple bands and spots, covered with a polished horny epidermis.

* Fig. 86. Operculum of N. peloronta. W. Indies. 
They are mostly confined to the fresh waters of warm regions. One sp. (N fluviatilis) is found in Brit. rivers, and in the brackish water of the Baltic Another extends its range into the brackish waters of the N. American rivers And the West Indian $N$. viridis and meleagris, are found in the sea.

$N$. crepidularia has a continuous peristome, and approaches navicella in form; it is found in the brackish waters of India. N. corona (Madagascar is ornamented with a series of long tubular spines.

Distr., 76 sp. W. Indies, Norway, Brit., Black Sea, Caspian, India Philippines, Pacific, W. America.

Fossil, 20 sp. Eocene-. Brit., France. \&c.

\section{Navicella, Lam.}

Etym., navicella, a small boat. Type, N. porcellana. Pl. IX., fig. 41.

Shell obloug, smooth, limpet-like; with a posterior, sub-marginal apex aperture as large as the shell, with a small columellar shelf, and elongate lateral muscular scars ; operculum very small, shelly.

Distr., 18 sp. India, Mauritius, Moluccas, Australia, Pacific.

\section{FAMILY IX., TURBINIDE.}

Shell spiral, turbinated or pyramidal, nacreous inside; operculum calca rious and pauci-spiral, or horny and multi-spiral.

Animal with a short muzzle; eyes pedunculated at the outer bases of th long and slender tentacles; head and sides ornamented with fringed lobes an tentacular filaments (cirri); branchial plume single; lingual ribbon long an linear, chiefly contained in the visceral cavity; median teeth broad; latera? 5, denticulated; uncini very numerous (sometimes nearly 100), slender, wit) hooked points (Fig. 15, A.).

Marine, feeding on sea-weeds (alge).

The shells of nearly all the turbinidæ are brilliantly pearly, when th epidermis and outer layer of shell are removed; many of them are used in th state for ornamental purposes.

Turbo, L. Top-shell.

Etym., turbo, a whipping-top.

Syn., batillus, marmorostoma, callopoma, \&c. (Gray).

Type, T. marmoratus. Pl. X., fig. 2.

Shell turbinated, solid; whirls convex, often grooved or tuberculatec aperture large, rounded, slightly produced in front; operculum shelly ar solid, callous outside, and smooth, or variously grooved and mammillate internally horny and pauci-spiral. In. T. sarmaticus the extcrior of the ope culum is botryoidal, like some of the tufaceous deposits of petrifying wells.

Animal with pectinated head-lobes. 
Distr., 60 sp. Tropical seas, W. Indies, Medit., Cape, India, China, Anstralia, New Zealand, Pacific, Peru.

Fossil, 360 sp. (including litorina) L. Silurian-. Universal.

Phasianelia, Lam. Pheasant-shell.

Syn., eutropia (Humphr.) Gray. Tricolea, Risso.

Type, P. australis. Pl. X., fig. 3.

Shell elongated, polished, richly coloured; whirls, convex; aperture oval, not pearly; inner lip callous, outer thin; operc. shelly, callous outside, subspiral inside.

Animal with long ciliated tentacles; head-lobes pectinated, wanting in the minute sp.; neck-lobes fringed; sides ornamented with 3 cirri; branchial plume long, partly free; foot rounded in front, pointed behind; its sides moved alternately in walking; lingual teeth even-edged; laterals 5, hooked, denticulated; uncini about 70, gradually diminishing outwards, hooked and denticulated.

Distr., 25 sp. Australia, large sp. India, Philippines ; small sp. Medit., Brit., W. Indies, very small sp.

Fossil, $70 \mathrm{sp}$. Devonian ?-. Europe.

The similarity of the existing Australian fauna, to that of the European oolites, strengthens the probability that some, at least, of these fossil shells are rightly referred to Phasianella.

\section{IMPERATOR, Montf.}

Type, I, imperialis, Pl. 10, fig. 4. Syn., calcar.

Shell trochiform, thick, with a flat or concave base; whirls keeled or stellated; aperture angulated outside, brilliantly pearly; operc. shelly.

Distr., 20 sp. ? S. Africa, India, Australia, New Zealand.

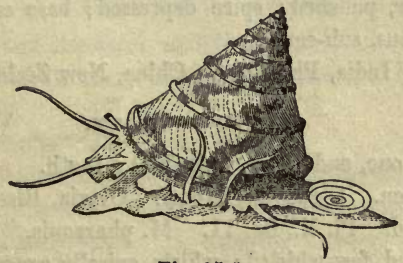

Fig. $87 . *$

Trochus, L.

Etym., trochus, a hoop.

Syn., cardinalia, tegula, and livona, Gray. Infundibulum, Montf. Chlorostoma, Sw. Trochiscus, Sby. Monilea, Sw.

Types, T. niloticus. Pl. X., fig. 5. T. zizyphinus. Fig. 87.

* Fig. 87. Trochus zizyphinus, L., Pegwell Bay, Kent. 
Shell pyramidal, with nearly a flat base ; whirls numerous, flat, variously striated; aperture oblique, rhombic, pearly inside; columella twisted, slightly truncated; outer lip thin; operculum horny, multi-spiral. Fig. 88 (T. pica).

Animal with 2 small or obsolete head-lobes between the tentacles; neck lappets large : sides ornamented with lobes, and $3-5$ cirri ; gill very long, linear; lingual teeth 11 , denticulated; uncini-90, diminishing outwards.

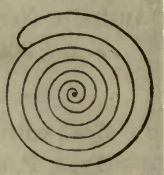

Fig. 88 .

Distr., $150 \mathrm{sp}$. World-wide. Low-water to 15 fathoms; the smaller species range nearly to 100 fathoms.

Fossil, 360 sp. Devonian-. Europe, N. America, Chile.

Sub-genera. Pyramis, Chemn., Tr. obeliscus, Pl. X., fig. 6, columella contorted, forming a slight canal.

Gibbula, Leach. Tr. magus, Brit. Shell depressed, widely umbilicated; whirls tumid. Head-lobes largely developed; lateral cirri 3.

Margarita, Leach. Tr. helicinus. Pl. X., fig. 7. Shell thin; cirri 5 on each side. Distr., 17 sp. Greenland, Brit., Falkland Islands. Near lowwater, under stones and sea-weed.

Elenchus, Humph. (= Canthiridus, Montf.) E. iris. Pl. X., fig. 8. Smooth, thin, imperforate, with a prominent base. Australia, N. Zealand. $F$. iris scarcely differs in form from Tr. zizyphinus; $E$. badius is like a pearly phasianella; and $E$. varians (bankivia, Menke) would be called a chemnitzia, if fossilized. Pl. X., fig. 9.

\section{RoTELLA, Lamarck.}

Etym., diminutive of rota, a wheel. (Syn., Helicina, Gray !)

Type, R. vestiaria. Pl. X., fig. 10.

Shell, lenticular, polished; spire depressed; base callous; lingual teeth 13 ; uncini numerous, sub-equal.

Distr., 10 sp. India, Philippines, China, New Zealand.

\section{Monodonta, Lam.}

Etym., monos, one, and odous, (odontos) a tooth.

Syn., labio, Oken. Clanculus, Montf. Otavia, Risso.

Types, M. labeo. Pl. X., fig. 11. M. pharaonis. Pl. X., fig. 12.

Shell, turbinated, few.whirled; whirls spirally grooved and granulated lip thickened internally, and grooved; columella toothed, more or less prominently and irregularly; operc. horny, many-whirled.

Distr., 10 sp ? W. Africa, Red Sea, India, Australia.

Fossil, (included with trochus) Devonian-. Eifel.

Delphinula (Roissy), Lam.

Etym., diminutive of delphinus, a dolphin. (= Cyclostoma, Gray !) 
Type, D. laciniata. Pl. X., fig. 13. (= T. delphinus, L.)

Shell orbicular, depressed; whirls few, angulated, rugose, or spiny ; aperture round, pearly; peristome continuous ; umbilicus open; operculum horny, many-whirled. On reefs, at low-water.

Animal without head-lobes; sides lobed and cirrated.

Distr., 20 sp. Red Sea, India, Philippines, China, Australia.

Fossil, 30 sp. ? Trias?-Miocene-. Europe.

Sub-genera. Liotia, Gray. L. gervillii. Pl. X., fig. 14. Aperture pearly, with a regular, expanded border. Operc. multi-spiral, calcarious. Distr., 6 sp. Cape, India, Philippines, Australia. Fossil, Eocene-. Brit., France.

Collonia, Gray, 1850. C. marginata. Pl. X., fig. 16. Peristome simple. Operc. calcarious, with a spiral rib on the outer side. Distr., Africa. Fossil, Eocene-. Paris.

Cyclostrema, Marryat. C. cancellata, Pl. X., fig. 15. Shell nearly discoidal, cancellated, not pearly; aperture round, simple; umbilicus wide. Operc. spiral, calcarious. Distr., 12 sp. Cape, India, Philippines, Australia, Peru. In 5-17 fathoms. Serpularia, Rœmer, has the whirls smooth and dis-united. Eocene, Paris.

ADEorbis, Searles Wood.

Type, A. sub-carinatus. Pl. X., fig. 17.

Shell minute, not nacreous, depressed, few-whirled, deeply umbilicated; peristome entire, nearly continuous, sinuated in its inner side, and slightly so externally. Operc. shelly, multi-spiral.

Distr., W. Indies-China. Low-water to 60 fathoms.

Fossil, 5 sp. Miocene-. Brit.

Euomphalus, Sowerby.

Etym., eu, wide, and omphalos, umbilicus.

Syn., schizostoma, Bronn. Macturea, Leseuer. Ophileta, Vanuxem. Platyschisma, McCoy.

Type, E. pentagonalis. Pl. X., fig. 18.

Shell depressed or discoidal; whirls angular or coronated; aperture polygonal; umbilicus very large. Operc. shelly, round, multi-spiral (Salter).

Fossil, $\mathrm{S0}$ sp., L. sil.-Trias. N. America, Europe, Australia.

Sub-genus. Phanerotinus, J. Sby. 1840, E. cristatus, Phil. Carb. limestone. Brit. Shell discoidal; whirls separate; outer margin sometimes foliaceous.

\section{Stomatella, Lam.}

Etym., diminutive of stoma, the aperture.

Type, S. imbricata. PI. X., fig. 19.

Shell ear-shaped, regular; spire small; aperture oblong, very large and 
oblique, nacreous; lip thin, even-edged ; operc. circular, horny, multi-spiral. On reefs and under stones at low-water.

Distr., 20 sp. Cape, India, N. Australia, China, Japan, Philippines.

Sub-genus? Gena, Gray. Spire minute, marginal; no operculum. 16 sp. Red Sea, India, Seychelles, Swan River, Philippines (Adams).

BRoDeripia, Gray.

Etym., named in honour of W. J. Broderip, Esq., the distinguished conchologist.

Type, B. rosea. Pl. X., fig. 20.

Shell minute, limpet-shaped, with a posterior sub-marginal apex; aperture oval, as large as the shell, brilliantly nacreous.

Distr., 3 sp. Philippines; Grimwood's Island, S. Seas (Cuming).

\section{FAMILY X. HaLIOTIDE.}

Shell spiral, ear-shaped or trochiform; aperture large, nacreous; outer lip notched or perforated. No operculum.

Animal with a short muzzle and subulate tentacles; eyes on pedicels at the outer bases of the tentacles; branchial plumes 2; mantle-margin with a posterior (anal) fold or siphon, occupying the slit or perforation in the shell; operc. lobe rudimentary; lingual dentition similar to trochus.

In addition to the true haliotids, we have retained in this group such of the trochi-form shells as have a notched or perforated aperture.

\section{HaLiotis, L. Ear-shell.}

Etym., halios, marine, and ous (otos) an ear.

Type, H. tuberculata, Pl. X., fig. 21.

Shell ear-shaped, with a small flat spire; aperture very wide, iridescent; exterior striated, dull; outer angle perforated by a series of holes, those of the spire progressively closed. Muscular impresssion horse-shoe shaped, the left branch greatly dilated in front. In $H$. tricostalis (padollus, Montf.) the shell is furrowed parallel with the line of perforations.

Animal with fimbriated head-lobes; side-lobes fimbriated and cirrated; foot very large, rounded. Lingual teeth;-median small; laterals single, beam-like; uncini about 70 , with denticulated hooks, the first 4 very large.

The haliotis abounds on the shores of the Channel Islands, where it is called the ormer, and is cooked after being well beaten to make it tender. (Hanley); it is also eaten in Japan. It is said to adhere very firmly to the rocks, with its large foot, like the limpet. The shell is much used for inlaying, and other ornamental purposes.

Distr., 75 sp. Brit., Canaries, Cape, India, China, Australia, New Zealand, Pacific, California.

Fossil, 4 sp. Miocene- Malta, \&c.

Sub-genús? Deridobranchus, Ehrenberg, D. argus, Red Sea. Shell 
large and thick, like haliotis, but entirely covered by the thick, hard, plaited mantle of the animal.

\section{Stomatia (Helblin), Lamarck.}

Etym., stoma, the aperture.

Type, S. phymotis, Pl. X., fig. 22.

Shell like haliotis, but without perforations, their place being occupied by a simple furrow; surface rugose, spirally ridged; spire small, prominent aperture large, oblong, outer margin irregular.

Distr., 12 sp. Java, Philippines, Torres Straits, Pacific. Under stones at low water (Cuming).

Fossil. M. D'Orbigny refers to this genus $18 \mathrm{sp}$, ranging from the L. Silurian to the chalk, N. America, Europe.

\section{Scissurella, D’Orb.}

Etym., diminutive of scissus, slit.

Type, S. crispata, Pl. X., fig. 23. Syn., anatomus, Montf.

Shell minute, thin, not pearly; body-whirl large; spire small; surface striated; aperture rounded, with a slit in the margin of the outer lip. Operculate.

Distr., $5 \mathrm{sp.}$ Norway, Brit., Medit. In 7 fathoms water off the Orkneys, and in deep water east of the Zetland Isles.

Fossil, 4 sp. Miocene-. Brit., Sicily.

Pleurotomaria, Defrance.

Etym., pleura, side, and tome, notch.

Type, P. anglica, Pl. X., fig. 24.

Shell, trochiform, solid, few-whirled, with the surface variously ornamented; aperture sub-quadrate, with a deep slit in its outer margin. The part of the slit which has been progressively filled up, forms a band round the whirls.

Fossil, 400 sp. Lower silurian-chalk. N. America, Europe, Australia. Specimens from clay strata retain their nacreous inner layers, those from the chalk and limestones have lost them, or they are replaced by crystalline spar. Pleurotomariæ with wavy bands of colour have been obtained in the carb. limestone of Lancashire. In this extensire group there are some species which rival the living turbines in magnitude and solidity, whilst others are as frail as ianthina.

Sub-genus. Scalites, Conrad (= raphistoma, Hall.) E.g., S. angulatus and stamineus. L. silurian, New York. Shell thin; whirls angular, flat above (tabulated), $8 \mathrm{sp.} \quad$ L. silurian-carb. Poly-tremaria, I'Orb., is founded on P. catenata, Koninck, in which the margins of the slit are wavy, converting it into a series of perforations.

Murchisonia, D'Archiac.

Etym., named in honour of Sir Roderick I. Murchison.

Type, M. bilineata. Pl. X., fig. 25. 
Shell elongated, many-whirled; whirls variously sculptured, and zoned like pleurotomaria; aperture slightly channelled in front; outer lip deeply notched.

The murchisoniæ are characteristic fossils of the palæozoic rocks; they have been compared to elongated pleurotomaria, or to cerithia with notched apertures; the first suggestion is most probably correct.

Fossil, 50 sp. L. silurian-Permian. N. America, Europe.

\section{Trochotoma, Lycett.}

Etym., trochus, and tome, a notch.

Syn., ditremaria, D'Orb.

Type, T. conuloides. Pl. X., fig. 26.

Shell trochiform, slightly concave beneath; whirls flat, spirally striated, rounded at the outer angles; lip with a single perforation near the margin.

Fossil, 10 sp. Lias-Coral Rag. Brit., France, \&c.

? Cirrus, Sowerby.

Etym., cirrus, a curl.

Type, C. nodosus, Sby. Min. Con. t. 141 and 219.

Shell sinistral, trochiform, base level; last whirl enlarging rather more rapidly, somewhat irregular.

Fossil, 2 sp. Inf. oolite, Bath oolite. Brit., France.

This genus was founded on a pleurotomaria, a euomphalus, and C. nodosus. (v. Min. Con.) It is still doubtful what species may be referred to it.

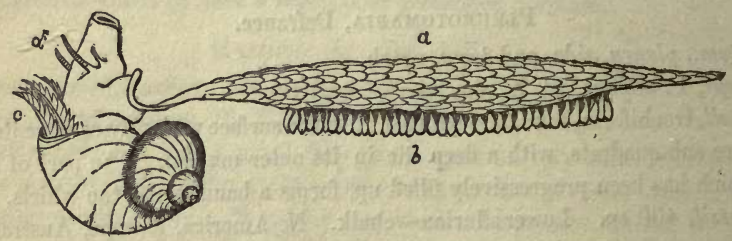

Fig. 89.*

IANTHINA, Lam. Violet-snail.

Etym., ianthina, violet-coloured.

Type, helix ianthina L. (I. fragilis, Lam.) Pl. X., fig. 27.

Shell thin, translucent, trochiform; nucleus minute, styliform, sinistral; whirls few, rather ventricose; aperture four-sided; columella tortuous; lip thin, notched at the outer angle. Base of the shell deep violet, spire nearly white.

Animal:-head large, muzzle-shaped, with a tentacle and eye-pedicel or.

* Fig. 89. Ianthina fragilis, Lam. (from Quoy and Gaimard). A tlantic. a raft, $b$ egg capsules, $c$ gills, $d$ tentacles and eye-stalks. 
each side, but no eyes; foot small, secreting a float composed of numerou cartilaginous air-vesicles, to the under surface of which the ovarian capsule are attached. Lingual ribbon, rachis unarmed; uncini numerous, simpl (like scalaria). Branchial plumes 2. Sexes separate.

\section{Distr., 6 sp. Atlantic, Coral sea.}

The ianthinæ, or oceanic-snails, are gregarious in the open sea, wher they are found in myriads, and are said to feed on the small blue acaleph (velella). They are frequently drifted to the southern and western Britis shores, especially when the wind continues long from the S.W.; in Swanse bay the animals have been found quite fresh. When handled they exude violet fluid from beneath the margin of the mantle. In rough weather the are driven about and their fioats broken, or detached, in which state they ar often met with. The capsules beneath the further end of the raft have bee observed to be empty, at a time when those in the middle contained youn with fully formed shells, and those near the animal were filled with egg They have no power of sinking and rising in the water. The raft, which much too large to be withdrawn into the shell, is an extreme modification the operculum.

\section{FAMILY XI. FIsSURELLIDÆ.}

Shell conical, limpet-shaped; apex recurved; nucleus spiral, often di: appearing in the course of growth; anterior margin notched, or apex perf rated; muscular impression horse-shoe shaped, open in front.

Animal with a well-developed head, a short muzzle, subulate tentacle and eyes on rudimentary pedicels at their outer bases; sides ornamented wit short cirri; branchial plumes 2, symmetrical; anal siphon occupying the ar terior notch or perforated summit of the shell. Lingual dentition similar trochus.*

\section{Fissurella, Lam. Key-hole limpet.}

Etym., diminutive of fissura, a slit.

Type, F. Listeri. PI. XI., fig. 1.

Shell oval, conical, depressed with the apex in front of the centre an perforated; surface radiated or cancellated; muscular impression with th points incurved.

In very young shells the apex is entire and sub-spiral; but as the perf ration increases in size it encroaches on the summit and gradually remov it. The key-hole limpets are locomotive ; they chiefly inhabit the laminaria zone, but range downwards to 50 fms.

Distr., 120 sp. America, Brit., S. Africa, India, China, Australia. California-Cape Horn.

* Fissurella is the best gasteropod for comparison with the bivalves ; its large gill placed one on each side, and its symmetrical shell, pierced with a median orifice $f$ the escape of the out-going branchial current, are unmistakeable indications of hom logies with the lamelli-branchiata. See p. 48. 
Fossil, 25 sp. Carb. ? oolites-. Brit., France.

Sub-genera. Pupillia, Gray. F. apertura, Born. (= hiantula, Lam.) Shell smooth, surrounded by a sharp white edge; perforation very large. Distr., S. Africa.

Fissurellidaa, D’Orb. F. hiatula, Lam. (=megatrema, D'Orb.) Shell cancellated; covered by the mantle of the animal. 3 sp. Cape, Tasmania.

(Macroschisma, Sw.) F. macroschisma. Pl. XI., fig. 2. Anal aperture close to the posterior margin of the shell. The animal is so much larger than its shell, as to be compared to the testacelle by Mr. Cuming. Distr., Philippines, Swan river.

Lucapina, Gray. F. elegans, Gray (=aperta, Sby.). Shell white, cancellated, margin crenulated; covered by the reflected mantle. 3 sp. California.

\section{Puncturelta, Lowe.}

Syn., cemoria, Leach. Diadora, Gray.

Type, P. noachina. Pl. XI., fig. 3.

Shell conical, elevated, with the apex recurved; perforation in front of the apex, with a raised border internally; surface cancellated.

Distr., 2 sp. Greenland, Boreal America, Norway, N. Brit., Tierra-delfuego. In 20-100 fathoms water.

Fossil, in the glacial formations of N. Brit.

\section{Rimula, Defrance.}

Etym., diminutive of rima, a fissure. (Syn., Rimularia.)

Recent type, R. Blainvillii. Pl. XI., fig. 4.

Shell thin and cancellated, with a perforation near the anterior margin.

Distr., several sp. found on sandy mud at low-water, or dredged in from 10-25 fms. Philippines (Cuming).

Fossil, 3 sp. Bath oolite-coral-rag. Brit., France.

Emarginula, Lam.

Etym., dimunitive of emarginata, notched.

Type, E. reticulata. Pl. XI., figs. 5, 6.

Shell oval, conical, elevated, with the apex recurved; surface cancellated; anterior margin notched, Muscular impression with recurved points. The nucleus (or shell of the fry) is spiral, and resembles scissurella. The anterior slit is very variable in extent. The animal of Emarginula (and also of puncturella) has an isolated cirrus on the back of the foot, perhaps representing the operculigerons lobe (Forbes). Lingual dentition; median teeth subquadrate; laterals 4, oblong, imbricated; uncini about 60 , the first large and thick, with a lobed hook, the rest linear, with serrulated hooks (Lovén).

Distr., 26 sp. W. Indies, Brit., Norway, Philippines, Australia. Range from low-water to 90 fathoms.

Fossil, 40 sp. Trias-. Brit., France. 
Sub-genus. Hemitoma, Sw. Type, E. octoradiata. (E. rugosa. PI. XI., figs. 7, 8.) Shell depressed; anterior margin slightly channelled.

ParMóphorus, Blainville. Duck's-bill limpet.

Etym., parme, a shield, and phoreus, a bearer.

Type, P. australis. P1. XI., fig. 9. Syn., Scutus, Montf.

Shell lengthened-oblong, depressed; apex posterior ; front margin arched Muscular impression horse-shoe shaped, elongated. The shell is smooth anc white, and permanently covered by the reflected borders of the mantle. The animal is black, and very large compared with the shell; its sides are fringe with short cirri, and its eyes sessile on the outer bases of thick tentacles; i is found in shallow-water, and walks freely (Cuming).

Distr., 10 sp. New Zealand, Australia, Philippines, Singapore, Red Sea Cape.

F'ossil, 3 sp. Eocene?-. Paris basin.

FAMILY XII. Calyptreide. Bonnet-limpets.

Shell limpet-like, with the apex more or less spiral; interior simple, o divided by a shelly-process, variously shaped, to which the adductor muscle are attached.

Animal with a distinct head; muzzle lengthened; eyes on the externa bases of the tentacles; branchial plume single. Lingual teeth single, uncini 3

The bonnet-limpets are found adhering to stones and shells; most of then appear never to quit the spot on which they first settle, as the margins c their shells become adapted to the surface beneath, whilst some wear awa the space beneath their foot, and others secrete a shelly base. Both thei form and colour depend on the situation in which they grow; those found $i$ the cavities of dead shells are nearly flat, or even concave above, and colour less. They are presumed to feed on the sea-weed growing round them, or o animacules; a calyptrae, which Professor Forbes kept in a glass, ate a sma sea slug (goniodoris) which was confined with it. Both calyptraea and pile opsis sometimes cover and hatch their spawn in front of their foot (Alder an Clarke).

Mr. Gray arranges the bonnet-limpets next after the vermetidæ; thei lingual dentition is like velutina.

Calyptrai, Lam. Cup-and-saucer limpet.

Etym., calyptra, a (lady's) cap.

Syn., lithedaphus, Owen.

Types, C. equestris. Pl. XI., fig. 10. C. Dillwynnii, fig. 11.

Shell conical; limpet-shaped; apex posterior, with a minute, spirs nucleus; margin irregular; interior with a half-cup shaped process on th posterior side, attached to the apex, and open in front. Surface rugose 0 cancellated. 
Animal with a broad muzzle; tentacles rather short; lanceolate; eyes on bulgings at the outer bases of the tentacles; mantle-margin simple, sides plain. Found under stones, between tide-marks, and in shallow water (Cuming).

Distr., 50 sp. W. Indies, Honduras, Brit., Medit., Africa, India, Philippines, China, Japan, New Zealand, Gallapagos, Chili,

Fossil, 30 sp. Carb? chalk-. Brit., France, \&c.

, Sub-genera. Crucibulum, Schum. (Dispotæa, Say., Calypeopsis, Less.) Ex. C. rudis, Pl. XI., fig. 12. Shell spinulose; internal cup entire; attached by one of its sides. Distr., W. America, Japan, W. Indies. Found on shells, with its base worn, or smoothed by a shelly deposit (Gray). Between this section and the next there are several intermediate forms.

Trochita, Schum. (Infundibulum, J. Sby., Galerus, Humph. Trochatella and Siphopatella, Lesson.) T. radians, Pl. XI., figs. 13, 14. (=Patella trochoides, Dillw.) T. sinensis, Pl. XI., fig. 15. Shell circular, more or less distinctly spiral; apex central; interior with a more or less complete subspiral partition. Distr., chiefly tropical, but ranges from Britain to New Zealand. T. prisca (McCoy) is found in the carb. limestone in Ireland; and several large species occur in the London clay and Paris basin. The recent C. sinensis - the "China-man's hat" of collectors-is found on the southern shores of England, and in the Mediterranean, in 5-10 fms. water (Forbes). Its lingual dentition is given by Lovén; - median teeth broad, hooked, denticulated; uncini 3 , the first hooked and serrated, 2, 3 claw-shaped, simple.

\section{Crepidula, Lam.}

Etym., crepidula, a small sandal.

Type, C. fornicata, Pl. XI., fig. 16. Syn., crypta, Humph.

Shell oval, limpet-like ; with a posterior, oblique marginal apex ; interior polished, with a shelly partition covering its posterior half.

The crepidalæ resemble the fresh-water navicellæ in form ; but the internal ledge which mimics the columella of the nerite, is here the basis of the adductor muscles.

They are sedentary on stones and shells, in shallow water, and are sometimes found adhering to one another in groups of many successive generations. The specimens or species which live inside empty spural shells are very thin, nearly flat, and colourless.

Distr., 40 sp. W. Indies, Honduras, Medit., W. Africa, Cape, India, Australia, W. America.

Fossil, 14 sp. Eocene-. France, N. America, Patagonia.

Pileopsis, Lam. Bonnet-limpet.

Etym., pileos, a cap, and opsis, like.

Syn., capulus, Montf. Brocchia, Bronn.

Type, P. hungaricus, P1. XI., fig. 17. P. militaris, Pl. XI., fig. 18. 
Shell conical ; apex posterior, spirally recurved; aperture rounded ; muscular impression horse-shoe shaped.

Animal with a fringed mantle-margin; lingual teeth like calyptraa.

P. hungaricus (the Hungarian-bonnet) is found on oysters, in 5 to 15 fms. water; more rarely as deep as $80 \mathrm{fms}$, and then very small. P. militaris is extremely like a velutina.

Distr., 7 sp. W. Indies, Norway, Brit., Medit., India, Australia, Califoruia.

Fossil, 20 sp. Lias-. Europe.

Sub-genus. Amathina, Gray. A. tricarinata, Pl. XI., fig. 19. Shell depressed, oblong; apex posterior, not spiral, with three strong ribs diverging from it to the anterior margin.

Platyceras, Conrad (acroculia, Phil.). P. vetustus. Carb., limestone. Brit.

Fossil, 20 sp. Devonian-Trias. America, Europe.

Hipponyx, Defrance.

Etym., hippos, a horse, and ony $x$, a hoof.

Type, H. cornucopia, Pl. XI., figs. 20, 21.

Shell thick, obliquely conical, apex posterior; base shelly, with a horseshoe-shaped impression, corresponding to that of the adductor muscle.

Distr., 10 sp. W. Indies. Persian Gulf, Philippines, Australia, Pacific, W. America.

Fossil, 10 sp. U. chalk-. Brit., France, N. America.

Sub-genus. Amalthea, Schum. A. conica. Like hipponyx, but forming no shelly base; surface of attachment worn and marked with a crescentshaped impression. Often occurs on living shells, such as the large turbines, and turbinellæ of the Eastern seas.

FAMILY XIII. PATellide. Limpets.

Shell conical, with the apex turned forwards ; muscular impression horseshoe-shaped, open in front.

Animal with a distinct head, furnished with tentacles, bearing eyes at their outer bases; foot as large as the margin of the shell; mantle plain or fringed. Respiratory organ in the form of one or two branchial plumes, lodged in a cervical cavity; or of a series of lamellæ surrounding the animal, between its foot and mantle. Mouth armed with horny jaws, and a long ribbon-like tongue, furnished with numerous teeth, each consisting of a pellucid base and an opaque hooked apex.

The order cyclo-branchiata of Cuvier included the chitors and the limpets, and was characterised by the circular arrangement of the branchiæ. At a comparatively recent period it was ascertained that some of the patellæ (acmaea) had a free, cervical gill; whilst the chitons exhibited too many peculiaritics to admit of being associated so closely with them. Professor 
Forbes has very happily suggested that the cyclo-branchiate gill of patella is, in reality, a single, long branchial plume, originating on the left side of the neck, coiled backwards round the foot, and attached throughout its length. This view is confirmed by the circumstance that the gill of the sea-weed limpets (nacella) does not form a complete circle, but ends without passing in front of the animal's head.

\section{Patella, L. Rock limpet.}

Etym., patella, a dish. Syn., helcion, Montf.

Ex., P. longicostata, PI. XI., fig. 22.

Shell oval, with a sub-central apex ; surface smooth, or ornamented with radiating striæ or ribs; margin even or spiny ; interior smooth.

Animal with a continuous series of branchial lamellæ; mantle-margin fringed; eyes sessile, externally, on the swollen bases of the tentacles; mouth notched below. Lingual teeth 6 , of which 4 are central, and 2 lateral; uncini 3.

The tongue of the common British limpet (P. vulgata) is rather longer than its shell; it has 160 rows of teeth, with 12 teeth in each row, or 1,920 in all (Forbes.) The limpets live on rocky coasts, between tide-marks, and are consequently left dry twice every day; they adhere very firmly, by atmospheric pressure (15lbs per square inch), and the difficulty of detaching them is increased by the form of the shell. On soft calcarious rocks, like the chalk of the coast of Thanet, they live in pits half an inch deep, probably formed by the carbonic acid disengaged in respiration; on hard limestones only the aged specimens are found to have worn the rock beneath, and the margin of their shell is often accommodated to the inequalities of the surrounding surface. These circumstances would seem to imply that the limpets are sedentary, and live on the sea-weed within reach of their tongues, or else that they return to the same spot to roost. On the coast of Northumberland we have seen them sheltering themselves in the crevices of rocks, whose broad surfaces, overgrown with nullipores, were covered with irregular tracks, apparently rasped by the limpets in their nocturnal excursions.*

The limpet is much used by fishermen for bait; on the coast of Berwick. shire nearly 12,000,000 have been collected yearly, until their numbers are so decreased that collecting them has become tedious (Dr. Johnston). In the north of Ireland they are used for human food, especially in seasons of scarcity; many tons weight are collected annually near the town of Larne alone (Pattison).

On the western coast of S. America there is a limpet which attains the diameter of a foot, and is used by the natives as a basin (Cuming).

* If limpets are placed in stale water, or little pools exposed to the hot sun, they creep out more quickly than one would expect; the tracks they leave are very peculiar and not likely to be mistaken when once seen. 
Distr., 100 sp. Brit., Norway, \&c. World-wide.

Fossil, above $100 \mathrm{sp}$. of patellidæ, including acmaa, L. silurian-. N. America, Europe.

Sub-genera. Nacella, Schum. (= patina, Leach.) Example, P. pellucida. Pl. XI., fig. 23. Shell thin; apex nearly marginal. Animal with the mouth entire below. Branchiæ not continued in front of the head. Found on the fronds and stalks of sea-weeds. Brit., Cape, Cape Horn.

Scutellina, Gray. S. crenulata. Shell with a broad margin, internally. 7 sp. Red Sea-Philippines-Pacific-Panama (Cuming).

Metoptoma, Phillips. M. pileus $\mathrm{Ph}$. Shell limpet-like, side beneath the apex truncated. Resembling the posterior valve of a chiton. $7 \mathrm{sp}$. Carb. limestone. Brit.

\section{ACMæA, Eschscholtz.}

Etym., acme, a point.

Syn., tectura, M. Edw. Lottia and scurria, Gray. Patelloida, Quoy.

Type, A. testudinalis. Pl. XI., fig. 24.

Shell like patella. Animal with a single pectinated gill; lodged in a cervical cavity, and exserted from the right side of the neck when the creature walks. Lingual teeth 3 on each side of the median line. Low-water to $30 \mathrm{fms}$. (Forbes.)

Distr., 20 sp. Norway, Brit., Australia, Pacific, W. America.

Sub-genera. Lepeta, Gray (= pro-pilidium, Forbes). Patella cæca, Müll. Shell minute, apex posterior. Animal blind. Brit. 30-90 fms.

Pilidium, Forbes. P. fulva, Müll. Brit. 20-80 fathoms water. Shell small, apex anterior. Animal blind; gills 2, not projecting; mantle evenedged. Both lepeta and pilidium have large single median teeth, with trilobed hooks; and 2 hooked uncini on each side.

\section{Gadinta (Adanson), Gray.}

Type, G. peruviana. Plate XI., fig. 26. Syn., mouretia, Sby.

Shell conical; muscular impression horse-shoe shaped, the right side shortest, terminating at the siphonal groove.

Animal with a single cervical gill; tentacles expanded, funnel-shaped.

Distr., $8 \mathrm{sp.}$ Medit., Red Sea, Africa, Peru.

Fossil, 1 sp. Sicily.

\section{? Siphonaria, Blainville.}

Type, S. sipho. Pl. XI., fig. 25.

Shell like patella; apex sub-central, posterior; muscular impression horse-shoe shaped, divided on the right side by a deep siphonal groove, which produces a slight projection on the margin. 
Animal with a broad head, destitute of tentacles ; eyes sessile on prominent rounded lobes; gill ? single. The siphonariæ are found between tidemarks, like limpets; Mr. Gray places them with the pulmonifera, between auriculidæ and cyclostomidæ.

Distr., 30 sp. Cape, India, Philippines, Australia, New Zealand, Pacific, Gallapagos, Peru, Cape Horn (Cuming).

Fossil, 3 sp. Miocene -.

\section{FAMILY XIV., Dentaliade. Tooth-shells.}

\section{Dentalium, L.}

Type, D. elephantinum. Pl. XI., fig. 27.

Shell tubular, symmetrical, curved, open at each end, attenuated pos. teriorly; surface smooth or longitudinally striated; apertnre circular, not constricted.*

Animal attached to its shell near the posterior, anal orifice; head rudidimentary, eyes 0 , tentacles 0 ; oral orifice fringed; foot pointed, conical, with symmetrical side-lobes, and an attenuated base, in which is a hollow communicating with the stomach. Branchia 2, symmetrical, posterior to the heart; blood red (Clarke); sexes united? Lingual ribbon wide, ovate rachis 1-toothed; uncini single, flanked by single unarmed plates.

The tooth-shells are animal-feeders, devouring foraminifera and minute bivalves; they are found on sand, or mud, in which they often bury them. selves. The British sp. range from $10-100 \mathrm{fms}$. (Forbes.)

Distr., 30 sp. W. Indies, Norway, Brit., Medit., India.

Fossil, 70 sp. Devonian-. Europe, Chile.

\section{FAMILY XV., ChITONIDA.}

\section{Chiton, L.}

Etym., chiton, a coat of mail.

$E x$., C. squamosus, spinosus, fascicularis, fasciatus. P1.XI., figs. 28-31

Shell composed of 8 transverse imbricating plates, lodged in a coriaceou mantle, which forms an expanded margin round the body. The first sever plates have posterior apices; the eighth has its apex nearly in front. Thi six middle plates are each divided by lines of sculpturing into a dorsal an two lateral areas. All are inserted into the mantle of the animal by processe (apophyses) from their front margins. The posterior plate is considered ho mologous with the limpet-shell, by Mr. Gray; the other plates appear lik portions of its anterior slope, successively detached. The border of the mant is either bare, or covered with minute plates, hairs, or spines. 
Animal with a broad creeping disk like the limpet; proboscis armed with cartilaginous jaws, and a long linear tongue; lingual teeth 3 ; median small, laterals large, with dentated hooks; uncini 5 , trapezoidal, one of them erect and hooked. No eyes, or tentacles. Branchiæ forming a series of lamellæ between the foot and the mantle, round the posterior part of the body. The heart is central, and elongated like the dorsal vessel of the arnelides; the sexes are united; the re-productive organs are symmetrically repeated on each side, and have two orifices; the intestine is straight, and the anal orifice posterior and median.

Distr. More than 200 species are known; they occur in all climates throughout the world; most abundant on rocks at low-water, but frequently obtained by dredging in 10-25 fathoms water. Some of the small British species range as deep as 100 fms. (Forbes.) W. Indies, Europe, S. Africa, Australia, and New Zealand, California to Chiloë.

Fossil, 24 sp. Silurian-. Brit., Belgium, \&c.

Sub-genera.* Chiton, (Syn., lophurus, Poli. Radsia, callo-chiton, ischno-chiton, and lepto-chiton, Gray).

Ex., C. squamosus. Pl. XI., fig. 28. Border tessellated.

Distr. Brazil, W. Indies, Newfoundland, Greenland, Brit., Medit., Cape, Philippines, Australia, New Zealand, W. America.

Tonicia, Gray. C. elegans. Margin bare. Distr. Greenland, C. Horn, New Zealand, Valparaiso.

Acanthopleura, Guilding. C. spinosus. Pl. XI., fig. 29. Margin covercd with spines, or elongated scales. Syn. Schizo-chiton, corephium, plaxiphora, onycho-chiton, enoplo-chiton, Gray. Distr. W. Indies, C. Horn, Falklands, Africa, Philippines, Australia, New Zealand, Valparaiso.

Mopalia, Gray. C. Hindsii. Border hairy.'Distr., W. America, Falkland Islands.

Katharina, Gray, C. tunicatus. Mantle covering all but the centre of the plates. Distr. New Zealand, W. America.

Cryptochiton, Gray, "Saw-dust chiton.". C. amiculatus. Valves covered with scaly epidermis. Syn., cryptoconchus, Sw. Amicula, Gray. Distr., California, New Zealand.

Acanthochites, Leach. C. fascicularis. Pl. XI., fig. 30. Border ornamented with tufts of slender spines, opposite the plates. Distr., Brit., Medit. New Zealand.

Chitonellus, Lam. C. fasciatus, Quoy. PI. XI., fig. 31. Border velvety; exposed portion of the plates small, distant; apophyses close to-

* The sub-genera of Mr. Gray are founded on the form of the plates of insertion; they are described in detail in the proceedings of the Zoological Society. Dr. Middendorf employs the number of the branchial lamina for distinguishing the sections. 
gether. Distr., 10 sp. W. Indies, W. Africa, Philippines, Australia, $\mathrm{Pa}$ Panama. The chitonellæ are found in fissures of coral rock (Cuming).

Grypho-chiton, Gray. C. nervicanus.

Helminthochiton, Salter, 1847. H. Griffithii, Salter Geol. Journ. Plate sub-quadrate, not covered by the mantle; apophyses widely separated. Fossil. Silurian. Ireland. 

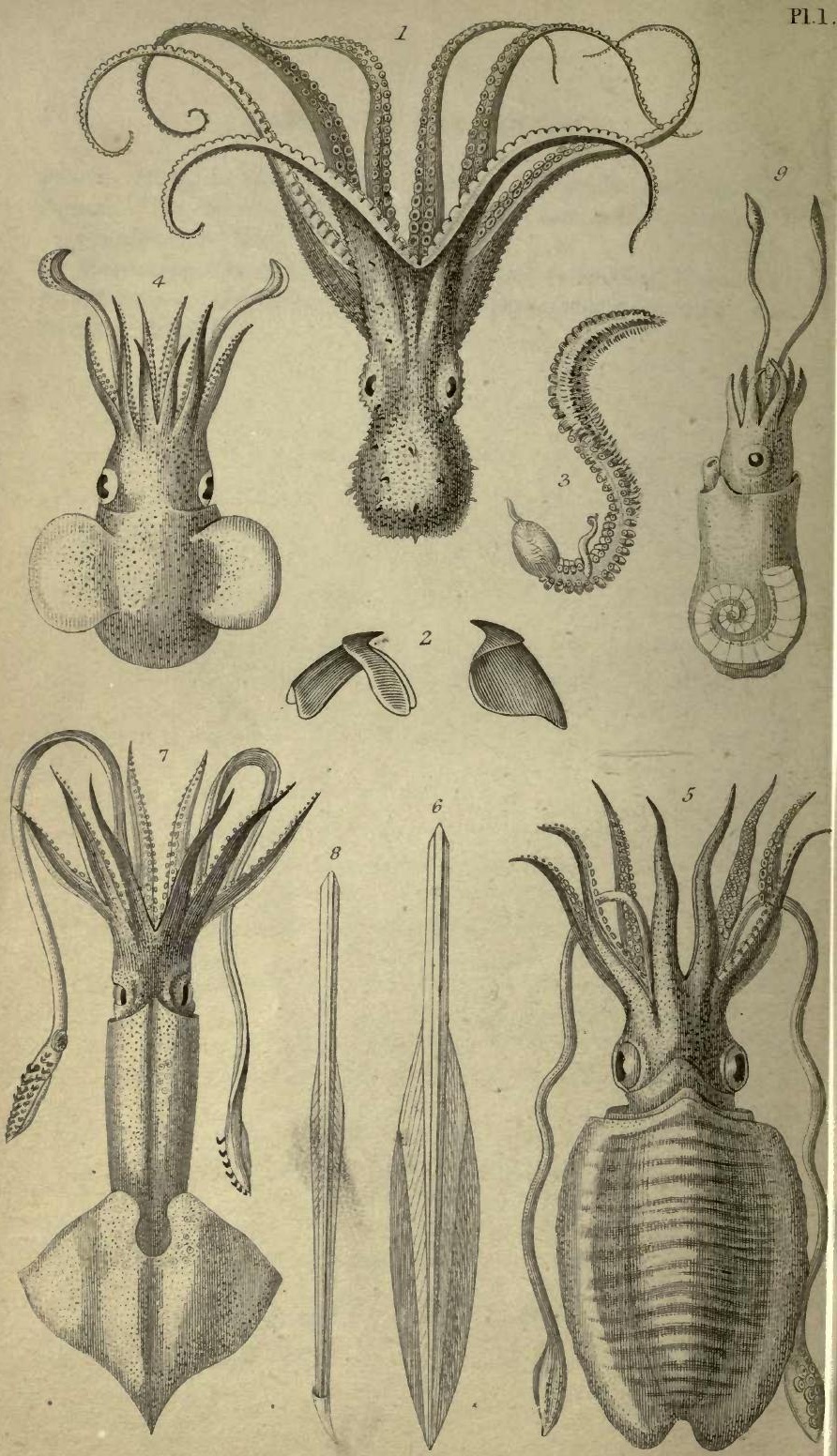


\section{EXPLANATION OF THE PLATES.}

The principal specimens figured were kindly communicated by Mrs. J. E. Gray, Mr. Hugh Cuming, Major W. E. Baker, Mr. Laidlay of Calcutta, Mr. Pickering, Sir Chas. Lyell, Mr. Sylvanus Hanley, Mr. James Tennant, and Mr. Lovell Reeve.

The fractions shew the number of times (or diameters) the figures are reduced, or magnified.

\section{PLATE I.}

Octopodida.

1. Octopus tuberculatus, Bl. $\frac{1}{5}$. Mediterranean ..................... 67

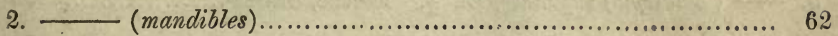

3. Tremoctopus violaceus, $\delta$. Chiaje. Messina ................65, 68

\section{Teuthida.}

4. Sepiola oceanica, Orb. Atlantic ................................ 71

6. Loligo vulgaris, Lam. (gladius). $\frac{1}{4}$. Britain ................. 69

7. Onychoteuthis Bartlingii, Le Sueur. $\frac{1}{4}$. Indian Ocean............ 72

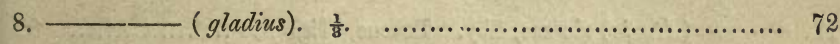

\section{Sepiada.}

5. Sepia officinalis, L. $\quad \frac{1}{6} . \quad$ Britain............................... 76

\section{Spirulida.}

9. Spirula lævis, Gray. $\frac{1}{2}$. New Zealand 
PLATE II.

Argonautida.

1. Argonauta hians, Solander, $\frac{1}{2}$. China

Teuthida.

8. Beloteuthis subcostata, Münst. $\frac{1}{4}$. U. Lias, Wurtemberg........... 70 Belemnitide.

Belemnites Puzosianus, Orb. $\frac{1}{5}$. Oxford Clay, Chippenham _.... 73

6. Belemnitella mucronata, Sby. $\frac{1}{4}$. U. Chalk, Norwich ............. 74

9. Conoteuthis Dupiniana, Orb. Neocomian, France ............ 76 Sepiada.

2. Sepia Orbigniana, Fér. $\frac{1}{2}$. Mediterranean...................... 76

3. - (Belosepia $)$ sepiö̈des, Bl. $\frac{1}{2}$. Eocene, Sussex ............. 76

4. Spirulirostra Bellardii, Orb. $\frac{4}{3}$. Miocene, Turin ................. 76

7. Beloptera belemnitoïdes, Bl. $\frac{2}{3}$. Eocene, Sussex ............... 76

Nautilida.

10. Nautilus radiatus, Sby. $\frac{1}{4}$. Neocomian, Kent .................... 83

11. - bidorsatus, Schl. (upper mandible = Rhyncholites hirundo, F. Biguet.) $\frac{2}{3}$. Muschelkalk, Bavaria................. 81

12. - (Aturia $)$ zic-zac, Sby. Eocene, Highgate ................. 86

16. Clymenia striata, Münst. Devonian, S. Petherwin ............... 87

\section{Orthoceratida.}

14. Orthoceras gigantum, Sby. (section.) $\frac{1}{24}$. Carb. limestone, Britain 88

15. Phragmoceras ventricosum, Stein. $\frac{1}{5}$. L. Ludlow-rock, Salop ..... 90

13. Gyroceras eifeliense, Arch. (section.) $\frac{1}{2}$. Devonian, Eifel........... 91 


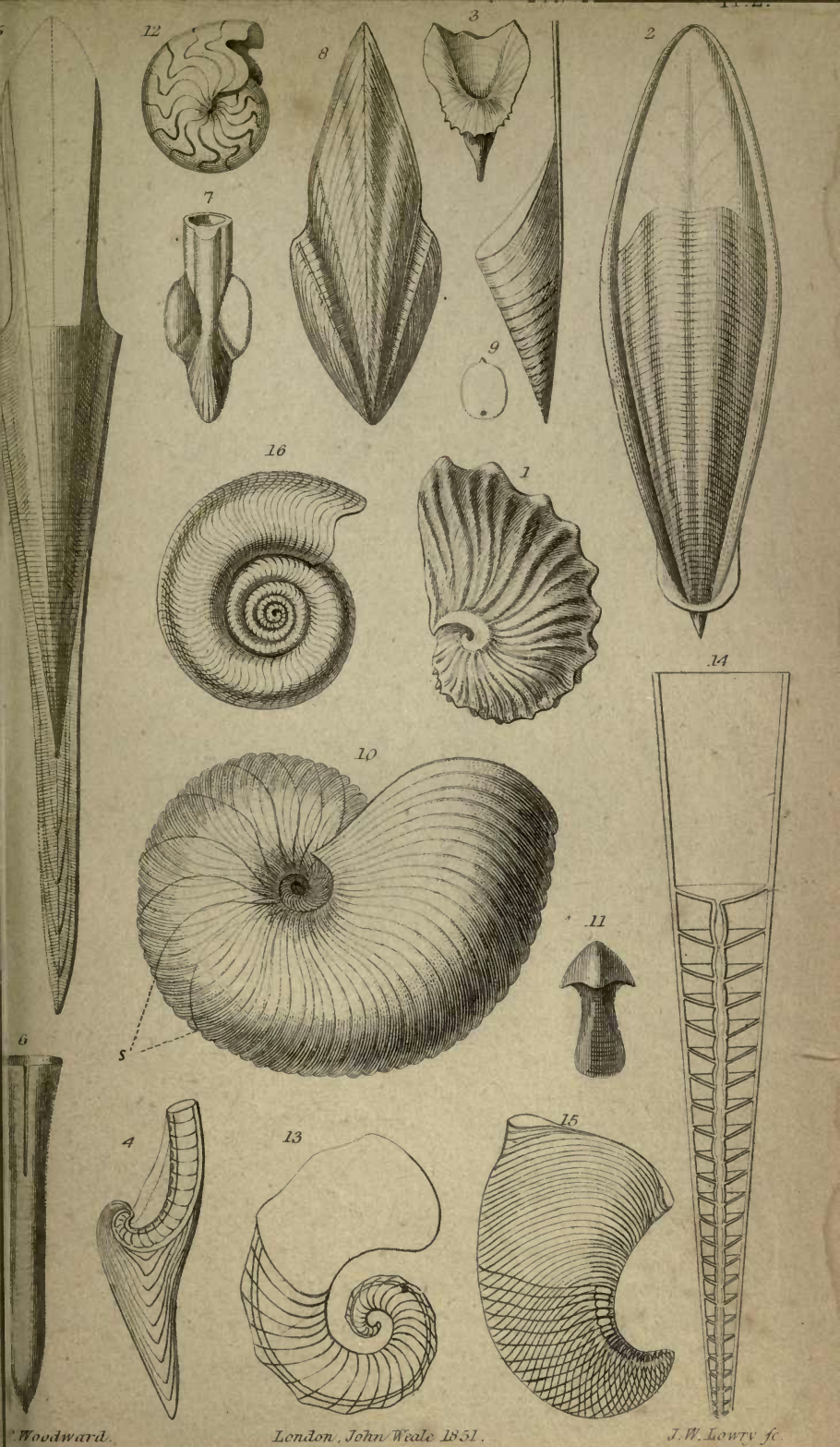





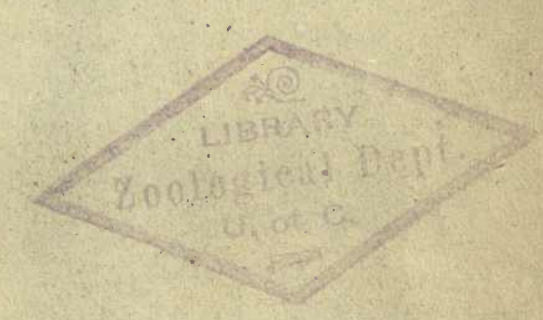



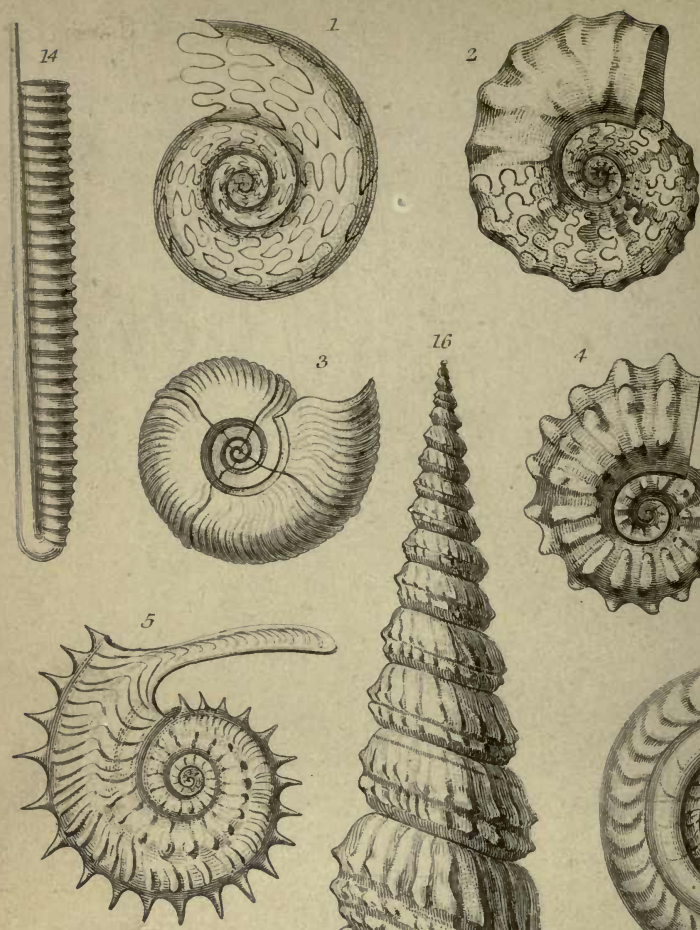

s

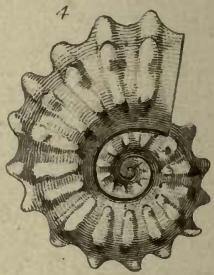

7

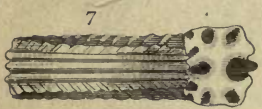

Ono
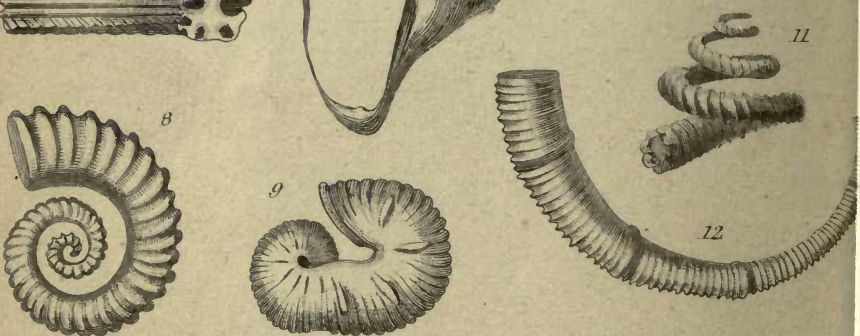

75

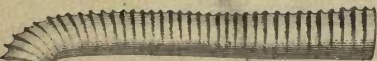
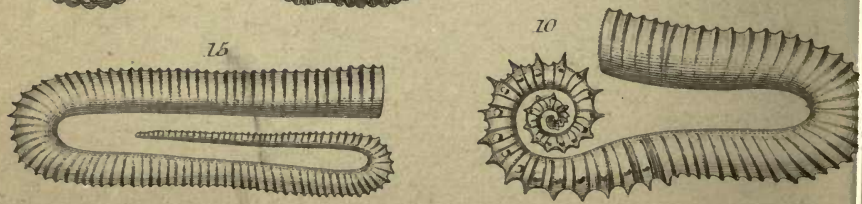
PLATE III.

\section{Ammonitida.}

1. Goniatites Henslowi, Sby. $\frac{1}{3}$. Carb. limestone, Isle of Man ..... 93

2. Ceratites nodosus, Brug. $\quad \frac{1}{3}$. Muschel-kalk, Wurtemburg ........ 93

3. Ammonites planulatus, Sby. $\frac{1}{2}$. Chalk-marl, Sussex ... ......... 94

4. — rhotomagensis, Brongn. $\frac{1}{2}$. Chalk-marl, Sussex ..... 94

5. — Jason, Reinecke. $\frac{1}{2}$. Oxford clay, Chippenham........ 94

6. $\longrightarrow$ bifrons, Brug. $\frac{1}{4}$. Lias, Whitby $\ldots . \ldots \ldots \ldots \ldots \ldots \ldots . . . .64$

7. bisulcatus, Brug. $\frac{1}{4}$. Lias, Lyme Regis.............. 94

8. Crioceras cristatum, Orb. $\frac{2}{3}$. Gault, S. France ................ 95

9. Scaphites æqualis, Sby. $\frac{2}{3}$. Chalk-marl, Sussex ................ 95

10. Ancyloceras spinigerum, Sby. $\frac{2}{3}$. Gault, Folkstone .............. 95

11. Helicoceras rotundum, Sby. Gault, Folkestone $\quad \ldots \ldots \ldots \ldots \ldots \ldots \ldots . . \ldots 5$

12. Toxoceras annulare, Orb. $\frac{1}{4}$. Neocomian, S. France ............ 95

13. Baculites anceps, Lam. $\frac{x}{2}$. Chalk, France ................... 97

14. Ptychoceras Emericianum, Orb. $\frac{2}{3}$. Neocomian, S. France $\ldots . . .96$

15. Hamites attenuatus, Sby. $\frac{1}{3}$. Gault, Folkstone ................ 96

16. Turrilites costatus, Lam. $\frac{1}{3}$. Chalk-marl, Sussex .............. 96 
PLATE IV.

Strombida.

1. Strombus pugilis, L. $\frac{1}{2}$. W. Indies

PAGE

2. Bartonensis, Sby. Eocene, Hants.

105

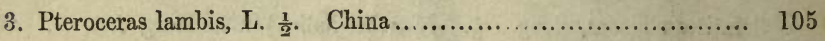

4. Rostellaria curta, Sby. $\frac{1}{3}$. Kurachee ...................... 105

5. Seraphs terebellum, L. $\frac{2}{3}$. China ........................ 106

6. Struthiolaria straminea, Gm. $\frac{1}{2}$. New Zealand ................ 130

7. Aporrhais pes-pelecani. L. $\frac{2}{3}$. Britain ...................... 129

\section{Muricida.}

8. Murex haustellum, L. $\frac{1}{2}$. China........................... 106

9. —— tenuispina, Lam. $\frac{1}{2}$. Moluccas ........................ 106

10. - palma-rosæ, Lam. $\frac{1}{3}$. Ceylon ..................... 106

10.*- erinaceus, L. (operculum). Britain ................... 106

11. Typhis pungens, Soland. Eocene, Barton .................... 106

12. Ranella granifera, Lam. $\frac{2}{3}$. N. Australia ................... 107

13. Triton tritonis, L. $\frac{1}{6}$. New Guinea-Pacific ................. 107

14. Pisania striata, Gm. sp. Mediterranean ..................... 107

15. - (Enzina) turbinella, Kiener. W. Indies ............... 107

16. Trophon Magellanicus, Gm. $\frac{1}{2}$. Tierra-del-fuego .............. 109 




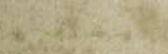

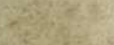

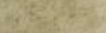

(5)

I?

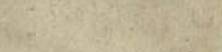

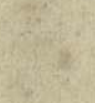

$4=$

$$
y^{3} x^{3}=2
$$

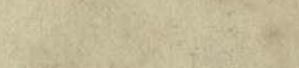

24
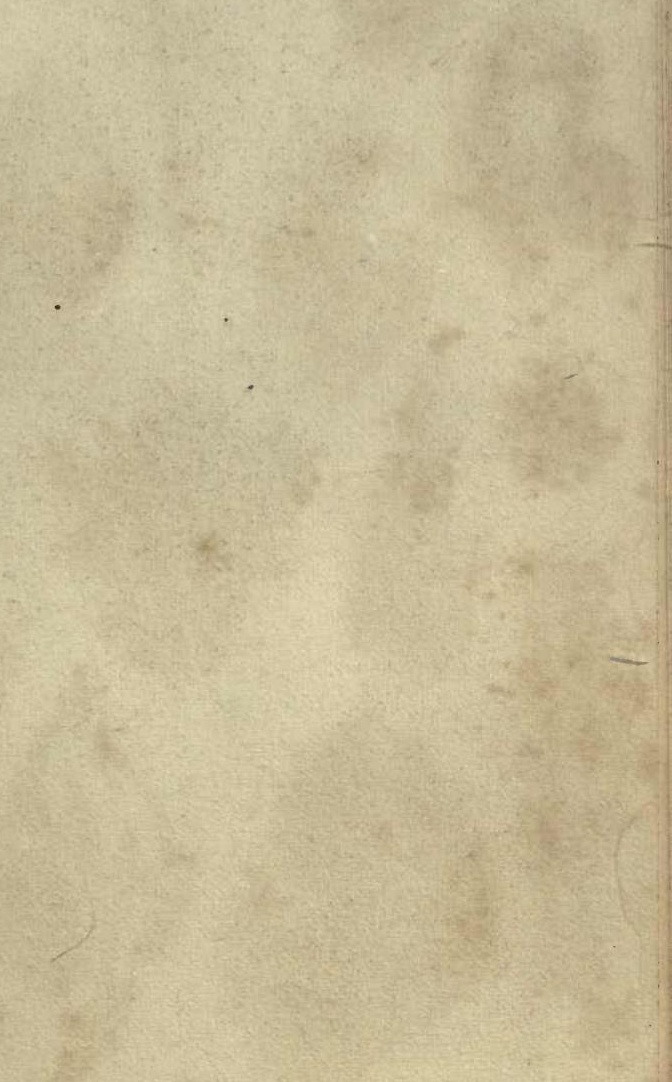


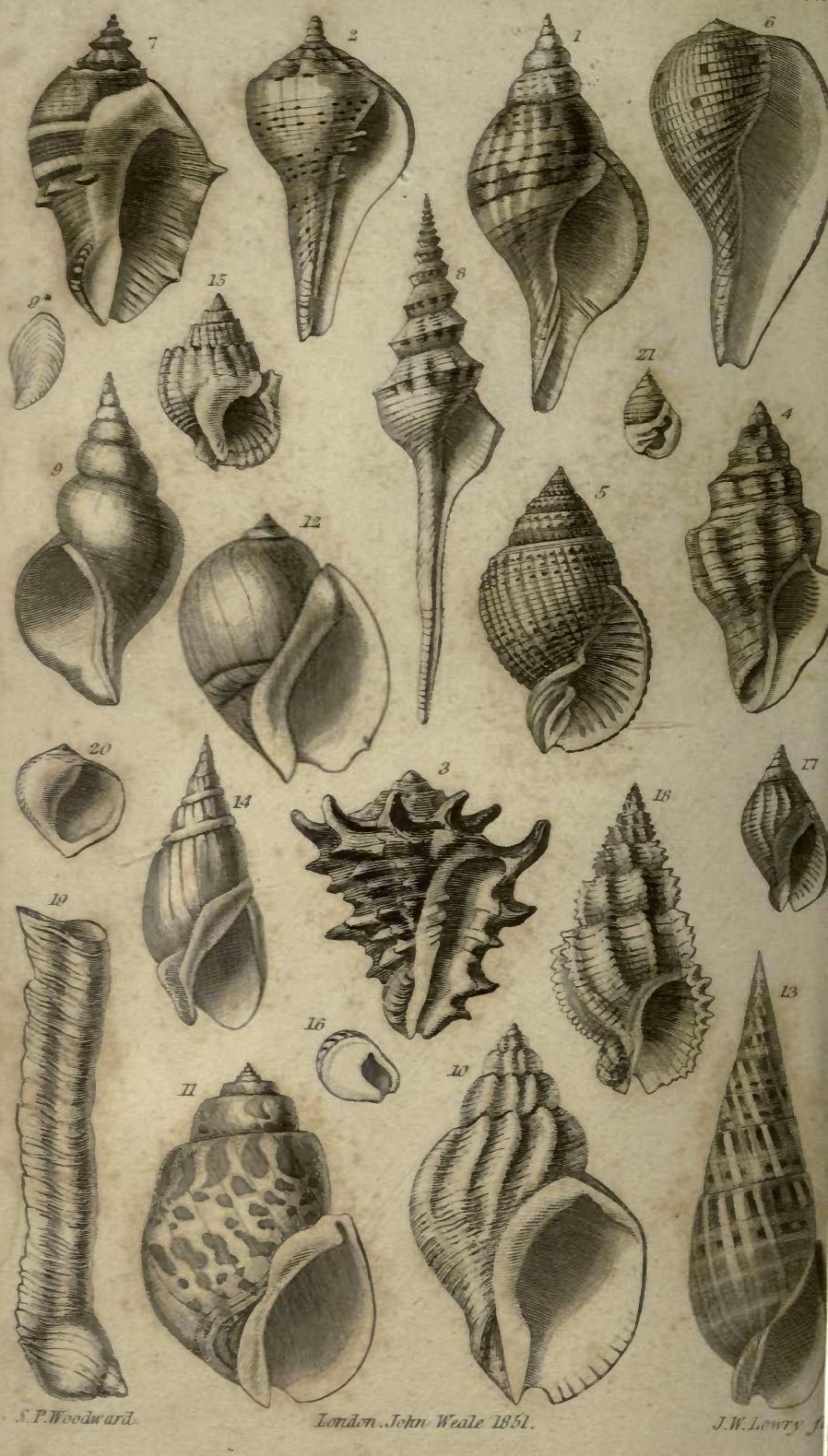




\section{PLATE V.}

\section{Muricida.}

1. Fasciolaria tulipa, L. $\frac{1}{2}$. W. Indies

2. Turbinella pyrum, L. $\frac{1}{3}$. Ceylon …......................... 108

3. - (Cynodonta) cornigera, Lam. $\frac{1}{2}$. Molnecas ........... 108

4. - (Latirus) gilbula, Gm. sp. $\frac{1}{2}$. Anstralia .............. 108

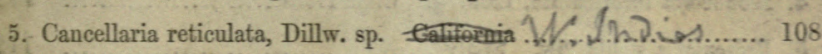

6. Pyrula retienlata, Lam. $\frac{1}{2}$. China ............................. 109

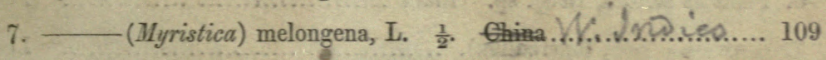

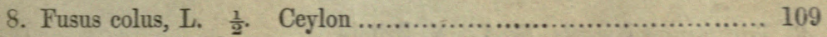
9. - (Chrysodomus) antiquus, Müll. (var. contrarius, Sby.) Red 9*-_— (operculum).

\section{Bucinida.}

10. Buecinum undatum, I. $\frac{1}{2}$. Britain.......................... 110

11. Eburna spirata, L. sp. $\frac{2}{3}$. Ceylon ........................... 111

12. Pseudoliva plumbea, Chemn. sp. $\frac{2}{3}$. W. America ................ 111

13. Terebra maculata, L. sp. $\frac{1}{2}$. Moluceas ....................... 111

14. - (Bullia) semiplicata, Gray. S. Africa ..................... 111

15. Nassa arcularia, L. sp. ‘ $\frac{2}{3}$. Moluecas ......................... 112

16. - - (Cyclonassa $)$ neritea, L. sp. Mediterranean.................. 112

17. - Cyllene) Oweni, Gray. E. Africa ....................... 112

18. Phos senticosus, L. sp. $\frac{2}{3}$. N. Australia ........................ 112

19. Magilus antiquus, Montf. $\frac{1}{2}$. Red Sea …...................... 114

20. — do. young. (Leptoconchus) ............................... 114

21. ? Ringieula ringens, Lam. $\frac{2}{1}$. Eocene, Paris .................... 112 
PLATE VI.

\section{Buccinida.}

PAGE

1. Purpura persica, L. sp. $\frac{1}{3}$. India …............................. 113

2. ___ lapillus, L. sp. (operculum.) Britain …................ 113

3. - (Concholepas) peruviana, Lam. $\frac{1}{2}$. 'Peru ……......... 113

4. Monoceros imbricatum, Lam. $\frac{2}{3}$. Cape Horn........................ ] I 3

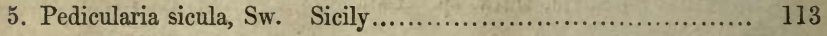

6. Planaxis sulcata, Brug. sp. India ............................ 114

7. $\longrightarrow$, (operculum). .................................... 114

8. Trichotropis borealis, Brod. N: Britain ......................... 108

9. Ricinula arachnoïdes, Lam. China............................... 114

10. Columbella mereatoria, Gmel. sp. W. Indies.................... 116

11. Harpa ventricosa, Lam. $\frac{1}{2}$. Mauritius …..................... 116

12. Dolium galea, I. sp. $\frac{1}{3}$... Mediterranean......................... 115

13. Cassidaria echinophora, L. $\frac{1}{2}, \ldots$ Medit............................... 115

14. Cassis flammea, L. China ....................................... 114

15. Oniscia cancellata, Sby. China …............................... 114

16. Oliva porphyria, L. $\frac{1}{2}$. Panama..................................... 116

17. — (Agaronia) hiatula, Gm. sp. $\frac{2}{3}$. W. Africa …........... 117

18. - (Scaphula) utriculus, Gm. sp. $\frac{2}{3}$. Africa …............... 117

19. — (Olivella) jaspidea, Gm. sp. W. Indies.................... 117

20. Ancillaria buccinoïdes, Lam. $\frac{2}{3}$. Eocene, Isle of Wight........... 117

21. — glabrata, L. sp. $\frac{1}{2}$. W. Indies 


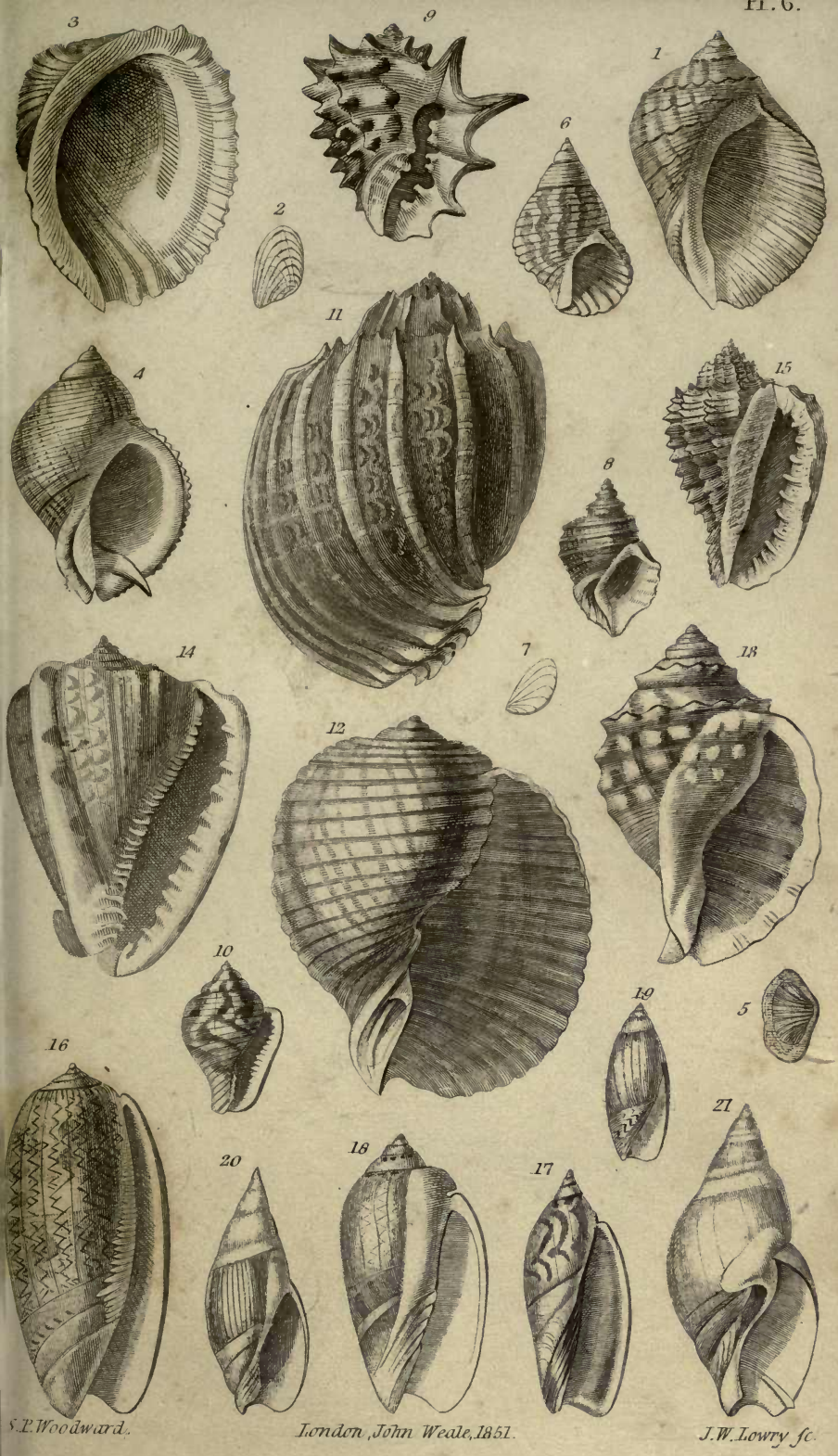





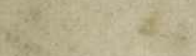

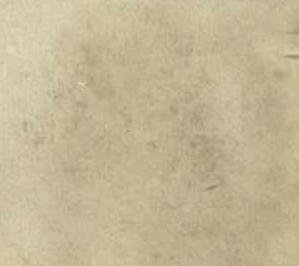




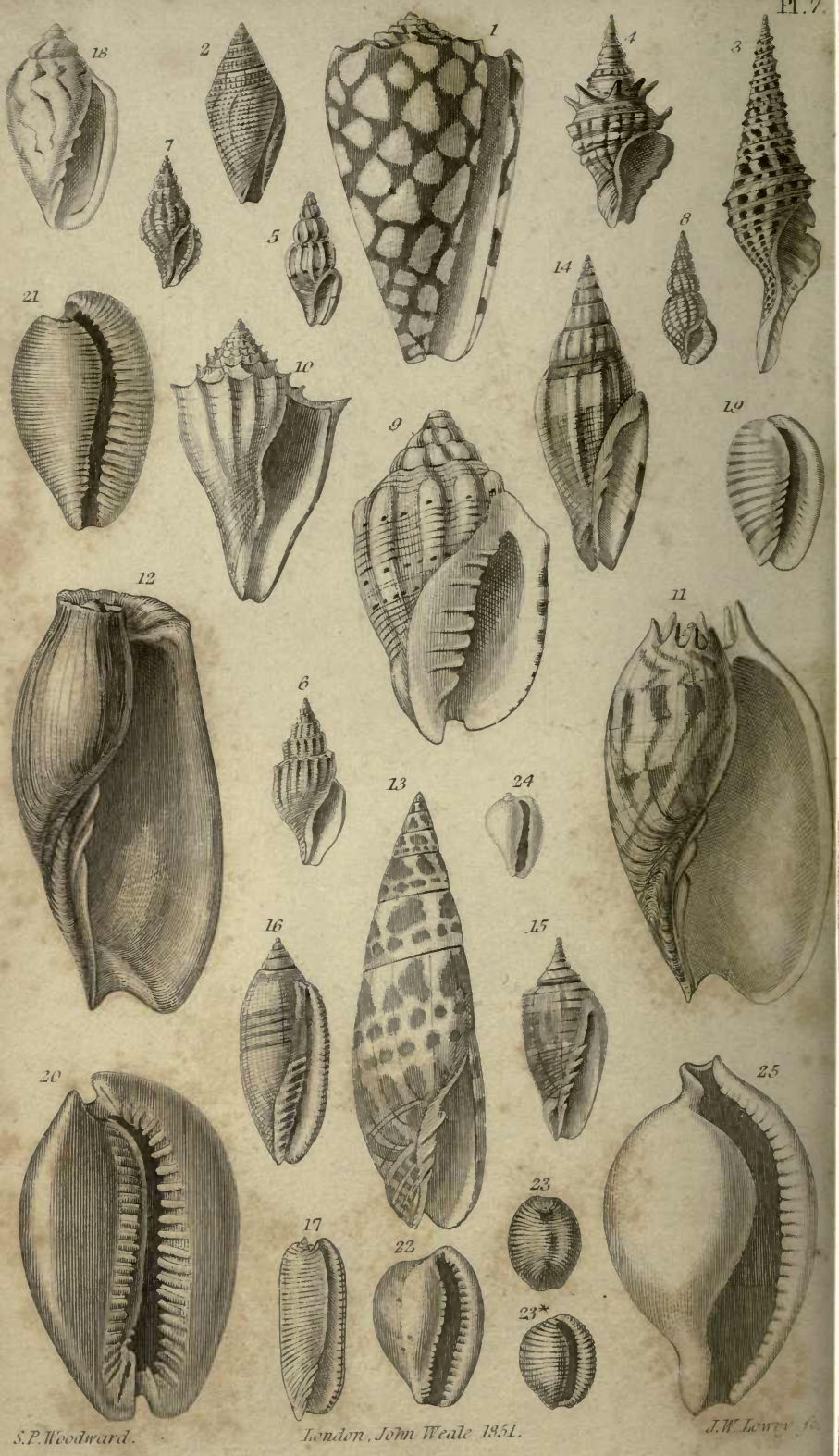




\section{PLATE VII.}

\section{Conida.}

1. Conus marmoreus $\mathrm{Gm}$. $\frac{2}{3}$. China

2. - (Conorbis) dormitor, Solander. Eocene, Barton

3. Pleurotoma Babylonica, L. sp. $\frac{2}{3}$. China

4. Clavatula mitra, Gray. W. Africa

5. Mangelia taenïata, Desh. $\frac{2}{1}$. Mediterranean

\section{Volutida.}

9. Voluta musica, L. $\frac{1}{2}$. W. Indies.......................... 119

10. Volutilithes spinosus, L. sp. $\frac{2}{3}$. Eocene, Barton _.............. 119

11. Melo diadema, Lam. sp. $\frac{1}{3}$. New Guinea ................... 119

12. Cymba proboscidalis, Lam. sp. $\frac{1}{4}$. W. Africa.................. 119

13. Mitra episcopalis, D'Arg. $\frac{1}{2}$. Ceylon …................. 119

14. — vulpecula, L. $\frac{2}{3}$. Singapore ….................... 120

15. (Imbricaria) conica, Schum. Prithes JAhi fin...... 120

16. - (Cylindra $)$ crenulata, Chemn. China .................. 120

17. Volvaria bulloïdes, Lam.' Eocene, Grignon …............. 120

18. Marginella nubeculata, Lam. $\frac{2}{3}$. W. Africa................... 120

19. (Persicula) lineata, Lam. W. Africa................. 120

\section{Cypraida.}

20. Cypræa Mauritiana, L. $\frac{1}{2}$. Inảia-Pacific..................... 121

21. - (Cyprovula $)$ capensis. Gray. $\frac{2}{3}$. S. Africa $\ldots \ldots \ldots \ldots . . . . .121$

22. - (Luponia) algoënsis, Gray. S, Africa ................ 121

23, 23* - (Trivia) europæa, Mont. Britain ................ 122

24. Erato lævis, Donovan. Britain ............................. 122

25. Ovulum ovum, L. sp. $\frac{1}{2}$. New Guinea ...................... 122 


\section{PLATE VIII.}

Naticida.

PAGE

1. Natica canrena, L. sp. $\frac{2}{3}$. China ......................... 123

2. - (Globulus) sigaretina, Lam. $\frac{2}{3}$. Eocene, Paris ............ 123

3. - (Cernina) fluctuata. Sby. $\frac{1}{2}$. Philippines ............... 123

4. Sigaretus haliotoides, L. sp. $\frac{2}{3}$. W. Indies.................... 124

5. — (Naticina) papilla, Chemn. sp. Africa.................. 124

6. Lamellaria perspicua, Mont. Mediterranean.................... 124

7. Velutina lævigata, L. sp. Britain.......................... 124

8. Narica cancellata, Chemn. sp. Pacific ......................... 124

9. Neritopsis radula, L. sp. Sandwich Islands ..................... 141

Pyramidellida.

10. Pyramidella auris-cati, Chemn. sp. Mauritius ................... 125

11. (Obeliscus) dolabrata, Gmel. sp. W. Indies .......... 125

12. Odostomia plicata, Mont. sp. $\frac{2}{1}$. Britain ................... 125

13. Chemnitzia elegantissima, Mont. sp. $\frac{2}{1}$. Weymouth ........... 126

14. Eulima polita, L. Britain .................................. 126

15. Stylifer astericola, Brod. Philippines ......................... 126

\section{Cerithida.}

16, 16*. Cerithium nodulosum, Brug. $\frac{1}{2}$. Moluccas................. 127

17. (Bittium) reticulatum, Da Costa. Britain........ 127

18. Triphoris perversus, L. sp. Mediterranean ..................... 128

19. Potamides mixtus, Defr. Eocene, Paris ...................... 128

20. - (Pyrazus) palustris, Brug. $\frac{1}{2}$. India................. 128

21. - (Terebralia) telescopium, Brug. $\frac{1}{2}$. India............. 128

22. (Pirenella) mammillatus, Risso sp. Mediterranear...... 128

23. - (Lampania) zonalis, Gray. Chusan .................... 128

24. (Cerithidea) decollatus, L. sp. Cape ................. 128

\section{Melaniada.}

25, 25* Melania amarula, L. sp. $\frac{2}{3}$. Madagascar .................. 131

26. (Melanatria) fluminca, Gm. sp. $\frac{1}{2}$. Madagascar...... 131

27. - (Melafusus) fluviatilis, Say. $\frac{2}{3}$. U. States ........... 131

28. - (Anculotus) præmorsa, Say. U. States ............. 131

29. (Tibex) fuscata, Gm. sp. Africa ..................... 131

30. Melanopsis costata, Fér. Syria............................... 132

81. $-($ Pirena $)$ atra. L. sp. $\frac{2}{3}$. Ceylon..................... 132 


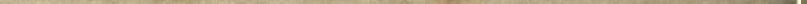





\section{PLATE IX.}

\section{Turritellida.}

PAGE

1. Turritella, imbricata, L, W. Indies 132

2. (Mesalia) sulcata, var. Lam. Eocene, Paris. 132

3. (Proto) cathedralis; Brongn. . $\frac{1}{2}$. Miocene, Bordeaux... 132

4. Aclis perforatus, Mont. sp.

5. Cæcum trachea, Mont. $\frac{4}{1}$. Britain 132

6. - (fry, magnufied $\frac{8}{1}$.)

7. Vermetus lumbricalis, Gm. sp. (young.) W. Africa 133

8. Siliquaria anguina, L. sp. $\frac{1}{2}$. New Guinea

9. Scalaria pretiosa, Lam.

\section{Litorinida.}

10. Litorina litorea, L. Britain

11. - (Tectaria) pagodus, L. $\frac{1}{2}$. Zanzibar ..................... 133

12. - - (Fossarus) sulcatus, S. Wood. Mediterranean ............ 135

13. (Modulus) tectum, Gm. sp. N. Australia ................. 135

14. - (Risella) nana, Lam. sp. $\frac{2}{3}$. Tasmania .................. 135

15. Solarium perspectivum, L. sp. $\frac{2}{3}$. China .................... 135

16. Lacuna pallidula, Da Costa. Britain .............................. 136

17. Rissoa labiosa, Mont. Britain ............................. 136

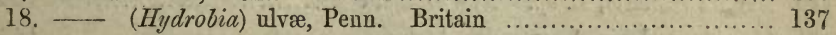

19. _ _ (Jeffreysia) diaphana, Alder. (Operculum) Britain .......... 137

20. — (Skenea) planorbis, O. Fabr. ( $\frac{1}{16}$ inch). Britain........... 137

21. Nematura delta, Bens. $\frac{2}{1}$. India............................... 137

22. Lithoglyphus fuscus, Pfr. sp. Danube ....................... 138

23. Amnicola isogona, Say. U. States................................ 131

24. Litiopa bombix, Kiener. Mediterranean ….................. 136

25. Truncatella subtruncata, Mont. sp. $\frac{2}{1}$. Mediterranean.............. 137

\section{Paludinida.}

26. Paludina Listeri, Hanley. $\frac{1}{2}$. Norwich ...................... 138

27. — (Bithinia) tentaculata, Mont. Norwich................. 138

28. Valvata piscinalis, Müll. Norwich........................... 140

29. — cristata, Múll. Norwich.................................. 140

30. Ampullaria globosa, Sw. $\frac{1}{2}$. India ......................... 138

31. - (Marisa) cornu-arietis, L. sp. Brazil .................... 139

32. - (Lanistes) Bolteniana, Chemn. sp. $\frac{1}{2}$. Nile .......... 139

33. Amphibola avellana, Chemn. sp. New Zealand.................... 139

34. Paludomus aculeatus, Gm. sp. Ceylon ......................... 131

Neritida.

35. Nerita ustulata, L. Scinde .................................. 141

36. - (Velates) perversus, Gm. sp. Eocene, Soissons ............. 141

37, 38. Pileolus plicatus, J. Sby. Bath oolite, Ancliff ............... 141.

39. Neritina zebra, Brug. Pacific ............................. 141

40. — crepidularia. Less. India............................... 142

41. Navicella porcellana, Chemn. sp. Mauritius-Pacific ............ 142 


\section{PLATE $\mathrm{X}$.}

1. Phorus corrugatus, Reeve. $\frac{1}{2}$. Kurachee, India

PA'GE

135

\section{Turbinida.}

2. Turbo marmoratus, L. $\frac{1}{4}$. China $\ldots \ldots \ldots \ldots \ldots \ldots \ldots \ldots \ldots \ldots \ldots \ldots \ldots \ldots \ldots \ldots \ldots \ldots \ldots$

3. Phasianella anstralis, Gm. sp. $\frac{2}{3}$. New Zealand .................... 143

4. Imperator imperialis, Chemn. sp. $\frac{1}{2}$. New Zealand ............. 143

5. Trochus niloticus, L. $\frac{1}{4}$. China ….................................. 143

6. - (Pyramis) obeliseus, Gm. sp. China.................... 144

7. - (Margarita) helicinus, O. Fabr. Britain …............. 144

8. - (Elenchus) iris, Chemn. New Zealand ................... 144

9. - (Bankivia) varians, Gray. New Zealand ................ 144

10. Rotella vestiaria, L. sp. New Zealand ........................... 144

11. Monodonta labio, L. sp. W. Africa …......................... 144

12. - (Clanculus) Pharaonis, L. sp. Red Sea............... 144

13. Delphinula laciniata, Lam. China ................................. 144

14. - (Liotia) Gervillii, Defr. Eocene, Sussex ............. 145

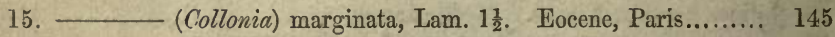

16. - (Cyclostrema) cancellata, Marryatt. Philippines ..... 145

17. Adeorbis sub-carinata, Mont. sp. Britain ....................... 145

18. Euomphalus pentangulatus. Sby. $\frac{1}{2}$. Carb: limestone, Ireland ... 145

19. Stomatella imbricata, Lam. India ............................... 145

20. - (Broderipia) rosea, Brod. $\frac{2}{1}$. S. Seas................... 146

\section{Haliotida.}

21. Haliotis tuberculata, L. Guernsey .............................. 146

22. Stomatia phymotis, Helblin. Java ............................... 147

23. Scissurella crispata, Fleming. $\frac{4}{1}$. Britain ........................ 147

24. Pleurotomaria Anglica, Sby. $\frac{1}{2}$. Lias, Gloucester …........... 147

25. Murchisonia bilineata, D'Arch. Devonian, Eifel ................ 147

26. Trochotoma conuloides, Desl. Bath Oolite, Stroud ............. 148

27. Ianthina fragilis, Lam. $\frac{2}{3}$. W. Indies …..................... 148 


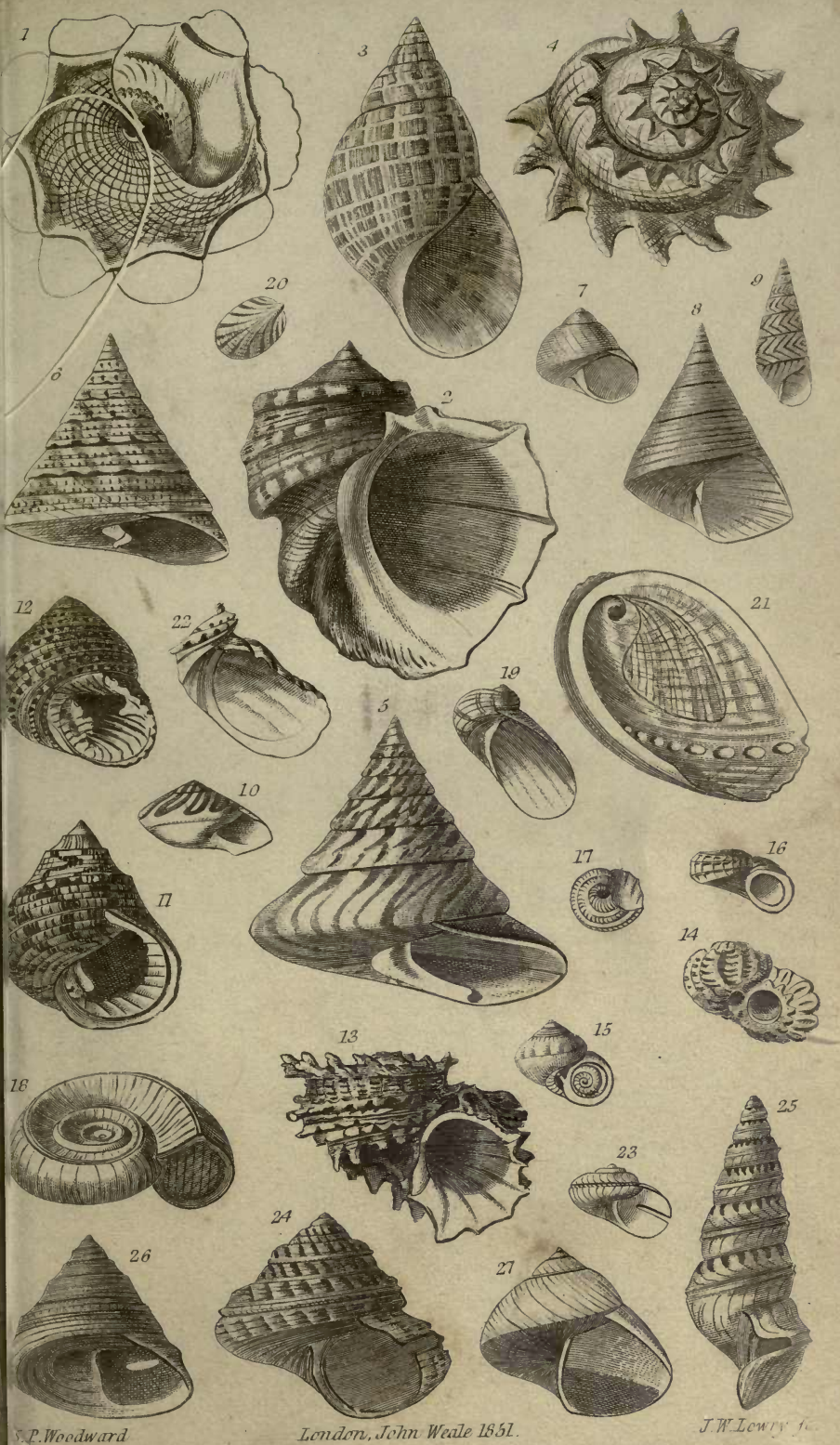






\section{PLATE XI.}

\section{Fissurellida.}

1. Fissurella Listeri, Orb. W. Indies ........................... 149

2. macroschisma, Humphr. Philippines ............... 150

3. Puncturella Noachina, L. sp. N. Britain ..................... 150

4. Rimula Blainvillii, Defr. Philippines........................ 150

5, 6. Emarginula reticulata, Sby. Britain ....................... 150

7, 8. - (Hemitoma) rugosa, Quoy. Tasmania .............. 151

9. Parmophorus australis, BI. $\frac{1}{2}$. New Zealand ................... 151

\section{Calyptraida.}

10. Calyptræa equestris, L. sp. Philippines ...................... 151

11. Dillwynnii, Gray. W. Indies...................... 151

12. - (Crucibulum) rudis, Brod. W. America............... 152

13, 14. — (Trochita) radians, Lam. W. America .............. 152

15, 15.*_ Sinensis, L. Britain.................... 152

16. Crepidula fornicata, L. sp. W. Indies........................ 152

17. Pileopsis Hungaricus, L. $\frac{2}{3}$. Torbay .......................... 152

18. — militaris, L. W. Indies............................ 152

19. - (Amathina) tricarinata, Gray. $\frac{2}{3}$. India ............... 153

20. Hipponyx cornucopiæ, Defr. $\frac{1}{3}$. Eocene, Paris................ 153 21. - (shelly base).

\section{Patellida.}

22. Patella longicosta, Lam. $\frac{2}{3}$. W. Indies ..................... 154

23. - (Nacella $)$ pellucida, L. Britain........................ 155

24. Acmæa testudinalis, Müll. sp. Britain ....................... 155

25. Siphonaria sp. Kurachee, India ............................ 155

26. Gadinia peruviana, Gray. Peru ........................... 155

\section{Dentatiada.}

27. Dentalium elephantinum, L. $\frac{1}{2}$. Red Sea .................... 156

\section{Chitonida.}

28. Chiton squamosus, I. $\frac{1}{2}$. W. Indies ........................ 156

29. - (Acanthopteura) spinosus, Brug. N. Australia............ 157

30. — (Acanthochites) fascicularis, I. Britain ................. 157

31. — (Chitonellus) fasciatus, Quoy. $\frac{1}{3}$. Philippines ............ 157 


\section{PIATE XII.}

Helicida.

1. Helix (Acavus) hæmastoma, L. $\frac{2}{3}$ Ceylon.

2. - (Polygyra) polygyrata, Born. $\frac{1}{2}$. Brazil.

3. - (Carocolla) lapicida, L. Britain.

4. - (Anastoma) globulosa, Lam. Brazil.

5. - (Tridopsis) hirsuta, Sby. U. States.

6. - (Streptaxis) contusa, Fér. Brazil.

7. - (Sagda) epistylium, Müll. Jamaica.

8. - - (Helicella) cellaria, Müll. Britain.

9. - (Stenopus) lævipes, Müll. Malabar.

10. Bulimus oblongus, Müll. $\frac{1}{2}$. Guiana.

11,12 - decollatus, L. S. Europe.

13. - (Partula) faba, Martyn. Anstralian Islands f cu hy

14. - (Zua) lubricus, Müll. Britain.

15. - (Azeca) tridens, Pulteney. Britain.

16. Pupa uva, L. sp. Guadaloupe.

17. - (Vertigo) Venetzii, Charp. $\frac{5}{1}$. Pliocene, Essex.

18. Megaspira elatior, Spix sp. $\frac{2}{3}$. Brazil.

19. Clausilia plicatula, Drap. . Kent.

20. Cylindrella cylindrus, Chemn. sp. $\frac{2}{3}$. Jamaica.

21. Balæa perversa, 1. sp. Britain.

22. Achatina variegata, Fab. Col. $\frac{1}{2}$. W. Africa.

23. Succinea putris, L. Britain.

24. - (Omalony $x)$ unguis, Orb. Paraguay.

\section{Limacida.}

25. Limax maximus, I. Britain.

26. Testacella haliotoides, Fèr. $\frac{2}{1}$. Britain.

27. Parmacella (Cryptella) cslyculata, Sby. . Canaries.

28. Vitrina Draparnaldi, Cuv. Britain.

29. - (Daudebardia) brevipes, Drap. $\frac{2}{1}$. Austria.

\section{Limneide.}

30. Limnea stagnalis, L. sp. Britain.

31. - (Amphipeplea) glutinosa, Müll. Britain.

32. Physa fontinalis, Mont. sp. Britain.

33. Ancylus fluviatilis, Lister sp. Britain.

34. Planorbis corneus, L. sp. Britain.

\section{Auriculida.}

35. Auricula Judæ. L. $\frac{2}{3}$. India.

36. — scarabæus, Gm. sp. Ceylon.

37. - (Conovulus) coffea, L. W. Indies.

38. (Alexia) de ticulata, Mont. sp. Britain.

39. Carychium minimum, Drap. sp. $\frac{5}{1}$. Britain.

\section{Cyclostomida.}

40. Cyclostoma elegans, Müll. sp. Britain.

41. Cyclophorus involvulus, Müll. sp. $\frac{2}{3}$. India.

42. Pupina bi-canaliculata, Sby. N. Australia.

43. Helicına Brownii, Sby. Philippines.

44. Acicula fusca, Walker, sp. $\frac{4}{1} \cdot$ Britain, 


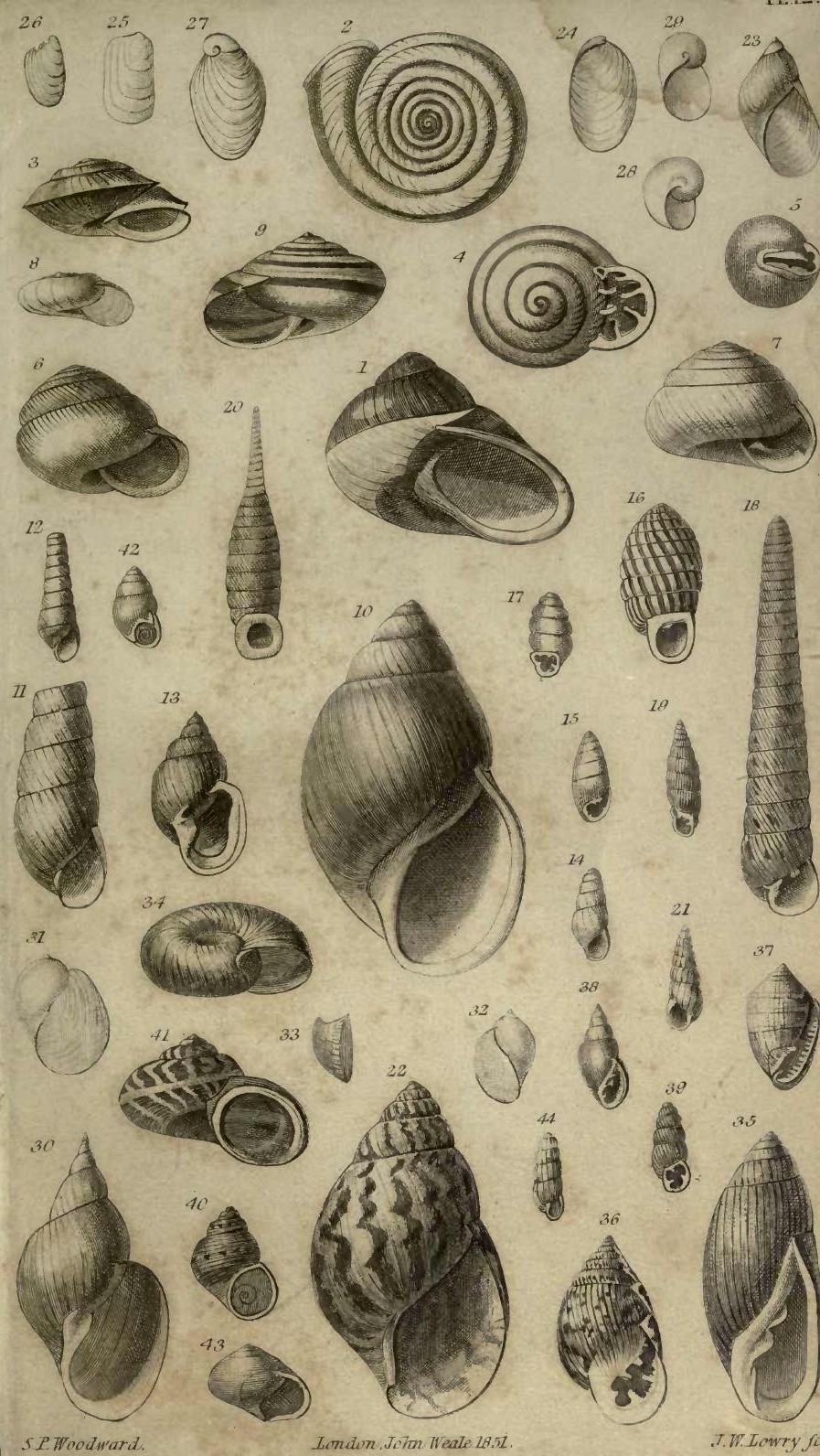




RETURN TO the circulation desk of any

University of California Library

or to the

NORTHERN REGIONAL LIBRARY FACILITY Bldg. 400, Richmond Field Station University of California Richmond, CA 94804-4698

ALL BOOKS MAY BE RECALLED AFTER 7 DAYS 2-month loans may be renewed by calling (415) 642-6233

1-year loans may be recharged by bringing books to NRLF

Renewals and recharges may be made 4 days prior to due date

DUE AS STAMPED BELOW 
